\title{
Carriere-ontwikkeling: de overgang van opleiding naar arbeidsmarkt
}

Citation for published version (APA):

Schreurs, M. L. J. J. (1996). Carriere-ontwikkeling: de overgang van opleiding naar arbeidsmarkt. [Doctoral Thesis, Maastricht University]. Rijksuniversiteit Limburg.

https://doi.org/10.26481/dis.19960628ms

Document status and date:

Published: 01/01/1996

DOI:

10.26481/dis.19960628ms

Document Version:

Publisher's PDF, also known as Version of record

\section{Please check the document version of this publication:}

- A submitted manuscript is the version of the article upon submission and before peer-review. There can be important differences between the submitted version and the official published version of record.

People interested in the research are advised to contact the author for the final version of the publication, or visit the DOI to the publisher's website.

- The final author version and the galley proof are versions of the publication after peer review.

- The final published version features the final layout of the paper including the volume, issue and page numbers.

Link to publication

\footnotetext{
General rights rights.

- You may freely distribute the URL identifying the publication in the public portal. please follow below link for the End User Agreement:

www.umlib.nl/taverne-license

Take down policy

If you believe that this document breaches copyright please contact us at:

repository@maastrichtuniversity.nl

providing details and we will investigate your claim.
}

Copyright and moral rights for the publications made accessible in the public portal are retained by the authors and/or other copyright owners and it is a condition of accessing publications that users recognise and abide by the legal requirements associated with these

- Users may download and print one copy of any publication from the public portal for the purpose of private study or research.

- You may not further distribute the material or use it for any profit-making activity or commercial gain

If the publication is distributed under the terms of Article $25 \mathrm{fa}$ of the Dutch Copyright Act, indicated by the "Taverne" license above, 
Carrière-ontwikkeling:

de overgang van opleiding naar arbeidsmarkt 



\section{Carrière-ontwikkeling: \\ de overgang van opleiding naar arbeidsmarkt}

\section{Proefschrift}

ter verkrijging van de graad van doctor aan de Rijksuniversiteit Limburg te Maastricht, op gezag van de Rector Magnificus, Prof.mr. M.J. Cohen, volgens het besluit van het College van Dekanen, in het openbaar te verdedigen op vrijdag 28 juni 1996 om 16.00 uur

door

Marie-Louise J.J. Schreurs 


\section{Promotores:}

Prof.dr. H.G. Schmidt

Prof.dr. F.J.N. Nijhuis

\section{Beoordelingscommissie:}

Prof.dr. F.C.B. van Wijmen (voorzitter)

Prof.dr. J.A.M. Heijke

mw. dr. G. Noordenbos

Prof.dr. Ch.J. de Wolff (Katholieke Universiteit Nijmegen)

Prof.dr. W.H.F.W. Wijnen 


\section{Inhoudsopgave}

Inleiding 1

1. Probleemstelling 1

2. Toespitsing van de probleemstelling 2

3. Opbouw van het proefschrift $\quad 4$

1. Invalshoeken van carrière-studies $\quad 7$

1. Theoretische achtergrond van het begrip carrière 7

2. De ontwikkelingsbenadering 9

3. Vrouwen en carrière $\quad 13$

4. Overgangscyclus van Nicholson en West 16

5. Succes in de carrière $\quad 21$

6. De rol van de opleiding 23

2. Carrière-ontwikkeling van studenten 25

1. Voorbereiding 26

2. Verwerven van een baan 30

3. Eerste werkervaringen 33

4. Succes ervaren 36

5. Onderzoeksvragen 38

3. Opzet van het onderzoek $\quad 41$

1. Eerste deelonderzoek: de loopbaan-enquête 41

2. Tweede deelonderzoek: vragenlijsten en psychologische tests 44

3. Derde deelonderzoek: het carrière-interview 46

4. Vierde deelonderzoek: vergelijking van PGO met traditioneel
onderwijs

5. Samenvatting 49

4. Voorbereidingsfase $\quad 51$

1. Variabelen uit de voorbereidingsfase $\quad 52$

2. Kenmerken van de voorbereidingsfase $\quad 54$

3. Relaties tussen kennis van de arbeidsmarkt, doelgerichtheid, persoonlijkheidskenmerken, persoonlijke situaties en $\begin{array}{ll}\text { sollicitatiegedrag } & 60\end{array}$

4. Causale modellering van de voorbereidingsfase 63

5. Discussie 65 
1. Variabelen uit de fase van baan verwerven 70

2. Kenmerken van de fase van baan verwerven 71

3. Relaties tussen arbeidsmarktgerichtheid, sollicitatievaardigheden, persoonlijkheidsaspecten en het hebben van een baan

4. Causale modellering van de fase van het verwerven van een baan 79

5. Discussie

6. Eerste werkervaringen

1. Variabelen uit de fase van de eerste werkervaringen 84

2. Kenmerken van de fase van de eerste werkervaringen 86

3. Relaties tussen cognities, omgevingskenmerken, overgangskenmerken, functiekenmerken en waardering van de werksituatie 96

4. Causale modellering van de fase van de eerste werkervaringen 99

5. Discussie 100

7. Ervaren van succes

1. Variabelen uit de fase van succes ervaren 104

2. Kenmerken van de fase van succes 105

3. Relaties tussen functiekenmerken, zelfmanagement, loopbaankenmerken, opleidingsaspecten en het ervaren van succes 110

4. Causale modellering van de fase van het ervaren van succes 112

5. Discussie

8. Aansluiting van opleiding op werksituatie

1. Verwachte en feitelijke relevantie van de opleiding

2. Vergelijking tussen studenten in een PGO-curriculum en een traditioneel curriculum

3. Discussie

9. De overgang van opleiding naar arbeidsmarkt, samenvatting, discussie en conclusies

1. Samenvatting

2. Het overgangsproces nader beschouwd

3. De overgang van opleiding naar arbeidsmarkt in carrièretheoretisch perpectief

4. Verschillen tussen mannen en vrouwen in het overgangsproces

5 . De rol van de opleiding in het overgangsproces

Summary

Literatuur

Bijlage 


\section{Voorwoord}

Dit proefschrift is tot stand gekomen met de hulp van velen. Een aantal personen wil ik graag op deze plaats bedanken.

Mijn promotores Henk Schmidt en Frans Nijhuis bedank ik voor hun waardevolle adviezen in de verschillende fasen van het onderzoek en voor de bruikbare feedback op eerdere versies van dit boek. Ik heb veel van hen geleerd. De leden van de beoordelingscommissie wil ik bedanken voor hun suggesties om het manuscript te verbeteren.

Ariadne Rook, Sandra Gransier en Charlotte van Zon zijn als student-assistenten betrokken geweest bij het onderzoek. Ik bedank hen voor hun inzet en betrokkenheid.

Ik ben Petry Thiemann erkentelijk voor het verzorgen van de lay-out. Haar adviezen over punten en hoofdletters heb ik opgevolgd, waardoor de puntjes op de i staan.

Angel Waajen vertaalde de samenvatting en Bert Kerkhofs maakte de figuren, waarvoor ik hen dank.

Jeanine Schreurs corrigeerde de tekst op hinderlijke zinsconstructies en spelfouten. Ik bedank haar voor alle adviezen en betrokkenheid.

Francy van der Heijden heeft mij ondersteund door taken over te nemen en door te luisteren naar alle promotieperikelen. Ik wil haar hiervoor bedanken. Verder wil ik Tessa van Mourik en Geke Blok bedanken voor hun stimulerende belangstelling.

Collega's van de vakgroep Onderwijsontwikkeling en Onderwijsresearch waren op velerlei wijze behulpzaam. Bij enkelen liep ik binnen met vragen over statistiek; anderen waren stimulerend in het volgen van de voortgang. I $k$ bedank hen hartelijk hiervoor.

Tot slot wil ik mijn gezin noemen. Peter Nelissen dank ik voor zijn ondersteuning en voor het mooie omslagontwerp. Onze kinderen Sophie, Izaak en Irene bedank ik met een dikke kus omdat zij alles over carrières zo goed relativeren.

Marie-Louise Schreurs

april 1996 



\section{Inleiding}

\section{Probleemstelling}

Het overgangsproces van opleiding naar arbeidsmarkt is een cruciale fase in de ontwikkeling van een loopbaan. Het belang van dit overgangsproces wordt meestal niet onderkend. Tijdens de opleiding ligt het accent op kennisverwerving en studieprestaties en niet of nauwelijks op arbeidsmarktoriëntatie en loopbaanplanning. Studenten zijn gericht op het bestuderen van de leerstof en het halen van de tentamens. De relevantie van de literatuur voor de latere beroepsuitoefening is niet aan de orde. Na het afstuderen, of in het meest gunstige geval vlak ervoor, gaan studenten aan de slag om een baan te verwerven en betreden zij de arbeidsmarkt. We mogen verwachten dat voor het verwerven van een baan op de arbeidsmarkt een andere houding en andere vaardigheden van studenten worden vereist dan tijdens de studie van belang zijn. Aangenomen mag worden dat het diploma en de bijbehorende cijferlijst onvoldoende voorwaarde zijn om de overstap succesvol te maken. Aannemelijk moet worden gemaakt over welke kennis en vaardigheden men beschikt en wat men een werkgever heeft te bieden. Vaak wordt niet herkend door afgestudeerden dat deze andere houding is vereist. Bovendien is het moeilijk voor de afgestudeerden om zijn of haar opleiding en kwaliteiten te vergelijken met de opleiding en kwaliteiten van anderen. En verder heeft niet iedereen het van nature in zich, om zichzelf en de gevolgde opleiding goed te kunnen verkopen.

Doordat de opleiding en de entree op de arbeidsmarkt worden beschouwd als twee strikt gescheiden perioden, verloopt de overgang van de opleiding naar de arbeidsmarkt voor veel studenten cq. afgestudeerden moeizaam.

Waar blijkt dit problematische karakter uit? Studenten beginnen relatief laat aan de voorbereiding op de arbeidsmarkt. Dit lijkt een nadeel te zijn voor het vinden van een baan. De periode tussen afstuderen en de start in de eerste functie is enerverend en brengt veel onzekerheid en stress met zich mee.

Vanuit carrière-ontwikkelingsperspectief kan de overgang van de opleiding naar de arbeidsmarkt worden gezien als een doorlopend proces, waarin verschillende fasen zijn te onderscheiden. Idealiter volgen deze fasen vloeiend op elkaar. In de praktijk is dit vaak niet het geval.

In deze studie wordt gepoogd inzicht te verschaffen in de factoren die een vloeiende overgang bevorderen dan wel in de weg staan. Welke factoren bevorderen dat de overgang van de opleiding naar de arbeidsmarkt succesvol verloopt? 


\section{Toespitsing van de probleernstelling}

De duidelijke scheiding tussen opleiding en arbeidsmarkt en het feit dat de overgang vaak niet geleidelijk maar abrupt verloopt, worden als problematisch beschouwd. Het breukvlak tussen opleiding en beroepsloopbaan is vanuit carrière-theorieën gezien, onlogisch. De voorbereiding op de carrière vindt immers plaats tijdens de opleiding (Super, 1957; Miller \& Form, 1964; Schein, 1978; Lievegoed, 1991). Het lijkt erop dat studenten deze twee periodes echter als sterk verschillend ervaren. Vanwege de gerichtheid op de studie en vanwege onvoldoende besef van het belang van een goede voorbereiding, begint men relatief laat met een oriëntatie op de arbeidsmarkt. De voorbereiding verloopt dan ook grotendeels impliciet, waardoor een onnodige vertraging wordt geriskeerd. Dit probleem vormt het uitgangspunt voor dit proefschrift. In de literatuur is weinig terug te vinden over deze specifieke periode in de carrière. Ook hier is een scheiding te zien tussen de opleiding en de start in de eerste functie. Hall (1976) spreekt over de dichotomie tussen de opleidingsperiode van de carrière-ontwikkeling en de periode van de start in de eerste baan in een organisatie. Volgens hem valt het overgangsproces van de opleiding naar de arbeidsmarkt buiten de interesse van zowel de opleiding als van de organisaties. Dit verklaart waarom over deze periode zo weinig theorie is ontwikkeld. Over de startfase is een beperkte hoeveelheid onderzoek verricht. Dit is echter niet gerelateerd aan de opleiding en de voorbereiding die tijdens de opleidingsfase zou moeten plaatsvinden. De informatie die bekend is over de voorbereidingsfase is eveneens nauwelijks in verband gebracht met het functioneren op de werkplek nadat een baan is verworven.

Het problematiseren van deze fase in de carrière-ontwikkeling heeft als doel inzicht te geven in een cruciale periode in de loopbanen van studenten cq. afgestudeerden, waarbij opleiding en arbeidsmarkt niet meer uitsluitend als aparte instituties worden beschouwd, maar in elkaars verlengde kunnen worden gezien. Deze fase wordt dan ook beschouwd als een overgangsproces van opleiding naar arbeidsmarkt. Gezocht wordt naar een beschrijving van dit proces. Welke concepten zijn van belang bij het beschrijven van het overgangsproces van de opleiding naar de arbeidsmarkt? Op basis van de literatuur kunnen vijf belangrijke aspecten worden onderscheiden:

\section{Loopbanen en loopbaanfasen; ontwikkelingsbenadering van carrières.}

Welke definities zijn er in de literatuur te vinden van de begrippen loopbaan en carrière? Welke modellen zijn er beschreven van het verloop van de loopbaan in verschillende fasen? Inzicht hierin is noodzakelijk om het overgangsproces van de opleiding naar de arbeidsmarkt goed te kunnen plaatsen binnen de totale carrière.

\section{Verschillen tussen loopbanen van mannen en van vrouwen.}

Carrières van vrouwen en mannen verlopen verschillend. Oorzaken hiervan worden vaak gezocht op het persoonlijke vlak: de belangstelling en aspiraties 
van mannen en vrouwen verschillen; en op organisatorisch en structureel niveau: vrouwen ondervinden meer belemmeringen om een goede positie op de arbeidsmarkt te verwerven. In deze studie wordt bekeken of mannen en vrouwen van elkaar verschillen in het overgangsproces van de opleiding naar de arbeidsmarkt. Zijn aspiraties inderdaad verschillend? Kiezen zij verschillende strategieën om een baan te verwerven en om moeilijke situaties te hanteren in hun eerste baan.

\section{Overgangen in de loopbaan.}

Wanneer we het verloop van de carrière bestuderen, kan het accent liggen op de kernpunten van de verschillende fasen die elkaar opvolgen. Dit is meestal het geval. Zoals in de beschrijvingen van de ontwikkelingsfasen van de loopbaan die zijn aangegeven onder punt 1 . We kunnen ook het accent leggen op de overgang van de ene naar de volgende fase. Aan welke voorwaarden moet zijn voldaan om de overgang goed te kunnen maken? Zijn er algemene aspecten te ontdekken die bij elke overgang een rol speelt? Nicholson en West (1988) richten zich specifiek op overgangen in de carrière.

\section{Succes in de loopbaan.}

Wanneer is de loopbaan succesvol? Zijn hiervoor objectieve criteria aan te geven of gaat het eerder om de subjectieve beleving en waardering van de loopbaan? Soms wordt inkomen gebruikt als maat voor succes. In andere studies wordt succes beschouwd als een subjectieve waardering van het eigen functioneren, die onder bepaalde condities wordt bereikt. De aard van de functie en de wijze waarop deze wordt vervuld zijn van invloed op het ervaren van succes. Hall (1976) geeft in de succescyclus aan welke aspecten van de werksituatie leiden tot succes.

\section{De rol van de opleiding in het overgangsproces.}

Welke rol speelt de opleiding in het overgangsproces van de opleiding naar de arbeidsmarkt? Sommige opleidingen bereiden beter voor op de beroepspraktijk dan andere. Vaak wordt aangenomen dat hogere beroepsopleidingen beter aansluiten op de arbeidsmarkt dan academische opleidingen. Beroepsopleidingen zijn gericht op specifieke beroepen terwijl academische opleidingen zijn gericht op een bepaalde denkwijze. De laatste prognoses van het Researchcentrum Onderwijs en Arbeidsmarkt (ROA) laten zien dat hogere beroepsopleidingen een relatief beter arbeidsmarktperspectief hebben dan academische opleidingen (Ramaekers, 1994). Men doelt hierbij vooral op de inhoudelijke aansluiting van de opleiding op de arbeidsmarkt. Daarnaast spelen ook andere factoren een rol om de overgang goed te kunnen maken: aanpassingsvermogen aan een nieuwe situatie bijvoorbeeld, probleemoplossend vermogen en stresshantering. 


\section{Opbouw van het proefschrift}

Het overgangsproces van opleiding naar arbeidsmarkt vormt het onderwerp van dit proefschrift. Dit proces wordt opgedeeld in vier opeenvolgende periodes, waarin verschillende taken centraal staan: de voorbereidingsfase, de fase van baan verwerven, de eerste werkervaringen en de fase van het ervaren van succes. Dit vierfasen-model lag ten grondslag aan de opzet van het onderzoek. In de opbouw van dit proefschrift komt deze indeling terug.

in hoofdstuk 1 wordt een algemene inleiding gegeven over carrière-studies. Verschillende invalshoeken worden hierbij besproken en bekritiseerd vanuit het perspectief van het overgangsproces van opleiding naar arbeidsmarkt.

Hoofdstuk 2 gaat in op de carrière-ontwikkeling van studenten. Hierin wordt het vierfasen-model geïntroduceerd waarin de overgang van opleiding naar arbeidsmarkt kan worden beschreven. Het overgangsproces wordt hierbij beschouwd als een opeenvolging van vier periodes: voorbereiding, baan verwerven, eerste werkervaringen en ervaren van succes. Deze vier fasen worden toegelicht, waarbij met name de factoren die een rol zouden kunnen spelen in de verschillende fasen, aan de orde komen. In de laatste paragraaf van dit hoofdstuk worden de onderzoeksvragen beschreven die ten grondslag liggen aan het empirisch onderzoek.

In hoofdstuk 3 wordt de opzet van het onderzoek beschreven. De vier deelonderzoeken staan apart beschreven. In de eerste drie wordt een groep ouderejaars studenten gevolgd tot na hun afstuderen in de eerste baan. De opeenvolgende fasen in het overgangsproces staan in de verschillende studies centraal. Ingegaan wordt op de steekproef, de meetinstrumenten en de procedure. $\checkmark$ anaf hoofdstuk 4 worden de resultaten beschreven.

Hoofdstuk 4 gaat in op de voorbereiding tijdens de opleiding. In deze fase staat sollicitatiegedrag centraal. Dit is de geneigdheid om te solliciteren naar een bepaalde functie. Aangegeven wordt in hoeverre kennis van de arbeidsmarkt, doelgerichtheid, persoonlijkheidskenmerken en de persoonlijke situatie in deze fase van belang zijn.

In hoofdstuk 5 worden de resultaten besproken met betrekking tot de fase van baan verwerven. Gekeken wordt naar de invloed van arbeidsmarktgerichtheid, sollicitatievaardigheden, persoonlijkheidsaspecten en de persoonlijke situatie op het verwerven van een baan.

Hoofdstuk 6 beschrijft de periode van de eerste werkervaringen in de nieuwe functie. Het gaat hierbij om de eerste maanden in de eerste baan na afstuderen. Aangegeven wordt in hoeverre cognities met betrekking tot de ervaringen, omgevingskenmerken, overgangskenmerken en functiekenmerken van belang zijn in deze fase.

In hoofdstuk 7 wordt ingegaan op de fase van het ervaren van succes in de werksituatie. Functiekenmerken, zelfmanagement, loopbaankenmerken en opleidingsaspecten zijn gedefinieerd als belangrijke factoren in deze fase. Beschreven wordt welke rol deze aspecten vervullen in de fase van het ervaren van succes. 
De hoofdstukken 4 tot en met 7 zijn op dezelfde wijze opgebouwd. Allereerst staat in de inleiding kort aangegeven wat onder de fase wordt verstaan, daarna worden de variabelen uit de desbetreffende fase beschreven, in de volgende paragraaf worden de kenmerken van de fase gepresenteerd (de descriptieve data). Ingegaan wordt op mogelijke verschillen tussen mannen en vrouwen die uit de data naar voren komen. Vervolgens wordt ingegaan op de relaties tussen de onafhankelijke en afhankelijke variabelen, tot slot worden resultaten besproken van tests van een causaal model dat aan de data ten grondslag zou kunnen liggen.

Hoofdstuk 8 bevat resultaten van een studie naar de rol van de opleiding in het overgangsproces van de opleiding naar de arbeidsmarkt. In dit hoofdstuk wordt een deelonderzoek gepresenteerd dat gericht is op een vergelijking van de kwaliteiten van studenten die probleemgestuurd onderwijs volgen met studenten die een meer traditioneel opgezet curriculum volgen.

Hoofdstuk 9 vormt het slothoofdstuk waarin een samenvatting wordt gegeven van het onderzoek en waarin de belangrijkste bevindingen met betrekking tot het overgangsproces van opleiding naar arbeidsmarkt worden bediscussieerd. 



\section{Invalshoeken van carrière-studies}

Studies naar carrière-ontwikkeling zijn gebaseerd op heel verschillende uitgangspunten. Dit hangt samen met het feit dat bij carrière-theorieën begrippen worden ontleend aan de psychologie, de sociologie, de economie en aan andere wetenschappen.

Om duidelijk te maken hoe de verschillende concepten zijn gedefiniëerd in deze studie, wordt in dit eerste hoofdstuk aangegeven wat we verstaan onder carrière en carrière-ontwikkeling. Mannen en vrouwen verschillen in de mate waarin zij belang hechten aan een carrière en de mate waarin zij erin slagen een carrière te realiseren. Belangrijke empirische gegevens en opvattingen over de verschillen in de carrière tussen mannen en vrouwen worden eveneens gepresenteerd. De overgang van de ene fase in de carrière naar de volgende vereist bepaalde vaardigheden. Enkele modellen die ingaan op de specifieke vereisten in het overgangsproces komen aan de orde. In de volgende paragraaf wordt ingegaan op succes in de carrière. Welke condities zijn bevorderlijk voor het ervaren van succes? De laatste paragraaf beschrijft de rol van de opleiding in het overgangsproces naar de arbeidsmarkt.

\section{Theoretische achtergrond van het begrip carrière}

Carrière is pas recent object van studie. De basis is gelegd door psychologen en sociologen die zich bezighielden met beroepskeuze. In de zeventiger jaren verschenen boeken van Hall (1976), Schein (1978) en Van Maanen (1977) met de nadruk op carrière-studies. In die tijd verstond men onder carrière een opeenvolging van functies op een steeds hoger niveau in een grote organisatie. Dergelijke carrièrepaden werden van te voren vastgelegd. Door deze drie auteurs werd carrière niet langer beschouwd als een pad dat door het hoger management wordt uitgestippeld, maar als het produkt van een complex onderhandelingsproces tussen individu en organisatie. Een persoon kan zelf vorm geven aan de eigen carrière en hoeft niet uitsluitend een vastgelegd plan te volgen. Een carrière verloopt ook niet alleen verticaal, waarbij sprake is van een steeds hogere functie. Er kunnen ook veranderingen plaatsvinden op hetzelfde functieniveau. Dit wordt ook wel de horizontale carrière genoemd. 
Carrière-studies hebben meestal een interdisciplinair karakter. Het concept carrière behoort niet tot een enkele theorie of discipline. Carrière-studies maken gebruik van inzichten uit de sociologie, psychologie, organisatiekunde, antropologie en economie. Vanuit de sociologische invalshoek is bijvoorbeeld gezocht naar de sociale klasse determinanten van carrière uitkomsten. Psychologische theorieën richten zich bijvoorbeeld op statische dispositionele verschillen en hun implicaties voor de beroepsloopbaan. Vanuit de organisatiepsychologie is belangstelling voor carrièrelijnen in de organisatie en de rol van het management hierbij. Vanuit de antropologie is het inzicht in statusovergangen en de functies van riten ontleend. In de economie wordt carrière beschouwd als afhankelijk van marktmechanismen. De mogelijkheden op de arbeidsmarkt zijn afhankelijk van de economische situatie. Deze veelzijdigheid van perspectieven op carrière is kenmerkend voor carrière-theorieën.

Wat verstaan we eigenlijk onder een carrière? De populaire opvatting van het begrip carrière benadrukt het verwerven van een hoge positie. Carrière wordt vaak gedefinieerd als een opeenvolging van banen die een vooruitgang of verbetering van positie betekent. Door onvrede met deze beperkte betekenis die aan het begrip carrière wordt toegekend, worden vaak alternatieve begrippen gehanteerd, zoals loopbaan (Van de Loo, 1992) of beroepsgeschiedenis. Arthur et al. (1989) geven de voorkeur aan het begrip carrière vanwege de nadruk op de relatie tussen werk en tijd. Een carrière komt tot ontwikkeling in een bepaald tijdsbestek. Ook wij geven de voorkeur aan de term carrière, waarbij we uitgaan van een bredere definitie. Carrière is de volgorde van iemands werkervaringen gedurende een periode. Dit hoeft niet alleen een verbetering van positie in te houden. De betekenis van werk voor de persoon staat centraal in deze definitie. De subjectieve beleving speelt dus een belangrijke rol in tegenstelling tot objectieve criteria. Verder is het begrip tijd belangrijk: de periode waarin een carrière zich ontwikkelt. Ook de voorbereidingsfase maakt hiervan onderdeel uit. In deze zin is de definitie eveneens verbreed vergeleken met de betekenis die Van de Loo bijvoorbeeld geeft aan loopbaanontwikkeling: het verloop van de individuele loopbaan in de tijd, namelijk vanaf het moment van de intrede in het arbeidsproces tot en met de uittrede daaruit. De exacte definitie het begrip carrière is problematisch; datzelfde geldt voor carrière-theorie. Wij kiezen hier de volgende beschrijving: het geheel van generaliseerbare pogingen om carrière-fenomenen te verklaren (Arthur et al., 1989). In carrière-theorie is er een duidelijke link tussen theorie en praktijk. Arthur et al. (1989): our interest is both to learn from and to contribute to practice, so that the multiple individual, institutional and societal parties affected by careers can be better served by the career theory we hold. Verschillende carrière-theorieën hebben een aantal kenmerken gemeenschappolijk. Carrière-theorieën gaan uit van een visie op werksituaties die onderzoek vereist naar zowel individuen als instituties. De definitie van carrière gaat over mensen die werken en over instituties waarin het werk verricht moet worden. Voor het individu kan werk van grote invloed zijn voor de persoonlijke aanpassing en de ontwikkeling in het leven. Carrière-theorie onderscheidt zich van 
theorieen over gedrag in organisaties op het punt van de aandacht voor de persoonlijke verhouding tot de werksituatie. Onderzoek op het gebied van carrière vereist de invalshoek van zowel de persoon als de organisatie waarvoor het werk wordt verricht. Organisatie verwijst naar een sociaal fenomeen waarin een vorm van collectief gedrag relatief vastgesteid en permanent is. Concepten die betrekking hebben op de interactie tussen individu en institutie zijn: identiteit, rol en objectieve en subjectieve visies op de carrière. Belangstelling voor het aspect tijd is expliciet aangegeven in de definitie van carrière, waarbij het immers gaat om de wijze waarop de werkervaringen verlopen gedurende een bepaald tijdsbestek.

Samenvattend: het begrip carrière wordt in dit onderzoek opgevat in de brede betekenis: iedere werkende heeft een carrière. Carrière-theorie omvat een combinatie van de individuele benadering en de institutionele benadering.

\section{De ontwikkelingsbenadering}

De ontwikkelingsbenadering is gebaseerd op de relatie tussen carrière-ontwikkeling en de levensfase van de mens. De ontwikkelingsbenadering van carrières in organisaties is een complex domein. De complexiteit hangt samen met de grote verschillen die er zijn tussen individuen onderling en tussen organisaties. Personen hebben zeer verschillende verwachtingen en vaardigheden en organisaties hebben zeer uiteenlopende behoeften. De verschuiving die momenteel plaatsvindt in deze ontwikkelingsbenadering wordt veroorzaakt door een veranderd opleidingspatroon van werknemers en door veranderingen in de organisatie onder druk van de omgeving. De technologie en de behoeften van organisaties veranderen zo snel dat individuen zich ook voortdurend moeten ontwikkelen en zich moeten aanpassen aan deze veranderende eisen. Dit heeft als consequentie dat niet langer sprake kan zijn van vaste carrièrelijnen. Een bepaald pad kan bijvoorbeeld opgeheven worden en nieuwe paden kunnen ontstaan. Binnen de ontwikkelingsbenadering komt steeds sterker het accent te liggen op de eigen verantwoordelijkheid van mensen invulling te geven aan hun carrière door keuzen te maken, relaties te ontwikkelen en gebruik te maken van kansen die zich voordoen.

Er zijn verschillende typen ontwikkelingsmodellen van carrières: levensloopmodellen, modellen op basis van individuele verschillen en modellen op basis van ontwikkelingsmogelijkheden in organisaties.

\section{levensloop}

Miller en Form (1964) formuleerden als eerste een ontwikkelingsmodel. Zij zagen carrières als een opeenvolgende reeks van sociale aanpassingen in vijf levensperioden:

1. de periode van voorbereiding op werk die gekenmerkt wordt door de socialisatie van een kind thuis en op school op het gebied van werkpatronen en het 
kennismaken met de maatschappelijke normen en waarden ten aanzien van werk.

2. de kennismakingsperiode waarin door middel van vakantiebaantjes en stages eerste werkervaringen worden opgedaan.

3. de fase van uitproberen die start met de eerste baan na de opleiding en die loopt tot aan de eerste vaste werkplek.

4. de stabiele werkperiode omvat de periode van de vaste baan, deze loopt tot

5. de pensionering.

\section{zelf-concept}

Super (1957) heeft ook een levensloopmodel ontwikkeld. Hij stelt bij de carrière-ontwikkeling het zelf-concept centraal. Carrière-ontwikkeling betekent bij hem het implementeren van een zelfconcept en het testen van dit zelfconcept aan de realiteit. Hij onderscheidt vijf fasen die overeenkomst vertonen met de fasen van Miller en Form.

1. Allereerst het groeistadium dat loopt tot veertienjarige leeftijd. In deze periode komt het zelfconcept tot ontwikkeling door middel van identificatie met sleutelfiguren in de familie en op school. Interessen en capaciteiten worden zichtbaar.

2. Hierna volgt het exploratiestadium, van 15 tot 25 jaar. In deze periode komt het zelfconcept verder tot ontwikkeling door het uitproberen van mogelijkheden. Kenmerkend voor dit proces is, volgens Super, het testen van de ideeën over zichzelf aan de realiteit.

3. Het stadium van establishment omvat de periode van 25 tot 45 jaar; een passend werkterrein is gevonden en de persoon probeert hierin een vaste plek te verwerven.

4. Dan volgt het stadium van handhaving van de positie vanaf 45 jaar tot aan de pensionering. In deze periode is sprake van een continuering volgens de bestaande lijnen.

5. Het stadium van afname start op het moment van pensionering en loopt door tot het einde van het leven. In deze periode ligt de nadruk op de rol van de vrije tijdsbesteding voor de zelfverwerkelijking.

\section{psychologische ontwikkeling}

Lievegoed (1991) beschrijft de persoonlijke ontwikkeling in relatie tot de loopbaan. Hierbij maakt hij een onderscheid tussen de biologische en de psychologische ontwikkeling. Wat betreft de biologische ontwikkeling doorloopt iedereen een min of meer vergelijkbare curve. Voor de psychologische ontwikkeling zijn er twee mogelijkheden: de eerste lijn loopt parallel aan de biologische ontwikkeling. Wanneer biologische beperkingen optreden, voelt het individu zich ook psychologisch beperkt om nieuwe zaken aan te pakken. De tweede mogelijkheid is dat het individu op middelbare leeftijd een hoger niveau van creativiteit bereikt. In de verschillende leeftijdsperioden worden verschillende fasen benoemd: de receptieve fase (tot ongeveer 20 jaar), de 
expansiefase, onderverdeeld in de expansieve periode en de organisatie periode (van 20 tot 40 jaar), en de sociale fase waarin men gericht is op de ontwikkeling van anderen in de organisatie (vanaf 40 tot 60-65). Het gaat hierbij om heel globale beschrijvingen.

Lievegoed geeft ook verschillende perspectieven op ontwikkeling. Gekeken kan worden naar de richting van de ontwikkeling; naar het ontwikkelingsproces, naar de ontwikkeling als een situatie en naar de ontwikkeling als een activiteit. Bij de visie op ontwikkeling als een activiteit gaat het om een geplande verandering zoals een organisatie-ont wikkelingsvraagstuk, maar dit kan ook als zelf-management worden gezien op individueel niveau. Essentieel hiervan zijn doelbepaling of het vaststellen van de richting van de ontwikkeling; beleidsbepaling ofwel het vaststellen van de strategie van het ontwikkelingsproces en planning van concrete uitvoerbare stappen. In paragraaf 5 die handelt over succes in de carrière zullen we op deze onderdelen terugkomen.

Opvallend aan deze levensloopmodellen is dat het vrij algemene beschrijvingen van het verloop van carrières zijn. De meeste organisaties bieden individuen de mogelijkheid een identiteit te ontwikkelen als een competent en productief lid. De modellen maken ook duidelijk dat niet iedereen erin slaagt gebruik te maken van deze mogelijkheden van organisaties. Problemen kunnen zich voordoen in het establishmentstadium, wanneer iemand niet in staat is een passend werkplek te vinden en de carrière wordt gekenmerkt door een opeenvolging van onsamenhangende functies. Ook het stadium van handhaving kan stagneren, wanneer individuen er niet in slagen in de organisatie een betekenisvolle positie te behouden.

\section{carrière-ankers}

Een ander type model in deze ontwikkelingsbenadering stelt de individuele verschillen tussen personen centraal. Een voorbeeld hiervan is de indeling van Schein (1978) in carrière-ankers. Scheins model van carrière-ankers is ontstaan uit een longitudinaal onderzoek dat hij heeft verricht onder 44 afgestudeerden van een bepaalde opleiding. Tijdens interviews werd gedetailleerd ingegaan op de werkgeschiedenis en op de redenen die werden gegeven voor bepaalde carrièrekeuzen. Schein vond weinig consistentie in de werkgeschiedenis van mensen maar een hoge mate van consistentie in de redenen die mensen gaven voor de carrièrebeslissingen die ze hadden genomen. Het concept carrière-ankers is ontstaan als een mogelijke verklaring voor het patroon van redenen die de respondenten gaven voor carrièrebeslissingen.

Schein definieert vijf carrière-ankers:

1. technisch-functionele specialisatie,

2. leidinggeven, een algemene managementfunctie verwerven,

3. zekerheid en stabiliteit nastreven,

4. creativiteit, gericht op het ontwikkelen van een produkt of een dienst,

5. autonomie en onafhankelijkheid. 


\section{carrière-ontwikkeling in de organisatie}

Een model van carrière-ontwikkeling op basis van de organisatiestructuur is eveneens ontwikkeld door Schein $(1971,1978)$. Zijn uitgangspunt daarbij is dat de organisatie kan worden beschouwd als een driedimensionele ruimte in de vorm van een kegel. Veranderingen binnen de organisatie bewegen zich langs deze drie dimensies: verticaal, radiaal of aan de omtrek. De verticale beweging geeft de hiërarchische dimensie weer: een stijging of daling in de niveaus van de hiërarchie. Een radiale beweging komt overeen met een toename of afname van de centraliteit van de persoon in de organisatie. Dit geeft de mate aan waarin iemand tot de insiders behoort, tot de vaste kern die over vertrouwelijke informatie beschikt. Beweging rond de omtrek geeft een verandering aan op het functionele vlak, bijvoorbeeld de overgang van een staffunctie naar een managementfunctie.

\section{carrièrefasen en innovaties}

Een ander model van carrière-ontwikkeling in organisaties is ontwikkeld door Dalton en Thompson (1986). Zij onderzochten de carrières van honderden ingenieurs en wetenschappers. Zij kwamen tot de volgende bevindingen. De carrières van professioneel opgeleide werknemers in organisaties verlopen niet langs een rechte weg. Ze verlopen in verschillende, discontinue fasen. Paradoxaal genoeg leiden sommige activiteiten en oriëntaties tot succes in de ene fase, terwijl zij tegelijkertijd de overgang naar de volgende fase belemmeren tenzij ze worden uitgebannen. Twee ideeën staan centraal bij het begrijpen van de carrières van professionals: carrièrefasen en innovaties. Dalton en Thompson onderscheiden vier fasen in carrières, die verschillende activiteiten, vaardigheden en relaties vereisen om succesvol te zijn. Niet alle professionals doorlopen alle vier de fasen. Een meerderheid in het onderzoek kwam niet verder dan de tweede fase. Overgaan van één fase naar de volgende vereist dat men succesvol presteert in de fase die men al heeft bereikt. Het vereist verder dat men vertrouwen wint en ondersteuning krijgt van kern-personen om een begin te maken met het uitvoeren van taken en het opbouwen van relaties die horen bij de volgende fase. Deze processen die horen bij de overgang van de ene fase naar de andere noemen zij innovaties. Het begrip innovaties heeft betrekking op een psychologische verschuiving waardoor een individu zich geleidelijk aan anders opstelt ten opzichte van collega's. Veranderende zelfpercepties en zelfverwachtingen zijn onderdeel van de psychologische verschuiving evenals het duidelijk maken van deze veranderingen aan collega's. Hiermee wordt de relatie met collega's ook anders gedefinieerd. Voor weinig mensen verlopen deze veranderingen geleidelijk en natuurlijk; het merendeel ervaart frustraties in bepaalde fasen van de carrière. Zij zijn degenen die er niet in slagen om innovaties succesvol uit te voeren.

\section{carrièrefasen}

1. Belangrijkste kenmerk van de eerste fase is gesuperviseerd werk. Het werk wordt verricht onder supervisie en leiding van een senior professional in het 
veld. Het werk is nooit helemaal van de medewerker zelf, opdrachten worden gegeven op basis van een groter project. Andere kenmerken zijn: het ontbreken van ervaring en status in de organisatie en het accepteren van supervisie en verwachten van leiding. De taken bestaan voornamelijk uit het uitvoeren van detail- en routine werkzaamheden van een project. Het is van belang om creativiteit en initiatief te laten zien, binnen de gestelde randvoorwaarden. Verder kan men leren te presteren onder druk en een taak uit te voeren in de gegeven tijdsperiode.

2. In de tweede fase is er sprake van verdieping in een probleem of in een technisch gebied; het nemen van verantwoordelijkheid voor een afgebakend deel van een project, waarbij onafhankelijk werken een vereiste is en gestreefd wordt naar het boeken van resultaten.

Het komt nu aan op het opbouwen van geloofwaardigheid en een reputatie in de organisatie. Men steunt minder op de supervisor of mentor en is meer gericht op het ontwikkelen van eigen bronnen om problemen op te lossen. Dit leidt tot een toename in zelfvertrouwen en mogelijkheden.

3. De derde fase wordt gekarakteriseerd door een verbreding van de taken en verantwoordelijkheden. Kenmerk van deze fase is een grote betrokkenheid bij het werk om een aanzienlijke bijdrage te kunnen leveren en tegelijkertijd gaan werken op meerdere terreinen.

Er vindt een verbreding plaats van de technische vaardigheden. Centraal staat stimuleren van anderen door middel van ideeën en informatie. Betrokkenheid bij de ontwikkeling van anderen kan op verschillende wijze vorm krijgen: 1 . als een leider van een kleine groep, 2. als een mentor voor jongere professionals, 3. door de formele positie als supervisor. Contacten onderhouden buiten de organisatie ten behoeve van de organisatie is eveneens kenmerkend voor deze fase.

4. Essentieel voor de vierde fase is het richtinggeven aan de organisatie door het vaststellen van mogelijkheden en belemmeringen. Het gebruiken van formele en informele macht om actie te initiëren en besluiten te beïnvloeden, en om middelen te verkrijgen. In deze fase kan men de organisatie vertegenwoordigen voor individuen en groepen op verschillende niveaus binnen de organisatie, en voor individuen en instituties buiten de organisatie. Men vervult de rol van sponsor voor veelbelovende individuen en bereidt hen voor op kern-rollen in de organisatie.

\section{Vrouwen en carrière}

Vrouwen verschillen van mannen in de ontwikkeling van hun carrière. Tot voor kort werden verschillen tussen mannen en vrouwen op het gebied van de carrière-ontwikkeling niet onderkend. Inmiddels zijn nieuwe modellen ontwikkeld voor de carrière-ontwikkeling van vrouwen en bestaande theorieën uitgebreid om de betekenis van werk voor vrouwen beter te kunnen bevatten. De opvattingen van deskundigen lopen uiteen; sommigen zijn van mening dat 
bestaande theorieën aangepast moeten worden, anderen vinden de verschillen tussen mannen en vrouwen onverenigbaar en pleiten voor aparte modelien voor de carrière-ontwikkeling van vrouwen. De discussie gaat er tegenwoordig dus niet meer over óf mannen en vrouwen verschillen, maar is gericht op het verkrijgen van inzicht in deze verschillen en de implicaties ervan. Erkend wordt dat het mannelijke model van werken en succes een doodlopende weg is; zelfs letterlijk als we kijken naar gezondheidsstatistieken (Bouter \& Van Dongen, 1991). Impliciet in de andere visie van vrouwen op de realiteit is het ter discussie stellen van de gangbare opvattingen over wat essentieel is voor een produktieve en creatieve maatschappij. Deelname aan de arbeidsmarkt wordt daarbij van even groot belang geacht als het uitvoeren van verzorgende taken, zoals het opvoeden van kinderen, de zorg voor ouderen en huishoudelijke werkzaamheden. Deze laatste taken komen nog grotendeels voor rekening van de vrouwen in onze samenleving. Overigens heeft het positieve effecten als mannen meer verantwoordelijkheid nemen voor zorgtaken. Zorgende vaders noemen drie winstpunten: een rechtstreekse (in plaats van 'bemiddelde') relatie met hun kinderen; een completer leven: the best of both worlds; en een betere relatie met de partner (Duindam, 1995). De vraag is van belang hoe men een succesvolle weg kan uitzetten waarbij een evenwicht tussen werk en privé wordt gevonden.

\section{werkmotivatie en werkgedrag}

Astin (1984) geeft een model voor carrière-ontwikkeling dat beroepsmatig gedrag van zowel mannen als vrouwen verklaart. Uitgangspunt hierbij is dat de werkmotivatie voor mannen en vrouwen gelijk is maar dat zij verschillende keuzes maken op grond van vroegere socialisatie-ervaringen en op basis van verschillen in structurele mogelijkheden. Het model definieert peychologische tactoren, namelijk werkmotivatie en verwachtingen en culturele omgevingsfactoren zoals sekse-rol socialisatie en de structuur van mogelijkheden, die in interactie leiden tot bepaalde carrièrekeuzen.

De theorie omvat vier uitgangspunten.

1. Werkgedrag is gemotiveerde activiteit gericht op de bevrediging van drie basisbehoefte: $n$ overleving, plezier beleven en een maatschappelijke bijdrage leveren.

2. Carrièrekeuzen zijn gebaseerd op verwachtingen met betrekking tot de bereikbaarheid van alternatieve vormen van werk en hun mogelijkheid om in de drie basisbehoeften te voorzien.

3. Verwachtingen zijn gedeeltelijk gevormd door vroegere socialisatie in het gezin, in het spel, op school en door eerdere werkervaringen, en gedeeltelijk door de waargenomen structuur van mogelijkheden.

4. Verwachtingen ontwikkeld door socialisatie en perceptie van kansen, kunnen veranderen door veranderingen in de structuur van mogelijkheden; deze verandering in verwachtingen kan weer leiden tot veranderingen in carrièrekeuzen en werkgedrag. 


\section{succesvolle personen}

Larwood en Gattiker (1987) verrichtten onderzoek naar de loopbanen van succesvolle mannen en vrouwen. Zij stellen dat een effectief carrièrestreven van prestatiegerichte personen een lange termijnplanning vereist. Succesvolle personen laten blijken dat zij zich bewust zijn van toekornstige carrièrepaden en hebben inzicht in de instrumentaliteit van bepaalde acties om carrièrevooruitgang te boeken. Er was tevens sprake van stabiliteit in hun prestatiestreven over een bepaalde periode, met andere woorden: zij hielden gedurende een lange periode vast aan een bepaald doel en werkten hier zeer gericht naar toe.

\section{starters}

Uit onderzoek dat door het ROA is verricht, blijkt dat er al bij starters duidelijke sekseverschillen te zien zijn op het gebied van arbeidsmarktparticipatie en het type baan. Mannelijke studenten blijken vaker een full-time baan te hebben kort na afstuderen. Zij hebben vaker een leidinggevende functie en hebben bovendien gemiddeld een hoger inkomen. Deze inkomensverschillen waren zelfs aanwezig na correctie voor leeftijd en vooropleiding. De gevonden verschillen waren significant. Vrouwen bleken vaker een baan te hebben waarvoor een academische opleiding was vereist en werden derhalve minder vaak onderbenut. Vrouwen waren bovendien minder vaak werkloos. Deze verschillen waren echter niet significant (Lodder et al., 1992).

\section{zoekgedrag en toekomstbeeld}

In het onderzoek van Sanders en Van Doorne-Huiskes wordt ingegaan op de verschillende manier van zoeken naar een baan van mannen en vrouwen en de relatie met het toekomstbeeld. Sanders en Van Doorne-Huiskes (1989) beschrijven de job-search-theory van McKenna (1985). Deze theorie gaat uit van de kosten/baten verhouding: het verwerven van arbeidsmarktinformatie brengt kosten met zich mee in de vorm van tijd, geld en alternatieve bestedingsmogelijkheden. Afhankelijk van de waarde die iemand hecht aan het vinden en het hebben van een baan is iemand meer of minder bereid die kosten te maken. Op grond van deze theorie kan het verschil in zoekgedrag van mannen en vrouwen worden verklaard: in het algemeen hechten mannen meer belang aan het hebben en vinden van een baan dan vrouwen en zijn daarom bereid meer kosten te maken bij het zoeken naar een baan. Maar vrouwen verschillen onderling ook sterk. Naarmate vrouwen meer belang hechten aan het vinden van een baan, zullen zij meer geneigd zijn daar (zoek)kosten voor te maken. Sanders en Van Doorne-Huiskes zoeken een verklaring voor verschillen in zoekgedrag in verschillende toekomstverwachtingen. Vrouwen hebben een dubbel en diffuus levensperspectief: zij hebben naast of in plaats van een baan ook nog een perspectief als moeder en/of als echtgenote. Mannen ervaren het perspectief op een baan en op het vaderschap niet als concurrerend. Gevolg is dat vrouwen minder eenduidig op het ene doel van een baan of carrière afkoersen. Dit zal invloed hebben op het arbeidsmarktgedrag en dus ook op het zoekgedrag van vrouwen. 
De begrippen toekomstbeeld en zoekgedrag staan centraal in het onderzoek van Sanders en Van Doorne-Huiskes. Als onderzoeksgroep zijn vrouwen en mannen gekozen die een half jaar na afstuderen werkzaam waren in een fulltime baan. Allen hadden 'mannelijke' hogere beroepsopleidingen gevolgd, namelijk studierichtingen in het Hoger Technisch Onderwijs, het Hoger Economisch en Administratief Onderwijs en de Hogere Landbouwschool. Het toekomstbeeld is vastgesteld door de respondenten te vragen hoe groot zij de kans achten dat ze over 10 jaar nog steeds een full-time baan hebben. Zij onderscheiden zoekgedrag in formele zoekmethoden, zoals het schrijven op een advertentie, en informele zoekmethoden, zoals inschakelen van kennissen of contacten via de stage. Daarnaast keken zij naar de intensiteit van het zoekgedrag: aantal sollicitaties en variatie in methoden van zoeken. $Z i j$ vonden ten aanzien van het toekomstbeeld dat mannen sterker dan vrouwen de verwachting hebben dat zij over 10 jaar full-time werkzaam zijn. Verder constateerden zij dat vrouwen met een partner in mindere mate verwachten over 10 jaar een full-time baan te hebben dan vrouwen zonder partner. Bij mannen doen zich deze verschillen niet voor. Er blijken ook verschillen tussen mannen en vrouwen in de aard van het zoekgedrag. Vrouwen maken vaker dan mannen gebruik van formele zoekmethoden en mannen maken vaker dan vrouwen gebruik van informele zoekmethoden. Naarmate vrouwen meer verwachten in de toekomst een full-time baan te hebben zijn ze meer bereid via informele methoden te zoeken dan vrouwen die minder verwachten in de toekomst een full-time baan te hebben.

\section{Overgangscyclus van Nicholson en West}

In het leven wordt iedereen regelmatig geconfronteerd met grote en kleine veranderingen. In de werksfeer kan men ingrijpende rolveranderingen verwachten. Soms zijn die veranderingen duidelijk en goed gestructureerd, zoals bij werving of pensionering. Maar in andere gevallen komen zij geheel onverwacht of hebben een dramatisch karakter, zoals bij reallocatie en verlies van baan. Dergelijke ervaringen kunnen gezien worden als life-events. Onder lifeevents verstaat men veranderingen in de dagelijkse gang van zaken, die op de een of andere manier van betekenis zijn voor iemands bestaan. Men doelt dan op gebeurtenissen als huwelijk, geboorte en ontslag. Een gebeurtenis is van betekenis als hierdoor schade of verlies voor betrokkene is veroorzaakt, of als belangrijk geachte doelen en plannen bedreigd worden of naderbij komen, of wanneer het zelfbeeld in gunstige of ongunstige zin wordt beïnvloed ( Van de Willige et al., 1985). Zowel negatief als positief geïnterpreteerde gebeurtenissen kunnen van belang zijn. In de vragenlijst voor het meten van life-events is een aparte categorie opgenomen met gebeurtenissen die betrekking hebben op de werksituatie.

Nicholson en West (1988) hebben een model van overgangen ontwikkeld dat diverse veranderingen in de werksfeer kan omvatten. Zij veronderstellen een 
cyclisch model van aanpassing aan overgangen waarin vijf fasen zijn te onderscheiden. De eerste en vijfde fase vallen echter samen. Allereerst is er een periode van anticipatie of voorbereiding waarbij het individu maatregelen neemt of in elk geval zou moeten nemen om zich voor te bereiden op de verandering en de nieuwe taken en verantwoordelijkheden. De tweede fase betreft de eerste ervaringen in de nieuwe baan, ook wel genoemd de periode van de 'reality shock'; deze duurt vanaf de eerste dagen tot enkele weken waarin de persoon ontdekt hoe weinig overeenkomst er is tussen de vorige ervaringen, de verwachtingen en de nieuwe realiteit. De derde fase van de overgangscyclus is aanpassing aan de nieuwe werkomgeving. In het aanpassingsproces zijn twee dimensies te onderscheiden: socialisatie van het individu aan de eisen van de omgeving en het aanpassen of herdefiniëren van de werkomgeving zodat ze beter past bij de individuele behoeften, kwaliteiten en verwachtingen. Succesvolle aanpassing geeft een gevoel van satisfactie en tevredenheid met de baan die kan leiden tot de volgende fase namelijk de stabilisatie. Hierna kan de persoon zich voorbereiden op een volgende verandering en de cyclus start opnieuw. Figuur 1 geeft de overgangscyclus weer.

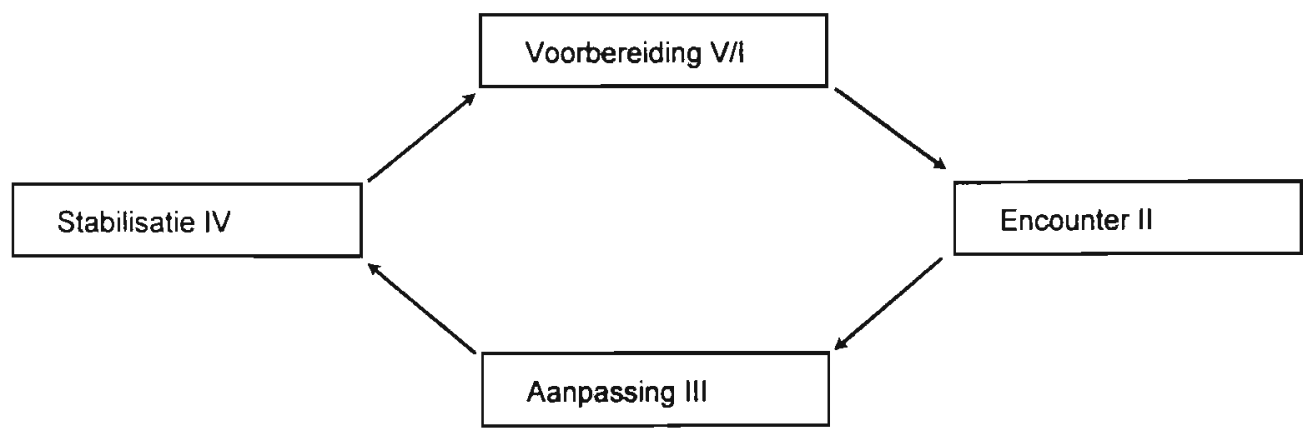

Figuur 1: Overgangscyclus van Nicholson en West (1988)

De overgangscyclus vormt een cirkel waarmee wordt aangegeven dat de eerste fase van een nieuwe cyclus de laatste is van de vorige cyclus. Dit kenmerk van de cyclus geeft een blijvende beweging aan. De ervaring van een overstap maken en een nieuwe stabiele situatie bereiken, is op zich weer een voorbereiding voor de volgende verandering. Een tweede kenmerk van de overgangscyclus is de onderlinge afhankelijkheid van de verschillende fasen. Wat in één fase van de cyclus gebeurt, heeft effect op de volgende fasen. lemand die zich goed voorbereidt op de verandering bijvoorbeeld, is ook goed gewapend tegen confrontaties in de fase van de eerste ervaringen. Het derde kenmerk van de cyclus heeft betrekking op discontinuitteit. De cyclus heeft discontinue fasen, met elk kwalitatief verschillende taken, ervaringen, problemen en oplossingen. De opeenvolgende fasen van de overgangscyclus worden hieronder uitgebreid beschreven. 
In de voorbereidende fase maakt het individu zich gereed om de overgang te maken. De persoon vraagt zich af wat de nieuwe taken en verantwoordelijkheden zullen zijn en of hij of zij in staat zal zijn om er op een succesvolle manier mee om te gaan. We mogen ook verwachten dat er een bepaalde mate van angst en onzekerheid aanwezig is over de indruk die men zal maken op de nieuwe leidinggevende en collega's. Onzekerheid over de eigen prestaties is sterk afhankelijk van het zelfvertrouwen dat iemand heeft, hetgeen samenhangt met de eerdere ervaringen die iemand heeft opgedaan. Verder zijn concrete voorbereidingen essentieel. In welke mate heeft men informatie verzameld voorafgaand aan de overgang? Hoe duidelijk of gedetailleerd zijn iemands verwachtingen? Met welke gevoelens en motieven anticipeert men de verandering? Hoe goed voelt men zich toegerust wat betreft kennis en vaardigheden met het vooruitzicht op de toekomstige verandering?

De voorbereidingsfase van de overgangscyclus is vooral belangrijk vanwege het effekt op volgende fases. Als men bijvoorbeeld overdreven hoge verwachtingen heeft in de voorbereidende fase dan zal dit leiden tot een reeks teleurstellingen in de fase van de eerste ervaringen. Dit kan zelfs nog doorspelen in de aanpassingsfase of in de stabilisatiefase. In een onderzoek vroegen Nicholson en West aan managers welke aspecten van de nieuwe baan zij als het meest bedreigend zagen voorafgaand aan de verandering. In het algemeen bleek dat het anticiperen op een verandering van baan niet bijzonder stressvol werd ervaren. Hierbij moet wel worden opgemerkt dat de voorbereidingsfase op restrospectieve wijze onderzocht werd bij managers die al in de organisatie een bepaalde functie hadden en waar ze een nieuwe functie kregen. Uit het onderzoek bleek dat de managers zich vooral zorgen maakten over hun toekomstige prestaties en of hun bijdragen gewaardeerd zouden worden door invloedrijke personen op het werk. De minste zorgen maakte men zich over de aansluiting van de nieuwe baan op de privésituatie en over de toekomstige relaties met de chef en collega's. Nicholson en West interpreteren dit als een indicatie dat managers vinden dat ze voldoende capaciteiten en vaardigheden hebben om relaties te hanteren, maar dat ze onzeker zijn over de criteria waarmee taakgerichte vaardigheden en persoonlijke kwaliteiten beoordeeld worden. De angst was sterker bij degenen die een baan kregen bij een andere werkgever dan voor de managers die intern een andere functie kregen. $\mathrm{Er}$ bleken ook duidelijke sekseverschillen in de mate van angst en onzekerheid in de voorbereidingsfase. In alle leeftijdsgroepen ervoeren vrouwen een hogere mate van angst dan mannen. De onderzoekers schrijven dit verschil toe aan de dubbele uitdaging voor vrouwen: aanpassen aan verandering en geaccepteerd zien te worden in een door mannen gedomineerde omgeving.

\section{de eerste ervaringen}

Tot voor kort werd er weinig aandacht besteed aan de allereerste periode in de nieuwe baan. De mate waarin de harde realiteit van het werkend bestaan wordt ervaren in de periode van de eerste ervaringen in de nieuwe baan, ook 
wel genoemd de 'reality shock', is een gevolg van de psychologische voorbereiding van de nieuwkomer. Louis $(1980)$ heeft een gedetailleerde beschrijving gegeven van de cognitieve processen in deze fase, waarin betekenis moet worden toegekend aan de nieuwe omgeving.

In haar beschrijving van de ervaringen van nieuwkomers maakt zij een onderscheid tussen veranderingen, contrasten en verrassingen. Verandering heeft betrekking op de objectieve verschillen tussen de nieuwe en de vorige rolvereisten, status en werkomgeving. Het begrip contrast slaat op de persoonspecifieke ervaringen die iemand meeneemt van de vorige ervaringen naar cle nieuwe werksetting. Bijvoorbeeld de ervaring van een goede informele sfeer tussen collega's onderling zal sterk contrasteren met meer formele contacten tussen collega's op de nieuwe werkplek. Verrassingen hebben betrekking op positieve en negatieve aspecten. Een implicatie van de opvattingen van Louis is dat er altijd verrassingen zullen zijn voor degene die van baan verandert, ondanks alle goede voorbereidingen. Uit het onderzoek van Nicholson en West blijkt dit inderdaad het geval te zijn. Zij vroegen hun proefpersonen aan te geven welke verrassingen zij hadden ervaren in hun nieuwe baan en om deze verrassingen te beoordelen als positief, negatief of neutraal. Hierbij werden acht bronnen van verrassingen onderscheiden die gegroepeerd werden in drie algemene gebieden: werk context, baan context en zichzelf. $25 \%$ van de steekproef beschreef verrassingen in elk gebied; $73 \%$ gaf aan dat er sprake was van verrassingen op minstens één van deze terreinen. Verrassingen ervaren is dus een tamelijk universele korte-termijn reactie op verandering van baan, zelfs als de verandering binnen een bekende organisatie plaatsvindt; hoewel verrassingen meer uitgesproken zijn bij verandering naar een nieuwe organisatie. Dit type verandering vereist dus een grotere aanpassing dan verandering binnen de organisatie.

Wat vond men zoal verrassend aan de werkcontext, de baancontext en aan zichzelf? Wat betreft de werkomgeving werd de algemene werksfeer heel wisselend beoordeeld, variërend van gespannen en formeel tot een gemakkelijke en vriendelijke sfeer. De opleidingsmogelijkheden veroorzaakten met name negatieve verrassingen. De meeste verrassingen en voornamelijk negatief werden veroorzaakt door de kwaliteit van de communicatie en besluitvorming op de nieuwe werkplek. De baaninhoud was eveneens een grote bron van verrassingen, maar over het algemeen meer positief dan de werkomgeving. Positief commentaar kwam op de mate van verantwoordelijkheid en onafhankelijkheid in de nieuwe baan. Negatieve verrassingen hadden vooral betrekking op de supervisie die men onvoldoende vond. De verrassingen die de eigen reacties op de overgangssituatie opriepen waren zowel positief als negatief. Negatieve verrassingen werden veroorzaakt door de moeizame integratie in de nieuwe baan, positieve reacties kwamen doordat men nieuwe kwaliteiten en mogelijkheden bij zichzelf ontdekte.

Een conclusie is dan ook dat zelfs bij een interne verandering in een organisatie verrassingen een normale reactie zijn. Dat de verrassingen toch voorname 
lijk negatief getint zijn, zou te wijten kunnen zijn aan onjuiste verwachtingen als gevolg van een onvoldoende voorbereiding op de verandering.

\section{aanpassing}

Verandering van werkrol vereist dat men zich aanpast aan de nieuwe rol en aan de bijbehorende sociale relaties. Deze aanpassing kan twee contrasterende processen inhouden. In de eerste plaats is er de reactieve verandering in het individu, variërend van kleine veranderingen in de dagelijkse routine en gewoonten, tot grotere veranderingen in relaties en zelfbeeld. Aanpassing kan ook inhouden dat de nieuwe rol wordt veranderd, zodat hij beter past bij de persoon. Dit kan variëren van kleine initiatieven zoals het veranderen van werktijden en roosters tot meer ingrijpende rolinnovaties zoals veranderingen in de hoofddoelen van de organisatie. Vaak vereisen rolveranderingen ook aanpassing in de privésfeer, dit speelt vooral een rol bij verhuizing voor een nieuwe baan.

Uitkomsten van verandering in de werkrol kunnen voorspeld worden vanuit drie sets van factoren: 1 . de nieuwe rolvereisten, 2 . persoonlijke disposities, zoals vroegere beroepsocialisatie en motivationele oriëntatie, 3 . socialisatieprocessen in de organisatie. De twee vocrnaamste uitkomsten zijn persoonlijke verandering waarbij het individu zich aanpast aan de organisatie en rolinnovatie, waarbij de baan zodanig wordt veranderd dat hij beter past bij de persoon. De baan wordt als het ware naar de eigen hand gezet.

Aanpassing geschiedt op vier verschillende wijzen.

1. replicatie: hierbij is er sprake van weinig aanpassing van het individu en weinig naar de hand zetten van de rol. Een voorbeeld van dit type verandering is de cassière bij $V \& D$, die van de sokkenafdeling naar de onderbroeken verhuist.

2. Bij absorptie vindt weinig verandering plaats van de nieuwe rol, maar wel een grote individuele aanpassing. Een voorbeeld is de pasafgestudeerde die in een bedrijf komt te werken zonder eerdere werkervaring. Alle aandacht zal gericht zijn op aanpassing aan de nieuwe omgeving waardoor ontwikkeling van de eigen identiteit plaatsvindt, en er zal daarentegen weinig aandacht zijn voor het invoeren van innovaties.

3. Bepaling is het tegenovergestelde van absorptie. De verandering eist weinig persoonlijke aanpassing, maar leidt tot ingrijpende rolinnovatie; bijvoorbeeld een technisch specialist die grote veranderingen doorvoert op de nieuwe werkplek, zonder dat dit erg van invloed is op zijn of haar professionele identiteit.

4. Exploratie slaat op de situatie waarbij zowel de persoon als de rol veranderen door het aanpassingsproces.

Twee dimensies van rolvereisten beïnvloeden sterk de bepaling van deze uitkomsten. De eerste is de nieuwigheid van de baan, de tweede is de speelruimte. Het tweede type voorspellers van het aanpassingsproces heeft betrekking op persoonlijke aanleg, namelijk behoefte aan controle en behoefte aan feedback. Behoefte aan controle is de persoonlijke tegenhanger van baan- 
speelruimte. Hoge niveaus van beide worden geassocieerd met rolinnovaties als een aanpassingstrategie. Mensen met een sterke behoefte aan feedback zullen gevoelig zijn voor invloed, communicatie en wensen van anderen. In deze zin is behoefte aan feedback de persoonlijke tegenhanger van nieuwigheid van de baan. Beide leiden vooral tot persoonlijke verandering als aanpassingsvorm.

\section{stabilisatie}

De stabilisatiefase is een periode van consolidatie; een bepaald evenwicht is bereikt en er zullen geen grote veranderingen plaatsvinden. Meestal duurt deze fase niet lang. Voor veel mensen is de stabilisatiefase van de overgangscyclus het beginpunt van een nieuwe cyclus. Vaak volgen veranderingen in het werk elkaar zo snel op dat het proces van aanpassing nauwelijks achter de rug is of er volgt alweer een nieuwe cyclus van verandering. De stabilisatiefase gaat dan over in een nieuwe voorbereidingsfase.

\section{Succes in de carrière}

Het psychologisch succesmodel (Hall, 1976) beschrijft hoe personen zelfwaardering en competentie ontwikkelen in hun carrière. Als mensen doelen bereiken die centraal staan in het zelfconcept dat ze voor zichzelf hebben gemaakt, waar ze onafhankelijk naartoe hebben gewerkt en die een uitdagend maar bereikbaar niveau van aspiratie representeren, dan ervaren ze psychologisch succes en verhoogde zelfwaardering. Deze verhoogde zelfwaardering ontstaat vermoedelijk omdat dit succes een nieuw gebied of niveau van bekwaamheid onthult. Dus de persoon heeft een nieuw aspect van zijn of haar identiteit ontdekt. In overeenstemming met Hall kan dit proces worden uitgebreid naar de carrière subidentiteit. Als een bepaald doel leidt naar een nieuw niveau van bekwaamheid en naar een verhoogde zelfwaardering en zelfvertrouwen, dan geldt dit eveneens voor de perceptie van de subidentiteit op dat gebied. Succes zal dus tot een groei van de subidentiteit leiden. Dit zal een verhoogde satisfactie met de taken en verhoogde betrokkenheid bij het werk tot gevolg hebben. De persoon zal meer dan tevoren geneigd zijn nieuwe doelen te stellen. Deze cyclus van gebeurtenissen kan zelfversterkend en continu zijn.

Het stellen van de juiste doelen is essentieel in dit succesmodel. De volgende criteria zijn van toepassing:

1. het doel is gesteld door de persoon;

2. de weg naar het doel is vastgesteld door de persoon;

3. het doel wordt als uitdagend of moeilijk gezien maar ook als bereikbaar;

4. het doel is in overeenstemming met de zelfidentiteit;

5. het doel wordt als relevant voor de carrièrerol beschouwd.

Karakteristieken die leiden naar psychologisch succes zijn de mate van uitdaging in het werk en de mate van autonomie. Hall is van mening dat het 
psychologisch succesmodel van carrièregroei zowel de eerste keuzen omvat als ook de latere carrière-ontwikkeling beschrijft. Als een student in de jaren voorafgaand aan het werk bij taken die hij in relatie ziet met een bepaald beroep, succes ondervindt, dan zal de resulterende voldoening zijn interesse vergroten in een carrière op dat gebied. Deze ervaring zal het begin van bewustwording van een potentiële subidentiteit representeren.

Volgens Hall zijn de eerste jaren kritiek voor de verdere ontwikkeling van de carrière. Wanneer een persoon voor het eerst een organisatie binnenkomt, begint hij met bepaalde vaak onrealistische verwachtingen. De carrièresubidentiteit groeit erg snel tijdens dit eerste werkjaar. Het proces van psychologisch succes omvat leren, het ontwikkelen van vertrouwen in de omgeving, het verwachten of anticiperen op succes na het stellen van doelen, inspanning en uitvoering afhankelijk van de mogelijkheden van de omgeving. Het voorkomen van deze aspecten heeft waarschijnlijk een continue invloed op de carrière in de volgende jaren. Hall stelt dat de mate waarin iemands eerste werkervaringen condities verschaffen voor psychologisch succes (uitdaging en autonomie) een essentiële rol speelt in zijn carrière-ontwikkeling in de volgende jaren. In de volgende figuur is het psychologisch succesmodel weergegeven.

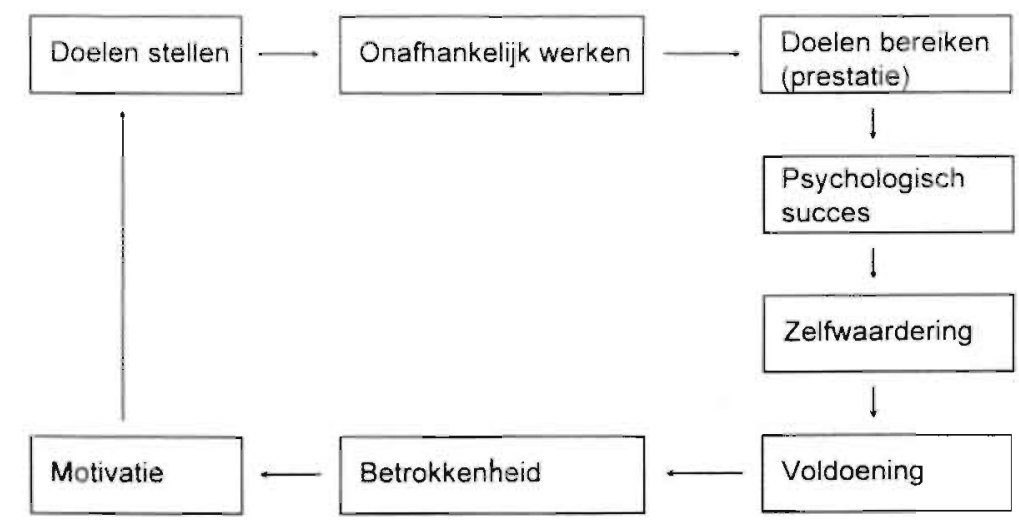

Figuur 2: De succescyclus

Psychologisch falen in de carrière is niet simpelweg het tegengestelde van het psychologisch succesmodel. Het hangt af van de hoeveelheid zelfwaardering van de persoon of falen leidt tot zoekgedrag of dat het aspiratieniveau en de betrokkenheid wordt verlaagd. Wanneer de persoon eerder ondersteuning en probleemoplossende hulp ontvangt dan straf voor falen, dan is hij meer geneigd zijn volgende doelen te bereiken.

Spangenberg en Nijhuis (1990) hebben een studie uitgevoerd naar de attributie van succes en falen door wetenschappers. De attributietheorie gaat ervan 
uit dat percepties van prestaties in het verleden en hun determinanten relevant zijn voor de huidige prestaties. Individuen hebben uiteenlopende succeservaringen die van invloed zijn op hun huidige prestaties. Spangenberg en Nijhuis hebben medewerkers van een wetenschappelijke afdeling geklassificeerd als hoog of laag presteerders op basis van hun wetenschappeliike produktie over enkele jaren, en de personen gevraagd naar causale attributies voor succes en falen. Het blijkt dat laag presteerders zowel succes als falen toeschrijven aan externe oorzaken. Hoog presteerders schrijven succes toe aan interne oorzaken en falen aan externe oorzaken.

\section{De rol van de opleiding}

Hall (1976) spreekt over de dichotomie tussen de opleiding en de arbeidsmarkt. In de hierboven beschreven modellen wordt de overgang van de opleiding naar de arbeidsmarkt dan ook steeds besproken los van de gevolgde opleiding. De vraag is echter of dit een juist uitgangspunt is. Het is algemeen bekend dat studenten uit bepaalde studierichtingen moeilijk een baan kunnen vinden, bijvoorbeeld studenten uit de kunstrichtingen; andere studierichtingen liggen in een bepaalde periode wel goed in de markt, bijvoorbeeld technische opleidingen. Het ROA onderzoekt de aansluiting van verschillende studierichtingen op de arbeidsmarkt met behulp van de arbeidsmarktscanner. Het ROA makt prognoses voor baanopeningen en voor de instroom van schoolverlaters. Onder baanopeningen verstaat men de totale vraag naar nieuwkomers in een beroepsklasse. Op basis van deze prognoses worden uitspraken gedaan over de arbeidsmarktperspectieven van verschillende opleidingstypen. Het gaat hierbij om de interpretatie van een kwantitatieve weergave van de arbeidsmarktpositie van studierichtingen (Ramaekers \& Heijke, 1991).

Naast de arbeidsmarktpositie van de studie kunnen de inhoud van de studie en de wijze waarop het onderwijs wordt aangeboden, relevant zijn voor het overgangsproces van de opleiding naar de arbeidsmarkt. Miller en Form (1964) noemden de opleiding al een belangrijke bron om te leren wat het betekent om te werken. Zij doelden hiermee op het regelmatig werken en plannen van werkzaamheden dat tijdens de studie is vereist. Ook Lievegoed (1991) benadrukt het belang van goed onderwijs als een basis voor het functioneren in de werksituatie. Onderwijs dat gericht is op reproductie van kennis, leert de student slechts te vertrouwen op zijn geheugen en daarvan vooral gebruik te maken. Onderwijs dat gericht is op het oplossen van problemen en het beantwoorden van vraagstukken geeft studenten vertrouwen in de eigen mogelijkheden om oplossingen te vinden en om met plezier nieuwe problemen aan te pakken. Dit is een pleidooi voor een probleemgestuurde aanpak van onderwijs, waarin probleemoplossen centraal staat.

Bepaalde studieactiviteiten kunnen specifiek bijdragen aan de voorbereiding op de arbeidsmarkt. We kunnen hierbij denken aan stage-ervaringen en bedrijfsbezoeken maar ook aan het gebruik van cases uit de beroepspraktijk 
in de opleiding of het oefenen van simulaties uit de praktijk. Elementen uit de studie zijn daarom van belang voor de overgang naar de arbeidsmarkt.

Wanneer we een analyse maken van advertenties voor hoger opgeleiden, zien we dat naast de vereiste kennis voor een bepaald inhoudelijk vakgebied een aantal vaardigheden en persoonlijkheidskenmerken worden gevraagd. Kennis en inzicht zijn tegenwoordig onvoldoende voor het krijgen van een baan. De kandidaat moet ook in staat zijn om te communiceren, te presenteren, zowel mondeling als schriftelijk (een vlotte pen), samen te werken met collega's, te onderhandelen met opdrachtgevers. Verder moet zij of hij beschikken over een analytisch denkvermogen, doorzettings-en incasseringsvermogen, een flexibele instelling, een initiatiefrijke instelling en humor. Toch worden de meeste van deze vaardigheden en persoonlijke kwaliteiten niet genoemd in de eindtermen van opleidingen; met andere woorden in de meeste academische opleidingen komen bovengenoemde vaardigheden en kwaliteiten niet expliciet aan de orde. Hoe moeten studenten zich deze vaardigheden dan eigen maken en hoe kan men weten of men hierover beschikt?

Swieringa en Wierdsma (1990) zijn van mening dat in opleidingen te weinig aandacht wordt besteed aan het verwerven van vaardigheden. De nadruk ligt eenzijdig op het verwerven van kennis en inzicht. Maar kennis is pas bruikbaar bij de toepassing ervan op problemen uit de praktijksituatie en hiervoor zijn bepaalde vaardigheden noodzakelijk. Een organisatie die opgewassen is tegen de snelle ontwikkelingen in de maatschappij, bestaat uit personen die meegaan in die ontwikkelingen en nieuwe informatie kunnen leren. Het vermogen om te leren en in ontwikkeling te blijven is belangrijker dan de feitelijke kennis die iemand heeft. Volgens hen is deze houding essentieel.

Deze visie op leren is ook te vinden in de uitgangspunten van probleemgestuurd leren. Met probleemgestuurd onderwijs wordt beoogd om een continu en zelfgestuurd leerproces te realiseren bij de studenten.

Het probleemgestuurd onderwijs (PGO) heeft een aantal kenmerken waardoor bepaalde vaardigheden of kwaliteiten worden bevorderd die mogelijk van invloed zijn op het functioneren in de werksituatie. Een van de kenmerken van PGO is dat de casuistiek in de opleiding ontleend is aan de beroepspraktijk en een multidisciplinaire benadering vereist. De problemen die een student tijdens de opleiding krijgt voorgelegd komen overeen met de vraagstukken die in de praktijksituatie van belang zijn. Studenten leren vanaf het begin van de opleiding te werken volgens een systematische methode van probleemoplossen, waarbij zelf richting geven aan het leerproces en zelfwerkzaamheid belangrijke aspecten zijn. Door het samenwerken in kleine groepen leert men groepsprocessen hanteren en leidinggeven aan een groep. We zouden kunnen veronderstellen dat deze kenmerken van PGO bevorderlijk zijn voor de aansluiting op de arbeidsmarkt. Dit zou betekcnen dat afgestudeerden ervaren dat het gevolgde PGO-onderwijs hen handvatten heeft gegeven om de problemen in de beginsituatie in hun eerste baan te hanteren. 


\section{2}

\section{Carrière-ontwikkeling van studenten}

In het vorige hoofdstuk zijn verschillende perspectieven op carrière-onderzoek besproken. Hierbij werd aangegeven op welke wijze deze perspectieven een rol spelen in deze studie. In dit hoofdstuk gaan we dieper in op de specifieke fase in de carrière-ontwikkeling van studenten, die onderwerp is van dit onderzoek, namelijk de periode van de overgang van de opleiding naar de arbeidsmarkt. Zoals aangegeven in verschillende modellen van carrière-ontwikkeling (Super, 1957; Miller \& Form, 1964; Schein, 1978; Lievegoed, 1991) vindt de voorbereiding op de carrière voornamelijk plaats tijdens de opleiding. De wijze waarop men zich tijdens de opleiding voorbereidt, zal van invloed zijn op het verdere verloop van de loopbaan. Een goede voorbereiding kan bijdragen tot een succesvolle overstap naar de arbeidsmarkt en een slechte voorbereiding zal leiden tot een moeizame overgang naar de beroepspraktijk. Maar wat bepaalt nu een goede of een slechte voorbereiding? Waaraan kunnen we die herkennen? In de literatuur komen enkele aspecten naar voren, maar die zijn niet erg uitgewerkt. Een voorbeeld is 'weten wat het betekent om te werken' (Porter et al., 1975); uiteraard is dat een moeilijk te meten concept.

Om te komen tot een model voor de overgangsfase van de opleiding naar de arbeidsmarkt maken we gebruik van de overgangscyclus van Nicholson en West (1988). Zij beschrijven een veranderingsproces in verschillende stappen die logisch op elkaar volgen. Tegelijkertijd zijn de verschillende fasen in de cyclus discontinu, dat wil zeggen, binnen die fasen zijn verschillende taken, ervaringen, problemen en oplossingen te onderscheiden. Zij onderscheiden de fasen:

1. voorbereiding, gericht op anticipatie op de verandering;

2. encounter, waarbij de allereerste ervaringen in de nieuwe baan worden bedoeld;

3. aanpassing aan de nieuwe situatie door middel van socialisatie van het individu of door het herdefiniëren van de werkomgeving; en

4. de stabilisatie-fase waarin een evenwicht is gevonden in de veranderde situatie en eventueel een nieuwe verandering in gang kan worden gezet.

In het overgangsproces van de opleiding naar de arbeidsmarkt gaan wij hier eveneens uit van vier fasen met vergelijkbare taken en kenmerken. Daarbij is echter gekozen voor een meer specifieke benaming van de verschillende fasen en een groter accent op de voorbereiding. De voorbereidingsfase van 
Nicholson en West is opgesplitst in een algemene voorbereidingsfase en een fase van baanverwerven. De tweede en derde fase van Nicholson en West zijn samengevoegd. We komen dan tot de volgende indeling:

1. De voorbereidingsfase, waarin activiteiten worden ontplooid als voorbereiding op de arbeidsmarkt.

2. De fase van het verwerven van een baan, waarin de feitelijke overgang naar de arbeidsmarkt wordt gemaakt.

3. De fase van de eerste werkervaringen waarbij de confrontatie met de werksituatie ertoe dwingt om aanpassingen te maken.

4. De fase van het ervaren van succes die vergelijkbaar is met de stabilisatiefase. Hierbij is de aanpassing aan de werksituatie succesvol verlopen.

De eerste twee en de laatste twee fasen lopen geleidelijk in elkaar over. De eerste twee fasen vallen grotendeels in de periode dat men nog studeert. Tijdens de laatste twee fasen is de stap naar de arbeidsmarkt gemaakt. Tussen de tweede en derde fase is dan ook een duidelijke scheiding aan te geven, namelijk het moment dat men een baan heeft verworven en start in de eerste baan. Dit vormt het uitgangspunt voor de uitgevoerde studie; zie figuur 3.

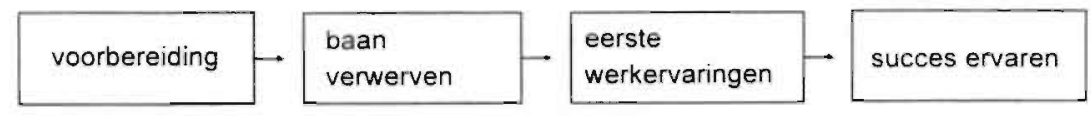

Figuur 3: Overgangsproces van opleiding naar arbeidsmarkt

Hierna volgt een bespreking van de verschillende onderdelen. Hoe worden de periodes gedefinieerd? Wat zijn specifieke kenmerken van de verschillende fasen. Welke variabelen zijn relevant bij het onderzoeken van dit overgangsproces?

\section{Voorbereiding}

Tijdens de opleiding wordt door de student gestart met de voorbereiding op de arbeidsmarkt. Dit zal meestal in de eindperiode van de opleiding gebeuren. In deze periode worden activiteiten ontplooid gericht op oriëntatie op de arbeidsmarkt en solliciteren. Er is uiteraard geen duidelijk tijdstip aan te geven waarop de voorbereidingsfase aanvangt. Sommige studenten beginnen eerder met solliciteren dan anderen. Vaak wordt solliciteren zelfs uitgesteld tot na het afstuderen. Welke taken, ervaringen, problemen en oplossingen spelen in deze fase een rol? De belangrijkste taak is het ontplooien van sollicitatiegedrag in de brede zin van het woord. Hieronder verstaan we niet uitsluitend het gericht solliciteren naar een baan maar ook activiteiten op het gebied van arbeidsmarktoriëntatie. In tabel 2.1 zijn de concepten aangegeven die in de voorbereidende fase mogelijk van belang zijn. 
Tabel 2.1: Factoren en hun indicatoren die in de voorbereidingsfase van invloed zouden kunnen zijn op sollicitatiegedrag

$\begin{array}{ll}\text { Kennis van de arbeidsmarkt } & \text { - werkervaring } \\ & \text { - stage-ervaringen } \\ \text { Doelgerichtheid } & \text { - planmatig gedrag } \\ & \text { - concrete plannen } \\ \text { Persoonlijkheidskenmerken } & \text { - self-efficacy } \\ & \text { - prestatiegerichtheid } \\ & \text { - leeftijd } \\ \text { Persoonlijke situatie } & \text { - studiejaar } \\ & \text { geslacht }\end{array}$

\section{kennis van de arbeidsmarkt}

In de voorbereidingsfase zijn kennis van de arbeidsmarkt en inzicht verwerven in de eigen positie daarop essentieel. Vaak wordt tijdens de opleiding gestart met solliciteren in oriënterende zin. Welke functies zijn er zoal? Welke functies zijn geschikt voor een starter op de arbeidsmarkt met de opleiding die ik heb gevolgd? Hiervoor worden de kranten en vakbladen uitgeplozen. Het verwerven van algemene beroepsinformatie wordt door verschillende onderzoekers genoemd als een belangrijk onderdeel van de voorbereidende fase (Crites, 1976; Hall, 1976; Schreurs \& Van de Pol, 1985). Algemene beroepsinformatie heeft betrekking op kennis van en inzicht in beroepen, functies en organisaties. Niet alleen de feitelijke kennis is van belang maar ook inzicht in de betekenis van verschillende functies in organisaties, de bijbehorende taken en bevoegdheden. Verondersteld mag worden dat degenen die werkervaring hebben opgedaan voorafgaand aan hun studie of tijdens hun studie beschikken over meer algemene beroepsinformatie. Deze kennis zou van invloed kunnen zijn op het sollicitatiegedrag. Van Nieuwenhuysen en Wielers (1990) noemen het verrichten van werk en bestuursactiviteiten tijdens de studie als kwaliteitskenmerken van de afgestudeerden die de arbeidsmarktpositie verbeteren. Ook de stage zal mogelijk een belangrijke bron zijn voor het verwerven van algemene beroepsinformatie. In de stage leert men wat het betekent om te werken in een organisatie en men verwerft inzicht in het functioneren ervan. Wanneer de stage-ervaringen positief zijn, kan dit beschouwd worden als een succes-ervaring die stimulerend is voor het verkrijgen van toekomstig succes (Hall, 1976). We verwachten dan ook dat goede stage-ervaringen zullen bijdragen aan de voorbereiding op de arbeidsmarkt.

Eerdere werkervaring en het belang van de stage in het kader van de voorbereiding op de arbeidsmarkt zijn als onafhankelijke variabelen in de voorbereidingsfase betrokken. 


\section{doelgerichtheid}

Verder is het van belang om een goed inzicht te hebben in de eigen interesses en mogelijkheden. Ook dit wordt algemeen erkend als een essentieel onderdeel van een goede voorbereiding (Schreurs \& Hommes, 1992; Stoner \& Freeman, 1993). Pas wanneer duidelijk is waar de belangstelling naar uit gaat, zal men in staat zijn om doelen te stellen. Daarna kan men plannen maken om de gestelde doelen te realiseren. Doelgerichtheid, dat wil zeggen: in staat zijn om doelen te formuleren en deze op een planmatige wijze benaderen, is dan ook een belangrijke vaardigheid in de voorbereiding op de arbeidsmarkt. In de succescyclus van Hall (1976) neemt doelgerichtheid een belangrijke plaats in. Bowditch en Buono (1990) beschrijven de 'goal-setting'-theorie als een van de benaderingen van motivationeel gedrag in organisaties. De basispremisse van deze theorie is dat de bewuste doelen van een persoon de belangrijkste determinanten zijn van taakgerelateerde motivatie, aangezien de doelen richting geven aan denken en handelen. Uit onderzoek blijkt dat specifieke doelen tot hogere inspanningen leiden dan algemene doelstellingen. We veronderstellen dat degenen die in hoge mate doelgericht en planmatig zijn ingesteld, gerichter activiteiten ondernemen om de gewenste baan te bereiken. We gaan ervan uit dat planmatig handelen samenhangt met sollicitatiegedrag.

Verder kunnen we verwachten dat de concrete plannen die men heeft voor de periode na het afstuderen van invloed zijn op de intensiteit van solliciteren. De plannen die men heeft, kunnen variëren van het werken in een betaalde baan, een andere studie gaan volgen, een tijd op reis gaan tot geen plannen hebben. Wanneer men wil gaan werken in een betaalde baan zal men intensiever solliciteren dan wanneer men geen duidelijk idee heeft over de toekomst. Planmatig gedrag en plannen na afstuderen zijn twee variabelen uit de voorbereidingsfase.

\section{persoonlijkheidskenmerken}

Persoonlijkheidskenmerken zullen ook van invloed zijn op de wijze van voorbereiding op de arbeidsmarkt. Met name kan daarbij gedacht worden aan selfefficacy en prestatiegerichtheid.

Het beeld dat men heeft voor de eigen toekomst zou een rol kunnen spelen in de effectiviteit van de huidige gedragingen. Het blijkt dat degenen die verwachten een taak tot een goed einde te brengen, vaker in staat zijn daadwerkelijk te bereiken wat hun voor ogen stond. Dit fenomeen wordt self-efficacy genoemd. Self-efficacy kan gezien worden als vertrouwen in de eigen capaciteiten om met bepaalde levensstressoren om te gaan (Schwarzer, 1992). Selfefficacy kan de motivatie verhogen. Mensen met een hoog niveau van selfefficacy kiezen uitdagende taken; zij stellen zichzelf hogere doelen en zijn vasthoudend in het nastreven ervan. Bij tegenslagen zijn zij in staat om snel te herstellen. In onderzoek wordt self-efficacy in verband gebracht met prestaties, afwezigheid van emotionele stoornissen, mentale en fysieke gezondheid en carrièrekeuzes. We mogen dan ook verwachten dat degenen die ervan uitgaan de gewenste baan te krijgen, meer activiteiten ondernemen om dit te 
realiseren. Zij anticiperen als het ware op succes. Als indicatie van selfefficacy is aan studenten gevraagd of zij verwachten dat ze de gewenste functie daadwerkelijk krijgen.

We veronderstellen dat prestatiegerichtheid van belang zal zijn in de voorbereidingsfase. De behoefte om goed te presteren in allerlei situaties zal ertoe leiden dat de persoon het verwerven van een baan ook als een te leveren prestatie zal zien. lemand met een hoge prestatiegerichtheid zal dan ook sterk gemotiveerd zijn om te solliciteren tegen de tijd dat het afstuderen nadert. We verwachten dat een hoge prestatiemotivatie zal samenhangen met een actieve houding bij het solliciteren. Prestatiegerichtheid is als onafhankelijke variabele meegenomen in het onderzoek.

Probleemoplossend vermogen wordt ook beschouwd als een belangrijk aspect in de voorbereidingsfase. In de voorbereidingsfase zal men voor bepaalde problemen komen te staan die men moet zien op te lossen. Het zou dan ook kunnen zijn dat degene met een groot probleemoplossend vermogen, vroeger begint met solliciteren.

\section{persoonlijke situatie}

De persoonlijke situatie kan ook van invloed zijn op de wijze van voorbereiding. Enkele achtergrondvariabelen zijn in dit verband geformuleerd, te weten leeftijd, studiejaren en geslacht. De leeftijd kan een rol spelen. Een jonge student zal misschien minder haast hebben om te beginnen met solliciteren dan een oudere student of iemand die al een eerdere opleiding heeft gevolgd. Leeftijd is een van de achtergrondvariabelen in het onderzoek.

We mogen veronderstellen dat het studiejaar ook van invloed zal zijn op het sollicitatiegedrag. Vijfde en zesdejaars zullen waarschijnlijk meer sollicitatieactiviteiten ontplooien dan vierdejaars studenten. Voor hen is de druk om af te studeren waarschijnlijk groter en de overstap naar de arbeidsmarkt komt dichterbij. In het onderzoek kijken we naar de invloed van het studiejaar van de student.

Er zijn aanwijzingen dat mannen en vrouwen anders zich voorbereiden op de arbeidsmarkt. Broekmate en Schreurs (1994) hebben een onderzoek verricht naar effecten van de trainingen solliciteren en loopbaanontwikkeling. Hieruit bleek dat vrouwelijke studenten in verhouding vaker deelnamen aan de training solliciteren dan mannelijke studenten. Verder bleek dat mannen er minder tegen op zagen om te solliciteren dan vrouwen, na afloop van de training. Mannen bleken een sollicitatiegesprek ook minder moeilijk te vinden dan hun vrouwelijke medestudenten. De kwaliteit van de sollicitatiegesprekken werd beoordeeld door gastdocenten. Uit deze beoordelingen bleek dat vrouwelijke sollicitanten enkele vragen beter beantwoordden dan hun mannelijke collega's. Namelijk de vraag naar de motivatie voor de functie en naar hun kwaliteiten op het gebied van schrijfvaardigheden. Deze verschillen zouden kunnen wijzen op een meer intensieve voorbereiding door vrouwen. 
Uit een onderzoek van Stuurman (1993) onder mannelijke en vrouwelijke alumni van de Katholieke Universiteit Brabant, blijkt dat vrouwen zich uitge breider oriënteren op de arbeidsmarkt dan mannen.

Sanders (1991) vond echter weinig verschillen in zoekgedrag van mannen en vrouwen. Mannen ontvangen alleen vaker dan vrouwen informatie uit hun ' $\mathrm{gift}^{\prime}$-netwerk. Hieronder worden familie, kennissen en vrienden verstaan die beroepsinformatie als een 'gift' aanbieden.

\section{Verwerven van een baan}

De voorbereidende fase loopt geleidelijk over in de periode waarin gericht gezocht wordt naar een betaalde functie. Dit gebeurt veelal als het afstuderen in zicht is of wanneer men daadwerkelijk de studie heeft beëindigd. Wat zijn de belangrijkste taken, ervaringen, problemen en oplossingen in deze fase? De hoofdtaak of het doel van deze fase is het verkrijgen van een betaalde baan. De start in een betaalde functie is het criterium voor het succesvol doorlopen van deze fase. Welke factoren spelen mogelijk een rol in de fase van baan verwerven? In tabel 2.2 worden de relevante concepten uit de fase van baan verwerven in schema gebracht.

Tabel 2.2: Factoren en hun indicatoren die in de fase van baanverwerven mogelijk van invloed zouden kunnen zijn op het al dan niet hebben van een baan

$\begin{array}{ll}\text { Arbeidsmarktgerichtheid } & \text { - studiekeuze } \\ & \text { omvang dienstverband } \\ & \text { - gerichtheid op hogere functie } \\ \text { - gerichtheid op ontplooing } & \text { - sociale vaardigheden } \\ \text { - leidinggeven } & \text { - zelfwardering } \\ \text { Persoonlijkheidsaspecten } & \text { self-efficacy } \\ \text { Persoonlijke situatie } & \text { - geslacht }\end{array}$

\section{arbeidsmarktgerichtheid}

Allereerst is het van belang dat men een duidelijk beeld heeft van de gewenste functie én tevens kan inschatten of het functieniveau passend is. Sommige studenten studeren meer arbeidsmarktgericht dan anderen. Reeds bij de studiekeuze blijkt dit. Wanneer iemand vanuit arbeidsmarktperspectief heeft gekozen voor de studie, verwachten we dat de persoon een gerichtere aan- 
dacht heeft voor de arbeidsmarkt en zijn positie daarin. Als gevolg daarvan verwachten we een hogere mate van succes in het verwerven van een baan. Van Nieuwenhuysen en Wielers (1990) vonden in hun studie dat de keuze voor een studierichting of afstudeerrichting met een betere arbeidsmarktpositie de individuele kansen op de arbeidsmarkt doen toenemen. Zij concluderen dat een sterke oriëntatie op de arbeidsmarkt zich na het afstuderen loont.

Ook de voorkeur voor de omvang van het dienstverband zal van invloed zijn op het vinden van een baan. Het zal relatief gemakkelijker zijn om een fulltime baan te vinden dan een parttime functie. Verder zouden we kunnen verwachten dat iemand die pas is afgestudeerd en een volledig dienstverband ambieert, sterker gemotiveerd is om een baan te vinden. De gewenste omvang van het dienstverband is dan ook een van de onafhankelijke variabelen die in het onderzoek meegenomen zal moeten worden.

De motieven die men nastreeft in een loopbaan zijn mogelijk ook van invloed op het realiseren van een baan. Dit komt tot uiting in het begrip loopbaananker (Schein, 1978). Een loopbaananker is het geheel van gepercipieerde talenten en vaardigheden, motieven en behoeften, attitudes en waarden, die een persoon in zichzelf erkent. Het is een relatief constant element en is daardoor van grote invloed op de professionele ontwikkeling van de persoon. Derr (1986) heeft loopbaanankers beschreven als persoonsoriëntaties: een oriëntatie op vrijheid, oriëntatie op uitdaging en ontplooiing, oriëntatie op zekerheid, gerichtheid op het bereiken van een hogere functie en gerichtheid op evenwicht. Bij sommige loopbaanankers lijkt het verwerven van een baan belangrijker dan bij andere. Naarmate iemand sterker gericht is op het verwerven van een hogere functie, mogen we verwachten dat het krijgen van een baan erg belangrijk is voor die persoon en dat er dus ook meer moeite wordt gedaan om een baan te krijgen. We verwachten dat gerichtheid op een hogere functie van invloed zal zijn op het verwerven van een baan. Hetzelfde geldt voor de motieven gericht op uitdaging en ontplooiing. Wanneer dit motief in sterke mate een rol speelt, zal actiever gezocht worden naar een baan en eerder een baan worden verkregen dan in het geval zelfontplooiing een geringe rol speelt. Gerichtheid op een hogere functie en gerichtheid op ontplooiing zijn mogelijk van invloed en zullen daarom meegenomen moeten worden als onafhankelijke variabelen in de fase van baan verwerven.

\section{sollicitatievaardigheden}

Naast het uitzoeken van een passende vacature is de eigen presentatie in de brief en in het sollicitatiegesprek belangrijk. Wanneer we kijken naar de literatuur over selectiemiddelen (Vander Meeren, 1993) ofwel predictoren in het selectieproces dan blijkt dat communicatieve vaardigheden essentieel zijn. Het selectie-interview wordt het meest toegepast. Er zijn allerlei varianten mogelijk: een tandem-, panel-, of serie-interview, waarbij steeds goede communicatievaardigheden van pas komen. Bij persoonlijkheidsvragenlijsten worden sociale vaardigheden gemeten. In een assessment center wordt vaak een groepsdiscussie gehouden, waarbij met name gelet wordt op communicatieve 
en managementvaardigheden. We denken hierbij aan het overtuigen van anderen en het sturen en richting geven aan een aanvaardbare oplossing voor de groep. Sociale vaardigheden en leidinggevende kwaliteiten zijn onafhankelijke variabelen in de fase van baan verwerven.

\section{persoonlijkheid}

Persoonlijkheidsaspecten worden vrijwel altijd in het selectieproces betrokken, naast vakinhoudelijke kennis en vaardigheden. Swieringa en Wierdsma (1990) geven aan dat in sommige grotere bedrijven met name wordt gekeken naar de persoonlijkheid. Vakinhoudelijke kennis wordt in interne opleidingen verzorgd. Van Vianen (1987) stelt dat in de eindfase van de selectieprocedure vaak de persoonlijkheid van de kandidaat doorslaggevend is.

Zelfwaardering wordt in diverse onderzoeken genoemd als een relevant concept. lemand met een hoge zelfwaardering zal zich beter presenteren in de sollicitatieprocedure dan iemand met een lagere zelfwaardering. Een hoge zelfwaardering zal samenhangen met het vertrouwen om een bepaalde baan goed aan te kunnen. Dit geeft een bepaalde uitstraling waardoor anderen de capaciteiten van de persoon hoger zullen waarderen en deze persoon eerder zullen aannemen voor een functie dan een sollicitant die minder zelfvertrouwen uitstraalt. Verder zal men bij een hoge mate van zelfwaardering meer vasthoudend zijn om een complexe taak goed te volbrengen dan bij een lagere zelfwaardering ook al ervaart men onzekerheid en tegenslag. lemand met een hoge zelfwaardering zal zich niet meteen laten ontmoedigen door een afwijzing bij een sollicitatie.

We verwachten dat self-efficacy eveneens een rol zal spelen. Wanneer men de inschatting maakt om datgene te bereiken wat men wil, lijkt de kans groter om dat ook daadwerkelijk te realiseren. Uit een onderzoek van Van Vianen en Keizer (1992) blijkt self-efficacy van belang bij de doorstroming van vrouwen naar leidinggevende functies. Een lage self-efficacy leidt tot vermijding van de taak. Een hoge self-efficacy zal leiden tot een grotere betrokkenheid bij de taak en vergroot de kans dat de taak succesvol wordt uitgevoerd. Dit speelt blijkbaar een rol bij de doorstroming in de organisatie. We mogen aannemen dat dit eveneens van belang is bij de entree in de organisatie.

\section{persoonlijke situatie}

Aspecten van de persoonlijke situatie spelen ook een rol in het verwerven van een baan. Gekeken wordt naar de invloed van ges/acht op het verwerven van een baan. We zouden mogen verwachten dat leeftijd geen rol meer speelt wanneer de keuze eenmaal is gemaakt om gericht te solliciteren naar een baan. lemand komt al dan niet in aanmerking voor een functie op basis van ervaringen en kwaliteiten. 


\section{Eerste werkervaringen}

Nadat men begonnen is in een eerste baan start een nieuwe fase. De periode van het verwerven van een baan heeft men succesvol afgerond. Met veel verwachtingen begint men op de nieuwe werkplek, maar tegelijkertijd is men ook erg onzeker. De start in de eerste baan kan beschouwd worden als een 'life event'; een van de meest belangrijke gebeurtenissen in een bepaalde levensperiode. Zowel positieve als negatieve kanten van de gebeurtenis kunnen van belang zijn bij een life-event (Van de Willege et al., 1985). Latack (1989) beschrijft gebeurtenissen en processen in de carrière, zoals veranderingen van baan, ontslag of reorganisatie, met behulp van stressmodellen. De stress die met de situatie gepaard gaat, heeft positieve en negatieve aspecten. Positief zijn de mogelijke kansen en uitdagingen, negatief is de onzekerheid die de situatie met zich meebrengt.

Wat zijn de belangrijkste taken, ervaringen, problemen en oplossingen in deze fase? De activiteiten in deze fase zijn erop gericht om te wennen aan de werksituatie en zichzelf te handhaven. Een indicatie van het gewend zijn aan de werkomgeving en zich hierin te kunnen handhaven is de positieve waardering voor de werksituatie.

In tabel 2.3 worden de concepten uit de fase van de eerste werkervaringen in schema gezet.

Tabel 2.3: Factoren en hun indicatoren die in de fase van de eerste werkervaringen van invloed zouden kunnen zijn op de waardering van de werksituatie

$\begin{array}{ll}\text { Cognities } & \text { - coping gedrag } \\ & \text { - negatieve ervaringen } \\ & \text { - verrassingen } \\ \text { Omgevingskenmerken } & \text { - sociale steun } \\ & \text { - feedback } \\ \text { Overgangskenmerken } & \text { - rolverandering } \\ \text { Functiekenmerken } & \text { - uitdaging } \\ & \text { - functievoorkeur }\end{array}$

\section{cognities}

In de eerste plaats speelt de perceptie van onzekerheid in de situatie een belangrijke rol. In het stressmodel wordt hierbij gerefereerd aan het belang van cognities. In de eerste periode tijdens een nieuwe baan zullen veel situaties 
onverwachte elementen bevatten. Vrijwel alle ervaringen zijn nieuw, of binnen een nieuwe context. Deze nieuwe gebeurtenissen kunnen positief en negatief worden ervaren. Aan afgestudeerden wordt gevraagd naar de aard van hun positieve en negatieve ervaringen tijdens de eerste periode in de nieuwe functie. Verder wordt gevraagd naar de manier waarop men hiermee is omgegaan, het zogenaamde coping gedrag. Coping strategieën kunnen gericht zijn op de situatie (rechtstreekse actie), op de cognities (cognitieve herwaardering) of op de stressreacties (symptoombestrijding) (Latack, 1989). In het begin is het van belang dat men moeilijke situaties op het werk leert hanteren.

Verder wordt een nieuwkomer geconfronteerd met 'verrassingen' (Louis, 1980). Verrassingen zijn situaties of gebeurtenissen die niet overeenkomen met de verwachtingen die men ervan had. Een discrepantie tussen verwachting en realiteit kan betrekking hebben op de organisatie, het werk of op het eigen functioneren. In het laatste geval kunnen verrassingen leiden tot een verandering in het zelfbeeld. Verrassingen vereisen eveneens adequaat coping gedrag. In dit kader wordt vaak gesproken over de 'reality shock'. Nieuwkomers hebben van te voren onrealistische verwachtingen over hun nieuwe baan. In de praktijk valt het dan tegen, waardoor enkelen vroegtijdig de organisatie verlaten (Cummings \& Huse, 1989).

\section{kenmerken van de omgeving}

Aangezien de periode van de eerste werkervaringen beschouwd wordt als een stressvolle situatie kan sociale steun van de omgeving belangrijk zijn. Ondersteuning kan worden geboden door de leidinggevende, collega's en door personen uit de privésfeer. Bij werkstress lijkt vooral de sociale steun van de chef en collega's van belang. Janssen (1992) beschrijft vier verschillende uitwerkingen van het begrip sociale steun: de mate van sociale integratie, de ervaren kwaliteit van de relaties, perceptie van hulpbereidheid en hulpgevend gedrag. De vraag naar ondersteuning tijdens de eerste werkervaringen heeft vooral betrekking op de perceptie van hulpbereidheid en hulpgevend gedrag. Een goede introduktie op de werkplek zal ook ondersteuning en houvast bieden in de beginsituatie. Kluytmans (1993) schrijft dat de introduktie alle activiteiten omvat die door een organisatie worden ondernomen om de wederzijdse aanpassing tussen individu en organisatie te bevorderen. Het gaat niet alleen om informatieverschaffing aan nieuwkomers maar ook om werkinstructies, interne opleidingen en trainee-activiteiten. De inwerkperiode wordt heel verschillend ingevuld in organisaties. De mogelijkheden variëren van het ontbreken van een inwerkperiode: de nieuwkomer wordt vanaf het eerste moment in het diepe gegooid; tot een uitgebreide inwerkperiode waarbij men gedurende het eerste jaar nauwelijks verantwoordelijkheden krijgt en alle gelegenheid krijgt om te observeren hoe er wordt gewerkt. Een goede introduktie in de baan zal positief bijdragen aan het aanpassingsproces in de organisatie.

Verder is feedback op het functioneren belangrijk. In het begin is onduidelijk aan welke standaard de taken moeten voldoen. Door feedback van anderen 
ontstaat hierover duidelijkheid. In de meeste gevallen zal de leidinggevende feedback geven op de werkzaamheden van de nieuwkomer. De kwaliteit en bruikbaarheid van de feedback is hierbij van belang. Cummings en Huse (1989) noemen feedback in een adem met coaching. Feedback op de prestaties geeft duidelijkheid over het functioneren, tegelijkertijd is van belang om begeleiding te bieden om de prestaties te kunnen verbeteren en de gestelde doelen te bereiken.

\section{overgangskenmerken}

In de periode van de eerste werkervaringen zal men een andere rol moeten innemen. Men heeft niet langer de rol van student met bijbehorende taken en gedragingen, maar men moet de rol van een werknemer aannemen met alle bijpassende taken en verantwoordelijkheden. Deze rolverandering verloopt niet voor iedereen gemakkelijk, maar wordt soms als zeer abrupt ervaren.

Het is erg belangrijk voor het functioneren in de baan om de eerste tijd goed door te komen. De periode werkzaam in de functie hangt samen met de mate waarin men gewend is in de organisatie en de functie waardeert. In de beginperiode is de onzekerheid groot en kan de nieuwe werksituatie stress oproepen (Latack, 1989). Wanneer men goed kan omgaan met deze situatie raakt men gewend aan de organisatie en zal de stress afnemen. In het begin speelt ook het effect van de sollicitatieperiode. Men heeft positieve verwachtingen van de nieuwe functie en heeft ervaringen in het werk die tegenstrijdig zijn aan dit beeld. Na enige tijd is men beter in staat de balans op te maken van de positieve en negatieve kanten van de nieuwe baan. De periode waarin men werkzaam is in de functie, is een van de afhankelijke variabele in deze fase.

\section{functiekenmerken}

Niet alleen omgevingsfactoren zijn van belang voor de waardering van de baan, kenmerken van de functie zullen eveneens een rol spelen. De mate van uitdaging in de eerste baan blijkt sterk van invloed te zijn op de prestaties en het ervaren van succes in de baan na enkele jaren (Porter et al., 1975; Cummings \& Huse, 1989). De verklaring die hiervoor wordt gegeven is dat personen die in het begin uitdagende taken krijgen, een hoge werkstandaard internaliseren en positieve attitudes ten aanzien van werk ontwikkelen. Uitdagende taken bieden verder de mogelijkheid om de eigen kennis, vaardigheden en competentie te ontwikkelen. Dit zal eveneens een rol spelen voor de toekomstige prestaties.

Verder speelt een rol in hoeverre men de functievoorkeur heeft kunnen realiseren. Voor afstuderen had men een bepaald idee van de gewenste functie. Het gaat hierbij waarschijnlijk niet uitsluitend om de persoonlijke voorkeur maar ook om een idee over een passende baan. Met welk werkveld heeft men de meeste affiniteit en in welke organisatie verwacht men het best te kunnen functioneren. Wanneer deze voorkeur is gerealiseerd zal men meer tevreden zijn dan wanneer men is uitgeweken naar een andere baan. In het laatste geval zal de nieuwkomer meer aanpassingen moeten maken. 


\section{Succes ervaren}

De eerste tijd in de organisatie vindt een aanpassingsproces plaats, dat van tijd tot tijd moeizaam zal verlopen. Wanneer men in staat is om de stress in de eerste werkperiode goed te hanteren, dan is aan de eerste voorwaarde voldaan voor het ervaren van succes. Een indicatie hiervan is de opvatting succesvol te zijn in het werk. Men heeft het gevoel op de goede plek te zitten en is tevreden over de eigen bijdrage aan de organisatie, met andere woorden men vindt zichzelf succesvol bijdragen aan de organisatie. Succesvol zijn vormt de afhankelijke variabele in deze fase.

Welke factoren dragen ertoe bij dat succes wordt ervaren in de werksituatie? In tabel 2.4 worden relevante factoren en hun indicatoren beschreven.

Tabel 2.4: Factoren en hun indicatoren die van invloed zouden kunnen zijn op het ervaren van succes

$\begin{array}{ll}\text { Functiekenmerken } & \text { - specialisatie } \\ \text { Zelfmanagement } & \text { autonomie } \\ & \text { - planning } \\ \text { Loopbaankenmerken } & \text { - belang loopbaan } \\ & \text { - periode werkzaam } \\ \text { Opleidingsaspecten } & \text { - kennis } \\ & \text { - vaardigheden }\end{array}$

\section{functivikemerken}

Bij sommige functies is duidelijk omschreven wat van de medewerker wordt verwacht. Bepaalde specialistische kennis is vereist om de taken uit te voeren. Bil nieuwkomers op de arbeidsmarkt gaat het vaak om kennis waarin men zich heeft verdiept tijdens de stage. Van Nieuwenhuysen en Wielers (1990) geven aan dat een stageplaats soms resulteert in een baan. In dit geval kan men de geleerde kenis an vaardigheden meteen toepassen in de werksituatie Dit geeft houvast. Het zal dan ook gemakkelijker zijn om een evenwicht te vinden in het werk, dan wanneer brede en algemene kennis en vaardigheden zijn vereist. Bij een functie die meer generalistische kennis vraagt, zal het moeilijker zijn greep te krijgen op de werkzaamheden. Kluytmans (1993) geeft aan dat zowel tijdens de selectie als bij de introduktie veel aandacht wordt besteed aan technische, instrumentele vaardigheden. Dit zijn vaardigheden die vaak via formele opleidingen worden verworven. Normen over de arbeidsrol 
en de organisatiecultuur leert men meestal op informele wijze, in de omgang met collega's. Deze aspecten zijn belangrijker bij een generalistische functie. De mate van autonomie in de werkzaamheden is in dit verband ook relevant. Volgens Hall (1976) is een zekere autonomie in de functie-uitoefening noodzakelijk voor het ervaren van succes. Wanneer bepaalde taken onder strakke supervisie van een chef goed zijn uitgevoerd zal dit minder effect hebben op de zelfwaardering dan wanneer deze taken zelfstandig zijn uitgevoerd. Huse en Cummings (1989) beschrijven het model voor het categoriseren van baankenmerken (van Hackman en Oldman). Autonomie is hierbij één van de vijf kerndimensies, naast variatie in vaardigheden, taak identiteit, belang van de taak en feedback van het werk. Autonomie wordt gezien als de mate waarin de werknemer onafhankelijk is in zijn werk en de vrijheid heeft in het plannen en uitvoeren van het werk. Een grote mate van autonomie geeft een groot gevoel van persoonlijke verantwoordelijkheid voor de resultaten. De mate van autonomie in het werk is een van de onafhankelijke variabelen in deze fase.

\section{zelfmanagement}

Zelfmanagement is erop gericht persoonlijke waarden te realiseren. Mensink (1994) geeft een onderscheid in vijf stappen van zelfmanagement: bepalen van waarden, zelfonderzoek, stellen van doelen, verbeteren van prestaties en zelfevaluatie. Het concretiseren van doelen en het maken van een planning om deze doelen te realiseren en daardoor de prestaties te verbeteren zijn essentieel. We mogen dan ook verwachten dat de mate waarin iemand in staat is om een goede planning te maken zal bijdragen aan de succeservaringen in het werk.

Het verkrijgen van goede en bruikbare feedback zal nodig zijn voor het ervaren van succes. Feedback vormt een belangrijk hulpmiddel bij zelfevaluatie. Op basis van feedback kunnen de prestaties worden geëvalueerd en nieuwe doelen worden gesteld. Planning en feedback vormen onafhankelijke variabelen in de fase van succeservaren.

\section{loopbaankenmerken}

We veronderstellen dat het belang dat men hecht aan een beroepsloopbaan samenhangt met het ervaren van succes. Wanneer men een loopbaan erg belangrijk vindt, zal men in sterke mate betrokken zijn bij het werk en zich inspannen om succesvol te zijn in het werk. De periode waarin men werkt in de baan speelt hierbij een rol. In de beginperiode in een nieuwe organisatie is alle energie nodig om het aanpassingsproces goed door te komen. Na enige tijd wordt voor de nieuwkomer duidelijk wat precies wordt verwacht en kunnen de prestaties hierop worden afgestemd. Men moet de beginperiode gepasseerd hebben om succes te kunnen ervaren. De periode waarin men werkzaam is in de functie vormt een onafhankelijke variabele in deze fase. 


\section{opleidingsaspecten}

De aansluiting van de opleiding op de functie speelt een rol in deze fase. In hoeverre kunnen verworven kennis en vaardigheden worden gebruikt in de baan? Vooral in de eerste jaren na afstuderen zal de beschikbare kennis en vaardigheden houvast geven. Na de beginperiode zal men meer gebruik maken van nieuwe kennis en vaardigheden die men zich eigen heeft maakt in de werksituatie (Swieringa \& Wierdsma, 1990).

\section{Onderzoeksvragen}

In de vorige paragrafen staat per fase een tabel beschreven met de relevante variabelen. In opeenvolgende meetmomenten werden de verschillende fasen van het overgangsproces onderzocht. De kernvariabelen zijn sollicitatiegedrag in de voorbereidingsfase, het hebben van een baan als onderdeel van de fase van baanverwerven, waardering voor de functie en het ervaren van succes in de werksituatie. Dit zijn de afhankelijke variabelen die in de opeenvolgende fases zijn gedefinieerd.

Sollicitatiegedrag stond centraal in de eerste meting. Hierbij werd een loopbaanenquête afgenomen onder ouderejaars studenten. Het verwerven van een baan werd een jaar later gemeten met behulp van een vragenlijst bij dezelfde groep respondenten. De derde meting vond weer een jaar later plaats en bestond uit een gestructureerd interview met een steekproef uit de respondenten van de eerdere metingen. Hierbij werden de waardering van de werksituatie en het ervaren van succes gemeten.

De resultaten van het onderzoek bestaan uit een descriptief gedeelte en een analytisch gedeelte. In de rapportage zullen allereerst de kenmerken van de verschillende fasen worden gepresenteerd. Relevante verschillen tussen mannen en vrouwen worden besproken. Veronderstelde relaties tussen variabelen worden getoetst. Gepoogd wordt om de variabelen die behoren tot een bepaalde fase, onder te brengen in een causaal model. De hoofdstukken vier tot en met acht bestaan dan ook uit een descriptief en een analytisch gedeelte.

\section{voorbereiding}

In de voorbereidende fase werd met name gekeken naar het sollicitatiegedrag van studenten. Onderzocht werd welke variabelen hierop van invloed zijn. Verondersteld werd dat kennis van de arbeidsmarkt, doelgerichtheid, persoonlijkheid en de persoonlijke situatie een rol zullen spelen bij het sollicitatiegedrag. De variabelen zijn ondergebracht in deze categorieën. De volgende onderzoeksvragen over de voorbereidende fase zullen worden beantwoord: 1. Wat zijn de kenmerken van de voorbereidingsfase? Zijn er verschillen tussen mannen en vrouwen in de voorbereiding?

2. In hoeverre zijn kennis van de arbeidsmarkt, doelgerichtheid, persoonlijkheid en persoonlijke situatie van invloed op sollicitatiegedrag?

3. Hoe verhouden de variabelen uit de voorbereidingsfase zich onderling? 


\section{verwerven van een baan}

De fase van baan verwerven heeft als afhankelijke variabele het hebben van een baan. Verondersteld werd dat arbeidsmarktgerichtheid, sollicitatievaardigheden, persoonlijkheidskenmerken en de persoonlijke situatie hierop van invloed zijn. De onderzochte variabelen vallen onder deze categorieën.

De volgende onderzoeksvragen hebben betrekking op de fase van baan verwerven:

4. Wat zijn de kenmerken van de fase van baan verwerven? Zijn er verschillen tussen mannen en vrouwen in deze fase?

5. In hoeverre zijn arbeidsmarktgerichtheid, sollicitatievaardigheden, persoonlijkheid en persoonlijke situatie van invloed op het vinden van een baan?

6. Hoe verhouden de variabelen uit de fase van baan verwerven zich onderling?

Deze vragen worden in hoofdstuk vijf beantwoord.

\section{eerste werkervaringen}

In de fase van de eerste werkervaringen werd de waardering van de werksituatie gedefinieerd als de afhankelijke variabele. De waardering van de werksituatie zal afhangen van cognities, omgevingskenmerken, overgangskenmerken en functiekenmerken. De onderzochte variabelen hebben betrekking op deze categorieën.

De volgende onderzoeksvragen zullen worden beantwoord met betrekking tot de fase van de eerste werkervaringen:

7. Wat zijn de kenmerken van de fase van de eerste werkervaringen? Zijn er verschillen tussen mannen en vrouwen in deze fase?

8. In hoeverre zijn cognities, omgevingskenmerken, overgangskenmerken en functiekenmerken van invloed op de waardering van de werksituatie?

9. Hoe verhouden de variabelen uit de fase van de eerste werkervaringen zich onderling?

In hoofdstuk zes wordt ingegaan op deze vragen.

\section{succes ervaren}

In de fase van succes ervaren werd ervaren van succes tevens als afhankelijke variabele gedefinieerd. Zoals eerder in dit hoofdstuk beschreven, veronderstellen we dat kenmerken van de functie, zelfmanagement, loopbaankenmerken, en opleidingsaspecten hierop van invloed zijn. De onderzochte variabelen zijn hiervan afgeleid.

De volgende onderzoeksvragen hebben betrekking op de fase van het ervaren van succes:

10. Wat zijn de kenmerken van de fase van ervaren van succes? Zijn er verschillen tussen mannen en vrouwen in deze fase?

11. In hoeverre zijn functiekenmerken, zelfmanagement, loopbaankenmerken en opleidingsaspecten van invloed op het ervaren van succes? 
12. Hoe verhouden de variabelen uit de fase van het ervaren van succes zich onderling?

In hoofdstuk zeven komen deze vragen aan bod.

\section{causale modellering}

Tenslotte is een poging gedaan om voor elke fase een causaal model te formuleren en te testen. Gegeven de staat waarin de theorievorming van dit domein zich bevindt, kan dit niet anders dan exploratief zijn. De verklaringsmodellen worden gepresenteerd in de hoofdstukken van de desbetreffende fases.

\section{rol van de opleiding}

Daarnaast zijn enkele onderzoeksvragen geformuleerd over de rol van de opleiding in het overgangsproces van de opleiding naar de arbeidsmarkt. Een aparte vraagstelling heeft betrekking op de vergelijking tussen studenten die probleemgestuurd onderwijs en studenten die traditioneel onderwijs hebben gevolgd. De onderzoeksvragen luiden als volgt:

13. In hoeverre is de opleiding bruikbaar in de werksituatie?

14. Zijn er verschillen in perceptie van de opleiding tussen studenten die PGO volgen en studenten in traditioneel onderwijs.

15. Beoordelen mannen en vrouwen de opleiding verschillend?

Deze vragen worden besproken in hoofdstuk acht.

In het negende hoofdstuk worden de resultaten van het onderzoek geïntegreerd. Kernelementen in de carrière-ontwikkeling van studenten in het overgangsproces van opleiding naar arbeidsmarkt worden bediscussieerd. 


\section{Opzet van het onderzoek}

In dit hoofdstuk wordt de opzet van het onderzoek gepresenteerd. Het onderzoek is gericht op het overgangsproces van de opleiding naar de arbeidsmarkt voor studenten. Om recht te doen aan het procesmatige karakter van deze periode werd gekozen voor een longitudinale opzet van het onderzoek. Een groep studenten werd gevolgd tijdens dit overgangsproces en op drie momenten benaderd. Deze vormden de eerste drie deelonderzoeken van deze studie. Het eerste deelonderzoek, de loopbaanenquête, betrof een schriftelijke enquête onder ouderejaars studenten over hun toekomstige loopbaan. Het tweede deelonderzoek bestond uit een aantal vragenlijsten en psychologische tests die zijn afgenomen rond de periode van afstuderen. Hiermee werd onder andere gepeild of de afgestudeerden al een baan hebben. Het derde deelonderzoek betrof het carrière-interview dat is afgenomen bij afgestudeerden die werkzaam zijn in hun eerste baan. Ervaringen in de werksituatie kwamen hierbij aan bod. Daarnaast werd een onderzoek opgezet waarin de kwaliteiten van studenten die probleemgestuurd onderwijs hebben gevolgd, werden vergeleken met studenten die een meer traditionele opleiding volgen. Dit vormde het vierde deelonderzoek van deze studie.

Deze vier deelonderzoeken zullen achtereenvolgens worden besproken en gerelateerd aan de onderzoeksvragen die in het vorige hoofdstuk zijn geformuleerd. Hierbij wordt ingegaan op de steekproef, de onderzoeksinstrumenten en de procedure. Een omschrijving van de gekozen variabelen en een presentatie van de statistische kenmerken van de variabelen is te vinden in de volgende hoofdstukken waarin tevens de resultaten worden beschreven.

\section{Eerste deelonderzoek: de loopbaan-enquête}

Onder ouderejaars studenten werd een schriftelijke enquête afgenomen over hun toekomstige loopbaan. De enquête is erop gericht inzicht te krijgen in de voorbereiding van studenten op de arbeidsmarkt. Wat zijn de kenmerken van de voorbereidingsfase? Sollicitatiegedrag wordt cruciaal geacht in de voorbereidingsfase. In hoeverre zijn kennis van de arbeidsmarkt, doelgerichtheid, persoonlijkheidskenmerken van de student en de persoonlijke situatie van invloed 
op sollicitatiegedrag? Het eerste deelonderzoek geeft antwoord op deze vragen.

\section{steekproef}

Dit onderzoek werd gehouden onder studenten van de Faculteit der Gezondheidswetenschappen van de Rijksuniversiteit Limburg. Alle vierde, vijfde en zesdejaars studenten gezondheidswetenschappen in mei 1989 werden als proefpersoon gekozen voor het eerste deelonderzoek. Het betrof in totaal 312 studenten, waarvan 223 studenten de loopbaanenquête hadden ingevuld en geretourneerd, na een schriftelijk rappel. Dit was een respons van $72 \%$. In tabel 3.1 wordt de verdeling van de totale groep studenten over de studiejaren vergeleken met de verdeling binnen de steekproef. Per jaargroep staat het responspercentage aangegeven.

Tabel 3.1: Studiejaar van de totale groep studenten en van de steekproef

\begin{tabular}{lrrrr}
\hline & totaal $(312)$ & \multicolumn{2}{c}{ steekproef (223) } & respons \\
\cline { 2 - 5 } & $190(61 \%)$ & $146(65 \%)$ & $77 \%$ \\
vierdejaars & $99(32 \%)$ & $55(25 \%)$ & $56 \%$ \\
vijfdejaars & $20(6 \%)$ & 19 & $(9 \%)$ & $95 \%$ \\
zesdejaars & $3(1 \%)$ & 3 & $(1 \%)$ & $100 \%$ \\
zevendejaars & & & & \\
\hline
\end{tabular}

Een vrijwel volledige respons werd verkregen bij de zesdejaars en zevendejaars. De respons van de vierdejaars was redelijk, namelijk $77 \%$. Van de vijfdejaars studenten was de respons in verhouding het laagst en bedroeg $56 \%$. De groep respondenten bestond uit 167 vrouwen en 56 mannen. Deze vrouw/man verhouding van $75 \% / 25 \%$, kwam overeen met het aantal vrouwelijke en mannelijke studenten bij gezondheidswetenschappen. De leeftijd varieerde van 22 tot 48 jaar. De gemiddelde leeftijd was 25 jaar. Mannelijke respondenten waren gemiddeld ouder dan de vrouwelijke respondenten.

De opleiding gezondheidswetenschappen kent zeven verschillende afstudeerrichtingen: beleid en beheer van de gezondheidszorg, gezondheidsvoorlichting, verplegingswetenschap, theorie van de gezondheidswetenschappen, geestelijke gezondheidkunde, bewegingswetenschappen en biologische gezondheidkunde. Een kleine groep studenten volgde twee afstudeerrichtingen. De verdeling van de respondenten over de verschillende afstudeerrichtingen kwam goed overeen met de werkelijke verdeling van studenten over de studierichtingen, zie tabel 3.2. 


totaal steekproef

$\begin{array}{lrr}\text { Beleid en beheer } & 22 & 22 \\ \text { GVO } & 17 & 17 \\ \text { Verplegingswetenschap } & 8 & 7 \\ \text { Theorie der GW } & 2 & 1 \\ \text { Geestelijke gezondheidkunde } & 23 & 21 \\ \text { Bewegingswetenschappen } & 11 & 10 \\ \text { Biologische gezondheidkunde } & 17 & 14 \\ \text { combinatie van studies } & -- & 6 \\ \text { onbekend } & -- & 2\end{array}$

Bij de afstudeerrichtingen geestelijke gezondheidkunde en biologische gezondheidkunde was er een verschil van enkele procenten. De groep studenten die twee afstudeerrichtingen volgde, was als zodanig niet bekend binnen de totale populatie. Ze stond geregistreerd bij één van de afstudeerrichtingen.

We kunnen zeggen dat de steekgroep representatief was voor de totale populatie, wat betreft de man/vrouw verhouding en de verdeling over de afstudeerrichtingen. In de verdeling over de studiejaren zijn de vijfdejaarsstudenten ondervertegenwoordigd.

\section{onderzoeksinstrument}

De loopbaanenquête bestond uit vier onderdelen. In het eerste gedeelte werd informatie verzameld over de persoon: personalia, gevolgde vooropleiding, eerdere werkervaring, gevolgde afstudeerrichting en de studieduur. Het tweede gedeelte betrof de toekomstige werksituatie. Kenmerken van de gewenste baan en de verwachtingen ten aanzien van de toekomstige werksituatie kwamen hierbij aan de orde. De voorbereiding op de werksituatie kwam in dit onderdeel eveneens aan bod. Het derde gedeelte betrof de aansluiting van de opleiding op het toekomstige beroep. De verwachte aansluiting van kennisaspecten en vaardigheden op de toekomstige baan kwamen hierbij aan de orde. Het vierde gedeelte van de enquête had betrekking op de loopbaanplannen.

\section{procedure}

Een groep ouderejaars studenten werd gekozen als proefpersoon voor het eerste deelonderzoek. Deze groep studenten zou mogelijk op korte termijn afstuderen en derhalve gevolgd kunnen worden tijdens de periode van de overgang van de opleiding naar de arbeidsmarkt. De studenten werden schriftelijk benaderd tijdens de voortgangstoets. Dit is een centraal toetsmoment waaraan vrijwel alle studenten deelnemen. Na een mondelinge aankondiging van de voorzitter van de examencommissie vonden de studenten de loopbaan- 
enquête met een begeleidende brief bij hun tentamenpapieren. De meeste studenten vulden de loopbaanenquête in onmiddellijk na afloop van de toets. Bij de keuze van dit meetmoment deed zich echter een probleem voor; vijfde-, zesde- en zevendejaars studenten namen niet of nauwelijks deel aan de voortgangstoets. Deze groep werd na afloop schriftelijk benaderd. Degenen die de loopbaanenquête niet retourneerden, ontvingen een rappel en werden verzocht alsnog mee te doen aan het onderzoek.

\section{Tweede deelonderzoek: vragenlijsten en psychologische tests}

Rond de periode van het afstuderen werd de groep respondenten van het eerste deelonderzoek opnieuw benaderd om enkele vragenlijsten en psychologische tests in te vullen. Het tweede deelonderzoek is gericht op het verkrijgen van inzicht in de fase van baan verwerven. Relevante concepten van deze fase zijn arbeidsmarktgerichtheid, sollicitatievaardigheden, persoonlijkheidskenmerken en aspecten van de persoonlijke situatie. Met name de gegevens over het al dan niet hebben van een baan, sollicitatievaardigheden en persoonlijkheidskenmerken werden in dit deelonderzoek verzameld.

\section{steekproef}

De respondenten van het eerste deelonderzoek werden opnieuw benaderd in mei 1990. Een gedeelte van hen was toen al afgestudeerd en op zoek naar een baan. Een enkeling werkte op dat moment in de eerste baan. Van de 223 personen hadden er 181 deelgenomen aan het tweede deelonderzoek, na een schriftelijk en telefonisch rappel. Dit was een respons van $81 \%$. De verhouding van mannen en vrouwen die deelnamen aan het tweede deelonderzoek was 1:3. 46 mannen en 135 vrouwen namen deel aan het onderzoek. Deze verhouding is gelijk aan het aantal mannen en vrouwen dat de studie gezondheidswetenschappen volgt.

De verdeling over studiejaren is weergegeven in de volgende tabel. De verdeling is nagenoeg gelijk aan de verdeling van de steekproef in het eerste deelonderzoek.

Tabel 3.3: Studiejaar van de studenten $(n=181)$

frequentie percentage

$\begin{array}{lrr}\text { vierde jaars } & 116 & 64 \\ \text { vijfdejaars } & 48 & 27 \\ \text { zesdejaars } & 15 & 8 \\ \text { zevendejaars } & 2 & 1 \\ \text { totaal } & 181 & 100\end{array}$




\section{onderzoeksinstrumenten}

Rond het tijdstip van afstuderen is een aantal vragenlijsten en psychologische tests voorgelegd:

1. een vragenlijst Persoonlijke gegevens

2. de lijst Persoonlijke kwaliteiten en PGO

3. de Prestatie-Motivatie Test

4. de Nederlandse Persoonlijkheidsvragenlijst.

Een vragenlijst Persoonlijke Gegevens was opgenomen om de informatie over de respondenten actueel te houden. Gevraagd werd bijvoorbeeld naar een adres waar men in de nabije toekomst te bereiken zou zijn, eventueel het adres van de ouders. Verder werd gevraagd wanneer men denkt af te studeren. Als men afgestudeerd was, dan werd geïnformeerd naar de huidige werkzaamheden en sinds wanneer die werden vervuld.

In de vragenlijst Persoonlijke kwaliteiten en Probleemgestuurd onderwijs, gaven studenten aan in hoeverre zij over verschillende vaardigheden en kwaliteiten beschikken, die zij zich gedurende de studie eigen hebben gemaakt en die in de werksituatie van belang zijn. Tevens makkten zij een schatting van de bijdrage van het PGO aan de verworven kwaliteiten. De vragenlijst bestond uit 46 beweringen waarin een bepaalde vaardigheid of kwaliteit staat beschreven. Bijvoorbeeld: $/ k$ kan in een groep leidinggeven, of $/ k$ kan me snel inwerken in een nieuw onderwerp. Elke bewering werd twee keer gescoord op een vijfpuntsschaal met de volgende vragen: 1 . In hoeverre beschikt u over de betreffende kwaliteit? 2. In hoeverre heeft het PGO-systeem hieraan bijgedragen? In twee open vragen aan het slot werd gevraagd naar andere positieve en negatieve effecten van probleem gestuurd onderwijs.

De vragenlijst is ontwikkeld door een analyse te maken van de kenmerken van PGO en deze kenmerken te vertalen naar vaardigheden en kwaliteiten die van een student worden verwacht bij deze vorm van onderwijs. Hierbij werd gebruik gemaakt van gegevens uit de literatuur (Drop \& Post, 1990; Barrows, 1980; Schmidt, 1993) en van een panel van deskundigen. Zo zijn clusters van kwaliteiten ontstaan die zijn uitgewerkt in 46 beweringen. Probleemoplossend vermogen, planmatig gedrag, en leidinggevende vaardigheden zijn onafhankelijke variabelen in de fase van baan verwerving.

De Prestatie-MotivatieTest (PMT) werd afgenomen evenals de Nederlandse Persoonlijkheidsvragenlijst (NPV). De PMT bestaat uit 90 items die zijn ondergebracht in drie schalen: de P-schaal voor het prestatiemotief, de F- schaal voor de negatieve faalangst en de $F+$ schaal voor de positieve faalangst. Alleen de P-schaal wordt in het onderzoek gebruikt als de variabele prestatiegerichtheid. Onder prestatiemotief wordt verstaan een relatief stabiele persoonlijkheidsdispositie die in specifieke situaties leidt tot presteren; presteren in de zin van excelleren in taaksituaties, excelleren zowel in de ogen van anderen als in de ogen van zichzelf (met het accent op zichzelf). Het prestatiemotief wordt geactualiseerd in die taaksituaties die een uitdaging vormen voor de persoon, dat wil zeggen die hem of haar in de gelegenheid stellen om te excelleren (Hermans, 1976). 
De Nederlandse Persoonlijkheidsvragenlijst (NPV) is een breedopgezette persoonlijkheidsvragenlijst die in uiteenlopende praktijkgebieden bruikbaar is en die behoorlijke testtechnische eigenschappen heeft, aldus Luteijn (1974). De NPV bestaat uit 133 items die zijn ondergebracht in zeven schalen: de Inadekwatie-schaal (IN-schaal), de Sociale Inadekwatie-schaal (SI-schaal), de Rigiditeit-schaal (RG-schaal), de Verongelijktheid-schaal (VE-schaal), Zelfgenoegzaamheid-schaal (ZE-schaal), Dominantie-schaal (DO-schaal) en de Zelfwaardering-schaal ( $Z W$-schaal). Sociale vaardigheden, gemeten met de Sociale Inadekwatie-schaal, en zelfwaardering zijn als onafhankelijke variabelen in het onderzoek betrokken.

De items van de Sociale Inadekwatie-schaal (SI-schaal) verwijzen naar het vermijden van of het zich ongelukkig voelen in sociale contacten. De items uit de Zelfwaardering-schaal ( $Z W$-schaal) verwijzen naar een positieve instelling ten opzichte van werken, veranderbaar en goed aangepast zijn. (Luteijn et al., $1985)$.

\section{procedure}

De respondenten van het eerste deelonderzoek werden een jaar later opnieuw benaderd voor een vervolgonderzoek. Dit onderzoek bestond uit enkele vragenlijsten en twee psychologische tests die aan de respondenten werden toegestuurd. Een korte vragenlijst diende om te achterhalen of de studenten inmiddels waren afgestudeerd en of ze een betaalde baan hadden. In de vorige paragraaf werden de onderzoeksinstrumenten beschreven. Bij dit deelonderzoek werden de non-respondenten intensiever benaderd door middel van een schriftelijke herinnering en een telefonisch rappel. Bij een aantal mensen hield de non-respons verband met een bezwaar tegen het invullen van de psychologische tests. Hen werd verzocht in dat geval de andere vragenlijsten in te vullen en terug te sturen.

\section{Derde deelonderzoek: het carrière-interview}

Het afnemen van een aantal interviews met afgestudeerden die werkzaam zijn in hun eerste baan, is erop gericht inzicht te geven in de factoren die een rol spelen in de fase van de eerste werkervaringen en de fase van het ervaren van succes in de werksituatie.

Verondersteld wordt dat cognities, omgevingskenmerken, overgangskenmerken en functiekenmerken van invloed zijn op de eerste werkervaringen. Het ervaren van succes zal mogelijk worden beïnvloed door functiekenmerken, zelfmanagement, loopbaankenmerken en opleidingsaspecten. Deze onderwerpen kwamen dan ook aan de orde in de interviews.

\section{steekproef}

In 1991/1992 werden interviews afgenomen bij een steekproef van de respondenten van het tweede deelonderzoek. Uiteindelijk zijn 37 personen ge- 
interviewd: 21 vrouwen en 16 mannen. De meeste (62\%) waren ruim een jaar werkzaam in de functie, $31 \%$ was korter dan een jaar in dienst, maar langer dan zes maanden, slecht $6 \%$ was korter dan 6 maanden aan het werk.

\section{onderzoeksinstrument}

Tijdens de eerste periode in de baan werd het carrière-interview afgenomen bij werkenden. Doel van dit interview was het verkrijgen van informatie over ervaringen in de eerste baan als afgestudeerde. Daarnaast werd stilgestaan bij de solicitatieperiode en de aansluiting van de opleiding op de eerste baan. Het interview nam ongeveer anderhalf uur in beslag. Het eerste gedeelte had betrekking op de sollicitatieperiode. Ingegaan werd op de duur van de sollicitatieperiode en de aanpak van het solliciteren. Verder werd besproken of de ervaringen in deze periode achteraf gezien overwegend positief of negatief waren. Het tweede gedeelte betrof de ervaringen in de eerste baan. Achtereenvolgens kwamen aan bod de eerste maanden in de baan, waarbij werd ingegaan op positieve en negatieve ervaringen en de manier van omgaan hiermee; de verwachtingen die men had over de functie, het plannen van de werkzaamheden en de inwerkperiode. Daarna kwam aan de orde hoe de huidige werkzaamheden verlopen, welke mensen in de organisatie belangrijk zijn en of men normen en waarden in de organisatie herkent. Verder werd besproken in hoeverre men succes ervaart in het werk en welke ideeën men heeft over de toekomstige loopbaan. In het laatste gedeelte van het interview kwam de aansluiting van de opleiding op de functie aan bod. In hoeverre zijn kennis en vaardigheden die in de opleiding zijn geleerd, bruikbaar voor de baan?

\section{procedure}

Het derde deelonderzoek betrof een aantal interviews met werkenden. Bij de keuze van de steekproef voor de interviews werden de volgende factoren betrokken. In de steekproef zou de man/vrouw verhouding gelijk moeten zijn aan de verhouding binnen de totale groep. De verhouding tussen de afstudeerrichtingen zou eveneens vergelijkbaar moeten zijn met de oorspronkelijke groep. Tegelijkertijd vonden we het belangrijk dat in de steekproef zowel werkenden zijn opgenomen die korte tijd na afstuderen een baan hadden gevonden als afgestudeerden die niet zo snel waren geslaagd een baan te krijgen. De steekproef werd in eerste instantie aselect samengesteld. Daarna werd gekeken of bij deze groep werd voldaan aan de gestelde randvoorwaarden, zoals de verhouding mannen en vrouwen, verdeling over de afstudeerrichtingen en de verhouding werkenden en werklozen. Op basis hiervan werd een kleine correctie toegepast. Dit leverde een groep op van 30 personen. Uiteindelijk is bij 27 personen een interview afgenomen. De reden voor dit kleinere aantal feitelijk afgenomen interviews is van praktische aard; met sommige personen lukte het niet tot een afspraak te komen. Deze groep werd aangevuld met tien afgestudeerden van andere universiteiten. 


\section{Vierde deelonderzoek: vergelijking van PGO met traditioneel onderwijs}

Het overgangsproces van de opleiding naar de arbeidsmarkt is onderzocht bij studenten en afgestudeerden van de Faculteit der Gezondheidswetenschappen. Deze studenten hebben hun opleiding gevolgd door middel van probleemgestuurd onderwijs. Heeft deze onderwijsvorm geleid tot een andere en misschien wel betere voorbereiding op de arbeidsmarkt? Om inzicht te krijgen in de persoonlijke kwaliteiten van studenten en de relatie met het gevolgde onderwijs, werd de vragenlijst Persoonlijke kwaliteiten en PGO aangepast voor studenten die een meer traditioneel onderwijssysteem hebben gevolgd.

\section{steekproef}

Een groep psychologie studenten van de KU te Nijmegen werd benaderd om hun medewerking te verlenen aan het onderzoek. Zij volgden een doctoraal vak, dat ook veel werd gekozen door bijvakstudenten. De groep was dan ook divers.

Uiteindelijk hebben 31 studenten de vragenlijst Persoonlijke kwaliteiten en onderwijs, ingevuld. Deze groep bestaat uit 8 mannen (26\%) en 23 vrouwen $(74 \%)$. De meeste studenten (23) studeren arbeids- en organisatiepsychologie, andere studierichtingen zijn communicatiewetenschap ( 3 ), bedrijfscommunicatie (3), technische bedrijfskunde (1) en cognitiewetenschap (1).

Een groep van 7 studenten $(23 \%)$ heeft een vooropleiding op HBO-niveau voltooid.

\section{onderzoeksinstrument}

De vragenlijst was een aangepaste versie van de vragenlijst Persoonlijke kwaliteiten en PGO. De nieuwe vragenlijst bestond eveneens uit 46 beweringen waarin een vaardigheid of kwaliteit stond beschreven. Bijvoorbeeld: Ik kan in een groep leidinggeven, of $l k$ kan me snel inwerken in een nieuw onderwerp. Elke bewering werd twee keer gescoord op een vijfpuntsschaal. De tweede vraag was aangepast op de nieuwe doelgroep. Het betrof de volgende vragen: 1 . In hoeverre beschikt u over de betreffende kwaliteit? 2. In hoeverre heeft het onderwijs hieraan bijgedragen? In twee open vragen aan het slot, werd gevraagd naar andere positieve en negatieve effecten van het gevolgde onderwijs.

Uiteindelijk zijn de volgende clusters van vaardigheden vergeleken voor de studenten die traditioneel onderwijs hebben gevolgd en de PGO-studenten: planmatig gedrag, probleemoplossend vermogen, groepsdynamica en leidinggeven.

\section{procedure}

Gekozen is voor een groep studenten die eveneens een sociaal wetenschappelijke opleiding volgt maar dan aan een andere universiteit met een ander, meer traditioneel onderwijssysteem. De studenten volgen een doctoraal vak in de 
psychologie als onderdeel van de hoofdrichting of als bijvak, de steekgroep was derhalve divers. Tijdens de pauze van een college, werd een korte toelichting gegeven op het onderzoek en medewerking gevraagd. Om onverklaarbare redenen was het college op de betreffende dag zeer slecht bezocht. De respons was dan ook erg laag. Besloten werd om een vragenlijst bij te voegen bij het tentamen, dat korte tijd later zou plaatsvinden. Dit leverde uiteindelijk een acceptabele respons op van 31 vragenlijsten.

\section{Samenvatting}

In dit hoofdstuk wordt verslag gedaan van de opzet van de vier deelonderzoeken waarop dit proefschrift is gebaseerd. De relatie met de onderzoeksvragen is bij elk deelonderzoek aangegeven. In figuur 4 is de opzet schematisch weergegeven. De metingen 1, 2 en 3 zijn longitudinaal verricht. Het vierde deelonderzoek betreft een vergelijking tussen de studenten die deelnamen aan het tweede deelonderzoek en studenten van een andere universiteit. In de volgende hoofdstukken worden de resultaten gepresenteerd.

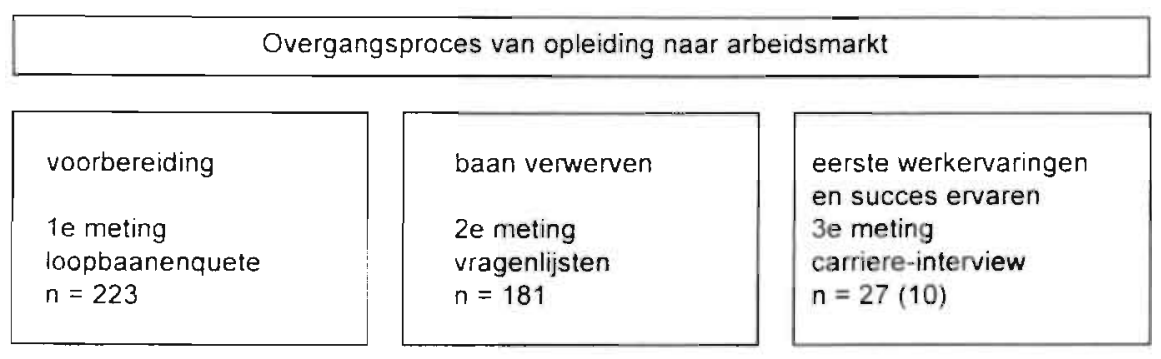

Vergelijking PGO en traditioneel Onderwijs

4e deelonderzoek

kwaliteiten-lijst

rol van onderwijs

$n=31 / n=181$

Figuur 4: De onderzoeksopzet 



\section{4}

\section{Voorbereidingsfase}

Wanneer studenten zich in de eindfase van de studie bevinden, mogen we verwachten dat zij zich voorbereiden op de arbeidsmarkt. In hoofdstuk 2 zijn de relevante variabelen beschreven uit de voorbereidingsfase. Het belangrijkste kenmerk van de voorbereidingsfase is sollicitatiegedrag. Hieronder verstaan we activiteiten op het gebied van arbeidsmarktoriëntatie als voorbereiding op het meer gerichte solliciteren. We gaan ervan uit dat de mate waarin sollicitatiegedrag wordt vertoond, afhangt van verschillende factoren. De kennis die men heeft van de arbeidsmarkt lijkt hierbij van belang. Studenten zouden een duidelijk beeld moeten hebben van de functies waarvoor zij in aanmerking komen en wat het betekent om in een dergelijke baan werkzaam te zijn. Werkervaring die is opgedaan voorafgaand of tijdens de studie en stageervaringen kunnen bijdragen aan de kennis van de arbeidsmarkt. Wanneer werkervaring is opgedaan zou dit van invloed kunnen zijn in de voorbeidingsfase. De stage kan ook worden beschouwd als werkervaring. De student krijgt hierbij een bepaalde opdracht en draagt de verantwoordelijkheid voor het goed vervullen van de taak. Ook deze ervaring kan relevant zijn in de voorbereidingsfase.

Een goed inzicht in eigen kwaliteiten en mogelijkheden is een voorwaarde om meer gerichte toekomstplannen te maken. Doelgerichtheid speelt hierbij een belangrijke rol: in staat zijn om doelen te formuleren en deze op planmatige wijze te benaderen. Doelgerichtheid wordt gezien als een relevante vaardigheid in de voorbereiding op de arbeidsmarkt (Hall, 1976; Schreurs \& Van de Pol, 1985). Doelgerichtheid komt ook tot uiting in de concrete plannen die men heeft na afronding van de studie. Sommigen hebben een duidelijk en concreet doel voor ogen, voor andere studenten zijn de plannen algemeen en vaag. De persoonlijkheid van de studenten zal ook een rol spelen bij de voorbereiding. In hoeverre is men prestatiegericht? lemand met een hoge prestatiemotivatie zal waarschijnlijk in sterkere mate nastreven een goede baan te krijgen na afstuderen. Self-efficacy lijkt eveneens een relevant persoonlijkheidskenmerk. Self-efficacy heeft betrekking op de verwachting dat men een bepaalde taak tot een goed einde brengt. Hieruit blijkt een vertrouwen in de eigen capaciteiten om mogelijke problemen te kunnen oplossen. (Schwarzer, 1992). Wanneer men erop vertrouwt de gewenste baan te kunnen krijgen, zou dit een rol kunnen spelen in de voorbereiding op de arbeidsmarkt. Een inschat- 
ting van het probleemoplossend vermogen om onverwachte moeilijkheden te kunnen oplossen, is eveneens van belang.

Bepaalde persoonskenmerken lijken relevant in de voorbereidingsfase. De leeftijd kan een rol spelen. Een jongere student zal mogelijk minder haast maken om aan de slag te komen dan iemand die al een eerdere opleiding heeft gevolgd. Het studiejaar zou van belang kunnen zijn. Vijfde- en zesdejaars studenten staan mogelijk anders in de voorbereidingsfase dan vierdejaars studenten. De voorbereiding van mannen en vrouwen zou kunnen verschillen. Soms blijkt immers dat vrouwen zich uitgebreider oriënteren op de arbeidsmarkt (Stuurman, 1993; Broekmate \& Schreurs, 1994).

Hoe zijn deze variabelen geoperationaliseerd? Hieronder volgt een beschrijving van de variabelen en een schema met de statistische kenmerken. In dit schema zijn opgenomen de gemiddelde waarde van de variabelen, de standaarddeviatie, de minimum- en maximumwaarde die in de populatie zijn aangetroffen en het aantal respondenten. De waarden die de variabele kan aannemen is weergegeven bij de beschrijving van de variabelen. Alle variabelen zijn afkomstig van de eerste meting, de loopbaanenquête, met uitzondering van de variabelen planmatig gedrag, prestatiegerichtheid en probleemoplossen. Deze zijn verzameld tijdens de tweede meting. Het gaat hierbij om relatief stabiele persoonlijkheidskenmerken.

\section{Variabelen uit de voorbereidingsfase}

1. Sollicitatiegedrag. Deze variabele heeft betrekking op het al dan niet solliciteren van studenten. Gemeten wordt of men al aan het solliciteren is, daarmee binnenkort wil beginnen of dat men niet van plan is op korte termijn te solliciteren. De waarde die de variabele kan aannemen varieert van 1 tot 5 .

2. Werkvaring. Hierbij is gevraagd naar relevante werkervaring voorafgaand aan de studie of tijdens de studie. Eerdere werkervaring kan van belang zijn bij de voorbereiding. Men heeft een duidelijker beeld van wat het betekent om te werken. Werkervaring wordt beschouwd als een indicatie voor het beschikken over algemene beroepsinformatie. Dit is een dichotome variabele die de waarde 1 of 2 kan aannemen.

3. Stage-ervaringen. Deze variabele geeft aan in hoeverre de stageperiode belangrijk is geweest voor de oriëntatie op de arbeidsmarkt. Het betreft twee items uit een lijst van informatiebronnen over de toekomstige werksituatie. De betrouwbaarheid van deze subschaal is vastgesteld door middel van Cronbach's alpha. De waarde van Cronbach's alpha $=.75$. De betrouwbaarheid is dan ook acceptabel. De waarde van de variabele kan variëren van 1 tot 3 .

4. Planmatig gedrag. Onder planmatig gedrag verstaan we het doelgericht aanpakken van activiteiten. Een efficiënt gebruik maken van de beschikbare tij valt hieronder. Planmatig gedrag wordt gemeten door middel van een schaal in de vragenlijst Persoonlijke Kwaliteiten en PGO. De subschaal bestaat 
uit 10 items. De betrouwbaarheid van deze subschaal is hoog, Cronbach's alpha $=.83$. De waarde van de variabele kan variëren van 1 tot 5 .

5. Plannen na afstuderen. De voorbereiding wordt mede gestuurd door de concrete plannen die de student heeft na afstuderen. De plannen na afstuderen variëren van het willen werken in een betaalde functie tot het willen volgen van een andere opleiding of het ontbreken van een plan na afstuderen. De variabele heeft een waarde variërend van 1 tot 4 .

6. Self-efficacy. Deze variabele geeft aan of men verwacht de gewenste baan te krijgen. Het blijkt dat degenen die verwachten een bepaalde taak goed te volbrengen, vaker in staat zijn dit daadwerkelijk te realiseren. De variabele kan de waarde van 1 tot 3 aannemen.

7. Prestatiegerichtheid. Prestatiegerichtheid is gemeten als de somscore op de subschaal voor het prestatiemotief van de Prestatiemotivatietest. Het prestatiemotief wordt beschouwd als een relatief stabiel persoonlijkheidskenmerk dat leidt tot presteren in specifieke taaksituaties. Het gaat hierbij om het excelleren zowel in de eigen ogen als in de ogen van anderen. De waarde varieert van 0 tot 38 .

8. Probleemoplossend vermogen. Hieronder wordt verstaan het kunnen analyseren en oplossen van problemen met gebruik van informatiebronnen. Een goed inzicht in eigen mogelijkheden valt hier ook onder. Probleemoplossend vermogen wordt gemeten door middel van een subschaal bestaande uit 12 items uit de vragenlijst Persoonlijke Kwaliteiten en PGO. De betrouwbaarheid van deze subschaal is acceptabel; Cronbach's alpha $=.78$. De waarde kan variëren van 1 tot 5 .

9. Leeftijd. Erg jonge studenten kunnen problemen ervaren bij het solliciteren voor bepaalde functies waarbij werkervaring van belang is. Voor oudere sollicitanten geldt eveneens dat bepaalde functies moeilijk toegankelijk zullen zijn.

10. Studiejaar. Met deze variabele wordt het studiejaar aangegeven waarin de student zich bevindt. Het studiejaar varieert van vierdejaars tot zevendejaars studenten. Ouderejaars studenten solliciteren mogelijk intensiever dan jongerejaars studenten.

11. Geslacht. Loopbanen van mannen en vrouwen verschillen in sterke mate. Bekend is dat reeds kort na afstuderen verschillen bestaan tussen mannen en vrouwen in functieniveau en salariëring. Deze verschillen worden daarna alleen maar groter. 


\begin{tabular}{lcccccc}
\hline \multicolumn{1}{c}{ variabele } & gem. & s.d. & min. & max. & $\mathrm{n}$ & meting \\
\hline 1. sollicitatiegedrag & 3.63 & 1.30 & 1 & 5 & 180 & 1 \\
2. werkervaring & - & - & 1 & 2 & 221 & 1 \\
3. stage-ervaringen & 2.51 & .66 & 1.00 & 3.00 & 191 & 1 \\
4. planmatig gedrag & 4.01 & .50 & 2.40 & 5.00 & 162 & 2 \\
5. plannen na afstuderen & 2.61 & .85 & 1 & 4 & 216 & 1 \\
6. self-efficacy & 1.95 & .96 & 1 & 3 & 218 & 1 \\
7. prestatiegerichtheid & 20.44 & 7.15 & 3 & 38 & 163 & 2 \\
8. probleemoplossen & 3.74 & .38 & 2.50 & 4.83 & 150 & 2 \\
9. leeftijd & 25.17 & 3.89 & 22.00 & 48.00 & 223 & 1 \\
10. studiejaar & 4.43 & .77 & 3 & 7 & 223 & 1 \\
11. geslacht & - & - & 1 & 2 & 223 & 1 \\
& & & & & & \\
\hline
\end{tabular}

\section{Kenmerken van de voorbereidingsfase}

Sollicitatiegedrag is een kernvariabele in de voorbereidingsfase en is gedefinieerd als afhankelijke variabele in deze fase. Onder sollicitatiegedrag verstaan we de houding ten aanzien van solliciteren. In verschillende intensiteit zijn studenten bezig met solliciteren. De verschillende mogelijkheden zijn benoemd en variëren van 'niet willen solliciteren' tot 'bezig zijn met solliciteren'. De afstand tussen de verschillende waarden die de variabele kan aannemen, wordt als gelijk beschouwd.

In welke mate solliciteren studenten in de laatste fase van hun studie? In tabel 4.2 staan de frequenties van sollicitatiegedrag, uitgesplitst naar sekse.

Tabel 4.2: Sollicitatiegedrag $(n=180)$

\begin{tabular}{lrrr}
\hline & mannen & vrouwen & \multicolumn{1}{c}{ totaal } \\
\cline { 2 - 4 } & & $12(9 \%)$ & $17(10 \%)$ \\
1. wil niet solliciteren & $(0 \%)$ & $13(9 \%)$ & $13(7 \%)$ \\
2. andere studie & $6(15 \%)$ & $39(28 \%)$ & $45(25 \%)$ \\
3. wil later beginnen & $15(37 \%)$ & $37(26 \%)$ & $52(29 \%)$ \\
4. binnenkort beginnen & $14(35 \%)$ & $39(28 \%)$ & $53(29 \%)$ \\
5. bezig met solliciteren & & & \\
$x^{2}=12.09, \mathrm{df}=3, \mathrm{p}<.01$ & & & \\
\hline
\end{tabular}


In de eindfase van de opleiding is $29 \%$ van de studenten bezig met solliciteren, eveneens $29 \%$ wil hier op korte termijn mee beginnen. Een grote groep van $42 \%$ blijkt geen plannen te hebben om op korte termijn te solliciteren. Een deel hiervan wil een andere studie volgen, een andere groep wil niet solliciteren om andere redenen, en eenvijfde van de studenten wil later solliciteren omdat het afstuderen naar hun idee te ver weg is. Vrouwen zijn relatief vaker geneigd het solliciteren nog enige tijd uit te stellen. Mannen zijn al vaker bezig met solliciteren of willen daarmee op korte termijn beginnen.

\section{kennis van de arbeidsmarkt}

Op veel verschillende manieren kan kennis van de arbeidsmarkt worden opgedaan. Een belangrijk onderdeel is kennis van organisaties: in de zin van weten wat het inhoudt om in een organisatie te werken. Dit komt men vooral aan de weet door het daadwerkelijk te ervaren in een betaalde baan of tijdens de stage. We verwachten dan ook dat kennis van de arbeidsmarkt wordt verkregen door middel van werkervaring en tijdens de stage. Een eerder gevolgde opleiding kan hierbij ook een rol spelen. Meestal zal tijdens die opleiding ook een stage zijn vervuld. Soms zijn de beperkte arbeidsmarktperspectieven van de betreffende opleiding een reden om een vervolgopleiding te kiezen.

In welke mate hebben studenten gezondheidswetenschappen werkervaring opgedaan voorafgaand aan de studie of tijdens de studie? In tabel 4.3 wordt hiervan een overzicht gegeven. Het blijkt dat iets meer dan de helft van de studenten relevante werkervaring heeft, namelijk $52 \%$. Dit geldt in hogere mate voor de mannen dan voor de vrouwen (57\% versus $50 \%)$. Dit verschil is niet significant. In tabel 4.4 staat beschreven welke functies ze hebben vervuld. In meer dan de helft van de gevallen gaat het om student-assistentschappen voor onderwijs- of onderzoekstaken. Hierbij zijn mannen in verhouding vaker onderzoeks- en studentassistent geweest en hebben vrouwen vaker de rol van studenttutor en -trainer vervuld. Bijna eenvierde van de ervaringen heeft betrekking op de verpleging en hulpverlening.

Tabel 4.3: Werkervaring $(n=221)$

\begin{tabular}{llll}
\hline & mannen & vrouwen & totaal \\
\cline { 2 - 4 } & $24(43 \%)$ & $82(50 \%)$ & $106(48 \%)$ \\
geen werkervaring & $32(57 \%)$ & $83(50 \%)$ & $115(52 \%)$ \\
wel werkervaring & & & \\
$x^{2}=.78, \mathrm{df}=1$, n.s. & & \\
\hline
\end{tabular}

De ervaringen die tijdens de stage zijn opgedaan, worden ook beschouwd als een indicator van kennis van de arbeidsmarkt. Aan studenten is gevraagd in hoeverre de stage van belang is geweest voor de arbeidsmarktoriëntatie. De 
scores op deze variabele lopen van 1 tot 3 , waarbij 1 wil zeggen dat de stage een onbelangrijke rol heeft gespeeld en 3 wil zeggen dat de stage erg belangrijk was. Het blijkt dat bijna de helft van de studenten de stage erg belangrijk vond voor de oriëntatie op de arbeidsmarkt.

Tabel 4.4: Type werkervaring $(n=118)$

\begin{tabular}{lrrr}
\hline & mannen & vrouwen & totaal \\
\cline { 2 - 4 } & $12(37 \%)$ & $21(25 \%)$ & $33(28 \%)$ \\
Onderzoeks-/studentassistent & $5(15 \%)$ & $25(29 \%)$ & $30(25 \%)$ \\
Studenttutor/-trainer & $7(21 \%)$ & $15(18 \%)$ & $22(19 \%)$ \\
Verpleegkundige & $1(3 \%)$ & $14(17 \%)$ & $15(13 \%)$ \\
Hulpverlening/maatsch.werk & $1(3 \%)$ & $3(3 \%)$ & $4(3 \%)$ \\
Stage & $7(21 \%)$ & $7(8 \%)$ & $14(12 \%)$ \\
Overig & & &
\end{tabular}

$x^{2}=9.98, d f=5$, n.s.

Slechts $12 \%$ van de studenten was van mening dat de stage onbelangrijk was voor hun arbeidsmarktoriëntatie.

In een eerdere opleiding kunnen studenten belangrijke ervaringen hebben opgedaan in relatie tot de arbeidsmarkt. Daarom is geïnventariseerd of men al dan niet een opleiding gevolgd heeft voorafgaand aan de studie gezondheidswetenschappen. Eenzesde van de studenten blijkt een eerdere opleiding te hebben gevolgd op HBO of academisch niveau.

Samenvattend mogen we stellen dat meer dan de helft van de studenten relevante werkervaring heeft, meestal opgedaan als student-assistent. In mindere mate hebben studenten ervaring als verpleegkundige en in de hulpverlening. Mannelijke studenten hebben in verhouding vaker werkervaring opgedaan dan vrouwelijke studenten. De stage wordt door de helft van de studenten als erg belangrijk ervaren als voorbereiding op de arbeidsmarkt. Verder blijkt eenzesde van de studenten een eerder opleiding te hebben afgerond.

\section{doelgerichtheid}

Planmatig gedrag en de plannen die studenten hebben voor de periode na hun afstuderen zijn indicatoren van doelgerichtheid. Onder planmatig gedrag verstaan we het doelgericht benaderen van activiteiten. Planmatig gedrag is gemeten door middel van een subschaal bestaande uit 10 vragen van de lijst Persoonlijke kwaliteiten en PGO. Voorbeelden van deze vragen zijn: Ik ben in staat planmatig te werken, en Ik kan mijn tijd efficiënt gebruiken. In de volgende tabel wordt een frequentieverdeling geven van planmatig gedrag, uitgesplitst naar sekse. 
De verdeling van de respondenten op planmatig gedrag is nogal scheef. Bij niemand ontbreken alle vormen van planmatigheid. Slechts enkelen geven aan in beperkte mate planmatig te zijn. Vrijwel iedereen zit in de bovenste twee categorieën van tamelijk planmatig en erg planmatig.

Tabel 4.5: planmatig gedrag $(n=162)$

\begin{tabular}{lrrr}
\hline & mannen & vrouwen & \multicolumn{1}{c}{ totaal } \\
\cline { 2 - 4 } & $3(8 \%)$ & $4(3 \%)$ & $7(5 \%)$ \\
1. enigszins planmatig & $31(74 \%)$ & $52(46 \%)$ & $83(51 \%)$ \\
2. tamelijk planmatig & $8(19 \%)$ & $64(53 \%)$ & $72(44 \%)$ \\
3. erg planmatig & & & \\
$x^{2}=82.25, d f=2, p=<.001$ & & \\
\hline
\end{tabular}

De helft van de studenten geeft aan tamelijk planmatig te werken. Bijna de helft van de studenten beoordelen zichzelf als erg planmatig. Opvallend is het verschil tussen mannen en vrouwen. Het merendeel van de mannelijke studenten geeft aan tamelijk planmatig te zijn, terwijl de helft van de vrouwen zichzelf als erg planmatig beoordeelt.

Verder is een vraag in de enquête opgenomen over de concrete plannen van de studenten na afstuderen. Niet iedereen is van plan meteen te gaan werken in een betaalde functie. Het merendeel blijkt op zoek te gaan naar een betaalde baan, namelijk $67 \%$. Een kleine groep studenten (6\%) heeft al een baan. Bijna eentiende van de studenten gaat een andere studie volgen. En bijna eenvijfde van de studenten heeft nog geen idee wat men na het afstuderen gaat doen.

Tabel 4.6: Plannen na afstuderen $(n=216)$

\begin{tabular}{lrrr}
\hline & \multicolumn{1}{c}{ mannen } & vrouwen & \multicolumn{1}{c}{ totaal } \\
\cline { 2 - 4 } 1. geen idee & $13(24 \%)$ & $26(16 \%)$ & $39(18 \%)$ \\
2. andere studie & $3(6 \%)$ & $16(10 \%)$ & $19(9 \%)$ \\
3. op zoek naar een baan & $33(62 \%)$ & $112(69 \%)$ & $145(67 \%)$ \\
4. verder werken in huidige baan $4(8 \%)$ & $9(5 \%)$ & $13(6 \%)$ \\
$x^{2}=2.94, \mathrm{df}=3$, n.s. & & & \\
\end{tabular}

Samenvattend kunnen we zeggen dat vrijwel alle respondenten in staat zijn om planmatig te werken. Vrouwelijke studenten geven aan in hogere mate 
planmatig te zijn dan hun mannelijke collega's. Toch heeft bijna eenvijfde van de studenten geen duidelijke plannen voor na het afstuderen. Bijna driekwart van de studenten gaat doelgericht op zoek. naar een baan of heeft al een baan.

\section{persoonlijkheid}

Een drietal relevante variabelen zijn onderscheiden met betrekking tot de persoonlijkheid: self-efficacy, prestatiegerichtheid en probleemoplossend vermogen.

Self-efficacy heeft betrekking op een bepaalde houding of verwachting waardoor de kans groter is dat daadwerkelijk bereikt wordt wat men graag wil. Een sterke verwachting de baan te krijgen waar de voorkeur naar uitgaat zal de kans verhogen dat men die baan ook inderdaad verwerft. Deze verwachting zal er waarschijnlijk toe leiden dat men meer activiteiten onderneemt om dat plan te realiseren. Het sollicitatiegedrag zal dan ook intensiever zijn. De frequentieverdelingen voor het al dan niet verwachten de gewenste baan te krijgen, staan in tabel 4.7 als maat voor self-efficacy.

Tabel 4.7: Verwachting realisatie gewenste baan $\langle n=218$ )

\begin{tabular}{lrrr}
\hline & mannen & vrouwen & totaal \\
\cline { 2 - 4 } weet niet & $20(36 \%)$ & $87(53 \%)$ & $106(48 \%)$ \\
nee & $2(4 \%)$ & $15(9 \%)$ & $17(8 \%)$ \\
$j a$. & $33(60 \%)$ & $62(38 \%)$ & $95(44 \%)$ \\
$x^{2}=8.46, d f=2, p=.01$ & & & \\
\hline
\end{tabular}

Mannen blijken positiever te zijn dan vrouwen; $60 \%$ van de mannen tegenover slechts $38 \%$ van de vrouwen verwacht de loopbaanwensen te realiseren. Vrouwen geven vaker aan niet te weten of hen dit zal lukken; ruim de helft van de vrouwen kiest voor dit antwoord-alternatief.

Prestatiegerichtheid is gemeten met behulp van de Prestatiemotivatietest. Het gaat om de subschaal van het Prestatiemotief. De scores op deze schaal zijn vergeleken met de normscores. Dat levert een verdeling over decielen op, lopend van zeer laag (1) tot zeer hoog (10).

Opvallend is dat relatief hoge aantallen op de laagste twee decielen en relatief kleine aantallen op de hoogste drie decielen voorkomen. Als groep liggen de scores van de respondenten echter dicht bij de scores van de normgroep op het prestatiemotief. De gemiddelde score bedraagt 20.44; de gemiddelde score van mannen bedraagt 17.71 (s.d. 7.08); vrouwen scoren gemiddeld 21.26 (s.d. 6.99); de normgroep voor mannen scoort gemiddeld 21.32; voor vrouwen bedraagt dit 20.83 . Opvallend is de relatief lagere score van man 
nen, zowel ten opzichte van de vrouwelijke respondenten als ten opzichte van de mannen in de normgroep.

Probleemoplossend vermogen kan gezien worden als een persoonlijkheidskenmerk dat van belang is in de voorbereidende fase. Solliciteren kan namelijk ook benaderd worden als een probleem. Dit aspect is gemeten met behulp van een subschaal uit de vragenlijst Persoonlijke kwaliteiten en PGO, waarbij een subjectieve beoordeling wordt gegeven van het eigen probleemoplossend vermogen. De schaal omvat vragen als Problemen oplossen gaat mij gemakkelijk af, en $1 k$ ben in staat oplossingen voor een probleem te vinden die niet voor de hand liggen. De gemiddelde score van 12 items uit de vragenlijst is de waarde voor probleemoplossend vermogen. Uiteindelijk is een indeling gemaakt in vier categorieën, lopend van in beperkte mate aanwezig tot in hoge mate aanwezig.

Vrijwel alle studenten vallen in de hoogste twee categorieën. Viervijfde van de studenten geeft aan te beschikken over een redelijke mate van probleemoplossend vermogen. Eenvijfde zegt te beschikken over een hoge mate van probleemoplossend vermogen. Er zijn geen opmerkelijke verschillen tussen mannen en vrouwen.

Samenvattend kunnen we over de persoonlijkheid van de respondenten zeggen dat minder dan de helft van de respondenten verwacht de baan van hun voorkeur te realiseren. De helft van de studenten is hierover twijfelachtig. Verwachten mannen vaker dat zij erin slagen de gewenste baan te krijgen. Vergeleken met de vrouwelijke respondenten. In het algemeen is de prestatiegerichtheid van de totale groep lager dan gemiddeld. Vrouwen zijn echter in hogere mate prestatiegericht dan mannen. De inschatting van probleemoplossend vermogen is gemiddeld redelijk tot hoog.

\section{persoonlijke situatie}

Het studiejaar van de respondent en de leeftijd worden beschouwd als relevante aspecten van de persoonlijke situatie. Veel studenten doen langer dan vier jaar over hun opleiding niet alleen vanwege de verplichte studieonderdelen maar ook omdat ze extra studieactiviteiten willen ondernemen om zich beter te kwalificeren voor de arbeidsmarkt. Enkele derdejaars studenten zijn in dit onderzoek betrokken omdat ze een doorstroomopleiding volgen met een vrijstelling voor de propaedeuse. Zij zijn dus in feite vergelijkbaar met de reguliere vierdejaars studenten.

In tabel 4.8 staat aangegeven in welk studiejaar de respondenten zitten. Tabel 4.9 geeft een overzicht van de redenen waarom men niet in vier jaar afstudeert. 


\begin{tabular}{|c|c|c|c|}
\hline & mannen & vrouwen & totaal \\
\hline derdejaars & $3(5 \%)$ & $6(4 \%)$ & $9 \quad(4 \%)$ \\
\hline vierdejaars & $34(61 \%)$ & $101(61 \%)$ & $135(61 \%)$ \\
\hline vijfdejaars & $13(23 \%)$ & $43(26 \%)$ & $56(25 \%)$ \\
\hline zesdejaars & $5(9 \%)$ & $15(9 \%)$ & $20 \quad(9 \%)$ \\
\hline zevendejaars & $1 \quad(2 \%)$ & $2(1 \%)$ & $3(1 \%)$ \\
\hline$x^{2}=.54, \mathrm{df}=$ & & & \\
\hline
\end{tabular}

Tabel 4.9: Reden niet binnen vier jaar afstuderen $(n=120)$

\begin{tabular}{lrrr}
\hline & mannen & vrouwen & totaal \\
\cline { 2 - 4 } extra blokken & $1(3 \%)$ & $10(11 \%)$ & $11(9 \%)$ \\
tweede studie & $2(7 \%)$ & $13(14 \%)$ & $15(13 \%)$ \\
stage verlengen & $11(37 \%)$ & $23(26 \%)$ & $34(28 \%)$ \\
anders & $16(53 \%)$ & $44(49 \%)$ & $60(50 \%)$ \\
$x^{2}=3.64, \mathrm{df}=3$, n.s. & & & \\
\hline
\end{tabular}

De helft van de studenten die langer dan vier jaar studeert, volgt extra studieactiviteiten; de helft heeft andere redenen om niet binnen vier jaar af te studeren. Toch worden ook hier vaak extra studieonderdelen genoemd, zoals het volgen van een tweede stage. De gemiddelde leeftijd van de groep respondenten bedraagt 25 jaar. Mannen zijn gemiddeld ouder dan vrouwen.

\section{Relaties tussen kennis van de arbeidsmarkt, doelgerichtheid, persoonlijkheidskenmerken, persoonlijke situatie en sollicita- tiegedrag}

Tijdens de voorbereidingsfase komt het erop aan voorbereidingen te treffen voor het verwerven van een betaalde baan. Hierboven is beschreven in welke mate de relevante onafhankelijke variabelen een rol spelen in de laatste fase van de opleiding. Verondersteld werd dat deze variabelen samenhangen met sollicitatiegedrag. Hierna wordt allereerst de correlatiematrix gepresenteerd van de onafhankelijke variabelen uit de voorbereidingsfase, daarna volgen de correlaties tussen sollicitatiegedrag en de onafhankelijke variabelen. De corre- 
laties tussen de onafhankelijke variabelen en sollicitatiegedrag worden in een aparte tabel gepresenteerd, omdat hierdoor duidelijker zichtbaar wordt welke variabelen in deze fase van belang zijn.

Uit de correlatiematrix van de voorbereidingsfase blijkt dat er een verband is tussen het hebben van werkervaring en leeftijd. Degenen die ouder zijn hebben vaker werkervaring opgedaan, voorafgaand of tijdens de studie. Het betreft waarschijnlijk degenen die een eerdere opleiding hebben gevolgd of eerst een tijd hebben gewerkt alvorens aan de studie te beginnen. Verder blijkt een lichte samenhang tussen het hebben van werkervaring en de concrete plannen die men heeft na de studie. De respondenten met werkervaring zijn vaker van plan meteen te gaan werken na de studie.

Het belang van de stage blijkt samen te hangen met het studiejaar. Hoe verder men met de studie gevorderd is, des te positiever kijkt men terug op de stage. Een verklaring hiervoor is wellicht het feit dat sommige jongerejaars nog geen stage hebben gevolgd.

Planmatig gedrag blijkt samen te hangen met de plannen na afstuderen, met prestatiegerichtheid en probleemoplossen en met geslacht. Dit betekent dat naarmate studenten zichzelf meer planmatig vinden ingesteld zij geneigd zijn concrete plannen te maken voor na de studie. Degenen die aangeven in hoge mate planmatig te zijn, blijken eveneens vaak prestatiegericht te zijn en zeggen te beschikken over een groot probleemoplossend vermogen. In deze groep beoordelen de vrouwen zichzelf in hogere mate als planmatig dan de mannen. De mate van concreetheid van de plannen na afstuderen blijkt sterk samen te hangen met self-efficacy. Degenen die ervan uitgaan dat zij de gewenste baan krijgen, lijken gerichter te plannen om dit te realiseren.

Plannen na afstuderen blijkt eveneens samen te hangen met de persoonlijkheidskenmerken prestatiegerichtheid en probleemoplossend vermogen. Degenen die prestatiegericht zijn, evenals degenen die aangeven te beschikken over een goed probleemoplossend vermogen, lijken gerichtere plannen te ontplooien om te gaan werken in een betaalde baan. Verder is er een verband te zien tussen de plannen na afstuderen en leeftijd. Hoe ouder men is hoe concreter de plannen om te gaan werken in een betaalde baan.

Self-efficacy blijkt samen te hangen met probleemoplossen en leeftijd. Naarmate men ouder is, heeft men sterker het idee de gewenste baan te realiseren; en naar mate men aangeeft te beschikken over een groter probleemoplossend vermogen, heeft men sterker het idee de gewenste baan te kunnen realiseren.

Prestatiegerichtheid vertoont een relatie met probleemoplossend vermogen en met geslacht. De vrouwelijke respondenten blijken in hogere mate prestatiegericht te zijn dan de mannelijke studenten in dit onderzoek.

Verder blijkt er een relatie tussen leeftijd en geslacht. De vrouwelijke respondenten zijn gemiddeld jonger dan hun mannelijke studiegenoten. 


\begin{tabular}{|c|c|c|c|c|c|c|c|c|c|c|}
\hline & 1 & 2 & 3 & 4 & 5 & 6 & 7 & 8 & 9 & 10 \\
\hline 1. werkervaring & 1.00 &. .09 & .13 & $.17^{\circ}$ & .13 & -.01 & .14 & $.28^{\circ}$ & -.04 & -.07 \\
\hline 2. staģe & & 1.00 & -.01 & .15 & -.07 & .00 & .06 & -.06 & $.16^{\circ}$ & -.00 \\
\hline 3. planmatig & & & 1.00 & $.26^{\circ}$ & .07 & $.50^{\cdots}$ & $.38^{\cdots}$ & -.03 & -.10 & $.33^{*}$ \\
\hline 4. plannen & & & & 1.00 & $.28^{\circ}$ & $.23^{\circ}$ & $.21^{\circ}$ & $.16^{\circ}$ & .09 & -.05 \\
\hline 5. self-efficacy & & & & & 1.00 & .09 & $.18^{\circ}$ & $.16^{\circ}$ & .02 & -.14 \\
\hline 6. prestatiegerichtheid & & & & & & 1.00 & $.23^{*}$ & -.07 & .02 & $.21^{\bullet}$ \\
\hline 7. probleemoplossen & & & & & & & 1.00 & -.12 & .08 & -.10 \\
\hline 8. leeftijd & & & & & & & & 1.00 & .00 & $-.21^{*}$ \\
\hline 9. studiejaar & & & & & & & & & 1.00 & -.02 \\
\hline 10. geslacht & & & & & & & & & & 1.00 \\
\hline$l^{*} p \leq .05, * * p \leq .01$ & $* *{ }^{*} \mathrm{p}$ & $\leq .00$ & & & & & & & & \\
\hline
\end{tabular}

Samenvattend: bij de correlatiematrix zijn vooral onderlinge relaties te zien tussen de variabelen met betrekking tot doelgerichtheid, persoonlijkheidskenmerken en geslacht.

In de volgende tabel staan de correlaties weergegeven tussen de onafhankelijke variabelen en sollicitatiegedrag. Er blijkt geen verband te zijn tussen sollicitatiegedrag en de variabelen met betrekking tot kennis van de arbeidsmarkt. Zowel voor de variabele werkervaring als voor stage-ervaringen is geen verband gevonden met sollicitatiegedrag.

Tabel 4.11: Correlaties met sollicitatiegedrag

$\begin{array}{lll}\text { 1. werkervaring } & -.01 & (n=152) \\ \text { 2. stage } & -.05 & (n=134) \\ \text { 3. planrnatig } & .16^{*} & (n=139) \\ \text { 4. plannen } & .61^{* *} & (n=148) \\ \text { 5. self efficacy } & .10 & (n=152) \\ \text { 6. prestatiegerichtheid } & .34^{* *} & (n=138) \\ \text { 7. probleemoplossen } & .08 & (n=129) \\ \text { 8. leeftijd } & .18^{*} & (n=154) \\ \text { 9. studiejaar } & .14 & (n=154) \\ \text { 10. geslacht } & .09 & (n=154)\end{array}$

$(* p \leq .05, * p \leq .01, * * p \leq .001)$

${ }^{1}$ De exacte waarde van $n$ per cel van de correlatiematrix staat vermeld in tabel 1 in de bijlage. 
Wel blijkt er een verband te zijn tussen de plannen na afstuderen en sollicitatiegedrag. Naarmate men meer concrete plannen heeft voor na de studie is men gerichter bezig met solliciteren. Prestatiegerichtheid hangt eveneens samen met sollicitatiegedrag. Naarmate men meer prestatiegericht is, is men vaker bezig met solliciteren. Verder blijkt er een samenhang te zijn tussen leeftijd en sollicitatiegedrag. Degenen die ouder zijn, zijn vaker bezig met solliciteren voor hun afstuderen. Het studiejaar is echter niet van invloed op het sollicitatiegedrag.

Samenvattend: in relatie tot sollicitatiegedrag komen vooral doelgerichtheid en prestatiegerichtheid naar voren. Leeftijd speelt eveneens een rol.

\section{Causale modellering van de voorbereidingsfase}

In de vorige paragrafen zijn de verbanden besproken tussen de verschillende variabelen waarvan verondersteld werd dat zij een rol spelen in de voorbereiding op de overgang naar het beroep. Bij een set eerste-orde correlaties is altijd onduidelijk hoe de bivariate verbanden tot stand gekomen zijn. Dit is vooral een probleem wanneer het vermoeden gerechtvaardigd is dat onder de set van correlaties causale verbanden schuil gaan. Een voorbeeld. Is het zo dat gerichtheid op het leveren van prestaties een rechtstreekse invloed uitoefent op het sollicitatiegedrag; de correlatie tussen beide is .34, of zou het niet eerder zo kunnen zijn dat prestatiegerichtheid in de eerste plaats het maken van concrete plannen bevordert, die op hun beurt het sollicitatiegedrag beinvloeden?

Op deze en andere vragen kan de methode van het modelleren van structurele vergelijkingen structural equations modeling (SEM) een antwoord geven. SEM stelt de onderzoeker in staat een model te formuleren van (causale) samenhangen in een databestand en dit theoretische model te toetsen aan die data. De vergelijkingen in kwestie zijn multipele regressies. Bijvoorbeeld:

Sollicitatiegedrag $=$ Concrete plannen + Error

Concrete plannen $=$ Prestatiegerichtheid + Error

Deze twee vergelijkingen drukken uit wat in het voorgaande als vraag geformuleerd werd; in dit model heeft prestatiegerichtheid geen directe invloed op sollicitatiegedrag, maar wel op het maken van concrete plannen. De variabele concrete plannen heeft wel een directe invloed op sollicatiegedrag, zie figuur 5. 


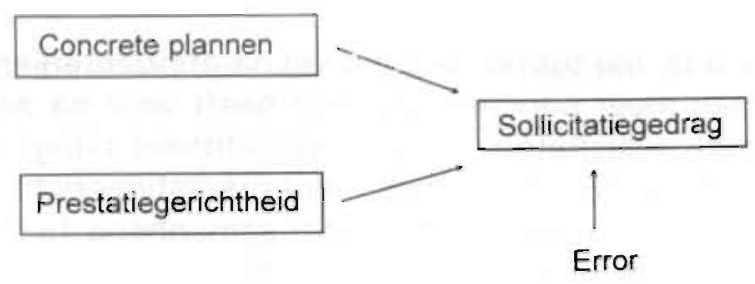

Figuur 5: Causaa! model, voorbeeld 1

Uiteraard was een alternatief model geweest dat beide een onafhankelijke invloed op sollicitatiegedrag uitoefenen; zie figuur 6 .

De daarbij behorende vergelijking is deze:

Sollicitatiegedrag $=$ Concrete plannen + Prestatiegerichtheid + Error

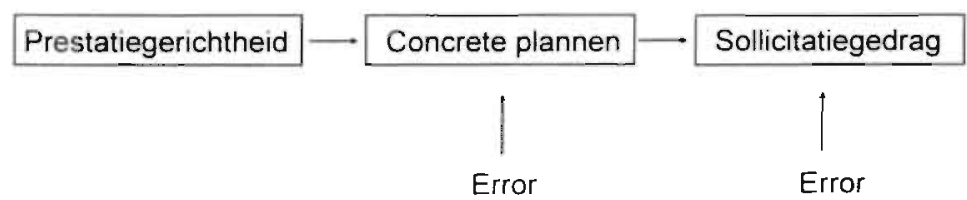

Figuur 6: Causaal model, voorbeeld 2

Het zal duidelijk zijn dat in een dergelijke modellering meer variabelen betrokken kunnen worden. SEM helpt de onderzoeker te beslissen of zijn theoretische model niet door de data wordt tegengesproken. Dat gebeurt, eenvoudig gezegd, door vergelijking van de data met het gepostuleerde model. Dat model kan dan passen of niet passen. Voor de mate van fit wordt de Chi-kwadraat maat gebruikt. Als de bijbehorende statistische test niet significant verschilt van nul, past het model op de data. Er zijn overigens ook andere maten voor fit ontwikkeld, waarvan sommige eigenschappen hebben die te prefereren zijn boven de Chi-kwadraat maat. In deze studie wordt, naast Chi-kwadraat, de $\mathrm{CFI}$, de Comparative Fit Index gerapporteerd. Deze index kan variëren tussen 0 en $1 ; 1$ duidt op een optimale fit.

\section{methode}

De data werden geanalyseerd met behulp van EQS (Bentler, 1995). Omdat duidelijke theoretische restricties aan het onderhavige onderzoek ten grondslag liggen, werden verschillende, even plausibele, varianten getest. SEM is 
in dit onderzoek dan ook gebruikt op een exploratieve wijze. Aan de uit komsten mag derhalve slechts beperkte betekenis gehecht worden.

\section{resultaten}

In figuur 7 zijn de resultaten van de analyses op grafische wijze weergegeven. Het gepresenteerde model past goed; Chi-kwadraat $=7.88, \mathrm{df}=4, \mathrm{p}=.10$; $\mathrm{CFI}=.98$.

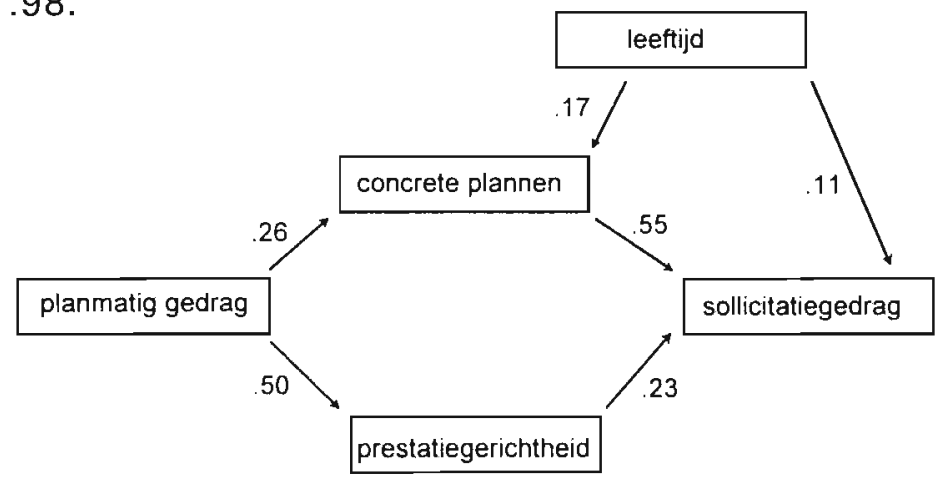

chi-kwadraat $=7.88$, d.f. $=4, p=0.10$

CFI $=0.98$

Figuur 7: De voorbereidingsfase $(n=181)$

In de figuur zijn de errorcomponenten weggelaten. De pijlen in de figuur duiden op de veronderstelde causale invloed; de waarden die de pijlen vergezellen zijn zogenaamde padcoëfficiënten. Zij zijn vergelijkbaar met bètagewichten (of partiële correlaties) en geven de sterkte van de invloed aan. Uit de figuur valt bijvoorbeeld af te leiden dat leeftijd een zwak-positieve invloed ter grootte van .11 uitoefent op sollicitatiegedrag, terwijl de invloed van het maken van concrete plannen aanzienlijk groter is, namelijk .55. Prestatiegerichtheid is eveneens van invloed op sollicitatiegedrag; de waarde van de padcoëfficiënt bedraagt .23. Planmatig gedrag heeft een indirecte invloed op sollicitatiegedrag; namelijk door middel van het effect op de concrete plannen en prestatiegerichtheid. De invloed van planmatig gedrag op prestatiegerichtheid is sterk, te weten .50. De invloed van planmatig gedrag op concrete plannen is kleiner en bedraagt .23 .

\section{Discussie}

In dit hoofdstuk is de voorbereidingsfase beschreven. De fase wordt gekenmerkt door een algemene voorbereiding, die grotendeels impliciet plaatsvindt en die leidt tot het besluit om gericht te gaan solliciteren naar een bepaalde 
functie. Dit gedrag is sollicitatiegedrag genoemd: de geneigdheid om te solliciteren in de laatste fase van de studie.

Uit het verklaringsmodel dat is verkregen door middel van causale modelling blijkt dat slechts enkele van de onderzochte variabelen kunnen worden beschouwd als determinanten van sollicitatiegedrag, namelijk doelgerichtheid, prestatiegerichtheid en leeftijd. De variabelen met betrekking tot kennis van de arbeidsmarkt blijken in het verklaringsmodel geen rol te spelen. Geslacht komt ook niet meer terug in het model, terwijl in de correlatiematrix wel enige verbanden met geslacht waren te zien. Blijkbaar is de mate van doelgerichtheid en prestatiegerichtheid doorslaggevend in de verklaring voor sollicitatiegedrag, ongeacht of dit gedrag door mannen of vrouwen wordt vertoond. Het is opvallend dat er geen relatie is gevonden tussen de variabelen met betrekking tot kennis van de arbeidsmarkt en sollicitatiegedrag. Het hebben van werkervaring en het belang van de stage vertonen geen samenhang met sollicitatiegedrag. Het blijkt dat de werkervaring die is opgedaan door de studenten, voornamelijk is verkregen door middel van student-assistentschappen binnen de universiteit. Mogelijk voegt deze ervaring weinig toe aan de kennis die studenten al hadden van de universteit als organisatie. Nieuwenhuysen en Wielers (1990) beschouwen de ervaring die studenten hebben opgedaan met werk en bestuursfuncties tijdens hun studie als kwaliteitskenmerk van afgestudeerden die de arbeidsmarktpositie verbetert. Mogelijk is er sprake van een indirecte relatie met sollicitatiegedrag, namelijk via de concrete plannen die men heeft voor na de studie. Degenen die werkervaring hebben opgedaan zijn immers vaker van plan te gaan werken in een betaalde baan. Door de werkervaring heeft men waarschijnlijk een concreter beeld gekregen van eigen sterke en zwakke kanten, waardoor men beter in staat zal zijn concrete invulling te geven aan de plannen na de studie. Een dergelijke vertaalslag van ervaringen en kwaliteiten naar interesses en toekomstplannen maakt vaak onderdeel uit van trainingen loopbaanplanning en solliciteren (Van Domburg et al., 1989; Schreurs \& Hommes, 1992; Van Ettinger \& Van Asperen, 1991).

De meest duidelijke relatie is gevonden tussen doelgerichtheid en sollicitatiegedrag. Concrete plannen na afstuderen en planmatig gedrag zijn beide indicatoren van doelgerichtheid. Een concreet beeld van de situatie na afloop van de studie maakt het mogelijk activiteiten te plannen om dat doel te bereiken. Bowditch en Buono (1990) beschrijven in de goal-setting theorie dat bewuste doelen de belangrijkste determinanten zijn van taakgerichte gedragingen. Specifieke doelstellingen leiden tot meer gerichte inspanningen dan algemene doelstellingen. Het beschikken over planmatig gedrag is een voorwaarde om een doel te kunnen stellen en de weg uit te stippelen die leidt naar het gewenste doel. Planmatig gedrag blijkt indirect van invloed te zijn in het verklaringsmodel. Opvallend is dat de vrouwen in de onderzoeksgroep meer planmatig zijn dan de mannen. In het verklaringsmodel komt geslacht als variabele niet meer naar voren. Deze bevindingen vertonen overeenkomsten met die van Larwood en Gattiker (1987) in hun onderzoek naar determinanten van succes 
volle loopbanen van mannen en vrouwen. Gedurende langere tijd gericht toewerken naar een gesteld doel bleek hierbij eveneens belangrijk.

$V$ an de persoonlijkheidsaspecten blijkt met name prestatiegerichtheid relevant. lemand die in hoge mate prestatiegericht is, zal eerder geneigd zijn te gaan solliciteren als het afstuderen in zicht komt. De behoefte om hoog te presteren leidt er blijkbaar toe dat men na afstuderen zo snel mogelijk aan de slag wil in een betaalde baan. Volgens het verklaringsmodel blijkt planmatig gedrag hierop eveneens van invloed te zijn. Dit is merkwaardig omdat prestatiegerichtheid door Hermans (1976) min of meer wordt beschouwd als een dispositie. Planmatig gedrag en prestatiegerichtheid kunnen waarschijnlijk als representanten van dezelfde persoonlijkheidsdimensie beschouwd worden. Van Dam (1995) geeft hiervoor enige aanwijzingen in haar onderzoek naar de big five, als basis voor een vijffactorenmodel voor personeelsselectie. De dimensie 'zorgvuldigheid' wordt door sommige onderzoekers 'will to achieve' en 'work' genoemd. Op deze dimensie laden trekken als zorgvuldig, stipt en ijverig enerzijds, en gemakzuchtig, nonchalant en ongevoelig anderzijds.

Ook op het onderdeel prestatiegerichtheid scoren vrouwen hoger. De mannelijke respondenten zijn in mindere mate prestatiegericht. In het verklaringsmodel vinden we dit verschil niet meer terug.

Leeftijd en sollicitatiegedrag hangen eveneens met elkaar samen, hoewel de directe relatie zwak is. Degenen die ouder zijn, zijn eerder geneigd om te gaan solliciteren tegen de tijd dat ze afstuderen. Indirect is er een relatie met de concrete plannen na de studie. De vrouwelijke respondenten zijn gemiddeld jonger dan de mannen.

Mannen en vrouwen bleken eveneens te verschillen op de variabele selfefficacy. Mannen gaan er vaker vanuit dat zij in staat zijn de gewenste baan te realiseren. Vrouwen zijn hierover vaker twijfelachtig.

Bij de meeste variabelen uit het verklaringsmodel vonden we in de correlatiematrix een verschil tussen mannen en vrouwen, terwijl de variabele geslacht in het model niet terug komt. Hoe moeten we dit interpreteren? Vrouwen scoorden hoger op planmatig gedrag en prestatiegerichtheid. Op basis hiervan zouden we mogen verwachten dat het sollicitatiegedrag eveneens hoger zou zijn, terwijl dit niet het geval is. Waarschijnlijk ligt de verklaring in het feit dat de vrouwen jonger zijn en dat dit verwachte positieve effect door de variabele leeftijd wordt genivelleerd. 



\section{5}

\section{Verwerven van een baan}

De tweede fase in het overgangsproces van de opleiding naar de arbeidsmarkt heeft betrekking op het verwerven van een baan na het afstuderen. Na een algemene voorbereiding en arbeidsmarktoriëntatie gaan de meeste studenten gericht op zoek naar een baan. Wanneer een betaalde baan is verkregen, is deze fase afgerond. Het solliciteren naar een baan vereist dat de student of afgestudeerde een duidelijk beeld heeft van de gewenste functie en van de organisatie waarin hij of zij wil werken. Meestal heeft men een duidelijk idee over de omvang van het dienstverband: een full-time dienstverband of een functie in deeltijd. De voorkeur voor een bepaald werkterrein kan al aanwezig zijn sinds de start met de opleiding. De opleiding is dan gekozen vanuit arbeidsmarktperspectieven. Volgens Nieuwenhuysen en Wielers (1990) is een arbeidsmarktgerichte houding van invloed op het vinden van een baan. Een meer afwachtende en defensieve houding is niet bevorderlijk voor het veroveren van een plaats op de arbeidsmarkt. De motieven die men nastreeft in een loopbaan kunnen eveneens relevant zijn. Loopbaanankers (Schein, 1978; Derr, 1986) zijn betrekkelijk constante drijfveren in de werksituatie. Het nastreven van een hogere functie en de gerichtheid op ontplooiing hangen mogelijk samen met het vinden van een baan.

Een baan wordt verkregen door te solliciteren. Het toepassen van bepaalde vaardigheden draagt bij aan succesvol solliciteren. De student moet een goede sollicitatiebrief kunnen schrijven waarin blijk wordt gegeven van inzicht in de vacature en in de organisatie. In de brief en in het gesprek zal men aannemelijk moeten maken dat men over relevante kwaliteiten beschikt. Om dit goed te kunnen overbrengen maakt men gebruik van sociale vaardigheden en leidinggevende kwaliteiten. Sociale vaardigheden zijn met name van belang voor het tactvol en op positieve wijze verwoorden van de overeenkomsten tussen datgene wat men te bieden heeft en de functie-eisen. In staat zijn om initiatieven te nemen en de situatie naar de hand te zetten lijken eveneens van belang. Vander Meeren (1993) geeft aan dat communicatieve vaardigheden van belang zijn in het selectieproces.

Wat betreft de relevante persoonlijkheidskenmerken voor het verkrijgen van een baan denken we in de eerste plaats aan een hoge zelfwaardering. Wanneer iemand een positief beeld heeft van zichzelf kan dit een rol spelen in de sollicitatieprocedure. Verder zal de overtuiging een rol spelen dat men in staat 
is te realiseren waar de voorkeur naar uit gaat. Self-efficacy ten aanzien van het verwerven van een baan is kortom van belang.

Mogelijk is er een verschil tussen mannen en vrouwen in deze fase van het overgangsproces van de opleiding naar de arbeidsmarkt. De persoonlijkheid van de kandidaat geeft uiteindelijk vaak de doorslag in het selectieproces (Van Vianen, 1987).

Hierna staat beschreven hoe deze variabelen zijn geoperationaliseerd. Na de beschrijving van de variabelen volgt een schema met de statistische kenmerken van de variabelen. De gemiddelde waarde, standaarddeviatie, de minimum- en maximumwaarde die de variabelen aannemen en het aantal respondenten bij de betreffende variabele. Tevens is aangegeven uit welke meting de variabelen afkomstig zijn.

\section{Variabelen uit de fase van baan verwerven}

1. Baan. Deze variabele meet het al dan niet hebben van een betaalde functie. De variabele is dichotoom en kan de waarde 1 en 2 aannemen.

2. Studiekeuze. Deze variabele geeft de motieven voor studiekeuze aan. Sommigen hebben al duidelijke beroepsperspectieven bij aanvang van de studie. Anderen kiezen een studie puur op basis van interesse. Een arbeidsmarktgerichte studiekeuze zou kunnen samenhangen met het sneller vinden van een baan. De waarden die de variabele kan aannemen loopt van 1 keuze uits/uitend op basis van interesse tot 5 keuze uits/uitend op basis van arbeidsmarktperspectief.

3. Omvang dienstverband. Deze variabele betreft de gewenste omvang van de werkweek. Hoeveel uur per week wil men werken in een betaalde baan? De waarde varieert van 1 tot $5 ; 1$ staat voor een zeer beperkt dienstverband tot 8 uur per week; 5 betekent een fulltime baan.

4. Gerichtheid op een hogere functie. Deze variabele vormt een indicatie voor een bepaalde carrière-oriëntatie. Personen die hoog scoren op deze variabele zijn gericht op een verantwoordelijke positie en een hoog inkomen. Het gaat om drie items uit een lijst van aspecten die van belang zijn voor de toekomstige werksituatie. De betrouwbaarheid van de subschaal is acceptabel; Cronbach's alpha $=.54$. De waarde varieert tussen 1 en 3.

5. Gerichtheid op ontplooiing. Deze variabele geeft wederom een bepaalde carrière-oriëntatie aan. Personen die hoog scoren op deze variabele zijn gericht op ontwikkeling van eigen capaciteiten. Het gaat om drie items uit een lijst van aspecten die van belang zijn voor de toekomstige werksituatie. De betrouwbaarheid van de subschaal is acceptabel; Cronbach's alpha $=.62$. De waarde varieert van 1 tot 3 .

6. Sociale vaardigheden. Deze variabele is gemeten met behulp van een subschaal Sociale Inadekwatie van de Nederlandse persoonlijkheidsvragenlijst. Personen die hoog scoren op deze schaal voelen zich ongemakkelijk in sociale situaties. Laagscoorders zijn in staat adequaat te reageren in sociale situaties. 
7. Leidinggevende vaardigheden. Deze variabele omvat een aantal vaardigheden, zoals voorzitten, verantwoordelijkheid nemen in een groep en een helicoptervisie hebben over de situatie. Het betreft een schaal van 7 items uit de vragenlijst Persoonlijke Kwaliteiten en PGO. De betrouwbaarheid van de schaal is redelijk, Cronbach's alpha $=.67$. De waarde varieert van 1 tot 5 . 8. Zelfwaardering. Zelfwaardering is gemeten met een subschaal van de Nederlandse persoonlijkheidsvragenlijst. De waarde van de variabele zelfwaardering is de somscore op deze schaal. Items uit de schaal verwijzen naar een positieve instelling ten opzichte van werken, veranderbaar en goed aangepast zijn.

9. Self-efficacy. Deze variabele geeft aan of men verwacht de gewenste baan te krijgen. Het blijkt dat degenen die verwachten een bepaalde taak goed te volbrengen, vaker in staat zijn dit daadwerkelijk te realiseren. De waarde die de variabele kan aannemen loopt van 1 tot 3 .

10. Geslacht. Mogelijk zijn er verschillen tussen mannen en vrouwen bij het verwerven van een baan.

Tabel 5.1: Statistische kenmerken van de variabelen van de fase baan verwerven

\begin{tabular}{lcccccc}
\hline \multicolumn{1}{c}{ variabele } & gem. & s.d. & $\min$. & $\max$. & $\mathrm{n}$ & meting \\
\hline 1. baan & - & - & & & & \\
2. studiekeuze & 1.80 & 1.28 & 1 & 5 & 216 & 1 \\
3. omvang dienstverband & 4.44 & .65 & 2 & 5 & 207 & 1 \\
4. hogerop & 1.88 & .52 & 1 & 3 & 218 & 1 \\
5. ontplooiing & 2.49 & .56 & 1 & 3 & 221 & 1 \\
6. sociale vaardigheden & 5.78 & 5.56 & 0 & 26 & 166 & 2 \\
7. leidinggeven & 3.83 & .40 & 2.71 & 4.71 & 177 & 2 \\
8. zelfwaardering & 29.64 & 4.92 & 13 & 38 & 166 & 2 \\
9. self-efficacy & 1.95 & .96 & 1 & 3 & 218 & 1 \\
10. geslacht & - & - & 1 & 2 & 223 & 1 \\
& & & & & & \\
\hline
\end{tabular}

\section{Kenmerken van de fase van baan verwerven}

In deze paragraaf wordt beschreven hoe de respondenten te typeren zijn op de verschillende variabelen.

Allereerst wordt gekeken naar de afhankelijke variabele het hebben van een baan. Hoeveel respondenten hebben een baan gevonden in de periode van éen jaar na afname van de loopbaanenquête? In de volgende tabel staan de resultaten weergegeven.

Ruim de helft van de studenten in het onderzoek heeft op dat moment geen baan, iets minder dan de helft heeft een betaalde functie. Er lijkt een tendens 
die gunstiger is voor de mannen. Van de mannen heeft ruim de helft een baan. Van de vrouwen heeft meer dan de helft nog geen baan, namelijk $59 \%$. Dit verschil is echter niet significant.

Tabel 5.2: Baan $(n=178)$

\begin{tabular}{llrr}
\hline & & & \\
& mannen & vrouwen & totaal \\
\cline { 2 - 3 } & $21(48 \%)$ & $79(59 \%)$ & $100(56 \%)$ \\
1. heeft geen baan & $23(52 \%)$ & $55(41 \%)$ & $78(44 \%)$ \\
$\chi^{a}=1.70, \mathrm{df}=1$, n.s. & & \\
\hline
\end{tabular}

\section{arbeidsmarktgerichtheid}

Hoe meer men gericht is op de arbeidsmarkt des te sneller zal men ook een baan vinden. In welke mate speelt arbeidsmarktgerichtheid een rol bij studenten? Gevraagd is naar de motieven voor studiekeuze. De motivatie kan met name liggen op het inhoudelijke vlak of gericht zijn op de arbeidsmarktperspectieven van de opleiding. We beschouwen de omvang van het gewenste dienstverband als een indicator van arbeidsmarktgerichtheid. Hoe meer uren men wil werken des te sterker is de betrokkenheid bij de arbeidsmarkt. Verschillende vormen van arbeidsmarktoriëntatie worden ook beschouwd als arbeidsmarktgerichtheid. De behoefte om een hogere functie te bereiken en de behoefte aan zelfontplooiing in een baan zijn indicatoren van arbeidsmarktgerichtheid.

In de volgende tabel is een verdeling opgenomen van de motieven voor studiekeuze, uitgesplitst naar mannelijke en vrouwelijke studenten. De motieven kunnen variëren van een keuze puur op basis van interesse tot een keuze voornamelijk op basis van de perspectieven op de arbeidsmarkt. De afstand tussen de verschillende alternatieven wordt als gelijk beschouwd.

Opvallend is het hoge aantal studenten dat uitsluitend kiest op basis van interesse. Slechts $5 \%$ van de respondenten heeft gekozen voor de studie op basis van arbeidsmarktperspectieven. Ook de combinatie van interesse en mogelijkheden op de arbeidsmarkt komt in beperkte mate voor. Er zijn nauwelijks verschillen tussen de motieven voor studiekeuze van mannelijke en vrouwelijke studenten. Vrouwen kiezen iets vaker op basis van interesse en voor mannen is de studie vaker een vervolg op eerdere opleiding of werkervaring. De verschillen zijn echter heel klein. 


\begin{tabular}{lrrr}
\hline & mannen & vrouwen & totaal \\
\cline { 2 - 4 } & $35(66 \%)$ & $112(69 \%)$ & $147(68 \%)$ \\
interesse & $4(8 \%)$ & $7(4 \%)$ & $11(5 \%)$ \\
tweede keuze & $7(13 \%)$ & $15(9 \%)$ & $22(10 \%)$ \\
aansluiting op opleiding/werk & $5(9 \%)$ & $21(13 \%)$ & $26(12 \%)$ \\
comb. interesse/arbeidsmarkt & $2(4 \%)$ & $8(5 \%)$ & $10(5 \%)$ \\
arbeidsmarkt & & & \\
$x^{2}=2.01, \mathrm{df}=4$, n.s. & & & \\
\hline
\end{tabular}

Twee vormen van arbeidsmarktoriëntatie zijn onderzocht, namelijk gerichtheid op een hogere functie en gerichtheid op zelfontplooiing. Personen die gericht zijn op ontplooiing vinden de ontwikkeling van eigen capaciteiten belangrijk. Personen die gericht zijn op een hogere functie willen graag een verantwoordelijke positie en een hoog inkomen.

Tabel 5.4: Gerichtheid op ontplooiing $(n=221)$ en gerichtheid op hogere functie $(n=118)$

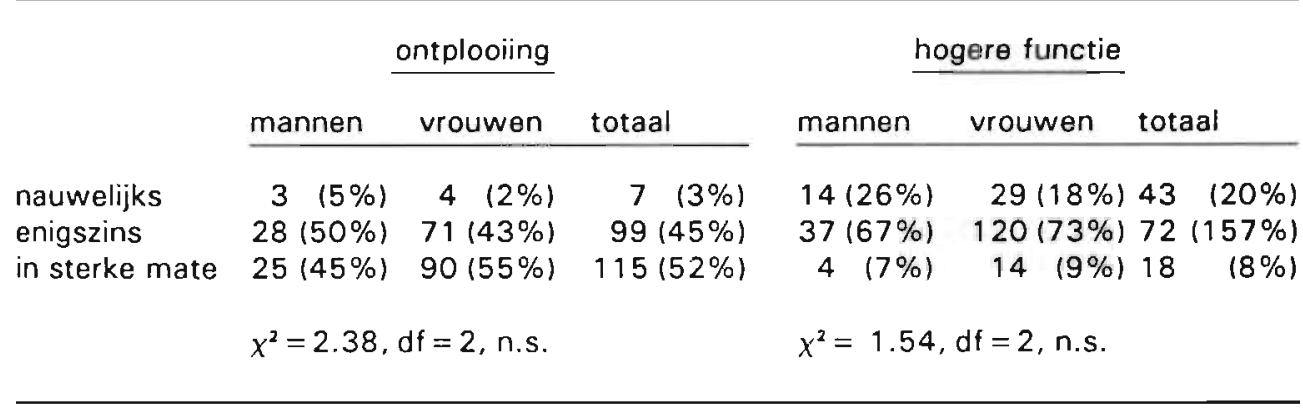

Meer dan de helft van de studenten blijkt zelfontplooiing erg belangrijk te vinden in hun toekomstige werksituatie, namelijk $52 \%$. Er lijkt een tendens dat vrouwen dit aspect belangrijker vinden dan mannen. Van de vrouwen vindt $55 \%$ ontplooiing erg belangrijk, tegen $45 \%$ van de mannen. lets minder dan de helft van de studenten (namelijk $45 \%$ ) vindt dit aspect wenselijk in de toekomstige werksituatie.

Slechts $8 \%$ van de respondenten vindt een hogere functie erg belangrijk. Het merendeel van de studenten, namelijk $72 \%$, geeft aan dit wenselijk te vinden. Eenvijfde van de studenten vindt dit aspect onbelangrijk. Opvallend is dat in verhouding meer mannen dan vrouwen ( $26 \%$ versus $18 \%$ ) een hogere functie onbelangrijk vinden. 
In de volgende tabel is weergegeven hoeveel uur per week men het liefst wil werken in een betaalde baan.

Ruim de helft van de studenten wil een full-time baan. Ruim eenderde wil vier dagen per week werken. Een klein deel $(7 \%)$ wil drie dagen of minder werken. Het grootste deel van de mannen, namelijk tweederde, prefereert een full-time baan, tegen iets minder dan de helft van de vrouwelijke studenten. Een aanzienlijk deel van de vrouwen geeft de voorkeur aan een vierdaagse werkweek. De verschillen tussen de voorkeur van mannen en van vrouwen zijn marginaal significant.

Tabel 5.5: Voorkeur ornvang dienstverband $(n=207)$

\begin{tabular}{lrrr} 
& mannen & vrouwen & \multicolumn{1}{c}{ totaal } \\
\cline { 2 - 4 }$\leq 24$ uur & $5(9 \%)$ & $14(9 \%)$ & $19(7 \%)$ \\
$25-32$ & $14(26 \%)$ & $65(43 \%)$ & $79(38 \%)$ \\
$33-40$ & $36(66 \%)$ & $73(48 \%)$ & $109(53 \%)$ \\
$x^{2}=5.50, d f=2, p=.06$ & & & \\
\hline
\end{tabular}

Samenvattend kunnen we stellen ten aanzien van de arbeidsmarktgerichtheid van studenten dat relatief weinig studenten kiezen voor de studie gezondheidswetenschappen vanwege de arbeidsmarktperspectieven van de studie. Men is goed in staat aan te geven naar welke functie de voorkeur uitgaat. Ook ten aanzien van de gewenste arbeidsvoorwaarden heeft men een duidelijk beeld. In de toekomstige functie streeft de helft van de studenten zelfontplooiing na. Het verkrijgen van een hogere functie vindt het merendeel van de studenten wenselijk.

\section{sollicitatievaardigheden}

Om een baan te verkrijgen zal men moeten solliciteren. Of men reageert op een advertentie, een open sollicitatiebrief schrijft of via netwerken contacten probeert te leggen, op een gegeven moment spelen sociale vaardigheden een belangrijke rol. Een goede communicatiestijl in sociale situaties is in vrijwel elke functie van belang. Dit geldt ook voor de sollicitatiesituatie. In een gesprek met een potentiële werkgever of toekomstige chef moet men duidelijk kunnen maken wat men aan kennis en vaardigheden heeft te bieden. Leidinggevende kwaliteiten zijn eveneens van belang. Om een baan te verwerven zal men initiatieven moeten nemen.

Sociale vaardigheden zijn gemeten met behulp van een subschaal van de $\mathrm{Ne}$ derlandse Persoonlijkheidsvragenlijst. Het gaat om de sociale inadekwatieschaal. Een lage score op de schaal verwijst naar goede sociale vaardigheden. 
De scores zijn vergeleken met normgroepen. De verdeling is weergegeven in de volgende tabel.

Opvallend is de concentratie bij de hoogste categorieën. Meer dan driekwart van de respondenten is boven gemiddeld tot zeer hoog sociaal vaardig. Slechts $8 \%$ van de respondenten scoort beneden gemiddeld tot zeer laag. De gemiddelde score bedraagt 5.78. De mannen scoren gemiddeld 5.88 (s.d. 5.45 ), de gemiddelde score van vrouwen bedraagt 5.74 (s.d. 5.62). Voor de normgroep is het gemiddelde bij de mannen 9.5 en bij de vrouwen gemiddeld 12.3. Wellicht ten overvloede: de lage score duidt op een hogere sociale vaardigheid.

Tabel 5.6: Sociale vaardigheden $(n=165)$

\begin{tabular}{lrc}
\hline & aantal & percentage \\
\cline { 2 - 3 } & 42 & 25 \\
1. zeer hoog & 54 & 33 \\
2. hoog & 32 & 20 \\
3. boven gemiddeld & 23 & 14 \\
4. gemiddeld & 8 & 4 \\
5. beneden gemiddeld & 5 & 3 \\
6. laag & 1 & 1 \\
7. zeer laag & & \\
\hline
\end{tabular}

Leidinggeven is gemeten met een subschaal van de vragenlijst Persoonlijke kwaliteiten en PGO. Van de scores op de schaal zijn categorieën gevormd.

Tabel 5.7: Leidinggevende kwaliteiten $(n=177)$

\begin{tabular}{lrrr}
\hline & mannen & vrouwen & \multicolumn{1}{c}{ totalal } \\
\cline { 2 - 4 } & $2(4 \%)$ & $3(2 \%)$ & $5(3 \%)$ \\
1. enigszins & $31(69 \%)$ & $94(71 \%)$ & $125(70 \%)$ \\
2. in redelijke mate & $12(27 \%)$ & $35(27 \%)$ & $47(27 \%)$ \\
3. in hoge mate & & & \\
$x^{2}=.59, \mathrm{df}=2$, n.s. & & & \\
\hline
\end{tabular}

Studenten geven aan dat zij in redelijke mate beschikken over leidinggevende kwaliteiten. Ruim eenvierde vindt zichzelf in hoge mate in staat leiding te geven aan een taakgerichte groep. Niemand geeft aan in beperkte mate te beschikken over dergelijke kwaliteiten en slechts een enkeling is van mening enigszins in staat te zijn de leiding op zich te nemen. 
Samenvattend: de groep respondenten geeft aan in hoge mate sociaal vaardig te zijn, en vrijwel iedereen zegt te beschikken over leidinggevende kwaliteiten.

\section{persoonlijkheidsaspecten}

Relevante persoonlijkheidsaspecten in deze fase zijn zelfwaardering en selfefficacy. Self-efficacy is in het vorige hoofdstuk besproken (zie tabel 4.7). Zelfwaardering is van belang bij de persoonlijke presentatie in de sollicitatiebrief en in het sollicitatiegesprek. Bovendien is zelfwaardering van belang bij het omgaan met tegenslagen bij sollicitaties. De relevantie van self-efficacy is reeds genoemd in het hoofdstuk over de voorbereidende fase. In de volgende tabel wordt een verdeling gegeven van de score op de schaal voor zelfwaardering. De scores zijn vergeleken met een normgroep.

Tabel 5.8: Zelfwaardering $(n=165)$

\begin{tabular}{lrr}
\hline & aantal & percentage \\
\cline { 2 - 3 } & 3 & 2 \\
1. zeer laag & 19 & 11 \\
2. laag & 2 & 2 \\
3. beneden gemiddeld & 75 & 45 \\
4. gemiddeld & 16 & 10 \\
5. boven gemiddeld & 33 & 20 \\
6. hoog & 17 & 10 \\
7. zeer hoog & \\
\end{tabular}

Bijna de helft van de respondenten ( $45 \%)$ scoort gemiddeld op deze schaal. Veertig procent heeft een boven gemiddelde tot zeer hoge zelfwaardering. Een kleine groep van $15 \%$ heeft een beneden gemiddelde zelfwaardering. De gemiddelde waarde bedraagt 29.64. Dit is hoger dan de normgroep waarbij het gemiddelde 28.00 bedraagt. Er is nauwelijks verschil tussen mannen en vrouwen: de gemiddelde score van de mannen bedraagt 29.51 (s.d. 4.25) en de vrouwen scoren gemiddeld 29.69 (s.d. 5.14).

\section{persoonlijke situatie}

Gekeken is naar het verschil tussen mannen en vrouwen in deze fase van baanverwerven. In tabel 5.2 is aangegeven hoe de verhouding is tussen mannen en vrouwen met en zonder baan. $E r$ is een tendens dat mannen vaker een baan hebben dan vrouwen. Van de mannen heeft ruim de helft een baan $(52 \%)$; van de vrouwen heeft slechts $41 \%$ een baan. 


\section{Relaties tussen arbeidsmarktgerichtheid, sollicitatievaardighe- den, persoonlijkheidsaspecten en het hebben van een baan}

In de vorige paragraaf zijn de kenmerken van de fase van baan verwerven besproken. Aangegeven werd in welke mate arbeidsmarktgerichtheid, sollicitatievaardigheden en persoonlijkheidsaspecten een rol spelen in deze fase van het overgangsproces van de opleiding naar de arbeidsmarkt.

Hieronder wordt ingegaan op de relaties tussen de onafhankelijke variabelen en het hebben van een baan na afstuderen. Allereerst wordt de correlatiematrix weergegeven van de onafhankelijke variabelen. Daarna worden de correlaties met het hebben van een baan gepresenteerd. De correlaties tussen de afhankelijke variabelen en het hebben van een baan worden in een aparte tabel gepresenteerd, omdat hierdoor duidelijk zichtbaar wordt welke variabelen in deze fase van belang zijn.

Tabel 5.9: Correlatiematrix van de fase van baanverwerven $(153 \leq n \leq 180)^{2}$

\begin{tabular}{|c|c|c|c|c|c|c|c|c|c|}
\hline & 1 & 2 & 3 & 4 & 5 & 6 & 7 & 8 & 9 \\
\hline 1. studiekeuze & 1.00 & $.15^{\circ}$ & .11 & .08 & $.17^{\circ}$ & .08 & .04 & $.18^{\circ}$ & .00 \\
\hline 2. omv. dienstverband & & 1.00 & $.26^{\cdots}$ & .12 & .09 & .03 & .04 & .03 & -.13 \\
\hline 3. hogere functie & & & 1.00 & $.21^{\circ}$ & $.19^{\circ}$ & .11 & .12 & $.22^{\circ}$ & .00 \\
\hline 4. ontplooiing & & & & 1.00 & $.21^{*}$ & $.26^{\cdots}$ & $.17^{\circ}$ & .06 & .07 \\
\hline 5. sociale vaardigh. & & & & & 1.00 & $31^{\cdots}$ & $.43^{\cdots}$ & .14 & .01 \\
\hline 6. leidinggeven & & & & & & 1.00 & $.34^{\cdots}$ & $.28^{\cdots}$ & .02 \\
\hline 7. zelfwaardering & & & & & & & 1.00 & $.20^{\circ}$ & .02 \\
\hline 8. self-efficacy & & & & & & & & 1.00 & -.14 \\
\hline 9. geslacht & & & & & & & & & 1.00 \\
\hline $1^{*} p \leq .05,{ }^{*} p \leq .01$. & $* * *$ & $\leq .001)$ & & & & & & & \\
\hline
\end{tabular}

Het blijkt dat de motieven voor studiekeuze samenhangen met de omvang van het dienstverband, met sociale vaardigheden en met self-efficacy. Dit betekent dat er een verband is tussen een meer arbeidsmarktgerichte studiekeuze en het aantal uren dat men per week wil werken. Een meer arbeidsmarktgerichte studiekeuze houdt ook verband met een hogere sociale vaardigheid. Verder blijken degenen die hun studie hebben gekozen vanuit arbeidsmarktperspectieven sterker van mening te zijn dat zij de gewenste baan zullen verwezenlijken.

\footnotetext{
${ }^{2}$ De exacte waarde van $n$ per cel van de correlatiematrix staat vermeld in tabel 2 in de bijlage.
} 
De gewenste omvang van het dienstverband houdt verband met het streven naar een hogere functie. Naarmate men meer uren per week wil werken vindt men het belangrijker een hogere functie te krijgen. Het nastreven van een hogere functie houdt eveneens verband met het streven naar zelfontplooiing, met sociale vaardigheden en met self-efficacy. Dit betekent dat naarmate men meer gericht is op een hogere functie men ook meer gericht is op zelfontplooiing. En naarmate men meer gericht is op een hogere functie is men meer sociaal vaardig, en verwacht men sterker dat men de gewenste baan kan realiseren. Gerichtheid op ontplooiing hangt ook samen met sociale vaardigheden en eveneens met leidinggevende kwaliteiten en met zelfwaardering.

De variabele sociale vaardigheden hangt samen met leidinggevende kwaliteiten en met zelfwaardering. Naarmate men meer sociaal vaardig is, geeft men aan in hogere mate te beschikken over leidinggevende kwaliteiten en is de zelfwaardering ook hoger. De variabele leidinggevende kwaliteiten hangt samen met zelfwaardering en self-efficacy. Naarmate men aangeeft meer over leidinggevende kwaliteiten te beschikken, denkt men ook vaker de baan te kunnen verwezenlijken die men voor ogen heeft. Zelfwaardering blijkt ook samen te hangen met self-efficacy. Naarmate de zelfwaardering hoger is verwacht men des te sterker de gewenste baan te kunnen realiseren.

Geslacht vertoont geen relaties met andere onafhankelijke variabelen in deze fase, hoewel bij twee variabelen een bepaalde tendens te zien is namelijk de omvang van het dienstverband en self-efficacy. Vrouwen willen minder uren werken en zij zijn onzekerder over het bereiken van de gewenste baan. Deze verschillen zijn echter niet significant. Blijkbaar verschillen mannen en vrouwen niet op de variabelen in de fase van baanverwerven.

In de tabel 5.10 staan de correlaties met het hebben van een baan weergegeven. Uit de tabel blijkt dat vrijwel alle variabelen samenhangen met het hebben van een baan. Alleen voor de variabele geslacht is dit niet het geval. $\mathrm{Er}$ is geen significant verschil gevonden in het percentage mannen en vrouwen dat kort na afstuderen een baan heeft verworven. De meest sterke relatie is gevonden tussen de gewenste omvang van de werkweek en het dienstverband. Degenen die een full-time baan wilden, blijken er vaker in te slagen een baan te vinden dan degenen die in deeltijd willen werken.

De variabelen die betrekking hebben op arbeidsmarktgerichtheid vertonen alle samenhang met het hebben van een baan, met name de gewenste omvang van de werkweek. Ook de gerichtheid op een hogere functie, de gerichtheid op zelfontplooiing en de motieven voor studiekeuze hangen samen met het hebben van een baan. De variabelen op het gebied van sollicitatievaardigheden vertonen eveneens samenhang met het hebben van een baan. Het gaat hierbij om sociale vaardigheden en leidinggeven.

Er blijkt eveneens een verband tussen zelfwaardering en self-efficacy met het hebben van een baan. 
1. studiekeuze

2. omv. dienstverband

3. hogere functie

4. ontploaiing

5. sociale vaardigh.

6. leidinggeven

7. zelfwaardering

8. self-efficacy

9. geslacht

\section{$.14^{*}$}

$28 * *$

$.18^{*}$

$.16^{*}$

$.18^{*}$

$.18^{*}$

$.18^{*}$

$.19^{* *}$

$-.09$

$(* p \leq .05, * * p \leq .01, * * p \leq .001)$

\section{Causale modellering van de fase van het verwerven van een baan}

De gevonden verbanden tussen variabelen in de fase van het verwerven van een baan, hebben we eveneens onderworpen aan SEM, (het modelleren van structurele vergelijkingen) (Bentler, 1995). Voor een korte uitleg van de aard van de betreffende techniek zij verwezen naar hoofdstuk 4, paragraaf 4 . Hier wordt volstaan met de constatering dat deze analyses vooral als exploratief moeten worden geduid.

methode

De data werden geanalyseerd met behulp van EOS (Bentler, 1995).

\section{resultaten}

In figuur 8 zijn de resultaten van de analyses op grafische wijze weergegeven. Het gepresenteerde model past goed: Chi-kwadraat $=7,83, \mathrm{df}=8, \mathrm{p}=$ $0.45 ; \mathrm{CFI}=1.00$. 


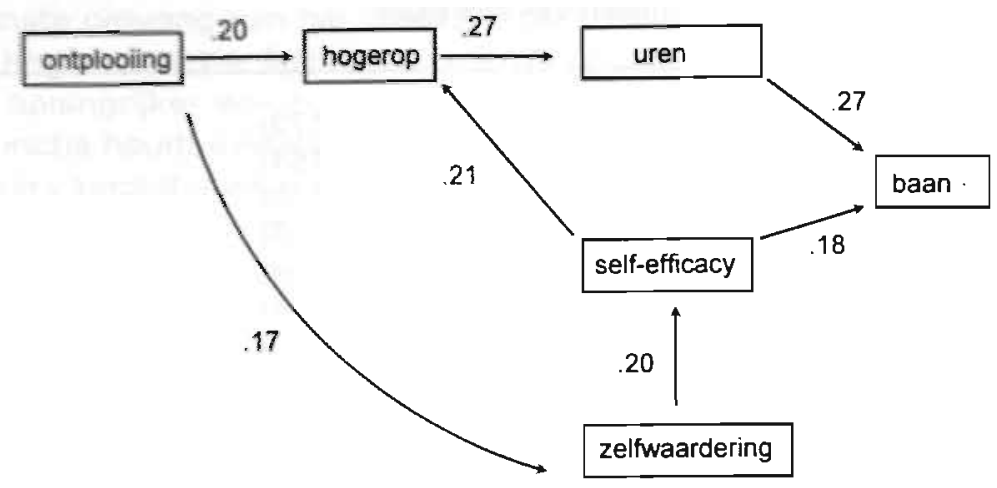

chi-kwadraat $=7.83$, d.f. $=8, p=0.45$

$\mathrm{CFI}=1.00$

Figuur 8 : de fase van baan verwerven $(n=181)$

Uit de figuur valt af te leiden dat de hoeveelheid uren die men wil werken direct van invloed is op het hebben van een baan; de waarde van de padcoëfficiënt bedraagt .27. Self-efficacy is ook direct van invloed op het hebben van een baan .18. Zelfwaardering oefent positief invloed uit op selfefficacy, ter grootte van .20. Hoe hoger de zelfwaardering, des te sterker ook het gevoel van self-efficacy en des te groter de kans dat daadwerkelijk een baan wordt verworven. Self-efficacy is eveneens van invloed op het ambiëren van een hogere functie (.21). De hoeveelheid uren die men wil werken, wordt direct beinvloed door de gerichtheid op een hogere functie, ter grootte van .27. Hogerop willen komen wordt beïnvloed door de gerichtheid op ontplooiing $(.20)$.

\section{Discussie}

In dit hoofdstuk werd de fase van baan verwerven besproken. Deze fase omvat het gericht zoeken naar een baan en resulteert in het hebben van een betaalde functie.

Uit het verklaringsmodel dat is verkregen door causale modellering van de variabelen in deze fase, blijkt dat slechts enkele van de onderzochte variabelen kunnen worden beschouwd als determinanten van het hebben van een baan. Alleen het aantal uren dat men wil werken en self-efficacy zijn direct van invloed op het hebben van een baan. Variabelen met betrekking tot sollicitatievaardigheden blijken in het model geen rol te spelen. Alleen variabelen uit de categorieën arbeidsmarktgerichtheid en persoonlijkheidskenmerken komen in het model terug, waarbij het nastreven van een hogere functie, het na- 
streven van zelfontplooiing en zelfwaardering een indirecte invloed hebben op het verwerven van een baan.

Degenen die tijdens hun studie een voltijdse of bijna voltijdse baan ambieerden, hebben vaker een baan gevonden dan degenen die slechts in deeltijd wilden werken. Dit zou kunnen samenhangen met het aanbod van voltijdse banen op de arbeidsmarkt. Mogelijk zijn er minder deeltijd banen beschikbaar. Toch kan ook een andere verklaring worden gegeven, aangezien er een samenhang is tussen de gerichtheid op een hogere functie en de voorkeur voor een voltijdse baan. Het kan zijn dat hieraan een bepaalde ambitie ten grondslag ligt. De sterke motivatie om een baan te vinden zou dan samengaan met de wens een full-time baan te vinden en hogerop te willen komen in het werk. Sanders (1991) betrekt in haar onderzoek ook de gewenste omvang van het dienstverband. Mannen willen vaker een full-time baan dan vrouwen, maar er zijn ook grote verschillen tussen vrouwen onderling. Een verklaring wordt gegeven door het levensperspectief van betrokkenen; Wat verwacht men tien jaar na het afstuderen te hebben gerealiseerd? Een full-time baan? Een gezin? Mannen verwachten vaak en/en; voor vrouwen is dat vaker of/of. Het levensperspectief blijkt meer van invloed dan het geslacht. Dit hangt mogelijk ook samen met het feit dat geslacht niet in het verklaringsmodel voorkomt.

$\mathrm{Er}$ is ook een directe relatie gevonden tussen self-efficacy en het hebben van een baan. De overtuiging dat de gewenste baan wordt bereikt, heeft een positieve invloed op het realiseren van die wens. Mannen en vrouwen blijken te verschillen in self-efficacy ten aanzien van de gewenste functie. Broekmate en Schreurs (1994) vonden een verschil tussen mannen en vrouwen in de houding ten aanzien van solliciteren. Bij onderzoek naar de effecten van een training solliciteren gaven vrouwelijke studenten aan in sterkere mate op te zien tegen het solliciteren dan hun mannelijke collega's. Het verwerven van een baan werd door hen als moeilijk gepercipieerd. De mannen die deelnamen aan de training gaven aan dat zij het voeren van sollicitatiegesprekken niet moeilijk vonden. Deze inschatting kwam niet overeen met de beoordeling van de sollicitatievaardigheden. De vrouwelijke sollicitanten werden op enkele punten positiever beoordeeld.

Onduidelijk blijft echter hoe dit positief toekomstbeeld tot stand komt. Gaat het om een realistische afweging van kansen en mogelijkheden of is hier sprake van het Ratelbandfenomeen: 'als je wil maar sterk genoeg is, kun je iets bereiken'? Het lijkt aannemelijk dat beide aspecten een rol spelen: een inschatting van de mogelijkheid om een bepaalde baan te krijgen, gebeurt nooit alleen op basis van feitelijke informatie maar ook als gevolg van de successen die men in het verleden heeft behaald (Hall, 1976).

Er is een verschil gevonden tussen mannen en vrouwen op de twee variabelen die beide direct van invloed zijn op het krijgen van een baan, namelijk de omvang van het dienstverband en self-efficacy. Mannen willen vaker dan vrouwen een full-time baan, en verwachten sterker de gewenste baan te kunnen realiseren. Hierin zou de verklaring kunnen liggen dat binnen deze groep een 
tendens was te zien dat een kleiner percentage vrouwen een baan heeft in vergelijking met het percentage mannen.

Sociale vaardigheden en leidinggevende kwaliteiten blijken samen te hangen met het vinden van een baan, maar komen in het verklaringsmodel niet terug. In de fase van baanverwerven blijken deze vaardigheden uiteindelijk van ondergeschikt belang te zijn.

Zelfwaardering blijkt een indirecte rol te spelen, via self-efficacy. lemand met een hoge zelfwaardering ziet zichzelf als een capabel en gewaardeerd persoon en verwacht sterk de gestelde doelen te kunnen realiseren. Deze houding vergroot blijkbaar de kans te worden aangenomen voor de functie. 


\section{6}

\section{Eerste werkervaringen}

Als de fase van het verwerven van een baan succesvol is afgerond start een nieuwe fase: de periode van de eerste werkervaringen. Gemiddeld duurt deze periode vier tot zes maanden (Josefowitz \& Gadon, 1988). De fase van de eerste werkervaringen wordt gekenmerkt door hoge verwachtingen ten aanzien van de werksituatie en onzekerheid die samenhangt met het onbekende van de situatie. De eerste ervaringen zijn erop gericht om het werk te waarderen. Men wil graag tevreden zijn over de baan en zal zich zodanig opstellen dat dit wordt bevorderd. Door de nieuwe situatie is men extra gevoelig voor indrukken. Nieuwe ervaringen kunnen positief of negatief zijn. In het ideale geval zullen de ervaringen overwegend positief zijn. Negatieve ervaringen zullen betrekking hebben op relatief onbelangrijke aspecten. In een nieuwe baan kan men ook zogenaamde verrassingen ervaren (Louis, 1980). Verrassingen geven een discrepantie aan tussen de verwachtingen die men had van de situatie en de realiteit. Vooral in de eerste baan na afstuderen zal iedereen het fenomeen verrassingen herkennen. Zelfs bij een intensieve voorbereiding zullen sommige zaken toch anders uitpakken dan men had verwacht. Ook kan het zijn dat men verrast is over zichzelf; dat men nieuwe kanten van zichzelf ziet in de werksituatie. Verder heeft men in de eerste tijd in de nieuwe baan behoefte aan ondersteuning en begeleiding van de chef en van directe collega's. Sociale steun wordt genoemd als één van de factoren die van belang zijn bij stresshantering. We mogen verwachten dat een goede ondersteuning en begeleiding van belang is voor de waardering van de baan.

Ook het krijgen van feedback op de werkzaamheden is essentieel in de beginperiode in een nieuwe baan. Door middel van feedback worden de verwachtingen van de kwaliteit van het werk duidelijk gemaakt. Josefowitz en Gadon (1988) noemen de beperkte mate van feedback die men krijgt op het werk een belangrijk verschil met de situatie als student. Tijdens de studie krijgt men regelmatig feedback. Een introductieprogramma dient ertoe de nieuwkomer wegwijs te maken in de organisatie en met het werk. Een goede introductie biedt de nieuwe werknemer de gelegenheid kennis te maken met de organisatie, haar geschiedenis, de normen en waarden die er heersen; en met de taken en verantwoordelijkheden.

De overgang van de opleiding naar de arbeidsmarkt impliceert een rolverandering van student naar werknemer. Deze rolverandering kan verschillend wor- 
den ervaren. Mogelijk heeft de student in de eindfase van de studie geanticipeerd op de toekomstige nieuwe rol van werknemer. Ook in de stage heeft men vaak al verantwoordelijkheid gedragen waardoor de rolveranderingen niet abrupt worden ervaren. Bij een abrupte overgang van de opleiding naar de arbeidsmarkt zal de rolverandering van student naar werkende veel energie vragen die niet aan de inhoud van het werk kan worden besteed.

De mate van uitdaging in het werk is van belang voor de tevredenheid over de baan (Hall, 1976). De mate van uitdaging moet optimaal zijn; dat wel zeggen niet teveel en niet te weinig uitdaging. Een moeilijke taak die wel is op te lossen vormt een optimale uitdaging. Een onmogelijke opgave is niet meer uitdagend.

Verder is het van belang in hoeverre de baan overeenkomt met de meest gewenste functie. Als men de functie heeft kunnen realiseren die men tevoren het liefst wilde, zal men erg gemotiveerd zijn om te slagen in die baan.

In de beginperiode is de situatie het meest moeilijk. Het aanpassingsproces kost veel energie en men ervaart sterk de negatieve of moeilijke kanten van het werk. Ook spelen processen in organisaties waardoor nieuwkomers op de proef worden gesteld (Josefowitz \& Gadon, 1988). Wanneer men deze beginperiode is gepasseerd, mogen we verwachten dat men een evenwicht hervindt en de waardering voor het werk toeneemt.

Hieronder volgt een beschrijving van de variabelen en een schema met de statistische kenmerken. In dit schema zijn opgenomen: de gemiddelde waarde van de variabelen, de standaarddeviatie, de minimum- en maximumwaarde die in de populatie zijn aangetroffen en het aantal respondenten. De waarden die de variabele kan aannemen staat aangegeven bij de beschrijving van de variabelen. De variabelen zijn allemaal afkomstig uit de derde meting, het carrièreinterview. In totaal zijn 37 personen geïnterviewd, 21 vrouwen en 16 mannen. Bijna tweederde van de geïnterviewden was langer dan een jaar aan het werk, eenderde was korter dan een jaar werkzaam.

\section{Variabelen uit de fase van de eerste werkervaringen}

1. Waardering van de werksituatie. Deze variabele geeft aan in hoeverre men tevreden is over de functie. De variabele kan de waarde 1 tot 5 aannemen, waarbij 1 betekent 'helemaal niet tevreden over de functie' en 5 wil zeggen 'heel erg tevreden over de functie'.

2. Coping gedrag. Deze variabele geeft aan hoe wordt omgegaan met negatieve ervaringen. Dit kan variëren van het aannemen van een afwachtende houding tot het nemen van initiatief om de situatie te veranderen. De waarde loopt van 1 tot 5 .

3. Negatieve ervaringen. Hierbij is gevraagd naar de aard van de negatieve ervaringen. Het gaat hierbij om een inventarisatie van de negatieve ervaringen. In hoeverre was men tevreden over het hanteren van de negatieve ervaringen? De waarde van deze variabele loopt van 1 'ontevreden' tot 5 'tevreden'. 
4. Verrassingen. In de eerste periode in een nieuwe baan komt men vaker voor verrassingen te staan. Verrassingen maken de verwachtingen expliciet die men van te voren had. Het is een indicatie van de discrepantie tussen verwachtingen en de realiteit in de werksituatie. Dit kan betrekking hebben op de baan, de organisatie of het eigen functioneren. Deze variabele geeft aan of er sprake is van een discrepantie. De variabele is dichotoom en kan de waarde 1 of 2 aannemen.

Verder is gevraagd naar de aard van de verrassingen. Dit geeft een beeld van de aspecten waarop men niet is voorbereid.

5. Ondersteuning en begeleiding. Deze variabele geeft aan in hoeverre men ondersteuning en begeleiding krijgt op het werk. Gevraagd wordt naar de mate waarin men tevreden is over de verkregen ondersteuning en begeleiding. De waarde van de variabele varieert van 1 'helemaal niet tevreden' tot 5 'heel erg tevreden'.

6. Introductie. Gevraagd werd of er in de organisatie extra tijd wordt besteed aan nieuwkomers. In hoeverre was men tevreden over de inwerkperiode? De tevredenheid over de inwerkperiode wordt aangegeven door ja (2) of nee (1). 7. Feedback. Dit is een indicatie voor de mate van feedback die men krijgt op het werk. Gevraagd wordt in hoeverre men tevreden is over de feedback op het functioneren. De waarde van de variabele varieert van 1 'helemaal niet tevreden' tot 5 'heel erg tevreden'. Eveneens is gevraagd naar een toelichting op het antwoord.

8. Rolverandering. De overgang van de opleiding naar de arbeidsmarkt impliceert een rolverandering van student naar werkende. Voor sommigen verloopt deze verandering geleidelijk, anderen ervaren de verandering als abrupt. Deze variabele geeft aan hoe de rolverandering wordt ervaren, variërend van meer geleidelijk tot abrupt. De variabele is dichotoom en kan de waarde 1 'geleidelijk' of 2 'abrupt' aannemen.

9. Periode werkzaam in de functie. In de beginperiode is de stress waarschijnlijk hoger dan na enige tijd werkzaam te zijn in de organisatie. De periode varieert van korter dan een half jaar (1) tot langer dan een jaar (3) verbonden zijn aan de organisatie.

10. Uitdaging. Een bepaalde mate van uitdaging in de baan is belangrijk bij leveren van prestaties en het ervaren van succes. Gevraagd is naar de mate waarin men de functie uitdagend vindt. De waarde varieert van 1 'ontevreden' tot 5 'tevreden'.

11. Functievoorkeur. Voor het afstuderen heeft men een voorkeur voor een bepaalde functie aangegeven. In hoeverre is men er in geslaagd deze voorkeur te realiseren? Deze variabele geeft aan of de huidige functie geheel of gedeeltelijk overeenkomt men de functievoorkeur. De waarde varieert van 1 tot 3 . 


\begin{tabular}{lrrrrr}
\hline \multicolumn{1}{c}{ variabele } & gem. & s.d. & min. & max. & $\mathrm{n}$ \\
\hline 1. waardering baan & 4.19 & .65 & 3 & 5 & 31 \\
2. coping gedrag & 3.35 & 1.39 & 1 & 5 & 34 \\
3. negatieve ervaringen & 3.91 & 1.51 & 1 & 5 & 33 \\
4. verrassingen & -- & -- & 1 & 2 & 35 \\
5. sociale steun & 3.27 & 1.21 & 1 & 5 & 33 \\
6. introductie & -- &.-- & 1 & 2 & 25 \\
7. feedback & 2.83 & .99 & 1 & 4 & 30 \\
8. rolverandering & -- & -- & 1 & 2 & 33 \\
9. periode werkzaam & 2.57 & .60 & 1 & 3 & 37 \\
10. uitdaging & 4.30 & 1.18 & 1 & 5 & 37 \\
11. functievoorkeur & 2.43 & .81 & 1 & 3 & 35 \\
12. geslacht & -- &.- & 1 & 2 & 37 \\
& & & & & \\
\hline
\end{tabular}

\section{Kenmerken van de fase van de eerste werkervaringen}

In deze paragraaf wordt beschreven hoe de respondenten te typeren zijn op de verschillende variabelen. De gegevens zullen worden geillustreerd met uitspraken van de geïnterviewden.

Allereerst wordt gekeken naar de afhankelijke variabele in deze fase: de waardering van de werksituatie. Daarna wordt ingegaan op de rol van cognities, de omgevingskenmerken, de overgangskenmerken en de functiekenmerken tijdens de fase van de eerste werkervaringen.

Hoe waarderen de geïnterviewden hun baan? Over het algemeen is de waardering voor de baan hoog. De antwoordcategorieën: erg ontevreden en tamelijk ontevreden komen niet voor. In de volgende tabel staan de resultaten beschreven.

Tabel 6.2: Waardering voor de functie $(n=31)$

\begin{tabular}{lllr}
\hline & mannen & vrouwen & totaal \\
\cline { 2 - 4 } & & & \\
1. gedeeltelijk tevreden/ontevreden & $2(13 \%)$ & $2(13 \%)$ & $4(13 \%)$ \\
2. tamelijk tevreden & $9(60 \%)$ & $8(50 \%)$ & $17(55 \%)$ \\
3. heel erg tevreden & $4(27 \%)$ & $6(37 \%)$ & $10(32 \%)$ \\
$x^{2}=.43, d f=4$, n.s. & & & \\
\end{tabular}


Van de respondenten geeft $13 \%$ aan gedeeltelijk tevreden/gedeeltelijk ontevreden te zijn over de baan. Ruim de helft van de werkenden (55\%) is tamelijk tevreden over de functie. Ruim eenderde van de respondenten is heel erg tevreden over de baan. Er is geen significant verschil tussen mannen en vrouwen wat betreft de waardering van de baan. Zowel mannen als vrouwen zijn overwegend tamelijk tot erg tevreden over hun baan.

\section{cognities}

In stressmodellen spelen cognities een belangrijke rol. Het gaat niet alleen om kenmerken van de feitelijke situatie maar ook om de wijze waarop men deze situatie waarneemt en interpreteert. De beginperiode in een nieuwe baan vormt meestal een onzekere en onduidelijke situatie. Sommige werknemers zullen dit als negatief ervaren en hebben behoefte aan meer duidelijkheid van hun chef en collega's, anderen zullen er ook positieve kanten in zien. Men kan zo'n situatie echter ook beschouwen als kansrijk, vol nieuwe mogelijkheden. Hall (1976) geeft aan dat functieveranderingen in organisaties niet altijd als negatief worden ervaren. Er zijn ook positieve aspecten te herkennen aan veranderingen. Dit geldt met name bij veranderingen van functie in dezelfde organisatie. Pas afgestudeerden zouden deze situatie als overwegend negatief kunnen ervaren. Zij hebben geen of weinig ervaring in organisaties en de onbekendheid van de situatie zal veel groter zijn dan bij overgangen in dezelfde organisatie (Josefowitz \& Gadon, 1988).

Wat betreft de cognities van nieuwkomers in organisaties is gekeken naar positieve en negatieve ervaringen en de wijze waarop hiermee is omgegaan. Verder is gevraagd naar verrassingen. In hoeverre spelen verrassingen een rol voor nieuwkomers? Waardoor worden nieuwkomers verrast?

In de volgende tabel worden de positieve ervaringen weergegeven. Gemiddeld noemt iedereen bijna twee positieve ervaringen uit de eerste periode in de baan. Wat is de aard van deze ervaringen?

Tabel 6.3: Positieve ervaringen $(n=37)$

$\underline{\text { mannen vrouwen aantal }}$

1. samenwerking met collega's; werksfeer

2. ervaren eigen kwaliteiten

3. geaccepteerd en gewaardeerd worden 3

4. inhoud van het werk

5. vrijheid, zelfstandigheid

totaal

30

$\begin{array}{rr}12 & 22 \\ 6 & 11 \\ 8 & 11 \\ 4 & 11 \\ 3 & 8\end{array}$

33

63 
Een prettige samenwerking met collega's en een goede werksfeer vormt de belangrijkste bron van positieve ervaringen. Een van de geïnterviewde formuleert als volgt: De werksfeer is positief; een kleine afdeling met fijne collega's. Geen bureaucratische sfeer. De organisatiecultuur is positief. Het leren kennen van eigen kwaliteiten is ook een bron van positieve ervaringen. Ik merkte dat ik vaardigheden had om initiatief te nemen om iets anders te doen. Ik deed veel contacten op in korte tijd. Een aantal geïnterviewden gaf aan het prettig te vinden te worden geaccepteerd en gewaardeerd, zowel in vorm van complimenten over het werk als in financiële zin. Ik voelde me meteen geaccepteerd en gewaardeerd in de dingen die ik deed. Ook als jong meisje tegenover een burgemeester bijvoorbeeld. Ook de inhoud van het werk leverde aangename verrassingen: $/ k$ vond het onderwijs leuk; het contact met studenten, je verdiepen in je eigen vakgebied. Verder vond men de vrijheid en zelfstandigheid in het werk prettig.

Vrouwen geven in verhouding vaker dan mannen aan dat zij het positief vinden dat ze gewaardeerd en geaccepteerd worden in het werk. Blijkbaar wordt dit niet vanzelfsprekend gevonden. Mannen noemen in verhouding vaker de inhoud van het werk als een positieve ervaring. Ook rapporteren zij iets vaker de vrijheid en zelfstandigheid in het werk als positief.

De meesten zijn tevreden over de manier waarop zij met deze positieve ervaringen zijn omgegaan. Slechts een op de tien zou dat, achteraf gezien, anders hebben gedaan. De meeste geïnterviewden geven aan dat ze er blij mee waren en ervan hebben genoten. Sommigen realiseren zich dat ze de positieve aspecten niet zo bewust hebben beleefd.

Er zijn bijna evenveel negatieve ervaringen genoemd als positieve. ledereen noemde gemiddeld bijna twee ervaringen. Wat waren de negatieve ervaringen in de beginperiode van de baan?

Tabel 6.4: Negatieve ervaringen $(n=37)$

\begin{tabular}{|c|c|c|c|}
\hline & mannen & vrouwen & aantal \\
\hline 1. begeleiding/inwerkperiode & 11 & 11 & 22 \\
\hline 2. werkdruk, onzekerheid, ritme vinden & 5 & 9 & 14 \\
\hline 3. politiek spel & 5 & 6 & 11 \\
\hline 4. teveel vrijheid, verantwoordelijkheid & - & 8 & 8 \\
\hline 5. randvoorwaarden & 4 & 3 & 7 \\
\hline totaal & 25 & 37 & 62 \\
\hline
\end{tabular}

De meeste negatieve ervaringen hebben betrekking op de slechte begeleiding en het ontbreken van een inwerkperiode. De allereerste dag was er niemand die je opving, je werd niet geïntroduceerd, maar meteen ervoor gegooid. Een 
aantal geïnterviewden gaf aan de werkdruk erg hoog te vinden en problemen te hebben met het vinden van een ritme en regelmaat in de nieuwe situatie als werkende. Er wordt direct zoveel van je verwacht. Het politieke spel in de organisatie was ook een bron van negatieve ervaringen. In Maastricht werd ons geleerd om toe te werken naar een doel. In een organisatie is dit niet ieders doelstelling. Door machtsspelletjes wordt gigantisch tegengewerkt ... De grote mate van vrijheid had ook een duidelijke negatieve kant. Er bleek soms onduidelijkheid over taken en verantwoordelijkheden. De vrijheid was soms te groot. Het onderzoeksvoorstel was erg vaag. Het was leuk maar moeilijk en ik wist niet waar ik moest beginnen. Slechte randvoorwaarden vormden ook een bron van ergernis: Gesodemieter om een kamer te krijgen. Ik kon nergens zitten, er waren geen stukken klaar. Ik werd aan mijn lot overgelaten. Het was slecht geregeld.

Vrouwen noemen in verhouding vaker de onzekerheid in het begin als een negatieve ervaring. Opvallend is dat de hoge mate van vrijheid en verantwoordelijkheid alleen door vrouwen wordt genoemd als een negatieve ervaring. In totaal rapporteren vrouwen meer negatieve ervaringen dan mannen.

Er zijn verschillende mogelijkheden om met negatieve ervaringen om te gaan: actief aanpakken en zelf initiatieven nemen; de zaak bespreken op het werk en thuis; afwachten en hopen dat de oplossing vanzelf komt; of emoties uiten (Schaufeli, 1990). In de volgende tabel staat aangegeven welke copingstrategie door de geïnterviewden werd gehanteerd.

Tabel 6.5: Coping negatieve ervaringen $(n=34)$

\begin{tabular}{lllr}
\hline & & & \\
& mannen & vrouwen & \multicolumn{1}{c}{ totaal } \\
\cline { 2 - 4 } & $2(14 \%)$ & $2(10 \%)$ & $4(12 \%)$ \\
1. afwachten, op zijn beloop laten & $1(7 \%)$ & $5(25 \%)$ & $6(18 \%)$ \\
2. eerst afwachten, dan bespreken & $4(29 \%)$ & $4(20 \%)$ & $8(23 \%)$ \\
3. bespreken & $3(21 \%)$ & $3(15 \%)$ & $6(18 \%)$ \\
4. boosheid en verzet uiten & $4(29 \%)$ & $6(30 \%)$ & $10(29 \%)$ \\
5. initiatief nemen; zelf bepalen & & & \\
$x^{2}=2.07, \mathrm{df}=4$, n.s. & & \\
\end{tabular}

Zelf initiatief nemen om de situatie meer naar de hand te zetten, werd het meest genoemd als coping strategie. Een geïnterviewde geeft aan: $/ k$ heb mijn eigen weg gezocht. Vaak werd gekozen om de zaak bespreekbaar te maken: Ik heb geprobeerd op een nette manier er iets van te zeggen wanneer het mij betrof. Afwachten en de zaak op zijn beloop laten, werd soms genoemd. Wat rust proberen te vinden in het feit dat het zo is. Mezelf meer aanpassen dan de baan te veranderen. Bureaucratische dingen kun je niet echt veranderen. Soms ging men over tot het uiten van boosheid; niet altijd met het gewenste 
resultaat. Ik ging naar mijn begeleider, was boos en zei dat ik meer geïnformeerd had moeten worden. Ik verwachtte dat hij erop af zou stappen, dat deed hij niet.

Soms werd gekozen voor de combinatie van het bespreken van de kwestie en daarbij tegelijkertijd de situatie op zijn beloop laten.

Ruim de helft $(61 \%)$ van de respondenten is tevreden over de manier waarop zij de negatieve ervaringen hebben gehanteerd. $40 \%$ is geheel of gedeeltelijk ontevreden over de manier waarop zij dit hebben aangepakt.

Aan de geïnterviewden is gevraagd of ze door bepaalde aspecten van de baan, de organisatie of zichzelf zijn verrast. Het merendeel van de respondenten $(83 \%)$ herkent het fenomeen verrassingen in de beginperiode van de baan. Slechts $17 \%$ geeft aan niet verrast te zijn door bepaalde gebeurtenissen. Waardoor is men zoal verrast? Dit staat weergegeven in tabel 6.6.

Tabel 6.6: Verrassingen $(n=29)$

\begin{tabular}{lrrrr}
\hline & positief & negatief & neutraal & totaal \\
\cline { 2 - 5 } & & & & \\
1. organisatie; organisatiecultuur & 1 & 22 & 3 & 26 \\
2. eigen capaciteiten en werkstijl & 13 & 6 & 1 & 20 \\
3. inhoud van het werk & 3 & 4 & 2 & 9 \\
4. randvoorwaarden & - & 2 & 1 & 3 \\
5. niet verrast & - & - & - & 5 \\
$\quad$ totaal & & & & 63 \\
\hline
\end{tabular}

De meeste verrassingen hadden betrekking op de organisatie en de organisatiecultuur. Sommigen zijn verrast door de slechte samenwerking: Ik merkte dat er concurrentie was. Soms tegen elkaar, niet samenwerken zoals in de studententijd. Verder werd vaak genoemd dat men verrast was door eigen capaciteiten. Meestal betrof dit positieve verrassingen ( $11 \mathrm{keer})$, soms ging het om negatieve verrassingen ( 6 keer). Positief: Je leert je verborgen talenten kennen, zoals organiseren. Voorbeeld van een negatieve verrassing: Je wordt geconfronteerd met eigen tekortkomingen. Ik voelde me onzeker ...

De inhoud van het werk was ook een bron van verrassingen. De inhoud van het werk verraste me het meest. Er kwam meer bij kijken dan ik van tevoren dacht: bijvoorbeeld begeleiding van medewerkers op de werkplek en het voeren van functioneringsgesprekken. Sommigen noemden randvoorwaarden: In ons bureau was geen literatuurvoorziening; er werd geteerd op ervaring en kennis.

Samenvattend: door de respondenten worden zowel positieve als negatieve ervaringen genoemd in de eerste periode in de nieuwe baan. Positieve ervarin- 
gen hebben vooral betrekking op de werksfeer en de plezierige samenwerking met collega's. Negatieve ervaringen zijn vooral het ontbreken van een adequate begeleiding en een introductie op de werkplek. Een actieve opstelling overheerst om deze ervaringen te hanteren. Nieuwkomers werden met name verrast door de organisatiecultuur en ook door eigen kwaliteiten.

\section{omgevingskenmerken}

Een tweede belangrijke aspect van de beginperiode in de eerste baan heeft betrekking op kenmerken van de omgeving. In hoeverre krijgt de nieuwkomer steun van de omgeving? Een drietal relevante variabelen is onderscheiden met betrekking tot omgevingskenmerken: ondersteuning en begeleiding op de werkplek, feedback op de werkzaamheden en de inwerkperiode.

In hoeverre is men tevreden over de ondersteuning en begeleiding die men krijgt? In tabel 6.7 zijn de resultaten opgenomen. In deze tabel is eveneens de mate waarin men tevreden is over de feedback opgenomen.

Tabel 6.7: Tevredenheid over ondersteuning en begeleiding $(n=33)$ en tevredenheid over feedback $(n=30)$

\begin{tabular}{|c|c|c|c|c|c|c|}
\hline \multirow{7}{*}{$\begin{array}{l}\text { erg ontevreden } \\
\text { tamelijk ontevreden } \\
\text { gedeeltelijk ontevr/tevr } \\
\text { tamelijk tevreden } \\
\text { erg tevreden }\end{array}$} & \multicolumn{3}{|c|}{ ondersteuning en begeleiding } & \multirow[b]{2}{*}{ mannen } & \multirow{2}{*}{$\frac{\text { feedback }}{\text { vrouwen }}$} & \multirow[b]{2}{*}{ totaal } \\
\hline & mannen & vrouwen & totaal & & & \\
\hline & $1 \quad\langle 7 \%\rangle$ & $1 \quad(6 \%)$ & $2(6 \%)$ & $1 \quad(7 \%)$ & $2(13 \%)$ & $3(10 \%)$ \\
\hline & $3(21 \%)$ & $5(26 \%)$ & $8(24 \%)$ & $4(29 \%)$ & $4(25 \%)$ & $8(27 \%)$ \\
\hline & $5(36 \%)$ & $8(16 \%)$ & $8(24 \%)$ & $5(35 \%)$ & $5(31 \%)$ & $10(33 \%)$ \\
\hline & $4(29 \%)$ & $5(26 \%)$ & $9(28 \%)$ & $4(29 \%)$ & $5(31 \%)$ & $9(30 \%)$ \\
\hline & $1(7 \%)$ & $6(26 \%)$ & $6(18 \%)$ & - & - & - \\
\hline & $x^{2}=3.09$ & $\mathrm{df}=4$ & & $x^{2}=.31$ & $f=3, n . s$ & \\
\hline
\end{tabular}

In het algemeen is men niet onverdeeld positief over de begeleiding en ondersteuning. Eenderde van de geïnterviewden geeft aan ontevreden te zijn over de ondersteuning en begeleiding. Eenvierde zegt gedeeltelijk ontevreden en gedeeltelijk tevreden te zijn. Bijna de helft van de respondenten $(46 \%)$ is tamelijk of erg tevreden over de begeleiding. Hierbij wordt vaak opgemerkt dat daarbij wel zelf initiatief moet worden genomen. Ik ben heel erg tevreden. Je kunt naar iemand toestappen, je kunt vragen of mensen mee willen denken over bepaalde oplossingen. Ze zijn altijd bereid ondersteuning te geven: vragen er ook zelf naar.

In welke mate is men tevreden over de feedback op de werkzaamheden? Geïnterviewden geven aan grotendeels ontevreden te zijn over de feedback die men krijgt. Ruim eenderde is tamelijk ontevreden of erg ontevreden hier- 
over. Uit de toelichting die geïnterviewden op hun antwoorden geven, blijkt dat feedback in veel gevallen ontbreekt, zelfs als er expliciet om wordt gevraagd. In functioneringsgesprekken wordt vage feedback gegeven die onbruikbaar is. Bijvoorbeeld: Je doet het goed en je bent een aardige meid. Eveneens eenderde is gedeeltelijk ontevreden en gedeeltelijk tevreden over de feedback. Slechts eenderde is tamelijk tevreden over de verkregen feedback. Ik heb een keer per maand overleg met het afdelingshoofd. Verder heb ik een enkele keer achteraf geëvalueerd met mensen met wie ik samenwerk. In welke mate is er aandacht besteed aan de inwerkperiode op de werkplek? In de volgende tabel staan de gegevens vermeld.

Tabel 6.8: Was er sprake van een inwerkperiode? $(n=37)$

\begin{tabular}{lrrr}
\hline & mannen & vrouwen & \multicolumn{1}{c}{ totaal } \\
\cline { 2 - 4 } 1. ja & $8(50 \%)$ & $7(35 \%)$ & $15(42 \%)$ \\
2. nee & $8(50 \%)$ & $13(65 \%)$ & $21(58 \%)$ \\
$x^{2}=.82, \mathrm{df}=1$, n.s. & & & \\
\hline
\end{tabular}

Minder dan de helft van de geïnterviewden gaf aan dat er extra tijd werd besteed aan het inwerken van nieuwe medewerkers in de organisatie. De inwerkperiode varieerde van een rondleiding op de eerste dag met de mogelijkheid tot het stellen van vragen tot een speciale introductie van 3 weken over het bedrijf, waarin gesprekken werden gevoerd met medewerkers van verschillende afdelingen. Voor $58 \%$ van de respondenten ontbrak elke vorm van inwerken. Het kwam erop neer: zoek het maar uit.

Slechts eenderde van de geïnterviewden geeft aan tevreden te zijn over de inwerktijd (tabel 6.9). Voor een groep van $64 \%$ is dit niet het geval. Achteraf wordt vaak duidelijk wat men heeft gemist tijdens de inwerkperiode. Wat ik nu denk dat belangrijk is: voorstellen aan mensen binnen en buiten het instituut, met sleutelfiguren praten. Meegenomen worden door iemand. Contacten zijn belangrijk, die zouden gemakkelijker gelegd kunnen worden. Duidelijk zou moeten worden, bij wie je wat kunt halen. Mannen zijn in verhouding vaker ontevreden over de inwerkperiode dan vrouwen.

Samenvattend: Opvallend is de negatieve waardering voor de omgevingskenmerken die in het onderzoek zijn betrokken. Ruim de helft van de geïnterviewden is geheel of gedeeltelijk ontevreden over de ondersteuning en begeleiding in het werk. De ontevredenheid over de feedback die men krijgt op het werk is nog groter. $70 \%$ geeft aan geheel of gedeeltelijk ontevreden te zijn over de verkregen feedback. Voor een grote groep $(58 \%)$ ontbreekt een inwerkperiode. 


\begin{tabular}{llrr} 
& mannen & vrouwen & totaal \\
\cline { 2 - 4 } & $9(82 \%)$ & $7(50 \%)$ & $16(64 \%)$ \\
1. nee & $2(18 \%)$ & $7(50 \%)$ & $9(36 \%)$ \\
$x^{2}=2.70, \mathrm{df}=1, \mathrm{p}=.09$, n.s. & & & \\
\hline
\end{tabular}

\section{overgangskenmerken}

Twee variabelen hebben betrekking op kenmerken van de overgangssituatie: rolverandering en de periode dat men werkzaam is in de functie.

De overgang van de opleiding naar de arbeidsmarkt vereist een verandering van rol. Namelijk een verandering van de rol van student in de rol van werknemer. Niet iedereen kan zich deze nieuwe rol gemakkelijk eigen maken. Soms moet men in de nieuwe rol groeien.

De meesten herkennen het fenomeen van rolverandering bij de overgang van de opleiding naar de arbeidsmarkt. Slechts een persoon geeft aan géén rolverandering te hebben ervaren. Zij merkt op: De studententijd liep als het ware door. Ik ben hetzelfde blijven doen. Ik ervaar het niet als een belasting om elke dag te werken. Als student studeerde ik ook elke dag. Nu ben ik na het werk echt vrij. De meesten (namelijk $97 \%$ ) geven aan wél een verandering van rol te ervaren. In tabel 6.10 staan de meest genoemde kenmerken van de rolverandering van student naar werkende.

Tabel 6.10: Kenmerken van rolverandering $(n=36)$

\begin{tabular}{lccc}
\hline & mannen & vrouwen & totaal \\
\cline { 2 - 4 } 1. meer verantwoordelijkheid & 9 & 8 & 17 \\
2. minder vrijblijvend/ & & 11 & 17 \\
3. meer verplichtingen & 6 & 8 & 14 \\
minder vrije tijd/ vakantie & 6 & 5 & 8 \\
4. andere financiële positie & 3 & 3 & 7 \\
5. meer regelmaat & 4 & 3 & 5 \\
6. meer plannen & 2 & 2 & 5 \\
7. maatschappelijke positie & 3 & & 73 \\
totaal & 33 & 40 & \\
\hline
\end{tabular}

De grotere mate van verantwoordelijkheid en het minder vrijblijvende karakter van een baan worden het meest genoemd als kenmerken van rolverandering. 
De beperkte vrije tijd is eveneens een groot verschil met de rol als student. De financiële positie wordt meestal in positieve zin genoemd; twee keer in meer neutrale betekenis: Het gaat net zo makkelijk op ... Meer regelmaat en de noodzaak om strakker te plannen worden ook vaker genoemd. Sommigen noemen een betere maatschappelijke positie en meer status als werkende: Je hebt een bepaald maatschappelijk aanzien als je werkt. Er zijn nauwelijks verschillen tussen de kenmerken van rolverandering zoals die zijn genoemd door mannen en vrouwen. Wel noemen vrouwen vaker het minder vrijblijvende karakter van de werksituatie.

Voor $58 \%$ van de geïnterviewden is de verandering meer geleidelijk verlopen (tabel 6.11). De afstudeerperiode was ook een werkstage. Ik werkte van 8 tot 5. Ik heb er echt naartoe geleefd om werk te krijgen.

Door $42 \%$ werd de verandering van student naar werkende als abrupt ervaren. Zodra het werk begon, begonnen de veranderingen. Vooral toen ik naar Maastricht kwam. Een andere geïnterviewde merkt op: Ik had er in mijn hoofd rekening mee gehouden, maar als het dan daadwerkelijk gebeurt is de overgang groot.

Tabel 6.11: Rolverandering $(n=33)$

\begin{tabular}{lrrr} 
& mannen & vrouwen & \multicolumn{1}{c}{ totaal } \\
\cline { 2 - 4 } 1. meer geleidelijk & $8(53 \%)$ & $11(61 \%)$ & $19(58 \%)$ \\
2. meer abrupt & $7(47 \%)$ & $7(39 \%)$ & $14(42 \%)$ \\
$x^{2}=.20, \mathrm{df}=1$, n.s. & & & \\
\hline
\end{tabular}

De periode waarin men werkzaam is in de nieuwe baan wordt beschouwd als één van de overgangskenmerken. Het blijkt dat een kleine groep van $6 \%$ korter dan een half jaar werkt in de functie, $32 \%$ is gedurende 6 maanden tot een jaar werkzaam in de baan en het merendeel, namelijk $62 \%$, werkt langer dan een jaar in de huidige baan.

Samenvattend: De rolverandering van student naar werkende wordt vooral gekenmerkt door het ervaren van meer verantwoordelijkheid en het hebben van meer verplichtingen. De vrije tijd is afgenomen. Voor ruim de helft van de respondenten is de overgang geleidelijk verlopen. Vrouwen rapporteren vaker het minder vrijblijvende karakter van de werksituatie dan mannen.

Het merendeel van de geïnterviewden was ruim een jaar werkzaam in de functie. 
functiekenmerken

Enkele functiekenmerken zijn bekeken in de fase van de eerste werkervaringen, namelijk de mate waarin men de baan uitdagend vindt, en de mate waarin de voorkeur voor de functie is uitgekomen.

Hall noemt de mate van uitdaging als onderdeel van de succescyclus. Een passende mate van uitdaging is van belang voor het ervaren van succes in het werk. Wanneer de eerste baan voldoende uitdagend is, zou dit positieve effecten hebben op het verdere verloop van de loopbaan. In hoeverre de functies van de geïnterviewden uitdagend zijn, staat weergegeven in de volgende tabel.

Tabel 6.12: Tevreden over de mate van uitdaging $(n=37)$

\begin{tabular}{lrrr}
\hline & mannen & vrouwen & \multicolumn{1}{c}{ totaal } \\
\cline { 2 - 4 } nee & - & $2(10 \%)$ & $2(6 \%)$ \\
gedeeltelijk & $5(31 \%)$ & $4(19 \%)$ & $9(24 \%)$ \\
ja & $11(69 \%)$ & $15(71 \%)$ & $26(70 \%)$ \\
$x^{2}=2.09, \mathrm{df}=2, \mathrm{n} . \mathrm{s.}$ & & \\
\hline
\end{tabular}

Ruim tweederde van de respondenten is tevreden over de mate van uitdaging in de baan. Slechts $6 \%$ van de geïnterviewden geeft aan ontevreden te zijn. Eenvierde geeft aan gedeeltelijk tevreden te zijn over de mate van uitdaging. In de toelichting geven geïnterviewden aan dat de mate van uitdaging erg wisselend wordt ervaren. Voor sommigen gaat de uitdaging er snel af na de beginperiode. Anderen starten met een heel lage uitdaging en krijgen daarna meer verantwoordelijkheden. Weer anderen ervaren een constante hoge uitdaging. Enkelen geven aan dat uitdagingen ook zelf gecreëerd kunnen worden: Voor een deel wat ik er zelf inleg. Ik kan het leuker maken door zelf onderzoeksvoorstellen te schrijven bijvoorbeeld ...

Wanneer men als student een duidelijk idee heeft voor een toekomstige functie zal men dit eerder weten te realiseren dan wanneer dit niet het geval is. De meeste geïnterviewden zijn geconfronteerd met hun uitspraak als student over de gewenste functie. In hoeverre hebben ze de functie gerealiseerd die ze het liefst zouden willen? De resultaten staan beschreven in tabel 6.13.

Bijna tweederde van de geïnterviewden heeft de baan gekregen waar de voorkeur naar uitging. Slechts eenvijfde geeft aan dat dit niet het geval is. Niet iedereen is daar overigens ontevreden mee: Nee, maar ik vind dit niet slecht. Je kunt niet al te kieskeurig zijn. 


\begin{tabular}{lrrr}
\hline & \multicolumn{1}{c}{ mannen } & \multicolumn{1}{c}{ vrouwen } & \multicolumn{1}{c}{ totaal } \\
\cline { 2 - 4 } nee & $3(20 \%)$ & $4(20 \%)$ & $7(20 \%)$ \\
gedeeltelijk & $2(13 \%)$ & $4(20 \%)$ & $6(17 \%)$ \\
ja & $10(67 \%)$ & $12(60 \%)$ & $22(63 \%)$ \\
$x^{2}=.28, d f=2$, n.s. & & \\
\hline
\end{tabular}

Een groep van $17 \%$ heeft de voorkeur functie gedeeltelijk weten te realiseren. Hierbij gaat het soms om zeer specialistische functies: Gedee/telijk. Eigenlijk afgestudeerd in fytopathologie (schimmels en planteziekte). Ik had verwacht als fytopatholoog te gaan werken, maar dat is niet het geval. Het type baan had ik wel verwacht, namelijk een onderzoeksbaan.

Samenvattend: De meesten (70\%) zijn tevreden over de mate van uitdaging in de baan; in de toelichting op het antwoord worden echter allerlei bedenkingen genoemd. Tweederde van de respondenten is erin geslaagd de baan te krijgen die men ambieerde.

\section{Relaties tussen cognities, omgevingskenmerken, overgangs- kenmerken, functiekenmerken en waardering van de werk- situatie}

Hieronder is de correlatiematrix weergegeven van de onafhankelijke variabelen uit de fase van de eerste werkervaringen (tabel 6.14). Deze variabelen zijn gegroepeerd rond de concepten cognities, omgevingskenmerken, overgangskenmerken en functiekenmerken. Onder cognities vallen drie variabelen, namelijk coping gedrag, omgaan met negatieve ervaringen en herkennen van verrassingen. De coping stijl varieert van afwachten tot actief ingrijpen in de situatie. Deze variabele vertoont geen hoge samenhang met andere variabelen. Wel is er een tendens met de overige variabelen met betrekking tot cognities.

Tevredenheid over het hanteren van negatieve ervaringen hangt sterk samen met de variabele rolverandering. Wanneer de overgang van student naar werkende meer geleidelijk wordt ervaren, is men vaker tevreden over het hanteren van de negatieve ervaringen.

De variabelen die betrekking hebben op omgevingskenmerken zijn: de mate van tevredenheid over sociale steun, de tevredenheid over de introductieperiode en de mate van tevredenheid over feedback. Sociale steun hangt samen met de introductieperiode en met feedback. Blijkbaar zijn dit omgevingsaspecten die op vergelijkbare wijze worden ervaren. Het kan ook zijn dat het hierbij 
gaat om bepaalde kenmerken van de organisatiecultuur. In een organisatie waarin de nieuwkomer steun krijgt, wordt eveneens een introductieprogramma. aangeboden en krijgt men feedback op de werkzaamheden.

Verder blijkt er een samenhang te zijn tussen de tevredenheid over de feedback en de mate waarin de functievoorkeur is uitgekomen. Degenen die de functie hebben gekregen die ze graag willen, zijn in verhouding minder tevreden over de feedback.

De aard van de rolverandering die men heeft ervaren en de periode waarin men werkzaam is in de baan zijn de twee variabelen in de categorie overgangskenmerken. Rolverandering hangt samen met de periode waarin men werkt in de baan: naarmate men langer werkzaam is, beschouwt men de overgang vaker als abrupt. Rolverandering hangt eveneens samen met de uitdaging die men ervaart: naarmate men meer uitdaging ervaart in de baan, is de rolverandering vaker abrupt verlopen. Waarschijnlijk moet men enige tijd in de baan werkzaam zijn om afstand te kunnen nemen van de eerste periode in de baan; pas achteraf herkent men dan de abrupte rolverandering. Veel uitdaging in de baan wordt waarschijnlijk ook als nieuw ervaren en extra contrasterend met de studietijd.

Er zijn geen hoge correlaties met geslacht. Behalve een tendens op de variabele introductieperiode. Vrouwen zijn iets vaker tevreden over de introductieperiode dan mannen. Verder blijken mannen en vrouwen niet te verschillen op de onderzochte variabelen.

Tabel 6.14: Correlatiematrix van de fase van de eerste werkervaringen $(21 \leq n \leq 37)^{3}$

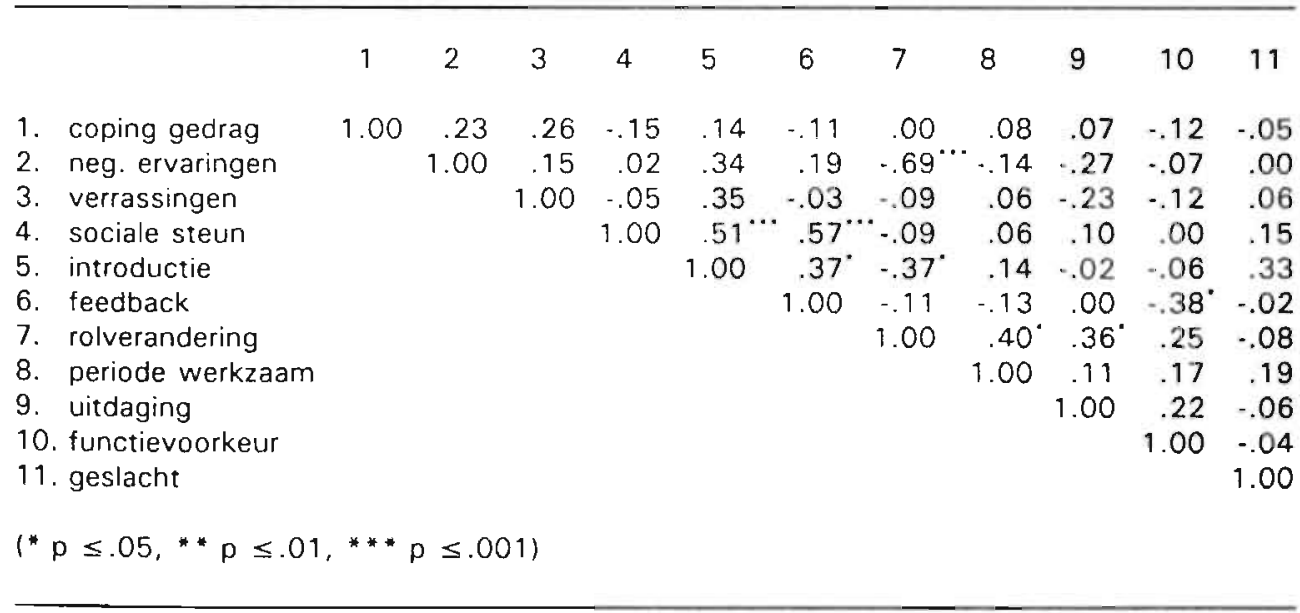

\footnotetext{
${ }^{3}$ De exacte waarde van $n$ per cel van de correlatiematrix staat vermeld in tabel 3 in de bijlage.
} 
In tabel 6.15 zijn de correlaties weergegeven van de onafhankelijke variabelen met de waardering van de werksituatie. De variabelen die betrekking hebben op cognities blijken niet te correleren met de waardering voor de werksituatie. Sociale steun hangt wel sterk samen met de waardering voor de werksituatie. Hoe meer tevreden men is over de sociale steun die men krijgt op het werk, des te tevredener is men over het werk. De mate van tevredenheid over de introductie op het werk vertoont ook samenhang met de waardering van de werksituatie. Tevredenheid over de feedback blijkt eveneens relevant in relatie tot de waardering voor de werksituatie. Blijkbaar zijn deze drie omgevingskenmerken erg bepalend voor de waardering van de functie.

$\mathrm{Er}$ is ook een verband tussen de periode waarin men werkzaam is in de baan en de mate van waardering van de baan. Degenen die kort werkzaam zijn, zijn in hogere mate tevreden over de functie dan degenen die al iets langer werken. De waardering van de functie in de allereerste maanden heeft misschien meer te maken met de tevredenheid over het feit dat men een baan heeft gevonden. Na de spannende sollicitatieperiode kan men aan de slag gaan, en dat zal de hoge waardering voor de functie mede bepalen. Na enige tijd is men goed in staat de balans op te maken en de ervaringen in de baan te evalueren op zijn waarde.

De mate van uitdaging in de baan is eveneens van belang voor de waardering van de functie. Naarmate men meer tevreden is over de uitdaging in de baan, is men meer tevreden over de baan. In een uitdagende baan kan men de capaciteiten goed laten zien.

Tabel 6.15: Correlaties met waardering werksituatie

$\begin{array}{lcc}\text { 1. coping gedrag } & -.09 & (n=28) \\ \text { 2. negatieve ervaringen } & .08 & (n=28) \\ \text { 3. verrassingen } & -.12 & (n=29) \\ \text { 4. sociale steun } & .62^{\circ} & (n=30) \\ \text { 5. introductie } & .50^{\circ} & (n=22) \\ \text { 6. feedback } & .45^{\circ} & (n=27) \\ \text { 7. rolverandering } & -.14 & (n=28) \\ \text { 8. periode werkzaam } & .37^{\circ} & (n=31) \\ \text { 9. uitdaging } & .35^{\circ} & (n=31) \\ \text { 10. functievoorkeur } & .03 & (n=29) \\ \text { 11. geslachit } & .09 & (n=31)\end{array}$

$(* p \leq .05, * * p \leq .01, * * p \leq .001)$ 


\section{Causale modellering van de fase van de eerste werkervaringen}

Evenals bij de rapportage van onze bevindingen in hoofdstuk 4, de voorbereidingsfase, en in hoofdstuk 5, fase van baan verwerven, hebben we de gevonden verbanden tussen variabelen in de fase van de eerste werkervaringen onderworpen aan SEM, het modelleren van structurele vergelijkingen (Bentler, 1995). Voor een korte uitleg van de aard van deze techniek wordt verwezen naar hoofdstuk 4, paragraaf 4 . Hier wordt volstaan met de constatering dat de onderhavige analyses vooral als exploratief moeten worden geduid. Aan de uitkomsten mag dan ook slechts beperkte betekenis worden gehecht.

\section{methode}

De data werden geanalyseerd met behulp van EQS (Bentler, 1995).

\section{resultaten}

In figuur 9 zijn de resultaten van de analyses op grafische wijze weergegeven. Het gepresenteerde model past goed: Chi-kwadraat $=17,44, \mathrm{df}=12, \mathrm{p}=$ $0.13 ; \mathrm{CFI}=0.94$.

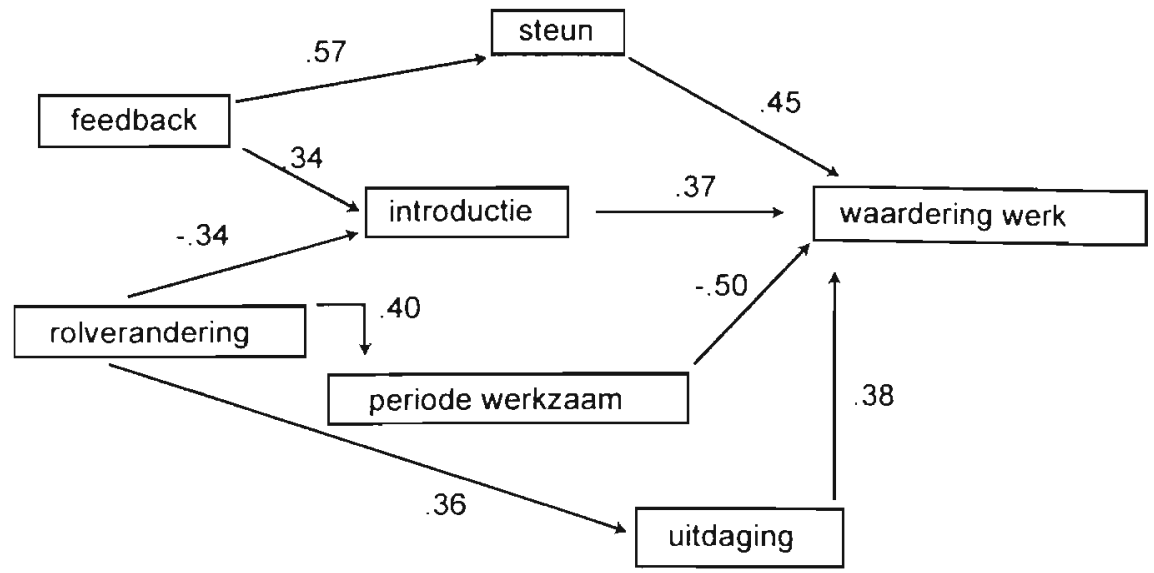

chi-kwadraat $=17.44$, d.f. $=12, p=0.13$

$\mathrm{CFI}=0.94$

Figuur 9: De fase van de eerste werkervaringen $(n=37)$

Uit het model blijkt dat het verkrijgen van sociale steun en de waardering voor de introductieperiode beide direct van invloed zijn op de waardering van de werksituatie. De invloed van beide is positief en aanzienlijk groot; respectievelijk .45 en .37. Feedback is direct van invloed op zowel het verkrijgen van sociale steun (.57) en op de introductieperiode (.34). De periode waarin men werkzaam is in de baan is in sterke mate negatief $(-.50)$ van invloed op de 
waardering voor de functie. De uitdaging die men ervaart in het werk is daarentegen in sterke mate positief van invloed op de waardering van de baan. De padcoëfficiënt bedraagt .38. De wijze waarop men de rolverandering van student naar werknemer heeft ervaren is van invloed op de uitdaging die men ervaart in het werk (.36).

\section{Discussie}

In dit hoofdstuk is de fase van de eerste werkervaringen besproken. Deze fase heeft betrekking op de eerste maanden in de nieuwe baan, waarin men de organisatie leert kennen, en resulteert in een waardering van de werksituatie. Uit het verklaringsmodel van de fase van de eerste werkervaringen blijkt dat de waardering van de baan vooral wordt bepaald door de sociale steun die men krijgt, de introductieperiode, de mate van uitdaging van de baan en de periode waarin men werkzaam is. De mate van tevredenheid over de feedback is indirect van invloed op de waardering voor de baan, via sociale steun en de introductieperiode. De rolverandering die men ervaart is indirect van invloed via de periode waarin men werkzaam is en de uitdaging die men in de baan ervaart.

Omgevingsfactoren blijken cruciaal te zijn in de eerste periode. Zowel het krijgen van sociale steun en feedback en een goede introductieperiode houden verband met de waardering van de werksituatie. De aantrekkelijkheid van een baan wordt in de beginsituatie positief beïnvloed door de samenwerking met collega's, de steun van de baas of de begeleider en de hulp die men krijgt bij het uitvoeren van de taken. Opvallend is dat deze aspecten in de werksituatie van de meeste respondenten nogal te wensen overlaat. Onder het mom van vrijheid in de invulling van de functie en uitdaging in het werk worden nieuwkomers in het diepe gegooid. 'Zwemmen of verzuipen' is op veel plaatsen het motto. De vraag naar de aard van de positieve en negatieve aspecten van de werksituatie wordt ook vaak beantwoord met omgevingskenmerken. De meest genoemde positieve ervaring is de samenwerking met de collega's en de werksfeer; als negatieve ervaring springen het gebrek aan begeleiding en inwerktijd eruit. Respondenten geven aan het meest verrast te zijn door het werken in de organisatie en de organisatiecultuur. Blijkbaar zijn ze hierop totaal niet voorbereid. Josefowitz en Gadon (1988) beschrijven sociaal psychologische processen die een rol spelen wanneer iemand nieuw in een organisatie binnenkomt. De leden van de organisatie vormen een groep waarin de nieuweling een plaats moet veroveren. Groepsleden hebben in eerste instantie de neiging om de nieuwe medewerker buiten te sluiten. Ongewenste opdrachten worden doorgeschoven naar de nieuwkomer: zij worden opgescheept met de minst interessante klussen, de slechtste roosters, de vervelendste cliënten en de oudste computers. Soms vinden ontgroeningspraktijken plaats. Overgangskenmerken zijn eveneens van belang. Met name de periode dat men werkzaam is in de functie blijkt direct van invloed op de waardering voor de 
functie. Hoe korter men werkt in de baan, des te positiever is het oordeel over de betreffende baan. Dit hangt waarschijnlijk samen met het effect van de sollicitatieperiode. Tijdens de sollicitatieperiode geeft de selectiecommissie meestal overwegend positieve informatie over de organisatie en over de baan. Hierdoor worden niet realistische verwachtingen geschept bij de nieuwkomer (Porter et al., 1975). Dit positief beeld dat de organisatie heeft weten te creëren zal overheersen in de eerste tijd dat men werkt. Na enige tijd kan de nieuwkomer de balans opmaken van positieve en negatieve ervaringen op de werkplek. Het resultaat van de reality shock wordt duidelijk: niet alles blijkt even rooskleurig te verlopen in de organisatie dan verwacht. Volgens Hall (1976) is dit de oorzaak van een groot verloop van starters in het eerste jaar dat zij werkzaam zijn. Nieuwkomers zouden hierop meer moeten worden voorbereid en organisaties zouden hierop meer moeten zijn bedacht.

De uitdaging in de functie blijkt erg belangrijk te zijn voor de waardering van de baan. Als de baan uitdagend is, kan de starter zijn of haar capaciteiten tonen. In de toelichting wordt soms genoemd dat de uitdaging te hoog is. Dit verwijst naar een optimaal niveau van uitdaging: moeilijk maar haalbaar. In de uitdaging van de baan speelt blijkbaar het dilemma tussen zelfstandig werken, dat als positief wordt ervaren, en het ontbreken aan coaching om de uitdagende taken goed te kunnen hanteren. Hall (1976) noemt deze verschillende aspecten die bij de waardering van de functie een rol spelen.

Variabelen die betrekking hebben op de cognities blijken in het model geen rol te spelen. Soms waren er wel verschillen te zien tussen mannen en vrouwen bij de toelichting op deze variabelen. Vrouwen noemen bijvoorbeeld het geaccepteerd en gewaardeerd worden in de organisatie vaker dan mannen als een positieve ervaring. Mannen geven vaker aan dat zij de inhoud van het werk als positief ervaren. Bij de negatieve ervaringen valt op dat alleen door vrouwen wordt gerapporteerd teveel vrijheid en verantwoordelijkheid te ervaren. Dit zou erop kunnen wijzen dat vrouwen in hogere mate gevoelig zijn voor de groepsdynamische processen die in de beginsituatie op het werk een belangrijke rol spelen. Het gevoel geaccepteerd te worden, zou erop kunnen duiden dat het socialisatieproces van het individu in de organisatie goed verloopt. Het ervaren van teveel vrijheid en verantwoordelijkheid zou erop kunnen wijzen dat men op de proef wordt gesteld. 



\section{Succes ervaren}

In het begin van de eerste baan wordt de nieuwkomer geconfronteerd met allerlei onverwachte aspecten van de werksituatie. Dit is in het vorige hoofdstuk beschreven. Nadat men gewend is aan het werken in de organisatie kan men zich meer richten op de inhoud van de functie en op het goed vervullen van de taken. In deze fase speelt het ervaren van succes in het werk een belangrijke rol. Na een periode van aanpassing aan de organisatie komt het erop aan een bijdrage te leveren aan de organisatie.

Het ervaren van succes is een indicatie dat de overgang naar de nieuwe baan goed is doorlopen. Welke aspecten kunnen hieraan bijdragen? Bepaalde kenmerken van de functie zouden van belang kunnen zijn. Sommige functies vereisen specialistische kennis, andere functies daarentegen vragen meer algemene kennis en vaardigheden. Volgens Kluytmans (1993) wordt tijdens de selectie en de introduktie vooral aandacht besteed aan specialistische kennis en vaardigheden. De mate van specialisatie van de functie zou dan ook van invloed kunnen zijn op het ervaren van succes.

De mate van autonomie in het uitoefenen van de functie lijkt eveneens relevant. Hall (1976) noemt het autonoom uitoefenen van een taak als onderdeel van de succescyclus. Een hoge mate van autonomie geeft sterk het gevoel van persoonlijke verantwoordelijkheid voor de resultaten (Cummings \& Huse, 1989).

Aspecten die betrekking hebben op zelfmanagement zijn ook van belang voor het ervaren van succes (Mensink, 1994). Een goede planning kunnen maken van de werkzaamheden om de gestelde doelen te bereiken, is hiervoor essentieel. Feedback krijgen op de prestaties geeft aanknopingspunten om de planning bij te stellen.

Loopbaankenmerken spelen mogelijk ook een rol. Het belang dat wordt gehecht aan de loopbaan zal bijdragen aan de motivatie om succesvol te zijn in het werk. Verder zou de periode waarin men werkzaam is in de baan van invloed kunnen zijn. Het zal enige tijd in beslag nemen voordat de nieuwkomer is gewend aan de baan en zelfstandig taken kan uitvoeren. Pas daarna kan succes optreden.

De mate waarin de kennis en vaardigheden uit de opleiding bruikbaar zijn in de werksituatie zal ook een rol spelen. De bruikbaarheid van de beschikbare kennis en vaardigheden zal van invloed zijn op het bereiken van succes. $\mathrm{Na}$ 
de eerste tijd in de baan zal meer gebruik worden gemaakt van nieuwe kennis en vaardigheden (Swieringa \& Wierdsma, 1990).

Hoe zijn de variabelen in deze fase geoperationaliseerd? Hieronder volgt een beschrijving van de variabelen en een tabel met de statistische kenmerken. In deze tabel zijn opgenomen: de gemiddelde waarde van de variabelen, de standaarddeviatie, de minimum- en maximumwaarde die in de populatie zijn aangetroffen en het aantal respondenten. De waarden die de variabele kan aannemen is weergegeven bij de beschrijving van de variabelen. Alle variabelen zijn afkomstig uit de derde meting, het interview. Hieraan hebben 37 respondenten deelgenomen, waarvan 16 mannen en 21 vrouwen.

\section{Variabelen uit de fase van succes ervaren}

1. Succesvol zijn in het werk. Deze variabele geeft aan in hoeverre men zichzelf succesvol vindt in het werk. Het gaat om een subjectieve inschatting van succes. De waarde van de variabele varieert van 1 tot 5 , waarbij 1 staat voor het niet succesvol vinden van zichzelf en 5 wil zeggen dat men zichzelf succesvol vindt.

2. Specialisatie. Hierbij is een onderscheid gemaakt tussen een meer specialistische of een meer generalistische functie. De variabele varieert van 1 tot 5 , waarbij de waarde 1 wil zeggen dat de functie overwegend specialistisch is en de waarde 5 aangeeft dat de functie overwegend generalistisch is.

3. Autonomie. De variabele autonomie geeft aan in hoeverre men tevreden is over de autonomie die men heeft in het werk. De waarde varieert van 1 tot $5 ; 1$ wil zeggen dat men erg ontevreden is over de mate van autonomie in het werk; 5 geeft aan dat men hierover erg tevreden is.

4. Planning. Deze variabele heeft betrekking op de planning van werkzaamheden. In hoeverre verliep de planning over het algemeen gemakkelijk dan wel moeizaam? De waarde kan variëren van 1 tot 5 . De waarde 1 geeft aan dat de planning overwegend moeizaam verliep, 5 wil zeggen dat de planning gemakkelijk verliep. Er is ook toelichting gevraagd bij de aspecten die gemakkelijk, dan wel moeilijk waren.

5. Feedback. Dit is een indicatie voor de mate van feedback die men krijgt op het werk. Gevraagd wordt in hoeverre men tevreden is over de feedback op het functioneren. De waarde van de variabele varieert van 1 (helemaal niet tevreden) tot 5 (heel erg tevreden). Eveneens is gevraagd naar een toelichting op het antwoord.

6. Het belang van de loopbaan. Gevraagd is naar het belang dat men hecht aan een beroepsloopbaan. De waarde varieert van 1 tot 5 , waarbij 1 wil zeggen dat men een beroepsloopbaan erg onbelangrijk vindt. De waarde 5 geeft aan dat men een loopbaan heel erg belangrijk vindt.

7. De periode werkzaam. Deze variabele geeft aan hoelang men werkzaam is in de huidige functie. De periode varieert van korter dan een half jaar (1) tot langer dan een jaar (3) verbonden zijn aan de organisatie. 
8. Kennis. De variabele kennis heeft betrekking op de aansluiting van de kennis op de baan. In hoeverre is men van mening dat de kennis goed aansluit op de baan. De waarde varieert van 1 tot 5 . De waarde 1 staat voor een slechte aansluiting van de kennis; 5 wil zeggen dat van de kennis goed aansluit bij de functie.

9. Vaardigheden. De variabele vaardigheden heeft betrekking op de aansluiting van vaardigheidsonderdelen uit de studie op de functie. De waarde varieert van 1 tot 5 . De waarde 1 wil zeggen dat een goede aansluiting van de vaardigheden op de functie ontbreekt. De waarde 5 geeft aan dat de aansluiting van de vaardigheden op de functie goed is.

10. Geslacht. Verschillen tussen mannen en vrouwen in deze fase worden bekeken.

Tabel 7.1: Statistische kenmerken van variabelen uit de fase van succes ervaren

\begin{tabular}{lccccc}
\hline \multicolumn{1}{c}{ variabele } & gem. & s.d. & min. & max. & $\mathrm{n}$ \\
\hline 1. succes & 4.45 & 1.15 & 1 & 5 & 33 \\
2. aard functie & 2.94 & 1.69 & 1 & 5 & 36 \\
3. autonomie & 4.89 & .46 & 3 & 5 & 37 \\
4. planning & 3.16 & 1.27 & 1 & 5 & 31 \\
5. feedback & 2.83 & .99 & 1 & 4 & 30 \\
6. belang loopbaan & 4.08 & .69 & 3 & 5 & 36 \\
7. periode werkzaam & 2.57 & .60 & 1 & 3 & 37 \\
8. kennis & 3.76 & 1.05 & 1 & 5 & 34 \\
9. vaardigheden & 3.85 & 1.10 & 1 & 5 & 34 \\
10. geslacht & -- & -- & 1 & 2 & 37 \\
& & & & & \\
\hline
\end{tabular}

\section{Kenmerken van de fase van succes}

Succesvol zijn in het werk is gedefinieerd als afhankelijke variabele in deze fase. Het gaat hierbij om een subjectieve inschatting van het succes in het werk. In welke mate zijn de geïnterviewden van mening dat zij succesvol zijn in hun werk? In tabel 7.2 staan de resultaten beschreven.

Viervijfde van de geïnterviewden geeft aan zichzelf succesvol te vinden in het werk. In de toelichting op de antwoorden geeft men soms aan het moeilijk te vinden een maatstaf te nemen. Wat zijn precies de criteria voor succes? Vaak wordt verwezen naar reacties van anderen, soms naar de geluksfactor. 


\begin{tabular}{lrrr}
\hline & mannen & vrouwen & \multicolumn{1}{c}{ totaal } \\
\cline { 2 - 4 } nee & - & $2(9,5 \%)$ & $2(6 \%)$ \\
gedeeltelijk & $3(25 \%)$ & $2(9,5 \%)$ & $5(15 \%)$ \\
ja & $9(75 \%)$ & $17(81 \%)$ & $26(79 \%)$ \\
$\chi^{2}=2.38, \mathrm{df}=2$, n.s. & & \\
\hline
\end{tabular}

Van anderen hoor ik dat het goed gaat. Zelf vind ik dat het gaat zoals het gaat. Ik vind ook dat ik veel mazzel heb gehad. Ik heb dit altijd graag gewild. Geluk om net op de juiste plek te zijn, daarna rolt het verder ...

Enkele vrouwen geven aan zichzelf niet succesvol te vinden, terwijl geen van de mannen dit aangeeft. Overigens is er geen significant verschil tussen mannen en vrouwen in het ervaren van succes.

\section{functiekenmerken}

Twee variabelen zijn beschreven als relevante functiekenmerken in deze fase. Het gaat om de aard van de functie en de mate van autonomie in het werk. Met betrekking tot de aard van de functie is een onderscheid gemaakt tussen een meer specialistische en een meer generalistische functie. In welke mate komen dit type functies voor bij pas afgestudeerden? Zie hiervoor tabel 7.3.

Tabel 7.3: Aard van de functie $(n=36)$

\begin{tabular}{llll}
\hline & & & \\
& & & \\
\cline { 2 - 3 } & & & \\
meer specialistisch & $5(33 \%)$ & $8(38 \%)$ & $13(36 \%)$ \\
ertussen in & $6(40 \%)$ & $5(24 \%)$ & $11(31 \%)$ \\
meer generalistisch & $4(27 \%)$ & $8(38 \%)$ & $12(33 \%)$ \\
$x^{2}=1.15, \mathrm{df}=2$, n.s. & & \\
\hline
\end{tabular}

Ruim eenderde van de geïnterviewden is in een specialistische baan terecht gekomen kort na afstuderen. Eveneens eenderde heeft een functie die niet echt als specialistisch of generalistisch te typeren is. Een generalistische functie wordt door eenderde van de respondenten vervuld. Mogelijk hangt dit relatief hoge aantal specialistische banen samen met het feit dat een grote groep als AIO werkzaam is. Dit kan worden gezien als een specialistische baan. 
Autonomie in het werk is eveneens een belangrijk aspect in de fase van het ervaren van succes. Succes kan alleen dan worden ervaren als resultaten in het werk duidelijk zijn te herleiden tot eigen inspanningen. Gevraagd is naar de mate waarin men tevreden is over de autonomie die men heeft in het werk. Uit de resultaten blijkt dat men hierover erg tevreden is. Van de geïnterviewden zegt namelijk $95 \%$ tevreden te zijn. Uit de toelichting op deze vraag blijkt dat voor een aantal respondenten vooral in de beginperiode sprake was van teveel autonomie. Na de beginperiode wordt de hoge mate van autonomie als positief ervaren.

Samenvattend: Eenderde van de respondenten is in een specialistische functie terecht gekomen, eveneens eenderde heeft een generalistische baan. Vrijwel iedereen geeft aan tevreden te zijn over de autonomie in de functie.

\section{zelfmanagement}

Voor het ervaren van succes is het van belang dat minder positieve ervaringen in het werk worden bijgestuurd. Twee variabelen vallen onder deze categorie. Het gaat om planning van werkzaamheden en het krijgen van feedback.

Met name in de beginperiode in een baan levert het plannen van werkzaamheden vaak problemen op. Hoe verloopt de planning van de werkzaamheden voor de geïnterviewden?

Tabel 7.4: Verloop planning $(n=31)$

\begin{tabular}{llrr}
\hline & mannen & vrouwen & totaal \\
\cline { 2 - 4 } 1. moeizaam & $1(8 \%)$ & $1(6 \%)$ & $2(7 \%)$ \\
2. tamelijk moeizaam & $5(39 \%)$ & $5(28 \%)$ & $10(32 \%)$ \\
3. gemakkelijk/moeizaam & $2(15 \%)$ & $4(22 \%)$ & $6(19 \%)$ \\
4. tamelijk gemakkelijk & $3(23 \%)$ & $4(22 \%)$ & $7(23 \%)$ \\
5. gemakkelijk & $2(15 \%)$ & $4(22 \%)$ & $6(19 \%)$ \\
$\chi^{2}=.68, d f=4, \mathrm{n} . \mathrm{S}$. & & \\
\hline
\end{tabular}

Opvallend is dat bijna eenderde van de geïnterviewden aangeeft dat de planning tamelijk moeizaam verloopt. Enkelen geven aan de planning als moeizaam te ervaren. Ruim veertig procent geeft aan de planning van werkzaamheden gemakkelijk te vinden.

Om welke aspecten van planning gaat het zoal? De planning van de tijd wordt het meest genoemd. Vooral het inschatten van de tijdsduur die nodig is voor een bepaalde taak vindt men moeilijk. Daarnaast wordt vaker genoemd het stellen van prioriteiten. Ik moet keuzes maken wat ik eerst ga doen. Verder heeft men moeite met het strategisch plannen van activiteiten: Wanneer kan 
ik het beste de scholen bezoeken? Er is geen verschil in de planning van werkzaamheden door mannen en vrouwen.

In het vorige hoofdstuk over de eerste werkervaringen is de mate van tevredenheid over de verkregen feedback al aan de orde geweest. Hieronder volgt nogmaals de tabel over feedback.

Tabel 7.5: Tevredenheid over feedback $(n=30)$

\begin{tabular}{lllr}
\hline & mannen & vrouwen & totaal \\
\cline { 2 - 4 } 1. erg ontevreden & $2(13 \%)$ & $1 \quad(7 \%)$ & $3(10 \%)$ \\
2. tamelijk ontevreden & $4(29 \%)$ & $4(25 \%)$ & $8(27 \%)$ \\
3. gedeeltelijk ontevr/tevr & $5(35 \%)$ & $5(31 \%)$ & $10(33 \%)$ \\
4. tamelijk tevreden & $4(29 \%)$ & $5(31 \%)$ & $9(30 \%)$ \\
5. erg tevreden & - & - & - \\
$x^{2}=.31, \mathrm{df}=3$, n.s. & & \\
\end{tabular}

Slechts eenderde van de respondenten geeft aan tamelijk tevreden te zijn over de verkregen feedback. De grootste groep ( $36 \%$ ) geeft aan ontevreden te zijn. De onvrede werd veroorzaakt door de onbruikbaarheid van de feedback. De aanwijzingen die men kreeg waren zo algemeen dat men er niets aan had. Tevredenheid over feedback is meestal een gevolg van het verkrijgen van zinvolle aanwijzingen waarmee men het eigen functioneren kan verbeteren. Zowel mannen als vrouwen rapporteerden in gelijke mate hun onvrede over de feedback.

Samenvattend: Bijna veertig procent geeft aan problemen te hebben met betrekking tot de planning. Het gaat hierbij vooral om het plannen van de tijd die nodig is voor bepaalde taken en om het stellen van prioriteiten. Het merendeel van de geïnterviewden geeft aan ontevreden te zijn over de feedback die men krijgt.

\section{loopbaankenmerken}

Twee variabelen hebben betrekking op loopbaankenmerken. In hoeverre hecht men belang aan een beroepsloopbaan? Dit is de geïterviewden voorgelegd. Verondersteld werd dat er een samenhang is tussen het ervaren van succes en de mate waarin men een loopbaan belangrijk vindt. De resultaten staan beschreven in tabel 7.6. 


\begin{tabular}{llrr} 
& mannen & vrouwen & \multicolumn{1}{c}{ totaal } \\
\cline { 2 - 4 } 3. onbelangrijk/belangrijk & $4(27 \%)$ & $3(14 \%)$ & $7(19 \%)$ \\
4. tamelijk belangrijk & $6(40 \%)$ & $13(62 \%)$ & $19(53 \%)$ \\
5. erg belangrijk & $5(33 \%)$ & $5(24 \%)$ & $10(28 \%)$ \\
$\chi^{2}=1.77, \mathrm{df}=2$, n.s. & & & \\
\end{tabular}

Het blijkt dat ruim viervijfde van de geïnterviewden een beroepsloopbaan tamelijk belangrijk of erg belangrijk vindt. Niemand geeft aan een loopbaan onbelangrijk te vinden; de antwoordcategorieën 1 en 2 worden niet gebruikt. Eenvijfde van de respondenten geeft aan een loopbaan gedeeltelijk belangrijk, gedeeltelijk onbelangrijk te vinden. In de toelichting wordt het belang gerelativeerd: Tijdens mijn werk is het betrekkelijk geworden. Ik vind het belangrijk om werk te doen, dat ik prettig vind. Maar er zijn zoveel dingen die minstens zo belangrijk zijn.

Een van de variabelen met betrekking tot de loopbaankenmerken is de periode waarin men werkzaam is in de nieuwe baan. Het blijkt dat een kleine groep van $6 \%$ korter dan een half jaar werkt in de functie, $32 \%$ is gedurende 6 maanden tot een jaar werkzaam in de baan en het merendeel, namelijk $62 \%$, werkt langer dan een jaar in de huidige baan. Vrijwel iedereen voldoet daarmee aan het criterium dat men enige tijd werkzaam moet zijn in de functie voor het ervaren van succes.

Samenvattend: Viervijfde van de respondenten geeft aan een loopbaan tamelijk tot erg belangrijk te vinden. Bijna tweederde van de geïnterviewden werkt ruim een jaar in de functie.

\section{opleidingsaspecten}

Vooral in de eerste tijd in een baan kan de beschikbare kennis en vaardigheid houvast bieden. Gevraagd is naar de bruikbaarheid van de kennis en van de vaardigheden voor de baan. In hoeverre sluiten kennis en vaardigheden goed aan op de functie? In tabel 7.7 staat aangegeven welke mening de geïnterviewden hebben over de aansluiting van de kennis en van de vaardigheden. Tweederde van de geïnterviewden vindt de aansluiting tamelijk goed of goed. Een kwart van de werkenden noemt de aansluiting van de kennis op de baan gedeeltelijk goed. Voor $9 \%$ ontbreekt een goede aansluiting van de kennis die in de opleiding is verworven op datgene wat voor de functie wordt vereist. In hoeverre sluiten de vaardigheden goed aan die in de opleiding aan bod zijn geweest? Vergeleken met de aansluiting van de kennis is men het nu iets vaker volledig eens met de bewering dat de aansluiting van de vaardigheden op de functie goed is $(35 \%)$. Eenvierde geeft aan dat de aansluiting van de 
vaardigheden op de baan gedeeltelijk voldoet. Voor $12 \%$ ontbreekt een goede aansluiting van de geleerde vaardigheden op de eisen van de baan.

Tabel 7.7: Goede aansluiting kennis $(n=34)$ en vaardigheden $(n=34)$

\begin{tabular}{|c|c|c|c|c|c|c|}
\hline \multirow[b]{3}{*}{ 1. volledig oneens } & \multirow[b]{2}{*}{ mannen } & \multicolumn{2}{|l|}{ kennis } & \multirow[b]{2}{*}{ mannen } & \multicolumn{2}{|c|}{ vaardigheden } \\
\hline & & vrouwen & totaal & & vrouwen & totaal \\
\hline & $1 \quad(6 \%)$ & $(6 \%)$ & $(6 \%)$ & - & $1 \quad(6 \%)$ & $1 \quad(3 \%)$ \\
\hline 2. tamelijk oneens & - & $1(6 \%)$ & $1(3 \%)$ & $2(14 \%)$ & $1 \quad(6 \%)$ & $3(9 \%)$ \\
\hline 3. eens/oneens & $4(25 \%)$ & $4(22 \%)$ & $8(24 \%)$ & $3(20 \%)$ & $5(26 \%)$ & $8(24 \%)$ \\
\hline 4. tamelijk eens & $8(50 \%)$ & $7(39 \%)$ & $15(44 \%)$ & $5(33 \%)$ & $5(26 \%)$ & $10(29 \%)$ \\
\hline 5. volledig eens & $3(29 \%)$ & $5(28 \%)$ & $8(24 \%)$ & $5(33 \%)$ & $7(36 \%)$ & $12(35 \%)$ \\
\hline & \multicolumn{3}{|c|}{$x^{2}=1.45, d f=4$, n.s. } & \multicolumn{3}{|c|}{$x^{2}=1.72, d f=4$, n.s. } \\
\hline
\end{tabular}

Samenvattend kunnen we stellen dat ongeveer tweederde van de geïnterviewden vindt dat de kennis opgedaan tijdens de opleiding goed aansluit op de functie. Eveneens tweederde geeft aan dat de geleerde vaardigheden goed aansluiten.

In het volgende hoofdstuk wordt verder ingegaan op de rol van de opleiding voor het functioneren in de werksituatie.

\section{Relaties tussen functiekenmerken, zelfmanagement, loopbaan- kenmerken, opleidingsaspecten en het ervaren van succes}

In de vierde fase van de overgang van de opleiding naar de arbeidsmarkt zijn de onafhankelijke variabelen geclusterd rond een viertal thema's: functiekenmerken, zelfmanagement, loopbaankenmerken en opleidingsaspecten. Allereerst wordt de correlatiematrix van de onafhankelijke variabelen in deze fase besproken. Daarna wordt ingegaan op de correlaties tussen de onafhankelijke variabelen en het ervaren van succes.

Uit de correlatiematrix in tabel 7.8 blijkt dat er een samenhang is tussen de aard van de functie en de aansluiting van de kennis die tijdens de opleiding is geleerd op de baan. Voor de meer specialistische functies is de aansluiting van de kennis beter dan voor de meer generalistische functies. Dit kan verband houden met het feit dat duidelijker is welke kennis is vereist voor meer specialistische functies. Waarschijnlijk zijn de respondenten op basis van deze kennis geselecteerd voor de functie (Kluytmans, 1993).

De ervaringen met het plannen van de werkzaamheden houden verband met de mate waarin men tevreden is over de aansluiting van de vaardigheden die 
tijdens de opleiding zijn geleerd. Hoe gemakkelijker men in staat is de werkzaamheden te plannen, des te positiever is men over de aansluiting van de geleerde vaardigheden. Mogelijk zijn de geleerde vaardigheden een hulpmiddel voor het plannen van de werkzaamheden.

Er blijkt een samenhang te zijn tussen de verkregen feedback en het belang dat men hecht aan de loopbaan. Hoe meer men tevreden is over de feedback, des te belangrijker vindt men een toekomstige loopbaan. Door het krijgen van goede feedback raakt men mogelijk meer betrokken bij het werk waardoor men ook meer gemotiveerd wordt voor een toekomstige loopbaan. Dit wordt eveneens door Hall (1976) aangegeven in de succescyclus. De periode waarin men werkzaam is, hangt samen met het oordeel over de aansluiting van de geleerde vaardigheden. Met name in de allereerste beginperiode geeft men aan dat de aansluiting van de vaardigheden goed is. Mogelijk geven de vaardigheden waarover men beschikt houvast in de eerste periode in de nieuwe baan. De geleerde vaardigheden vormen waarschijnlijk een concreet instrument om een bijdrage te kunnen leveren in het werk. Dit werd in het vorige hoofdstuk ook genoemd als belangrijke positieve ervaring.

Tabel 7.8: Correlatiematrix van de fase van succes ervaren $(28 \leq n \leq 37)^{4}$

\begin{tabular}{|c|c|c|c|c|c|c|c|c|c|}
\hline & 1 & 2 & 3 & 4 & 5 & 6 & 7 & 8 & 9 \\
\hline 1. specialisatie & 1.00 & .00 & .11 & .19 & .12 & -.02 & $-.50^{\circ}$ & -.02 & .04 \\
\hline 2. autonomie & & 1.00 & -.07 & -.05 & .20 & .02 & .06 & .20 & -.20 \\
\hline 3. planning & & & 1.00 & .07 & -.18 & -.24 & .22 & $.33^{\circ}$ & .11 \\
\hline 4. feedback & & & & 1.00 & $.48^{\circ}$ &. .13 & -.09 & -.09 & -.02 \\
\hline 5. belang loopbaan & & & & & 1.00 & -.12 & .23 & .05 & .02 \\
\hline 6. periode werkzaam & & & & & & 1.00 & -.20 & $-.36^{\circ}$ & .19 \\
\hline 7. kennis & & & & & & & 1.00 & .08 & .01 \\
\hline 8. vaardigheden & & & & & & & & 1.00 & -.01 \\
\hline 9. geslacht & & & & & & & & & 1.00 \\
\hline
\end{tabular}

In tabel 7.9 zijn de correlaties met het ervaren van succes weergegeven. Hieruit blijkt dat er een samenhang is tussen de mate van autonomie in de functie en het ervaren van succes. Hoe meer men tevreden is over de autonomie in de functie, des te meer ervaart men succes. Een optimale mate van autonomie draagt blijkbaar bij aan een positieve beoordeling van de eigen werkzaamheden.

\footnotetext{
${ }^{4}$ De exacte waarde van $n$ per cel van de correlatiematrix staat vermeld in tabel 4 in de bijlage.
} 
Het gemak waarmee men de werkzaamheden kan plannen hangt in sterkere mate samen met het ervaren van succes. Verder blijkt er een samenhang te zijn tussen het ervaren van succes en de bruikbaarheid van de geleerde vaardigheden. Naarmate de geleerde vaardigheden in de baan kunnen worden toegepast, ervaart men meer succes.

Tabel 7.9: Correlaties met succes

$\begin{array}{lll}\text { 1. specialisatie } & .00 & (n=33) \\ \text { 2. autonomie } & .33^{\circ} & (n=33) \\ \text { 3. planning } & .47^{\circ} & (n=28) \\ \text { 4. feedback } & .06 & (n=26) \\ \text { 5. belang loopbaan } & -.04 & (n=32) \\ \text { 6. periode werkzaam } & -.18 & (n=33) \\ \text { 7. kennis } & .19 & (n=30) \\ \text { 8. vaardigheden } & .39^{\circ} & (n=30) \\ \text { 9. geslacht } & . .03 & (n=33)\end{array}$

$(* p \leq .05, * * p \leq .01, * * p \leq .001)$

\section{Causale modellering van de fase van het ervaren van succes}

Ook voor de fase van het ervaren van succes, hebben we de gevonden verbanden tussen variabelen onderworpen aan SEM, het modelleren van structurele vergelijkingen (Bentler, 1995). Voor een korte uitleg van de aard van de betreffende techniek wordt verwezen naar hoofdstuk 4 . Hier wordt volstaan met de constatering dat de onderhavige analyses vooral als exploratief moeten worden geduid. Aan de uitkomsten mag dan ook slechts beperkte betekenis worden gehecht.

\section{methode}

De data werden geanalyseerd met behulp van EOS (Bentler, 1995).

\section{resultaten}

In figuur 10 zijn de resultaten van de analyses op grafische wijze weergegeven. Het gepresenteerde model past goed: Chi-kwadraat $=3,50$, df $=5, p$ $=0.62 ; \mathrm{CFI}=1.00$. 


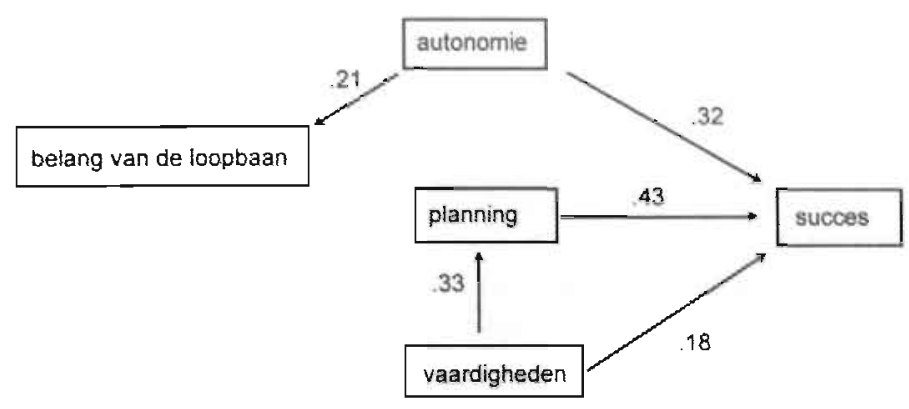

chi-kwadraat $=3.50$, d.f. $=5, p=0.62$

$\mathrm{CFI}=\uparrow .00$

Figuur 10: De fase van succes ervaren

Uit de figuur valt af te leiden dat de planning van de werkzaamheden positief en in sterke mate (.43) van invloed zijn op het ervaren van succes. De mate van autonomie in het werk is eveneens sterk van invloed op het ervaren van succes, de padcoëfficiënt bedraagt .32. De relevantie van de vaardigheden voor de functie is eveneens positief van invloed op het ervaren van succes; zij het in iets zwakkere mate: .18. Verder wordt een sterke positieve invloed van .33 geconstateerd van de relevantie van de vaardigheden op de planning van de werkzaamheden. De mate van autonomie die men ervaart in het werk is positief ter grootte van .21 van invloed op het belang dat men hecht aan de loopbaan.

\section{Discussie}

In dit hoofdstuk is de fase van het ervaren van succes besproken. Wat zijn de meest opvallende bevindingen in deze fase van het overgangsproces van de opleiding naar de arbeidsmarkt?

In het verklaringsmodel komen enkele variabelen naar voren als determinanten van succes. Het gaat om de mate van autonomie in het werk, de planning van werkzaamheden, en de bruikbaarheid van de geleerde vaardigheden. De bruikbaarheid van de vaardigheden is ook indirect van invloed op het ervaren van succes via de planning van de werkzaamheden.

In deze fase gaat het niet in de eerste plaats om de functie maar vooral om de capaciteiten van de betrokkenen. Essentieel is in hoeverre de persoon in staat is de taken op autonome wijze planmatig uit te voeren, gebruik makend van de vaardigheden waarover hij of zij beschikt.

De eerste elementen uit de succescyclus van Hall (1976) zien we terug in het verklaringsmodel. Succes in de carrière verloopt volgens Hall in cycli. Allereerst wordt een bepaald werkdoel gekozen en vervolgens een werkwijze om dat doel aan te pakken. In staat zijn prioriteiten te stellen en een goede planning te maken, zijn hiervoor noodzakelijk. Door middel van onafhankelijk 
werken wordt een bepaald prestatieniveau bereikt. Voor het onafhankelijk kunnen werken aan een taak is autonomie in het werk vereist. Vaardigheden zijn van belang bij het uitoefenen van de taak. Onder deze condities kan een bepaalde mate van psychologisch succes in het werk worden ervaren. De elementen van job-satisfactie, job-involvement en motivatie uit de cyclus, zouden kunnen worden vertegenwoordigd door het belang van de loopbaan. In het verklaringsmodel wordt het belang van de loopbaan bepaald door de autonomie in het werk. Zelfstandig kunnen werken verhoogt niet alleen de betrokkenheid bij het werk maar ook de betrokkenheid bij en motivatie voor een verdere loopbaan.

De elementen uit de cyclus komen overeen maar de relaties worden in het verklaringsmodel anders aangegeven, namelijk niet indirect: dat doelgerichtheid via autonomie van invloed is op het bereiken van prestaties, waardoor succes wordt ervaren. Uit het verklaringsmodel blijkt dat zowel autonomie, als planning en vaardigheden alle direct van invloed zijn op succes.

Functiekenmerken zijn niet van invloed; het maakt geen verschil of de functie voornamelijk specialistisch is of generalistisch. Ook de kennis die in de opleiding is geleerd komt niet terug in het verklaringsmodel voor het ervaren van succes. Er zijn nauwelijks verschillen tussen mannen en vrouwen in deze fase van succes ervaren. Vrouwen zijn iets meer ontevreden over de mate van autonomie in de baan. 


\section{De aansluiting van opleiding op werksituatie}

In dit hoofdstuk worden de resultaten besproken die betrekking hebben op de aansluiting van de opleiding op de beroepspraktijk. Het vierde deelonderzoek is gericht op een vergelijking van de kwaliteiten van studenten die probleemgestuurd onderwijs volgen met studenten die een meer traditioneel opgezet curriculum volgen. Daarnaast wordt ingegaan op het belang van de opleiding voor de beroepspraktijk zoals gerapporteerd door de respondenten in de verschillende metingen. Verder wordt de discrepantie besproken tussen de verwachte relevantie van opleidingsaspecten en de feitelijke relevantie zoals die in de werksituatie wordt waargenomen. Verschillen tussen mannen en vrouwen worden eveneens bekeken.

De aansluiting tussen de opleiding en de beroepspraktijk kan worden bekeken vanuit het perspectief van de opleiding maar ook vanuit het perspectief van de arbeidsorganisatie. Vanuit welke visie worden studenten opgeleid? En wat wordt verwacht van medewerkers in een organisatie? Over welke kennis en vaardigheden moeten zij kunnen beschikken? Allereerst wordt ingegaan op het opleidingsperspectief.

\section{probleemgestuurd onderwijs}

Verondersteld mag worden dat probleemgestuurd onderwijs positief bijdraagt aan de overgang naar de arbeidsmarkt. Immers tijdens de opleiding wordt gewerkt met casuistiek die ontleend is aan de beroepspraktijk. Studenten krijgen problemen voorgelegd tijdens de studie die vergelijkbaar zijn met de vraagstukken die zij na afstuderen in hun werk moeten aanpakken. Tijdens de studie leert men een methodiek van probleemoplossen die in de beroepspraktijk eveneens van belang is. Toch is in de literatuur over probleemgestuurd leren weinig terug te vinden over de aansluiting op de beroepspraktijk.

Schmidt (1993) noemt een aantal cognitieve effecten op het leren van studenten door middel van PGO: Activatie van voorkennis; uitbreiden van de kennis door middel van discussie; actieve verwerving van nieuwe informatie; herstructureren van de kennis afhankelijk van de probleemstelling; leren in een context, waardoor vergelijkbare problemen kunnen worden opgelost; de motivatie en nieuwsgierigheid voor het vakgebied zal worden vergroot door de relevantie van de problemen. Met name 'leren in een context' kan worden gezien als van belang voor de overgang naar de arbeidsmarkt. De bruikbaar- 
heid van de kennis wordt bij PGO ais het ware meteen duidelijk; bepaalde problemen kunnen ermee worden opgelost. Het gaat dan om de casuïstiek in de leersituatie maar ook om vergelijkbare casus in de beroepspraktijk. Het vergroten van de motivatie voor het vakgebied is eveneens relevant voor het overgangsproces naar de arbeidsmarkt.

Drop en Post (1990) presenteren een studie naar de beoordeling van het PGOcurriculum door afgestudeerden en medewerkers. Gesteld wordt dat een van de belangrijkste doelen van de onderwijskundige vernieuwing in Maastricht was om mensen op te leiden die in staat zijn samen te werken met andere professionals in de gezondheidszorg en die zich onderscheiden door probleemoplossende kwaliteiten en het vermogen om zelfgestuurd en continu te leren. Dit verwijst naar een bepaalde wijze van functioneren in de beroepspraktijk, namelijk dat professionals in staat zijn effectief samen te werken met andere disciplines en in staat zijn nieuwe problemen op te lossen.

Zij hebben gevraagd naar de realisatie en waardering van verschillende kenmerken van het PGO-curriculum. Als sterke kanten van het curriculum worden beschouwd: vaardigheidsonderwijs, onderwijsgroepen, werken in de huisartsenpraktijk, probleemoriëntatie, self-directed learning en de diversiteit van het onderwijsmateriaal.

\section{de lerende organisatie}

De visie op leren in PGO-onderwijs heeft overeenkomsten met de uitgangspunten van de lerende organisatie. Swieringa en Wierdsma (1990) stellen dat in opleidingen vrijwel alle nadruk ligt op het overdragen van kennis en inzicht, terwijl aan het ontwikkelen van bekwaamheid weinig aandacht wordt besteed. Bekwaamheid wordt volgens hen niet alleen bepaald door wat iemand weet en begrijpt, maar ook door wat hij of zij kan, durft en wil en ook door wie hij of zij is. Leren moet dan ook niet alleen gericht zijn op het verwerven van kennis, maar ook op het ontwikkelen van vaardigheden en van de persoonlijkheid. Pas dan zijn individuen in staat om zich in de werksituatie verder te ontwikkelen. Dit heeft effect op de samenwerking met collega's en uiteindelijk ook op de organisatie. Het is een noodzakelijke voorwaarde voor de organisatie zich verder te ontwikkelen, om uiteindelijk collectief leren te bevorderen. Voor organisaties is het van belang dat zij zich kunnen aanpassen aan veranderde omstandigheden, dat zij flexibel kunnen inspelen op nieuwe eisen van de omgeving. Het begrip lerende organisatie geeft aan dat de organisatie in staat is leren te leren, om continu en zelfgestuurd te leren.

De basis voor deze visie is te vinden in het leermodel van Kolb (1984), waarin het verwerven van kennis en inzicht is geïntegreerd in het ontwikkelen van vaardigheden en houding. Kolb spreekt ook van probleemgericht leren. In het model van Kolb kunnen dagelijkse handelingsprocessen onderdeel zijn van leerprocessen. Door bewust te reflecteren op deze dagelijkse processen kan leren plaats vinden.

Swieringa en Wierdsma (1990) beschouwen leren op een vergelijkbare wijze in hun benadering van de lerende organisatie. Want, zo stellen zij, ook bij 
organisatiegedrag wordt de stimulans en het medium van leren gevormd door problemen. Een lerende organisatie leert probleemgericht, dat wil zeggen: leerprocessen worden gestuurd door problemen. Probleemgericht leren in organisaties houdt in dat leren gekoppeld is aan het werk. De werkplek wordt. gezien als leersituatie. In een lerende organisatie wordt denken en doen niet gescheiden maar gekoppeld via bezinnen en beslissen. Weergegeven door de cyclus: doen - bezinnen - denken - beslissen.

Wat leren studenten tijdens de opleiding en in hoeverre is dit relevant voor de werksituatie? Allereerst worden discrepanties besproken tussen de verwachte relevantie van onderdelen uit de opleiding en de feitelijke relevantie van deze onderdelen zoals die in de werksituatie blijken. Daarna wordt een studie gepresenteerd waarbij studenten van een opleiding waarin gewerkt wordt met probleemgestuurd onderwijs, worden vergeleken met studenten die een traditioneel curriculum volgen. Zijn er discrepanties tussen de kwaliteiten waarover beide groepen beschikken en in hoeverre heeft de opleiding hieraan bijgedragen?

\section{Verwachte en feitelijke relevantie van de opleiding}

Om inzicht te krijgen in de aansluiting van de opleiding op de werksituatie zijn enkele vragen opgenomen in de vragenlijst voor studenten en enkele vragen gesteld tijdens de interviews met werkenden. Aan studenten is gevraagd aan te geven wat de relevantie is van de kennis en vaardigheden die in de studie zijn geleerd, voor de toekomstige beroepspraktijk. In de interviews met werkenden is gevraagd in hoeverre de opleiding feitelijk aansluit op hun huidige functie.

In de volgende tabellen wordt de verwachte aansluiting van de kennis (tabel 8.1) en de feitelijke aansluiting van de kennis op de beroepspraktijk (tabel 8.2) aangegeven.

Tabel 8.1: Verwachte aansluiting van de kennis $(n=177)$

\begin{tabular}{lrrr}
\hline & mannen & vrouwen & totaal \\
\cline { 2 - 4 } & $1(2 \%)$ & $6(5 \%)$ & $7(4 \%)$ \\
1. erg slecht & $9(21 \%)$ & $15(11 \%)$ & $24(14 \%)$ \\
2. tamelijk slecht & $5(11 \%)$ & $24(18 \%)$ & $29(16 \%)$ \\
3. ged. goed/slecht & $23(52 \%)$ & $78(58 \%)$ & $101(57 \%)$ \\
4. tamelijk goed & $6(14 \%)$ & $10(8 \%)$ & $16(9 \%)$ \\
5. erg goed & & & \\
$x^{2}=4,97, \mathrm{df}=4$, n.s. & & \\
\hline
\end{tabular}




\begin{tabular}{lcrr}
\hline & & & \\
& mannen & vrouwen & totaal \\
\cline { 2 - 4 } 1. erg slecht & $1(6 \%)$ & $1(6 \%)$ & $2(6 \%)$ \\
2. tamelijk slecht & - & $1(6 \%)$ & $1(3 \%)$ \\
3. ged. goed/slecht & $4(25 \%)$ & $4(22 \%)$ & $8(24 \%)$ \\
4. tamelijk goed & $8(50 \%)$ & $7(39 \%)$ & $15(44 \%)$ \\
5. erg goed & $3(19 \%)$ & $5(28 \%)$ & $8(24 \%)$ \\
$x^{2}=1.45, \mathrm{df}=4$, n.s. & & & \\
\end{tabular}

De feitelijke aansluiting van de kennis lijkt naar verhouding iets beter dan de verwachte aansluiting. De verschillen zijn echter klein. Van de werkenden geeft eenvierde aan dat de kennis goed aansluit op de functie. Voor ruim $40 \%$ procent sluit de kennis tamelijk goed aan op de functie. Van de studenten koos ruim de helft voor deze categorie. Bijna eenvijfde van de studenten verwachtte dat de kennis niet goed zou aansluiten op de toekomstige functie; van degenen met een baan geeft slechts $9 \%$ aan dat de kennis niet goed aansluit.

Hoe ziet men de aansluiting van de geleerde vaardigheden op de toekomstige functie? En hoe beoordelen werkenden de feitelijke aansluiting van de vaardigheden? Zie hiervoor tabel 8.3 en 8.4.

Tabel 8.3: Verwachte aansluiting vaardigheden $(n=174)$

\begin{tabular}{lrrr}
\hline & mannen & vrouwen & totaal \\
\cline { 2 - 4 } & $2(5 \%)$ & $2(2 \%)$ & $4(2 \%)$ \\
1. erg slecht & $8(19 \%)$ & $8(6 \%)$ & $16(9 \%)$ \\
2. tamelijk slecht & $8(19 \%)$ & $18(13 \%)$ & $26(15 \%)$ \\
3. gedeeltelijk goed/slecht & $20(48 \%)$ & $70(53 \%)$ & $90(52 \%)$ \\
4. tamelijk goed & $4(9 \%)$ & $34(26 \%)$ & $38(22 \%)$ \\
5. erg goed & & & \\
$x^{2}=11,95, \mathrm{df}=4, \mathrm{p}<.05$ & & & \\
\hline
\end{tabular}

De helft van de studenten verwacht dat de vaardigheden tamelijk goed aansluiten op de functie. Eenvijfde verwacht dat de aansluiting erg goed zal zijn. Bij de verdeling voor de feitelijke aansluiting zien we dat ruim eenderde vindt dat de aansluiting erg goed is en eenderde geeft aan dat de vaardigheden tamelijk goed aansluiten. Mannen en vrouwen verschillen in hun verwachting ten aanzien van de bruikbaarheid van de vaardigheden. Vrouwen zijn hierover 
meer positief. In de feitelijke aansluiting van de vaardigheden zijn geen verschillen tussen mannen en vrouwen.

Tabel 8.4: Feitelijke aansluiting van vaardigheden $(n=34)$

\begin{tabular}{lcrr}
\hline & mannen & vrouwen & totaal \\
\cline { 2 - 4 } & & 1 & $(5 \%)$ \\
1. erg slecht & $2(14 \%)$ & $1(5 \%)$ & $3(3 \%)$ \\
2. tamelijk slecht & $3(20 \%)$ & $5(26 \%)$ & $8(24 \%)$ \\
3. gedeeltelijk goed/slecht & $5(33 \%)$ & $5(26 \%)$ & $10(29 \%)$ \\
4. tamelijk goed & $5(33 \%)$ & $7(38 \%)$ & $12(35 \%)$ \\
5. erg goed & & & \\
$x^{2}=1,71, \mathrm{df}=4$, n.s. & & \\
\hline
\end{tabular}

Wat zien studenten als relevante vaardigheden voor hun toekomstige beroepsuitoefening? Hiervoor zijn 24 vaardigheden voorgelegd, waarvan men kon aangeven of deze vaardigheden niet of nauwelijks relevant (1) zouden zijn, enigszins relevant (2) of in sterke mate relevant (3). De meest relevant verwachte vaardigheden staan beschreven in de volgende tabel.

Tabel 8.5: Meest relevante vaardigheden $(n=175)$

\begin{tabular}{|c|c|c|}
\hline & gem. & s.d. \\
\hline 1. probleemoplossen & 2.9 & .3 \\
\hline 2. schriftelijk rapporteren & 2.9 & .3 \\
\hline 3. mondeling rapporteren & 2.8 & .4 \\
\hline 4. groepsgesprekken/vergadertechniek & 2.8 & .4 \\
\hline 5. onderhandelen & 2.4 & .8 \\
\hline 6. management vaardigheden & 2.3 & .8 \\
\hline 7. statistische en computervaardigheden & 2.3 & .7 \\
\hline
\end{tabular}

Probleemoplossen, schriftelijke en mondeling rapporteren en groepsgesprekken of vergadertechniek ziet men als het meest belangrijk voor de beroepspraktijk. De scores op deze vaardigheden waren erg hoog: 2.9 en 2.8 bij een maximum van 3.0. Al deze vaardigheden maken onderdeel uit van probleemgestuurd onderwijs.

Ook afgestudeerden geven aan dat de vaardigheden die zijn verworven door middel van PGO bruikbaar zijn voor hun huidige baan. In de volgende para- 
graaf staat beschreven welke kwaliteiten met in het PGO-onderwijs heeft verworven.

\section{samenvatting}

De feitelijke aansluiting van de kennis op de functie is iets positiever dan werd verwacht. Dit hangt mogelijk samen met de onzekerheid van studenten over de hoeveelheid kennis die zij in de studie verwerven. In de praktijk blijkt de kennis dan toereikend voor de taken die men moet vervullen of men blijkt goed in staat te zijn om leemtes in de kennis aan te vullen. De feitelijke aansluiting van de vaardigheden komt overeen met de verwachtingen. De transfer van de geleerde vaardigheden naar de beroepspraktijk is hoog. Probleemoplossen, schriftelijke en mondeling presenteren en groepsgesprekken ziet men als de meest relevante vaardigheden. Dit zijn vaardigheden die inherent zijn aan het probleemgestuurd onderwijs.

\section{Vergelijking tussen studenten in een PGO-curriculum en een traditioneel curriculum}

Om inzicht te krijgen in de persoonlijke kwaliteiten van studenten en de relatie met het gevolgde onderwijs werd de vragenlijst Persoonlijke kwaliteiten afgenomen bij zowel studenten die een PGO-curriculum volgden als bij studenten die een meer traditioneel onderwijssysteem hebben gevolgd. Het gaat hierbij om een vergelijking tussen de groep die een PGO-curriculum volgt én de groep studenten die een traditioneel curriculum volgt. Zijn er verschillen tussen de twee groepen wat betreft de vaardigheden en kwaliteiten waarover zij beschikken en wat betreft hun visie op de bijdrage van onderwijs hieraan? De resultaten worden bekeken op item niveau en op de vier gebieden planmatig gedrag, probleemoplossen, groepsdynamica en leidinggeven; verder zijn de open vragen vergeleken.

\section{steekproef}

De groep PGO-studenten bestond uit 181 personen, waarvan 46 mannen en 135 vrouwen. Bijna tweederde van de respondenten zat in het vierde jaar van de studie. Eenvierde deel van de studenten was vijfdejaars. De verdeling over studiejaren is weergegeven in tabel 8.6.

De vragenlijst Persoonlijke kwaliteiten en onderwijs werd afgenomen bij een groep studenten die een opleiding volgde met een meer traditioneel opgezet curriculum. Deze groep bestond uit 31 studenten, waarvan bijna de helft in het derde jaar van de studie was. Een groep van $45 \%$ was vierdejaars of ouder.

De verhouding mannen en vrouwen in de traditionele groep bedroeg $1: 3$. In tabel 8.7 is de verdeling over de studiejaren van de traditionele groep weergegeven. 


\begin{tabular}{lrr}
\hline & frequentie & percentage \\
\cline { 2 - 3 } vierde jaars & 116 & 64 \\
vijfdejaars & 48 & 27 \\
zesdejaars & 15 & 8 \\
zevendejaars & 2 & 1 \\
totaal & 181 & 100 \\
\hline
\end{tabular}

Tabel 8.7: Studiejaar van de traditionele groep $(n=31)$

\begin{tabular}{lcc} 
& frequentie & percentage \\
\cline { 2 - 3 } & 14 & 45 \\
derdejaars & 12 & 39 \\
vierdejaars & 1 & 3 \\
vijfdejaars & 1 & 3 \\
zesdejaars & 3 & 10 \\
onbekend & 181 & 100 \\
totaal & & \\
\hline
\end{tabular}

De gemiddelde leeftijd van de PGO-groep bedroeg 26 jaar; de studenten uit de traditionele groep waren gemiddeld 25 jaar oud.

In de traditionele groep had $23 \%$ een vooropleiding gevolgd; van de PGOgroep had $17 \%$ een vooropleiding voltooid.

De steekproef van de traditionele groep beperkt zich tot 31 studenten. De verhouding mannen en vrouwen is gelijk voor de traditionele groep en de PGO-groep. De PGO-groep is verder gevorderd in de studie. Het merendeel van de studenten is vierdejaars. De PGO-groep is gemiddeld één jaar ouder dan de traditionele groep. De traditionele groep heeft daarentegen vaker een vooropleiding gevolgd; $23 \%$ tegen $17 \%$ van de PGO-groep.

\section{onderzoeksinstrument}

De vragenlijst Persoonlijke kwaliteiten en PGO is afgenomen bij de respondenten in het tweede deelonderzoek. Deze vragenlijst bestaat uit 46 beweringen waarin een bepaalde vaardigheid of kwaliteit wordt beschreven. Van elke bewering werd aan de respondent gevraagd aan te geven in hoeverre hij of zij beschikte over de betreffende kwaliteit en welke bijdrage de opleiding heeft gehad aan het verwerven van deze vaardigheid of kwaliteit. 
Op basis van factoranalyse zijn vier gebieden onderscheiden in de vragenlijst: 1. planmatig gedrag, 2. probleemoplossend vermogen, 3 . groepsdynamische vaardigheden en 4 . leidinggevende kwaliteiten.

Het cluster planmatig gedrag bestaat uit 10 items die alle verwijzen naar een planmatige en doelgerichte werkstijl. Personen die in hoge mate planmatig gedrag vertonen zijn eveneens in staat zich flexibel aan te passen aan veranderde omstandigheden.

Het cluster probleemoplossen bestaat uit 12 items. De vragen hebben betrekking op probleemoplossend vermogen, inschatting van eigen mogelijkheden en gebruik kunnen maken van de juiste bronnen.

Het cluster groepsdynamische vaardigheden bestaat uit 10 items die betrekking hebben op samenwerking en conflicthantering in een groep.

Het cluster leidinggeven bestaat uit 7 items en heeft betrekking op het nemen van initiatieven en verantwoordelijkheid in een groep.

Van de vragenlijst is een meer algemene versie gemaakt, waarbij niet specifiek werd gevraagd naar de bijdrage van PGO maar naar de bijdrage van onderwijs: Persoonlijke kwaliteiten en onderwijs. Deze versie is afgenomen bij een groep ouderejaars studenten van een andere universiteit.

Met behulp van T-testen zijn de twee groepen vergeleken wat betreft hun antwoorden op de verschillende items.

\section{resultaten}

Uit de vergelijkingen op item niveau blijkt een significant verschil op 8 vragen met betrekking tot de mate waarin men beschikt over bepaalde vaardigheden of kwaliteiten. Bij 6 vragen scoort de PGO-groep hoger dan de traditionele groep; bij 2 vragen scoort de traditionele groep hoger dan de PGO-groep. (Zie tabel 8.8 en 8.9 ). De scores lopen van 1 tot 5 , waarbij 1 wil zeggen dat men het volledig oneens is met de bewering, en 5 betekent dat men het volledig eens is met de bewering.

Bij de respondenten uit het PGO-curriculum zien we dat met name vaardigheden worden genoemd die kenmerkend zijn voor PGO, zoals problemen kunnen analyseren, regelmatig werken, verschillende vakgebieden kunnen integreren en samenwerking met andere disciplines. Op deze vaardigheden verschillen zij significant van de groep die het traditionele curriculum volgt.

Studenten uit het traditionele curriculum geven aan dat zij met name sterk zijn in zelfbeoordeling. Zij geven aan dat zij een goed inzicht hebben in eigen sterke en zwakke kanten en dat zij hun eigen prestaties goed kunnen inschatten. 


\begin{tabular}{|c|c|c|c|c|}
\hline & \multirow{2}{*}{$\frac{\text { PGO }}{\text { gem. }}$} & \multirow[b]{2}{*}{ s.d. } & \multicolumn{2}{|c|}{ traditioneel } \\
\hline & & & gem. & s.d. \\
\hline 1. samenwerken met andere disciplines & 4.3 & $.6(n=163)$ & 3.9 & $.7(n=31)^{\cdots}$ \\
\hline 2. problemen analyseren & 4.2 & $.6(n=180)$ & 3.9 & $6(n=31)^{\circ}$ \\
\hline 3. regelmatig werken & 3.9 & $9(n=180)$ & 3.5 & $.10(n=31)^{\circ}$ \\
\hline 4. verschillende vakgebieden integreren & 3.9 & $.7(n=164)$ & 3.6 & $.8(n=31)^{\circ}$ \\
\hline 5. opsporen van informatiebronnen & 3.8 & $.7(n=180)$ & 3.5 & $.9(n=31)^{\circ}$ \\
\hline 6. voorzitten van een vergadering & 3.8 & $.6(n=180)$ & 3.5 & $.7(n=30)^{\circ}$ \\
\hline
\end{tabular}

Tabel 8.9: Kwaliteiten traditionele groep

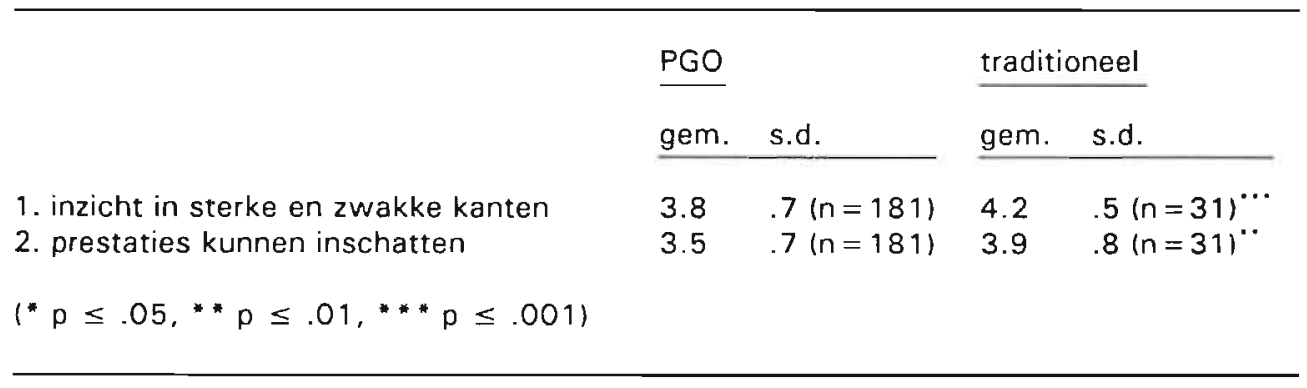

Een tweede vraag die per bewering moest worden beantwoord, heeft betrekking op de bijdrage van het gevolgde onderwijs aan het verwerven van de vaardigheid of kwaliteit. Bij 21 items is er een significant verschil gevonden tussen de mate waarin het onderwijs heeft bijgedragen aan de betreffende kwaliteiten volgens de respondenten. In 19 gevallen gaat het om een hogere bijdrage van PGO; in 2 gevallen gaat het om een hogere bijdrage van het traditionele onderwijs. In tabel 8.10 en 8.11 zijn de items opgenomen waarbij de gemiddelde score hoger is dan drie. De scores lopen van 1 tot 5 , waarbij 1 wil zeggen dat het gevolgde onderwijs absoluut niet heeft bijgedragen, en 5 wil zeggen dat het onderwijs zeer veel heeft bijgedragen. De score 3 geeft aan dat onderwijs enigszins heeft bijgedragen aan het verwerven van de kwaliteit. 


\begin{tabular}{|c|c|c|c|c|}
\hline & \multirow{2}{*}{$\frac{\text { PGO }}{\text { gem. }}$} & \multirow[b]{2}{*}{ s.d. } & \multicolumn{2}{|c|}{ traditioneel } \\
\hline & & & gem. & s.d. \\
\hline 1. voorzitten van een vergadering & 4.0 & $.7(n=181)$ & 3.0 & $1.1(n=31)^{\cdots}$ \\
\hline 2. opsporen van informatiebronnen & 3.8 & $1.0(n=164)$ & 3.4 & $1.0(n=31)^{\circ}$ \\
\hline 3. leiding geven in een groep & 3.5 & $.8(n=181)$ & 2.7 & $1.0(n=31)^{\cdots}$ \\
\hline 4. mening naar voren brengen & 3.5 & $.9(n=181)$ & 2.8 & $1.1(n=31)^{\cdots}$ \\
\hline 5. taken verdelen & 3.4 & $.8(n=181)$ & 2.6 & $1.0(n=31)^{\cdots}$ \\
\hline 6. mening formuleren & 3.3 & $.8(n=181)$ & 2.8 & $.9(n=31)^{\cdots}$ \\
\hline 7. doelgericht werken & 3.3 & $1.0(n=179)$ & 2.6 & $1.0(n=-30)^{\cdots}$ \\
\hline 8. samenwerken met andere disciplines & 3.3 & $1.1(n=162)$ & 2.7 & $1.1(n=30)^{\prime}$ \\
\hline 9. moeilijk onderwerp uitleggen & 3.2 & $.9(n=181)$ & 2.6 & $.8(n=31)^{\cdots}$ \\
\hline 10. planmatig werken & 3.2 & $1.1(n=181)$ & 2.7 & $1.2(n=30)^{\circ}$ \\
\hline 11. advies vragen & 3.2 & $1.0(n=164)$ & 2.8 & $1.0(n=30)^{\circ}$ \\
\hline 12. omgaan met conflictsituaties & 3.2 & $.9(n=181)$ & 2.8 & $1.0(n=31)^{\circ}$ \\
\hline$(* p \leq .05, * * \leq \leq .01, * * p \leq .001)$ & & & & \\
\hline
\end{tabular}

Studenten die het PGO-curriculum volgen, geven aan dat het gevolgde onderwijs een hogere bijdrage heeft geleverd aan de verworven vaardigheden en kwaliteiten dan de studenten die een traditioneel curriculum volgen. Bij een groot aantal items ligt de gemiddelde score hoger.

Tabel 8.11: Hogere bijdrage van traditioneel onderwijs

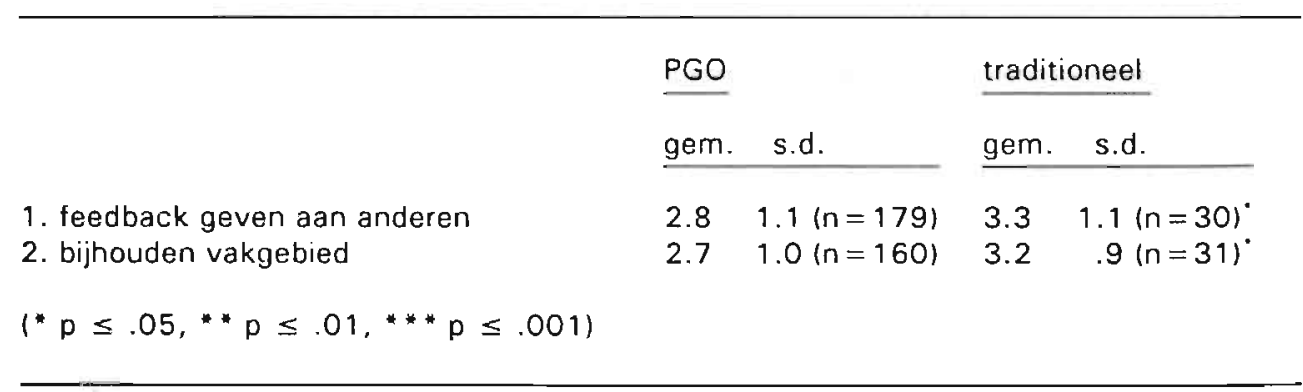

Op basis van de vergelijking van de groepen op de vier clusters blijken de studenten te verschillen op twee gebieden, namelijk met betrekking tot planmatig gedrag en leidinggeven. Zie tabel 8.12. 
PGO

gem. s.d.

1. planmatig gedrag

2. probleemoplossen

3. groepsdynamica

4. leidinggeven

$\begin{array}{ll}4.0 & .5(n=162) \\ 3.7 & .4(n=150) \\ 3.6 & .4(n=165) \\ 3.8 & .4(n=177)\end{array}$

$4.0 \quad .5(n=162)$

$.4(n=177)$ traditioneel

gem. s.d.

$3.8 \quad .5(n=30)^{-}$

$3.7 \quad .5(n=31)$ n.s.

$3.7 .4(n=31) n .8$.

$3.7 \quad .5(n=30)^{\circ}$

$(* p \leq .05 * * p \leq .01, * p \leq .001)$

Verschillen de mannen en vrouwen onderling? We hebben gekeken nagr de verschillen tussen het PGO en traditioneel curriculum voor de mannen en ook apart voor de vrouwen. De resultaten staan beschreven in de volgende tabel= len.

Opvallend is de hogere scores op alle vier de gebieden door de mannen die traditioneel onderwijs volgen. Zij scoren significant hoger op twee gebieden, namelijk op planmatig gedrag en groepsdynamica.

Tabel 8.13: Kwaliteiten van mannen

\begin{tabular}{|c|c|c|c|c|}
\hline & \multicolumn{2}{|l|}{ PGO } & \multicolumn{2}{|c|}{ traditioneel } \\
\hline & gem. & s.d. & gem. & s.d. \\
\hline 1. planmatig gedrag & 3.7 & $.4(n=42)$ & 4.1 & $6(n=8)^{*}$ \\
\hline 2. probleemoplossen & 3.8 & $3(n=37)$ & 4.0 & $.5(n=8)$ n.s. \\
\hline 3. groepsdynamica & 3.6 & $.4(n=42)$ & 4.1 & $.3(n=8) \cdots$ \\
\hline 4. leidinggeven & 3.8 & $.4(n=45)$ & 3.9 & $.3(n=7)$ n.s. \\
\hline
\end{tabular}

In tabel 8.14 zijn de vrouwen vergeleken. Bij de vrouwen scoren de studentes die het PGO-curriculum volgen hoger op 3 gebieden; alle verschillen zijn significant. Het gaat om de kwaliteiten: planmatig gedrag, probleemoplossen en leidinggeven.

Dit zou kunnen betekenen dat vrouwelijke studenten met name profiteren van het PGO-systeem. Mogelijk kunnen zij bepaalde kwaliteiten goed ontwikkelen binnen het kleinschalige karakter van de onderwijsgroepen in PGO. 


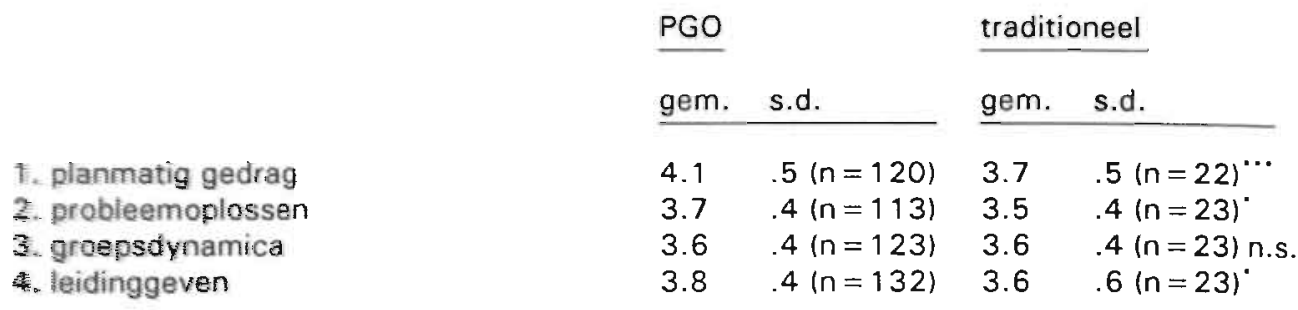

$\left.\|^{*} p \leq .05, * * p \leq .01, * * p \leq .001\right)$

In hoeverre heeft het onderwijs bijgedragen aan deze kwaliteiten? In de volgende tabel staat aangegeven hoe de bijdrage van het onderwijs wordt beoordeeld door de studenten uit het PGO-curriculum en het traditionele curriculum.

Tabel 8.15: Bijdrage van onderwijs (totaal)

\begin{tabular}{|c|c|c|c|c|}
\hline & \multicolumn{2}{|l|}{ PGO } & \multicolumn{2}{|c|}{ traditioneel } \\
\hline & gem. & s.d. & gem. & s.d. \\
\hline 1. planmatig gedrag & 2.9 & $.6(n=157)$ & 2.5 & $.6(n=30)^{\cdots}$ \\
\hline 2. probleemoplossen & 3.3 & $.5(n=148)$ & 3.2 & $.6(n=30)$ n.s. \\
\hline 3. groepsdynamica & 2.9 & $.5(n=163)$ & 2.8 & $.6(n=30)$ n.s. \\
\hline 4. leidinggeven & 3.3 & $.5(n=179)$ & 2.7 & $.6(n=29)^{\cdots}$ \\
\hline
\end{tabular}

$(* p \leq .05, * * p \leq .01, * * p \leq .001)$

De bijdrage van onderwijs aan de verworven kwaliteiten schommelt rond de score 3 . Dit betekent dat men over het algemeen van mening is dat onderwijs enigszins heeft bijgedragen aan de betreffende kwaliteiten. Het blijkt dat PGO in sterkere mate bijdraagt aan planmatig gedrag en leidinggevende kwaliteiten dan het traditionele curriculum. Op alle vier de gebieden is de gemiddelde score door PGO-studenten hoger.

De resultaten van mannen en vrouwen apart worden niet gepresenteerd omdat dit geen opvallende resultaten oplevert. Mannen en vrouwen zijn het erover eens welke bijdrage onderwijs heeft aan de verworven kwaliteiten. 


\section{overige effecten van onderwijs}

In open vragen is geïnformeerd naar andere positieve en negatieve effecten van onderwijs. De antwoorden op deze vragen zijn geïnventariseerd en zo mogelijk ondergebracht in categorieën. Dit levert het volgende beeld van positieve en negatieve effecten van PGO. (zie tabel 8.16 en 8.17).

Tabel 8.16: Positieve effecten van PGO $(n=58)$

\section{frequentie}

1. sociale vaardigheid

2. brede visie en open staan voor andere visie

3. probleemaanpak

4. zelfstandigheid

5. motiverend

6. zelfvertrouwen

7. kritische houding

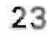

10

10

10

5

3

3

Tabel 8.17: Negatieve effecten van PGO $(n=95)$

frequentie

1. weinig basiskennis

16

2. kennis gaat niet diep genoeg

15

3. niet goed functionerende groepen

15

4. groepsleden die profiteren van anderen (lifters)

13

5. overzicht op probleemgebieden missen

6. ind. specialisatie en differentiatie niet mogelijk 10

7. afhankelijkheid van groepsleden'tutor 10

8. beoordelingssysteem

9

9. persoonlijkheidskenmerken nodig voor succes

10. tijdrovend systeem

6

6

Goede sociale vaardigheden wordt het meest genoemd als positief effect van de opleiding. De voortdurende samenwerking met anderen in de onderwijsgroep speelt hierbij een belangrijke rol. Het ontwikkelen van een brede visie en het openstaan voor andere visies wordt eveneens als een belangrijk gevolg van de opleiding genoemd. De probleemaanpak die wordt geleerd en de zelfstandigheid die wordt verwacht, vindt men ook positief.

De negatieve aspecten van PGO hebben betrekking op de beperkingen van de kennis die men vergaart: weinig basiskennis, kennis gaat niet diep genoeg en het missen van overzicht op probleemgebieden. Niet goed functionerende 
onderwijsgroepen vormen een bron van ergernis. Vaak wordt verwezen naar zogenaamde lifters, studenten, die zelf weinig hebben in te brengen.

In de volgende tabel staat aangegeven welke positieve effecten traditioneel onderwijs heeft. Slechts 9 respondenten hebben deze open vraag beantwoord.

Als belangrijkste positief effect van het traditioneel onderwijs wordt kennisverwerving genoemd. Daarna volgt kritisch denken en zelfstandig werken. Een student geeft aan dat zelfwerkzaamheid noodzakelijk is om de studie te kunnen volbrengen: Je leert initiatieven te ontplooien. Je moet wel... Negatieve effecten staan in tabel 8.19.

Tabel 8.18: Positieve effecten van traditioneel onderwijs $(n=9)$

frequentie

1. kennisverwerving 5

2. kritisch denken 3

3. zelfstandig werken 3

Tabel 8.19: Negatieve effecten van traditioneel onderwijs $(n=15)$

frequentie

1. weinig praktijkgericht

4

2. beperkte invalshoek

4

3. niet leren plannen

2

4. geen aandacht voor sociale vaardigheden 2

5. teveel nadruk op onderzoek 2

6 . onderwijs is massaal 2

Als belangrijkste bezwaar van het traditionele onderwijs wordt het gebrek aan praktijkgerichtheid genoemd evenals de beperkte invalshoek die de studie heeft. Het gaat echter maar om een klein aantal respondenten dat deze vraag heeft beantwoord.

\section{samenvattend}

Er zijn opvallende verschillen tussen het oordeel over de eigen kwaliteiten van de studenten in het PGO-curriculum en studenten die traditioneel onderwijs hebben gevolgd. PGO-studenten geven aan beter in staat te zijn problemen te analyseren, samen te werken met andere disciplines en verschillende vakgebieden te kunnen integreren. Verder geven zij aan regelmatiger te werken en een vergadering te kunnen voorzitten. Studenten die traditioneel 
onderwijs volgen zijn beter in staat om hun prestaties in te schatten en hebben inzicht in hun sterke en zwakke kanten. Gevraagd is in hoeverre het onderwijs hieraan heeft bijgedragen. Respondenten uit de PGO-groep zijn aanzienlijk positiever over de bijdrage van onderwijs aan de verworven kwaliteiten dan de studenten uit de traditionele groep. Een hogere bijdrage van PGO-onderwijs wordt toegeschreven aan planmatig gedrag en leidinggeven. Verder blijken er opvallende verschillen te zijn tussen de mannen en vrouven onderling, in de vergelijking tussen de PGO-groep en de traditionele groep. Bij de mannen scoort de traditionele groep hoger op alle vier de kwaliteiten; de verschillen op planmatig gedrag en groepsdynamica zijn significant. Bij de vrouwen scoort de PGO-groep significant hoger dan de traditionele groep op drie gebieden, namelijk op planmatig gedrag, probleemoplossen en leidinggeven.

Als positieve effecten van PGO worden sociale vaardigheden het meest genoemd. Negatieve effecten zijn de beperkte basiskennis en het feit dat de kennis oppervlakkig wordt gevonden. Slecht functionerende onderwijsgroepen noemt men ook vaker als negatief punt van PGO-onderwijs. Een positief effect van traditioneel onderwijs is kennisverwerving. Als negatief wordt genoemd dat de opleiding weinig praktijkgericht is en dat de invalshoek erg beperkt is.

\section{Discussie}

Tijdens de opleiding is het niet alleen van belang dat studenten kennis en vaardigheden opdoen die ze in hun toekomstige beroep kunnen toepassen. Ook is het van belang vaardigheden te leren om nieuwe kennis te verwerven en vraagstukken in de werksituatie te analyseren en op te lossen. Het gaat hierbij om het leren te leren: het aanleren van een leerhouding om nieuwe kennis te verwerven en in ontwikkeling te blijven. Het leerproces zou ideaal gezien moeten doorlopen na de opleiding in de werksituatie. Vanuit organisaties wordt dit belang aangegeven met de term de lerende organisatie. In de lerende organisatie wordt van leden verwacht dat zij continu in ontwikkeling zijn en in staat blijken in te spelen op nieuwe situaties die zich voordoen. Het beschikken over algemene vaardigheden en bekwaamheden is hierbij van groter belang dan het hebben van specifieke kennis. In het onderwijs wordt gezocht naar nieuwe onderwijsvormen om een algemene leerhouding te bewerkstelligen, bijvoorbeeld door middel van probleemgestuurd onderwijs. Om de aansluiting te onderzoeken van de opleiding op de werksituatie is gekeken naar mogelijke discrepanties tussen de verwachte aansluiting van de kennis en vaardigheden en de feitelijke aansluiting op de functie. Het blijkt clat de feitelijke aansluiting van de kennis, iets gunstiger is dan de verwachte aansluiting van de kennis; de verschillen zijn echter klein. Wat betreft de vaardigheden is een grotere spreiding gevonden bij de feitelijke bruikbaarheid van de vaardigheden dan werd verwacht. Een mogelijke verklaring hiervoor is gelegen in het feit dat PGO-studenten onzeker zijn over de kennis die zij 
hebben opgedaan in de studie. Als negatief aspect van PGO werd in dit onderzoek het meest genoemd: het beschikken over weinig basiskennis; en daarna werd aangegeven dat men vond dat de kennis te weinig diepgaand was. In de praktijk blijkt dit mee te vallen. Respondenten oordelen iets gunstiger over de feitelijke aansluiting van de kennis op de baan. Een ander aspect dat hierbij een rol kan spelen is het selectieproces. Sollicitanten zijn onder meer geselecteerd op basis van hun kennis die voor de functie is vereist.

Opvallend zijn de verschillen tussen de kwaliteiten waarover men aangeeft te beschikken. PGO-studenten beoordelen zich als groep gemiddeld meer planmatig en beter in staat om leiding te geven dan de groep die traditioneel onderwijs volgt. Wanneer we kijken naar de groep mannen en vrouwen apart levert dit een ander beeld op. Mannelijke studenten uit de traditionele groep scoren hoger op planmatig gedrag en groepsdynamische vaardigheden dan de mannelijke studenten uit de PGO-groep. Vrouwen uit de PGO-groep scoren hoger op planmatig gedrag, probleemoplossen en leidinggeven dan de vrouwen uit de traditionele groep.

Studenten uit de PGO-groep geven aan dat het onderwijs vooral heeft bijgedragen aan het ontwikkelen van planmatig gedrag en leidinggeven. Wat betreft de bijdrage van onderwijs zijn er geen significante verschillen tussen mannen en vrouwen. Door mannen en vrouwen wordt de bijdrage van het onderwijs aan de verworven kwaliteiten blijkbaar op dezelfde wijze waargenomen.

Hoe kunnen de gevonden verschillen worden verklaard? De leeromgeving in PGO is mogelijk meer stimulerend voor vrouwelijke studenten dan voor mannelijke studenten. Het kleinschalige karakter van de onderwijsgroep biedt een goede leersituatie voor vrouwelijke studenten om eigen kwaliteiten te ontwikkelen. Het is ook mogelijk dat de probleembenadering erg aanspreekt bij vrouwen.

In traditioneel onderwijs geldt mogelijk dat mannelijke studenten hier meer van profiteren. De scores van de mannen op de kwaliteiten waren immers hoger voor de traditionele groep dan voor de PGO-groep. We moeten echter bedenken dat het hierbij om een kleine steekproef gaat. Bovendien bleken de studenten uit de traditionele groep iets minder ver te zijn in de studie dan de PGO-groep. Het is echter een interessant gegeven om verder onderzoek op te richten.

Uit de open vragen naar de positieve en negatieve effecten van het onderwijs, blijkt dat het traditionele onderwijs eenzijdig is gericht op kennisverwerving en daarbij een beperkte invalshoek kiest, terwijl het PGO-onderwijs een bijdrage levert aan goede sociale vaardigheden en tekort schiet in de hoeveelheid basiskennis en de diepgang ervan. Hierboven is aangegeven dat deze beperkte kennis in de praktijk in de meeste gevallen geen probleem blijkt te zijn. Over de feitelijke aansluiting van de kennis die men in de opleiding heeft geleerd op de functie is men positiever dan men van te voren verwachtte. 


\section{De overgang van opleiding naar arbeidsmarkt, samenvatting, discussie en conclusies}

In deze studie is het overgangsproces van de opleiding naar de arbeidsmarkt onderzocht. Het overgangsproces is een cruciale fase in de carrière-ontwikkeling, waarvan het belang meestal niet wordt onderkend. Er is sprake van een duidelijke scheiding tussen opleiding en arbeidsmarkt, zowel in de literatuur over dit thema als in de praktijk. Studenten ervaren deze twee periodes als sterk verschillend. Vanwege de gerichtheid op de studie en vanwege onvoldoende besef van het belang van een goede voorbereiding, begint men relatief laat met een oriëntatie op de arbeidsmarkt. Hierdoor verloopt de voorbereidingsfase grotendeels impliciet, waardoor mogelijk onnodige vertraging wordt opgelopen. In de literatuur is een blinde vlek te zien tussen de opleidingsperiode van de carrière-ontwikkeling en de periode van de start in de eerste baan in een organisatie. Het overgangsproces van opleiding naar arbeidsmarkt lijkt zowel buiten het interessegebied van de opleiding als buiten de interesse van organisaties te vallen. Het problematiseren van deze fase heeft als doel inzicht te geven in een cruciale periode in de loopbanen van studenten cq afgestudeerden, waarbij opleiding en arbeidsmarkt niet meer uitsluitend als aparte entiteiten worden beschouwd maar in elkaars verlengde kunnen worden gezien.

In dit hoofdstuk wordt allereerst een samenvatting gegeven van de opzet van het onderzoek en de belangrijkste bevindingen. Vervolgens wordt getracht de resultaten te integreren. Vanuit verschillende perspectieven worden de resultaten bediscussieerd. Het overgangsproces wordt in zijn totaliteit nader beschouwd. De onderzoeksresultaten worden gerelateerd aan andere studies over carrière-ontwikkeling. Verschillen tussen mannen en vrouwen in de fase komen aan de orde. Vervolgens wordt de rol van de opleiding in het overgangsproces besproken.

\section{Samenvatting}

In hoofdstuk 1 worden verschillende invalshoeken van carrière-studies belicht. Ingegaan wordt op de theoretische achtergrond van het begrip carriere. Empirische gegevens en opvattingen over de verschillen in de carrière tussen 
mannen en vrouwen worden gepresenteerd. Een model van een overgangsproces van Nicholson en West (1988) dat ingaat op de specifieke vereisten in de verschillende fasen in dit proces, komt aan de orde. De aard van de functie en de wijze waarop deze wordt vervuld, zijn van invloed op het ervaren van succes. In de succescyclus van Hall (1976) wordt beschreven welke aspecten van de werksituatie van invloed zijn op het ervaren van succes. In de laatste paragraaf wordt de rol van de opleiding in het overgangsproces aangegeven. In hoofdstuk 2 wordt ingegaan op de carrière-ontwikkeling van studenten, tijdens de overgang van opleiding naar arbeidsmarkt. De overgang van opleiding naar arbeidsmarkt wordt beschouwd als een opeenvolging van een viertal fasen waarin verschillende taken centraal staan: de voorbereidingsfase en de fase van baan verwerven, die beide voornamelijk tijdens de studie plaatsvinden; de fase van de eerste werkervaringen en de fase van het ervaren van succes in het werk die beide plaatsvinden na aanvang van de eerste baan. Deze vier fasen zijn uitgebreid beschreven, met name is ingegaan op de factoren die een rol zouden kunnen spelen in de betreffende fase.

In hoofdstuk 3 wordt de opzet van het onderzoek besproken. Om recht te doen aan het procesmatige karakter van de overgangsperiode van opleiding naar arbeidsmarkt is gekozen voor een longitudinale opzet van het onderzoek. Een groep ouderejaars studenten werd gevolgd vanaf de voorbereidingsfase tot na hun afstuderen. In totaal zijn vier deelonderzoeken verricht. Hiervan zijn drie deelstudies gericht op de opeenvolgende fasen van het overgangsproces. De loopbaan-enquête geeft inzicht in de wijze waarop studenten zich voorbereiden op de arbeidsmarkt. Het tweede deelonderzoek bestaat uit enkele vragenlijsten en psychologische tests. Het derde meetmoment betreft een carrière-interview waarbij een groep afgestudeerden werd geïnterviewd over hun ervaringen in de eerste baan.

Naast dit onderzoek naar de verschillende fasen van het overgangsproces wordt specifiek aandacht geschonken aan de rol van de opleiding in de overgang van opleiding naar arbeidsmarkt. Verondersteld werd dat probleemgestuurd onderwijs beter aansluit op de beroepspraktijk dan het meer traditioneel opgezette onderwijs.

In hoofdstuk 4 worden de resultaten beschreven van de voorbereidingsfase. In deze fase stond het sollicitatiegedrag centraal. Dit is de geneigdheid om te gaan solliciteren naar een bepaalde functie, in de laatste fase van de studie. Onderzocht wordt in hoeverre kennis van de arbeidsmarkt, doelgerichtheid, persoonlijkheidskenmerken en de persoonlijke situatie in deze fase van belang zijn.

Uit de resultaten komt naar voren dat doelgerichtheid, prestatiegerichtheid en leeftijd kunnen worden beschouwd als determinanten van sollicitatiegedrag. De variabelen met betrekking tot kennis van de arbeidsmarkt, namelijk werkervaring en stage-ervaringen, blijken in het verklaringsmodel geen rol te spelen. Op enkele punten blijken er verschillen te zijn tussen mannen en vrouwen in de voorbereidingsfase. Vrouwelijke studenten geven aan dat zij in hogere ma- 
te doelgericht zijn en blijken meer prestatiegericht te zijn dan hun mannelijke collega's.

In hoofdstuk 5 worden de resultaten besproken van de fase van baan verwerven. In deze fase wordt onderzocht in hoeverre arbeidsmarktgerichtheid, sollicitatievaardigheden, persoonlijkheidsaspecten en de persoonlijke situatie van invloed zijn op het krijgen van een baan. Uit de resultaten blijkt dat het aantal uren dat men wil werken en self-efficacy beschouwd kunnen worden als determinanten van het verwerven van een baan. Onder self-efficacy verstaan we de verwachting dat de gewenste baan wordt bereikt. Het nastreven van een hogere functie, het nastreven van zelf-ontplooiing en zelfwaardering blijken een indirecte rol te spelen bij het verwerven van een baan. Zelfwaardering blijkt van invloed te zijn op self-efficacy. Het nastreven van zelf-ontplooiing en het nastreven van een hogere functie zijn van invloed op de gewenste omvang van het dienstverband. Mannen en vrouwen verschillen op de twee variabelen die direct van invloed zijn op het verwerven van een baan, namelijk de gewenste omvang van het dienstverband en self-efficacy.

In hoofdstuk 6 staan de resultaten beschreven die zijn gevonden met betrekking tot de fase van de eerste werkervaringen. In deze fase stond de waardering voor de werksituatie centraal. Onderzocht werd in welke mate cognities, omgevingskenmerken, overgangskenmerkenen functiekenmerken in deze fase van belang zijn. Het blijkt dat de waardering van de baan vooral wordt bepaald door de sociale steun die men krijgt, de introductieperiode, de mate van uitdaging van de baan en de periode waarin men werkzaam is. De mate van tevredenheid over de feedback blijkt indirect van invloed te zijn. Het zijn dus vooral omgevingskenmerken die van belang blijken in de eerste periode in de baan.

De resultaten met betrekking tot de fase van het ervaren van succes staan centraal in hoofdstuk 7 . In deze fase werd onderzocht of functiekenmerken, zelfmanagement, loopbaankenmerken en opleidingsaspecten cen rol spelen bij het ervaren van succes. Het blijkt dat de mate van autonomie in het werk, de planning van de werkzaamheden en de bruikbaarheid van de geleerde vaardigheden direct van invloed zijn op het ervaren van succes. De bruikbaarheid van de vaardigheden blijkt ook indirect van invloed te zijn op succes, via de planning van de werkzaamheden.

In hoofdstuk 8 wordt ingegaan op de aansluiting van de opleiding op de werksituatie. De resultaten van het vierde deelonderzoek worden in dit hoofdstuk beschreven. Hierin staat de vergelijking centraal van de kwaliteiten van studenten die probleemgestuurd onderwijs volgen, met studenten die een meer traditioneel opgezet curriculum volgen. PGO studenten geven aan beter in staat te zijn om problemen te analyseren, samen te werken met andere disciplines en verschillende vakgebieden te kunnen integreren. Studenten die traditioneel onderwijs volgen, geven aan dat zij beter in staat zijn om hun prestaties in te schatten en dat zij een goed inzicht hebben in hun sterke en zwakke kanten. PGO-studenten zijn aanzienlijk positiever over de bijdrage van de opleiding aan deze kwaliteiten dan de studenten uit de traditionele groep. Er zijn 
opvallende verschillen tussen de mannelijke en vrouwelijke studenten. Het lijkt erop dat vrouwen in hogere mate profiteren van probleemgestuurd onderwijs dan hun mannelijke collega's.

\section{Het overgangsproces nader beschouwd}

Opvallend is dat in de vier fasen steeds verschillende kenmerken of taken cruciaal zijn. In de voorbereidingsfase gaat het om het ontwikkelen van de juiste werkhouding: in staat zijn om doelen te formuleren, die realistisch en haalbaar zijn en op planmatige wijze toewerken naar dit doel. Uit de onderzoeksresultaten is gebleken dat met name doelgerichtheid en prestatiegerichtheid van invloed zijn op sollicitatiegedrag. Dit is de geneigdheid om gericht te gaan solliciteren naar een bepaalde functie. De concrete plannen die men heeft na afstuderen en de mate waarin men zichzelf in staat acht om planmatig te werken, zijn met name relevant. Leeftijd blijkt direct van invloed te zijn op sollicitatiegedrag en indirect via de concrete plannen die men heeft na afstuderen.

In de voorbereiding zou dus een begin moeten worden gemaakt met de eerste stappen zoals beschreven in de succescyclus van Hall (1976): het formuleren van doelen en gericht werken aan het realiseren van de doelen. Dit kan inhoudelijk worden toegepast in de studie, bijvoorbeeld bij het studeren voor een toets, maar het heeft ook betrekking op het formuleren van carrièredoelen en het maken van een planning om deze doelen te concretiseren. In de opleiding is dus niet alleen het opdoen van kennis en vaardigheden van belang, maar ook en vooral het aanleren van een effectieve werkstijl en het aanwenden van deze houding ten behoeve van de eigen carrière. Dit komt overeen met de opmerkingen van Swieringa en Wierdsma (1990) over het ontwikkelen van competenties die van belang zijn voor het werken in organisaties.

In de fase van baan verwerven zijn met name de motivatie en vertrouwen in eigen kwaliteiten van belang. De fase van baan verwerven is succesvol doorlopen als een betaalde baan wordt verkregen. Uit de resultaten van het onderzoek is gebleken dat met name de gewenste omvang van het dienstverband van invloed is op het verwerven van een baan. Hoe meer uur per week men wil werken, des te vaker heeft men een baan na afstuderen. $\mathrm{Er}$ is een relatie gevonden tussen self-efficacy en het verwerven van een baan. De overtuiging dat de gewenste baan zal worden bereikt, leidt vaker tot het daadwerkelijk realiseren van dit beeld. Zelfwaardering heeft een indirecte invloed op het verwerven van een baan, via self-efficacy. Deze resultaten verwijzen naar het belang van de persoonlijkheid bij het verkrijgen van een baan en de ondergeschikte rol van de kennis waarover men beschikt. In de literatuur over selectieprocedures komt dit belang eveneens naar voren. Van Vianen (1987) geeft aan dat met name in de laatste fase van de selectie, de persoonlijkheid van de kandidaat vaak de doorslag geeft. 
$\mathrm{Na}$ aanvang van de eerste baan start een nieuwe periode. Omgevingsfactoren blijken cruciaal in de fase van de eerste werkervaringen, waarbij de waardering van de werksituatie met name wordt bekeken. Sociale steun, de introduktieperiode en het krijgen van feedback op de werkzaamheden zijn van invloed op het waarderen van de werksituatie. De samenwerking met collega's en de werksfeer blijken bronnen van positieve ervaringen. Het gebrek aan begeleiding en aan inwerktijd is vaak de oorzaak van negatieve ervaringen. Door de organisatie en de organisatiecultuur werd men vaker verrast. Men voelde zich blijkbaar niet voorbereid op de manier waarop wordt samengewerkt in organisaties. Hierbij werd vooral gedoeld op politieke aspecten en machtsfactoren. Naarmate men langer werkzaam was in de baan, nam de waardering af. Volgens Louis (1980) is essentieel in deze fase dat betekenis wordt toegekend aan de nieuwe omgeving. Ook Josefowitz en Gadon (1988) benadrukken het socialisatieproces in de nieuwe organisatie. Het ligt dan ook voor de hand dat een nieuwkomer in de eerste tijd erg gericht is op de omgeving en zich afhankelijk voelt van de bereidheid van collega's om behulpzaam te zijn en begeleiding te bieden. Na enige tijd leert men ook de negatieve kanten van de organisatie kennen, waardoor de waardering voor de baan kan afnemen.

Bij het ervaren van succes blijken de eigen capaciteiten essentieel. Uit de onderzoeksresultaten kwam naar voren dat de planning van werkzaamheden erg belangrijk is. Goed kunnen inschatten hoeveel tijd een bepaalde taak kost en prioriteiten kunnen vaststellen zijn hierbij essentieel. Autonomie in het werk speelt ook een belangrijke rol. Vooral als een doel wordt bereikt door middel van onafhankelijke inspanning zal dit leiden tot het ervaren van succes. Verder draagt de aansluiting van de vaardigheden die in de opleiding zijn geleerd bij aan het ervaren van succes. Uit het verklaringsmodel van deze fase blijkt dat het belang dat men hecht aan de loopbaan indirect van invloed is op het ervaren van succes, via de mate van autonomie in het werk. Het gaat in deze fase dus vooral om de persoonlijke capaciteiten om doelgericht en planmatig de juiste vaardigheden toe te passen gericht op datgene wat men wil bereiken. Deze prestatie is een duidelijke eigen verdienste.

Hiermee zijn de vier fasen getypeerd: achtereenvolgens $<$ ijn een doelgerichte werkhouding, een gemotiveerde persoonlijkheid, een stimulerende werkomgeving en een capabel persoon essentieel in dit proces. Verschillende elementen en taken staan centraal in de afzonderlijke fasen. Hoe kunnen we dit hele proces dan beschouwen? Het lijkt erop dat het overgangsproces van de opleiding naar de arbeidsmarkt uit vier fasen bestaat die discontinu <ijn. Dit wil zeggen dat het om periodes gaat die fundamenteel verschillen en verschillende taken vereisen van de studenten cq afgestudeerden. Dit is vergelijkbaar met de indeling van Dalton en Thompson (1986). Zij beschrijven ecn vierfasenmodel waarin een loopbaan zich kan ontvouwen. Ook bij hen bestaat een fundamenteel onderscheid tussen de verschillende stappen. Bepaalde taken horen bij een bepaalde fase, maar zijn disfunctioneel in een volgende periode. Ook Nicholson en west (1988) noemen discontinuïteit als een van de kenmerken van de overgangscyclus. De cyclus heeft discontinue fasen met elk 
kwalitatief verschillende taken, ervaringen, problemen en oplossingen. Daarnaast noemen zij de onderlinge afhankelijkheid van de fase: wat in een bepaalde periode gebeurt, heeft effect op de volgende fasen. Een ander kenmerk van de cyclus die zij beschrijven, is de cirkelvorm. De laatste fase is vergelijkbaar met de eerste, waardoor een blijvende beweging wordt aangegeven. In deze $z i n$ is het overgangsproces verschillend. Bij het overgangsproces gaat het om een specifieke fase in de carrière-ontwikkeling die eenmalig is en niet herhaald wordt. In de inhoudelijke betekenis van de fase gaat het meer om een ontwikkelingsproces, vergelijkbaar met de fasen in de loopbaan zoals door Dalton en Thompson beschreven.

Wat verder opvalt aan de typering die is gegeven voor de vier fasen: de eerste en vierde fase bevatten elementen uit de succescyclus, namelijk de eerste stappen en de laatste stappen uit deze cyclus van Hall (1976). De eerste fase wordt namelijk het meest gekenmerkt door een doelgerichte werkhouding; in de laatste fase bleken de capaciteiten essentieel voor het ervaren van succes. De tweede en derde fase bevatten duidelijk de kenmerken die door Porter et al. (1975) worden beschreven in de keuze- en adaptatieprocessen bij de ontwikkeling van de relatie tussen individu en organisatie. Een beschrijving van het overgangsproces van opleiding naar arbeidsmarkt zou beide benaderingen moeten bevatten.

\section{De overgang van opleiding naar arbeidsmarkt in carrière- theoretisch perspectief}

Wat is de betekenis van het onderzoek dat in dit proefschrift is beschreven in relatie tot bestaande carrière-theorieën? In de inleiding werd aangegeven dat in de bestaande theorieën sprake is van een duidelijke scheiding tussen opleiding en arbeidsmarkt. Onderzoek naar het overgangsproces kan gezien worden als een poging om deze kloof te overbruggen; om inzicht te geven in een belangrijke periode in de carrière-ontwikkeling waarover weinig specifieke literatuur is verschenen.

Bestaande modellen op het terrein van de carrière-ontwikkeling gaan vooral in op de verschillende fasen in de loopbaan, die apart worden beschreven (Super, 1957; Miller \& Form, 1964; Lievegoed, 1991). Het gaat daarbij vaak om lange periodes van ongeveer 10 jaar. $\mathrm{Er}$ is weinig aandacht voor de overgang van de ene fase naar de andere. De modellen zijn nogal grofmazig van karakter. Het onderzoek naar de overgang van opleiding naar arbeidsmarkt zoomt als het ware in op een specifieke en relatief korte periode in de loopbaan, waarin de overgang van de opleidingsfase naar de werksituatie wordt doorlopen. Het levert meer fijnmazige informatie over de periode tussen de opleidingsfase en de fase van de eerste werkervaringen, die elk afzonderlijk in de bestaande theorieën zijn terug te vinden.

In de grove indelingen voor het beschrijven van de carrière ligt meestal de nadruk op de stabiliteit van de verschilende fasen. Het onderzoek naar het 
overgangsproces van opleiding naar arbeidsmarkt is gericht op veranderingen in de carrière. Verder worden in dit onderzoek aspecten van de interne carrière gecombineerd met aspecten van de externe carrière (Derr \& Laurent, 1989). De interne carrière heeft betrekking op het psychologisch proces van het individu tijdens de loopbaan, motivatie en keuzeprocessen spelen hierbij een rol. De externe carrière heeft betrekking op de mogelijkheden op de arbeidsmarkt en in de organisatie waarin men werkt. Beide aspecten blijken op verschillende momenten tijdens het overgangsproces van opleiding naar arbeidsmarkt cruciaal te zijn.

Het onderzoek dat in dit proefschrift wordt beschreven zoomt in op een specifieke periode in de carrière-ontwikkeling en beschrijft deze fase van de carrière in de context van de gevolgde opleiding en van de werksituatie. Dit ligt in de lijn van Bailyn (1989), die het uitvoeren van carrière-studies bepleit in de context waarin de carrière zich ontwikkelt, vanwege de eenzijdige nadruk op het psychologische perspectief in de meeste studies. Kenmerken van de opleiding én van de werksituatie blijken van belang voor het doorlopen van een succesvolle overgang naar de arbeidsmarkt.

\section{Verschillen tussen mannen en vrouwen in het overgangs- proces}

In geen van de vier verklaringsmodellen van de fasen van het overgangsproces komt de variabele geslacht naar voren. Hieruit zouden we kunnen concluderen dat mannen en vrouwen op vergelijkbare wijze het overgangsproces doorlopen. Er zijn echter wel verschillen gevonden bij enkele variabelen en bij de toelichting die soms wordt gegeven. Hieruit komt een bepaald consistent beeld naar voren waardoor het lijkt alsof de overstap naar de arbeidsmarkt voor vrouwen minder vanzelfsprekend is dan voor mannen. Waar is dit op gebaseerd? Het blijkt dat vrouwen naar verhouding vaker van plan zijn om het solliciteren uit te stellen. In de laatste fase van de studie zijn zij minder vaak bezig met solliciteren of van plan hiermee op korte termijn te beginnen. Daarentegen beoordelen vrouwen zichzelf hoger op planmatig gedrag en op prestatiegerichtheid. De vrouwen in de onderzoeksgroep zijn gemiddeld jonger dan de mannen. Het lijkt er dus op dat de vrouwen die deel uit maken van deze studie, een geschikte werkstijl hebben ontwikkeld, maar geneigd zijn om het afstuderen enige tijd uit te stellen. De jongere leeftijd blijkt hiermee samen te hangen.

In de fase van baan verwerven zijn er eveneens verschillen op de cruciale variabelen. Er lijkt een tendens te zijn dat mannen vaker een baan hebben dan vrouwen. Vrouwelijke studenten zijn vaker van plan in deeltijd te werken en hebben een lager zelfvertrouwen met betrekking tot het bereiken van de gewenste baan. Deze lagere self-efficacy is niet gebaseerd op feitelijke vaardigheden in het solliciteren. Uit een onderzoek naar de effectiviteit van de 
training solliciteren bleek dat vrouwelijke studenten op enkele punten beter werden beoordeeld door externe deskundigen (Broekmate \& Schreurs, 1994). In de fase van de eerste werkervaringen worden door mannen en vrouwen verschillende positieve en negatieve ervaringen gerapporteerd. Vrouwen rapporteren in verhouding vaker dan mannen dat zij het positief vinden te worden geaccepteerd en gewaardeerd in de organisatie. Mannen noemen de inhoud van het werk vaak als een positieve ervaring. Als negatieve ervaring wordt uitsluitend door vrouwen genoemd teveel vrijheid en verantwoordelijkheid. Door vrouwen worden in verhouding meer negatieve ervaringen gerapporteerd, door mannen worden meer positieve ervaringen genoemd. Bij de kenmerken van rolverandering noemen vrouwen vaker het verplichte karakter van de werksituatie. Bij vrouwen ontbreekt iets vaker een inwerkperiode. Daarentegen zijn ze toch meer tevreden over de inwerktijd dan mannen.

In deze periode vindt de socialisatie in de organisatie plaats. Zowel voor mannen als voor vrouwen blijken omgevingsfactoren in deze factoren cruciaal. Toch lijkt het erop dat deze fase voor vrouwen moeizamer verloopt dan voor mannen: zij rapporteren meer negatieve ervaringen en minder positieve. Verder is opvallend dat 'geaccepteerd worden als collega' een belangrijke positieve ervaring is. Had men dit niet verwacht? Wordt het als uitzonderlijk gezien dat vrouwen een waardevolle bijdrage kunnen leveren in een organisatie? De onzekerheid van vrouwen ten aanzien van de vrijheid en verantwoordelijkheid valt eveneens op. Blijkbaar is er behoefte aan duidelijke begeleiding en feedback van anderen in deze fase van het overgangsproces.

Vanwaar deze subtiele verschillen tussen mannen en vrouwen? Waarschijnlijk hangt dit samen met de ongelijke arbeidsmarktpositie van vrouwen en mannen, zowel in kwantitatief als in kwalitatief opzicht. In Nederland is sinds kort de participatie van vrouwen in de beroepsarbeid sterk toegenomen. Veel vrouwen werken echter in deeltijd. Het aandeel dat vrouwen leveren aan de totale hoeveelheid arbeidsjaren van de werkende bevolking is beduidend minder toegenomen. Verder blijkt dat vrouwen in hogere functies nog altijd zeldzaam zijn. Verklaringen voor de ongelijke arbeidsmarktpositie stellen de aanbodzijde centraal (bijvoorbeeld socialisatie-theorieën) of zijn gericht op de vraagzijde van de arbeidmarkt. Socialisatie van mannen en vrouwen zal van belang zijn in de verklaring van deze verschillen. Discriminatie door werkgevers vormt een verklaring vanuit de vraagzijde bezien. Beide factoren zullen mogelijk een rol spelen in het overgangsproces van de opleiding naar de arbeidsmarkt. Astin (1984) noemt beide aspecten in haar model van carrièreontwikkeling. Zij stelt dat verwachtingen gedeeltelijk gevormd zijn door socialisatie en door de perceptie van kansen. De lagere verwachtingen van vrouwen om de gewenste functie te bereiken hangt volgens haar met beide aspecten samen. 


\section{De rol van de opleiding in het overgangsproces}

Kennis en vaardigheden die in de opleiding zijn verworven kunnen bijdragen aan een goede overgang naar de arbeidsmarkt. Welke rol spelen kennis en vaardigheden in dit proces? Het blijkt dat in de fase van het ervaren van succes de opleiding van belang is. Voor de meer specialistische functics is de aansluiting van de kennis beter dan voor de generalistische functies. Men name in de beginperiode geeft men aan dat de aansluiting van de vaardigheden goed is. Mogelijk geven de vaardigheden waarover men beschikt houvast in de eerste periode in de nieuwe baan. Verder blijken vaardigheden een direct effect te hebben op het ervaren van succes. In staat zijn een goede planning te maken blijkt eveneens van invloed te zijn op succes. Dit kan ook als een vaardigheid worden beschouwd.

De bijdrage van probleemgestuurd onderwijs lijkt zich te onderscheiden van meer traditionele onderwijsvormen. PGO-studenten geven aan meer planmatig te zijn en beter te kunnen leidinggeven dan de studenten die meer traditioneel onderwijs hebben gevolgd. Verder blijkt een opvallend verschil tussen de kwaliteiten van mannen en vrouwen. Mannelijke studenten uit de traditionele groep geven aan in hogere mate te beschikken over planmatig gedrag en groepsdynamische vaardigheden, dan hun mannelijke collega's uit de PGOgroep. Vrouwelijke studenten uit de PGO-groep geven aan dat zij in hogere mate beschikken over planmatig gedrag, probleemoplossend vermogen en leidinggevende kwaliteiten, dan de vrouwen uit de traditionele groep. Dit lijkt erop te wijzen dat vooral vrouwen in sterke mate profiteren van probleemgestuurd onderwijs. Persoonlijke kwaliteiten en vaardigheden komen binnen PGO goed tot ontplooiing.

Uit de antwoorden op de open vragen valt op dat de positieve en negatieve effecten van traditionele onderwijs en van PGO tegengesteld zijn. De gerapporteerde sterke kant van traditioneel onderwijs, namelijk kennisverwerving, wordt als zwakke kant van PGO aangegeven. PGO-studenten veronderstellen weinig basiskennis te hebben en vinden bovendien dat de kennis te oppervlak$\mathrm{kig}$ is. Als sterke kanten van PGO noemen studenten de sociale vaardigheden die men leert en de brede visie die wordt ontwikkeld. Traditionele studenten noemen het gebrek aan praktijkgerichtheid een zwak punt evenals de beperkte invalshoek.

De inschatting van PGO-studenten dat hun basiskennis beperkt is, blijkt in de praktijk geen probleem te zijn. In de fase van de eerste werkervaringen werd door afgestudeerden niet gerapporteerd dat hun kennis ontoereikend was. Mogelijk dat men in de praktijk toch blijkt te beschikken over voldoende kennis of dat men goed in staat is om de kennis alsnog te verwerven.

De praktijkgerichte aanpak en de grote nadruk op het verwerven van vaardigheden in probleemgestuurd onderwijs blijken van belang te zijn voor de overgang naar de arbeidsmarkt. 



\section{Summary}

This study examines the transition process from education to labour market. Although this transition process constitutes a crucial stage in career development, its importance usually is not recognized. A clear distinction can be made between education and labour market, both in the literature on this subject and in practice. Students experience these two periods as strongly different. Being focused on their studies and insufficiently aware of the importance of an appropriate preparation, students are relatively late at orienting themselves on the labour market. As a result, the preparation stage passes implicitly, risking unnecessary delay. The literature shows a blind spot between the training period of career development and the first job in an organization. The transition process from education to labour market seems to be outside the line of both organizations and educational institutions. The purpose of turning to this process as an issue is to provide insight into the crucial periods in the careers of students or rather graduates. To this end, education and labour market are no longer regarded solely as separate entities, but can be considered to be in line with each other.

Chapter 1 discusses several perspectives of career studies, elaborating on the theoretical background of the concept of career. Empirical data and opinions about the differences in the careers of men and women are presented. A transition process model of Nicholson and West (1988) is discussed that elaborates on the specific demands of the various stages in this process. The experience of success is influenced by the nature of the function and how it is fulfilled. The success cycle of Hall (1976) describes which aspects of the work context are of influence on the experience of success. In the final section, the role of education is stated.

Chapter 2 elaborates on career development among students during the transition period from education to labour market. This period is considered to be a chain of four stages, each of them centering on various tasks: the preparation stage and the stage of job acquisition, both largely addressed during the study; the stages of early work experiences and the experience of success at work, both taking place after assuming the first job. Describing these four stages, special attention is paid to the factors that might play a role in each single stage.

Chapter 3 discusses the design of the study. The choice for a longitudinal approach does justice to the process-oriented nature of the transition period from education to labour market. A group of advanced students were observed from the preparation stage until the period after graduation. In total, 
four sub-studies have been undertaken, three of which are aimed at the successive stages of the transition process. First, the career questionnaire provides insight into how students prepare themselves for labour market entry. The second sub-study comprises a number of questionnaires and psychological tests. The third moment of measuring is the career interview, as part of which a group of graduates were questioned about their experiences in their first jobs.

The fourth sub-study focuses attention on the role of the education in the transition from education to labour market. Problem-based learning is assumed to be better adjusted to the labour market than traditional education.

Chapter 4 describes the results of the preparation stage. In this stage the focus was on job application behaviour, meaning the tendency to apply for a certain function in the final stage of the study. Research is done on the importance of labour market awareness, goal-orientedness, personality characteristics, and personal circumstances in the preparation stage. The results demonstrate that goal-orientedness, performance orientation, and age may be considered determinants of job application behaviour. The variables related to labour market awareness, work and practical period experiences, appear not to play a role in the explanation model. The preparation stage shows a few differences between men and women. It turns out that in this stage female students show more goal-orientedness and performance orientation than their male colleagues.

Chapter 5 discusses the results of the job acquisition stage. With respect to this stage it is examined to what extent getting a job is influenced by labour market orientation, application skills, personality aspects and personal circumstances. It appears from the outcomes that the applicant's desired work time and self-efficacy can be considered determinants for job acquisition. Self-efficacy means the expectation that the desired job is achieved. As it turns out, job acquisition indirectly involves aspirations of upward job change, self-development, and self-esteem. In addition, selfesteem appears to affect self-efficacy. The desired work time related to the job depends on aspirations of self-development and upward function change. Men and women differ in the two variables that directly affect job acquisition, namely the desired work time and self-efficacy.

Chapter 6 describes the results related to the stage of early work experience. This stage focused on the estimation of the work situation. The aim was to determine the importance of cognitions and environmental, transition, and function characteristics. As it turns out, job satisfaction is largely dependent on social support, the introductory period, challenging job demands, and the period of job tenure. Furthermore, it is indirectly influenced by satisfaction about feedback. So the first weeks or months of a new job is mainly determined by situational forces.

The results related to the stage of the experience of success are the focus of chapter 7 . In this stage, it was examined whether the experience of success involves function characteristics, self-management, career characteristics, and 
educational aspects. The experience of success turns out to be directly influenced by the level of autonomy, the planning of one's duties, and the use of the acquired skills. The use of the acquired skills appears to have an indirect influence on success as well, namely through the planning of duties. Chapter 8 elaborates on how education is geared towards the labour market, describing the results of the fourth sub-study. The focus is on the comparison between the qualities of students attending problem-based learning and students attending a more traditional curriculum. Problem-based learning students indicate that they have improved their ability to analyze problems, to collaborate with other disciplines, and to integrate several fields. Students involved in traditional learning indicate that they are better at estimating their performances and that they are aware of their strong and weak sides. Problem-based learning students are far more favourable to the idea that their education has contributed to these qualities than students from the traditional group. In addition, male and female students show striking differences. Women seem to gain more by problem-based learning than their male colleagues.

Chapter 9 discusses the transition process from education to labour market. It is striking that the four stages show different crucial characteristics or tasks. The preparation stage is concerned with developing the appropriate work attitude: being able to formulate realistic and feasible objectives; and working up to these objectives by a systematic approach. So education is not only a matter of acquiring knowledge and skills but, particularly, of adopting an effective work attitude and applying this attitude for the sake of one's own career.

The stage of job acquisition is chiefly a matter of motivation and confidence in personal qualities. The job acquisition stage has been completed successfully if a paid job is achieved. The results refer to the importance of personality in the job acquisition process and the inferior role of the available knowledge. This importance is also stressed by the literature on selection procedures.

Starting one's first job means entering a new period. Factors related to work context turn out to be crucial in the stage of early work experiences, the focus being on the estimation of the work situation. Collaboration with colleagues and the work atmosphere appear to be sources of positive experience. Negative experiences are often caused by the lack of both supervision and initial training. Newcomers were often surprised by the organization and the organizational culture. Apparently, they felt inappropriately prepared for the intra-organizational collaboration, making reference to political aspects and power factors in particular.

An individual's qualities turn out to be essential for the experience of success. The research results reveal that the planning of duties is very important. In this respect, estimating the required time for a certain duty and setting priorities are essential. Autonomy in the work plays an important role as well. 
So this stage is mainly concerned with personal abilities to use the right skills, effectively and methodically, to attain one's goal. 


\section{Literatuur}

Arnold, J. (1985). Tales of the Unexpected: Surprises Experienced by Graduates in the Early Months of Employment. British Journal of Guidance \& Counseling, 13, 308-319.

Arthur, M.B., Hall, D.T., \& Lawrence, B.S. (Eds.) (1989). Handbook of career theory. Cambridge: University Press.

Astin. H.S. (1984). The meaning of work in women's lives: a socio-psycological model career choice and work behavior. The Counseling Psychologist, 12, 117-126.

Bandura, A. (1977). Self-efficacy: Toward a Unifying Theory of Behavioral Change. Psychological Review, 84, 191-215.

Barrows, H.S. (1980). Problem-based learning: an approach to medical education. New York: Springer.

Bentler, P.M. (1995). EQS, structural equations program manual. Encino, CA: Multivariate Software.

Bos-Boers, M. (1992). Ontwikkelingen in de functiekwaliteit van vrouwelijke en mannelijke afgestudeerden van de landbouwuniversiteit Wageningen. Wageningen: Landbouwuniversiteit.

Bouter, L.M., \& Van Dongen, M.C.J.M. (1991). Epidemiologisch onderzoek: Opzet en interpretatie. Houten: Bohn Stafleu Van Loghum.

Bowditch J.L., \& Buono, A.F. (1990). A primer on Organizational Behavior. New York: Wiley.

Breukelen, G. van \& Talsma, P. (1994). De analyse van vragenlijsten. Methodologie en Statistiek (module 19). Maastricht: Rijksuniversiteit Limburg.

Broekmate, J., \& Schreurs, M.L.J.J. (1994). Effecten van trainingen solliciteren en loop. baanontwikkeling: Een evaluatie. Maastricht: Rijksuniversiteit Limburg.

Crites, J.O. (1971). Vocational psychology: The Study of Vocational Behavior and Development. New York: McGraw-Hill.

Crites, J.O. (1976). A Comprehensive Model of Career Development in Early Adulthood. Journal of Vocational Behavior, 9, 105-118.

Cummings, T.G., \& Huse, E.F. (1989). Organization development and change. St Paul: West Publishing.

Dalton, G.W., \& Thompson P.H. (1986). Novations: Strategies for career management. Glenview, IL: Scott Foresman.

Dam, K. van (1995). Het vijffactormodel en personeelsselectie. Nederlands Tijdschrift voor de Psychologie, 50, 149-161.

Derr, C.B. (1986). Managing the new careerists. San Francisco: Yossey Bass.

Derr, C.B., \& Laurent, A. (1989). The internal and external career: a theoretical and crosscultural perspective. In: M.B. Arthur, D.T Hall \& B.S. Lawrence (Eds.) Handbook of career theory. (pp. 454-471. Cambridge: University Press.

Dietvorst, C. (1992). Doctoraal Farmaceuten op de arbeidsmarkt: Verslag van een onderzoek onder afgestudeerden van de opleiding Farmacie in Groningen. Groningen: R.U., COWOG.

Domburg, M. van, Noordenbos, G., \& Portegijs, W. (1989). Loopbaanplanning: Een cursus voor vrouwen. Groningen: Wolters-Noordhoff. 
Doorne-Huiskes, J. van, \& Bedaux-de Jonge, M. (1983). Gezinssituaties en beroepsloopbanen van vrouwelijke artsen. Gezondheid' \& Samenleving, 4, 144- 153.

Doorne-Huiskes, J. van (1986). Loopbanen van vrouwen en mannen: een analyse. Utrecht: Rijksuniversiteit Utrecht.

Drop, M.J., \& Post, G.J. (1990). Perceptions and evaluations by graduates and faculty members of the Maastricht problem-based curriculum. In: Z.M. Nooman, H.G. Schmidt \& E.S. Ezzat (Eds.), Innovation in Medical Education: An evaluation of its present status (pp. 152-174). New York: Springer.

Duindam, V. (1995). Mannen, carrière en zorg: ambities en ambivalenties. Paper gepresenteerd tijdens het Symposium Ambigue Ambitie. Maastricht: Rijksuniversiteit Limburg.

Engelfriet, L.C., \& Veldr, M.C. van der (1994). Wie MN studeert voor werk? Onderzoek van Onderwijs, 23, 8-10.

Ettinger. M. van \& Asperen, R. van (1991). Solliciteren kun je leren: Een handleiding voor succesvol solliciteren. Rotterdam: AIESEC-Nederland.

Glebbeek, A.C. (1988). De arbeidsmarktpositie van opleidingen. Tijdschrift voor Arbeidsvraagstukken, 4, 75-89.

Greve, H. (1995). Anglisten op de arbeidsmarkt: Verslag van een onderzoek onder afgestudeerden van de opleiding Engelse Taal-en Letterkunde in Groningen. Groningen: Rijksuniversiteit Groningen, COWOG.

Gutek, B.A., \& Larwood, L. (1986). Women's Career Development. California: Sage.

Hall, D.T. (1971). A Theoretical Model of Career Subidentity Development in Organizational Settings. Organizational Behavior and Human Performance, 6, 50-76.

Hall, D.T. (1976). Careers in organizations. Santa Monica, California: Goodyear.

Harris-Bowlsbey, J., Spivack, J.D., \& Lisansky, R.S. (1986). Take hold of your future: A career planning guide. Towson, Maryland: ACT.

Heesink, J.A.M., \& Feij, J.A. (1992). Loopbaanontwikkeling en welzijn bij jongvolwassenen. Gedrag en Organisatie, 5, 343-365.

Heijke, J.A.M. (1990). De arbeidsmarkt voor universitaire studierichtingen. Tijdschrift voor Hoger Onderwijs, 8 (3).

Hermans, H.J.M. (1976). Prestatie Motivatie Test: Handleiding. Amsterdam: Swets \& Zeitlinger.

Hoekstra, H.A., \& Smeets, M.A.H.J. (1992). Waarderinsonderzoek en zelfmanagement bij heroriëntatie op de loopbaan. Gedrag en Organisatie, 5, 467-481.

Holahan, C.K., \& Gilbert, L.A. (1979). Interrole conflict for working women: careers versus jobs. Journal of Applied Psychology, 64, 86-90.

Hooff., J.J., \& Dronkers,J. (1980). Onderwijs en Arbeidsmarkt. Deventer: van LoghumSlaterus.

Janssen, P.P.M. (1992). Relatieve deprivatie in de middenloopbaanfase bij hoger opgeleide mannen: Een vergelijking tussen drie leeftijdsgroepen. Maastricht: Universitaire pers.

Jong, A.M. de (1983). Gelijke behandeling en het personeelsbeleid: De positie van de vrouw in de arbeidsorganisatie. Deventer: Kluwer.

Josefowitz, N., \& Gadon, H. (1988). Fitting in. How to get a good start in your new job. Reading, Massachusets: Addison-Wesley.

Kluytmans, F., \& Hancké, C. (1993). Leerboek personee/smanagement. Deventer: Kluwer Bedrijfswetenschappen.

Kok, G.J., Den Boer, D.J., De vries, H., Gerards, F., Hospers, H.J., \& Mudde, A.N. (1992). Self-efficacy, attributions and health. In: R. Schwarzer (Ed.), Self-efficacy: Thought control of action. Washington: Hemisphere.

Kolb, D.A. (1984). Experiential Learning: Experience as the source of Learning. Englewood Cliffs: New Jersey. 
Larwood, L., \& Gattiker, U.E. (1987). A comparison of the career paths used by successful women and men. in: B.A. Gutek \& L. Larwood (Ed). Women's Career Development. (pp. 129-156). California: Sage.

Latack, J.C. (1989). Work, stress and careers: a preventive approach to maintaining organizational health. In: M.B. Arthur, D.T. Hall \& B.S. Lawrence (Eds.) Handbook of career theory. (pp. 252-274). Cambridge: University Press.

Lievegoed, B. (1991). Managing the developing organisation. Oxford: Basil Blackwell Lodder, B.J.H., Loo, P.J.E., van de, Ramaekers, G.W.M. \& Velden, R.K.W. van (1991). Arbeidsmark tindicatoren ten behoeve van het emancipatiebeleid aan de Rijksuniversiteit Limburg. Maastricht: Rijksuniversiteit Limburg, ROA.

Lodder, B.J.H., Loo, P.J.E., van de, Ramaekers, G.W.M. \& Velden, R.K.W. van (1992). Sex differences in the labour market position of young graduates. In: Tj. Plomp, J.M. Pieters, \& A. Feteris (Eds.), European Conference on Educational Research: Book of summaries (pp. 1057-1059). Enschede: University of Twente.

Louis, M. Reis. (1980). Surprise and Sense Making: What newcomers experience in entering unfamiliar organizational settings. Administrative Science Quaterly, 25, 226-251.

Louis, M. Reis. (1980). Career Transitions: Varieties and Commonalities. Academy of Management Review, 5, 329-340.

Louis, M. Reis. (1982). Managing Career Transition: A missing link in career development. Organizational Dynamics. Amacom Periodicals Division.

Luteijn, F., Starren, J. \& Dijk, H. van (1985). Handleiding bij de Nederlandse Persoonlijkheidsvragenlijst, NPV. Lisse: Swets \& Zeilinger.

Maanen, J. van (1977). Organizational Careers: Some New Perspectives. Sloan School of Management, Massachusetts Institute of Technology.

Meesters, M.J. (1992). Loopbanen in het onderwijs en op de arbeidsmarkt. Verticale en horizontale differentiatie in het voortgezet onderwijs: oorzaken en gevolgen voor de arbeidsmark toositie van Nederlandse jongeren. Proefschrift, Universiteit van Amsterdam.

Mensink, J.C.M. (1994). Zelfmanagement in lerende organisaties. Deventer: Kluwer.

Miller, D.C., \& Form, W.H. (1964). Industrial sociology. New York: Harper \& Row.

Nicholson, N., \& West M.A. (1985). Future uncertain: Expected vs. attained job mobility among managers. Journal of Occupational Psychology, 58, 313-320.

Nicholson, N. (1987). Good and bad practices in graduate development. Personnel Management, 34-38.

Nicholson, N., \& West M.A. (1988). Managerial job change: men and women in transition. Cambridge: University press.

Nieuwenhuysen, W.L. van, \& Wielers, R.J.J. (1990). De arbeidsmarktpositie van intredende academici. Groningen: Rijksuniversiteit Groningen, RION.

Porter, L.W., Lawler, E.E., \& Hackman, J.R. (1975). Behavior in Organizations. New York: McGraw-Hill.

Ramaekers, G.W.M., \& Heijke J.A.M. (1991). Arbeidsmarktscanner Rijksuniversiteit Limburg, Afgestudeerden 1986 - 1989. Maastricht: Rijksuniversiteit Limburg, ROA.

Ramaekers, G.W.M. (1994). Arbeidsmarktscanner Rijksuniversiteit Limburg: Basismeting Cohort '92. Maastricht: Rijksuniversiteit Limburg, ROA.

Ramsden, P. (1992). Learning to teach in higher education. London, New York: Routledge.

Roe, R.A. (1990). Personeelsselectie: modellen en instrumenten. In: P.J. Drenth, Hk. Thierry, Ch.J. de Wolff (Red.). Nieuw Handboek Arbeids-en Organisatiepsychologie. Houten: Boon Stafleu \& Van Loghum.

Sanders, K. (1991). Vrouwelijke pioniers: Vrouwen en mannen met een 'mannelijke' hogere beroepsopleiding aan het begin van hun loopbaan. Amsterdam: Thesis.

Sanders, K., \& Doorne-Huiskes, J. van (1989). Methoden van zoeken en toekomstbeeld. Tijdschrift voor Arbeidsvraagstukken, 5 (4), 59-68. 
Schatulek. w. B. (1988), Opgebrand: Achtergronden van werkstress bij contactuele beroebess het bumoutsyndroom. Rotterdam: Donker.

Sohein, E.H. (1968). The First Job Dilemma. An appraisal of why college graduates change jobs and what can be done about it. Psychology today: a general magazine about the discolphines of psychology, 1, 27-37.

Schein. E.t. (1978). Career dynamics; matching individual and organizational needs. Massachusetts: Addison Wesley.

Schmidt. H.G. (1993). Foundations of problem-based learning: some explanary notes. Medical education, 27.

Schreurs, M.L.J.J., \& Pol, J.A.M. van de (1985). Loopbaanplanning: vooral voor vrouwen een noodzakelijk onderdeel van de academische opleiding. Gedrag: Tijdschrift voor Psychologie, 13, 47-60.

Scheurs, M.L.J.J. \& Kramer, C. (1988). Beroepsperspectief van gezondheidswetenschappers: Verslag van een enquête onder afgestudeerde gezondheidswetenschappers. Maastricht: Rijksuniversiteit Limburg.

Schreurs, M.L.J.J., \& Hommes, J.A. (1992). Arbeidsmarktoriëntatie en Solliciteren. Groningen: Wolters-Noordhoff.

Schuyt, Th.N.M. (1986). Wie wil er nog promoveren? Bilthoven: Pharos.

Schwarzer, R. (1992). Self-efficacy: Thought control of action. Washington: Hemisphere.

Spangenberg J.F.A., \& Nijhuis, F.J.N. (1990). Human information processing in science. Scientometrics, 18, 389-407.

Stoner, J.A.F. \& Freeman, R.M. (1992). Management. Engelewood Cliffs, N.J.: Prentice Hall.

Stuurman L.A.G.M. (1993). Gelijk niveau en toch...: Een onderzoek naar de verschillen in arbeidsmarktoriëntatie, zoekproces en functiekwaliteit van mannelijke en vrouwelijke alumni van de Katholieke Universiteit Brabant. Tilburg: KUB.

Super, D.E. (1957). The psychology of careers. New York: Harper \& Row.

Swanborn, P.G. (1984). Methoden van sociaal-wetenschappelijk onderzoek. Meppel: Boom.

Swieringa, J., \& Wierdsma, A.F.M. (1990). Op weg naar een lerende organisatie. Groningen: Wolters-Noordhoff.

Van de Loo, R.P.J.M. (1992). Verheldering van loopbaanperspectief. Assen, Maastricht: Van Gorcum.

Vander Meeren, W., Luyk, F. van, \& Peters, F. (1993). Selectiemiddelen: Predictoren. In: F. Kluytmans \& C. Hancké (Red.) Leerboek personeelsmanagement. Deventer: Kluwer.

Velden, R. van der (1990). Letterenstudenten op de arbeidsmarkt. Tijdschrift voor Hoger Onderwijs, 8, 123-128.

Vianen, A.E.M. van (1987). Het selectie interview. Leiden: Rijksuniversiteit.

Vianen, A.E.M. van, \& Keizer, W.A.J.. (1992). De ambitie van mannen en vrouwen voor een leidinggevende functie in traditioneel door mannen beheerste werkomgevingen. Geaiag en organisatie, 5, 382-402.

Wielers, R., \& Nieuwenhuysen W. van (1990). Determinanten van arbeidsmarktintrede van academici. Tijdschrift voor Hoger Onderwijs, 8, 115-121.

Willige, G. van de, Schreurs, P.. Tellegen, B., \& Zwart, F. (1985). Het meten van 'lifeevents': De vragenlijst Recent Meegemaakte Gebeurtenissen (VRMG). Nederlands Tijdschrift voor de Psychologie, 40, 1-19.

Wolff, Ch.J. de, \& Bosch, G. van den (1990). Het selectieproces. In: P.J. Drenth, Hk. Thierry, Ch.J. de Wolff (Red.), Nieuw Handboek Arbeids-en Organisatiepsychologie. Houten: Boon Stafleu \& Van Loghum. 


\section{Bijlage}

Tabel 1: Aantallen waarop de correlatiematrix in tabel 4.10 is gebaseerd

\begin{tabular}{lccccccccccc}
\hline & & & 2 & 3 & 4 & 5 & 6 & 7 & 8 & 9 & 10 \\
\cline { 2 - 10 } & & -- & 153 & 160 & 172 & 176 & 161 & 148 & 179 & 179 & 179 \\
1. werkervaring & & - & 138 & 149 & 153 & 138 & 130 & 155 & 155 & 155 \\
2. stage & & & -- & 155 & 159 & 149 & 149 & 162 & 162 & 162 \\
3. planmatig & & & -- & 172 & 156 & 144 & 174 & 174 & 174 \\
4. plannen & & & & - & 161 & 148 & 178 & 178 & 178 \\
5. self-efficacy & & & & & -- & 137 & 163 & 163 & 163 \\
6. prestatiegerichtheid & & & & & & -- & 150 & 150 & 150 \\
7. probleemoplossen & & & & & & & -- & 181 & 181 \\
8. leeftijd & & & & & & & & -- & 181 \\
9. studiejaar & & & & & & & & & & --
\end{tabular}

Tabel 2: Aantallen waarop de correlatiematrix in tabel 5.9 is gebaseerd

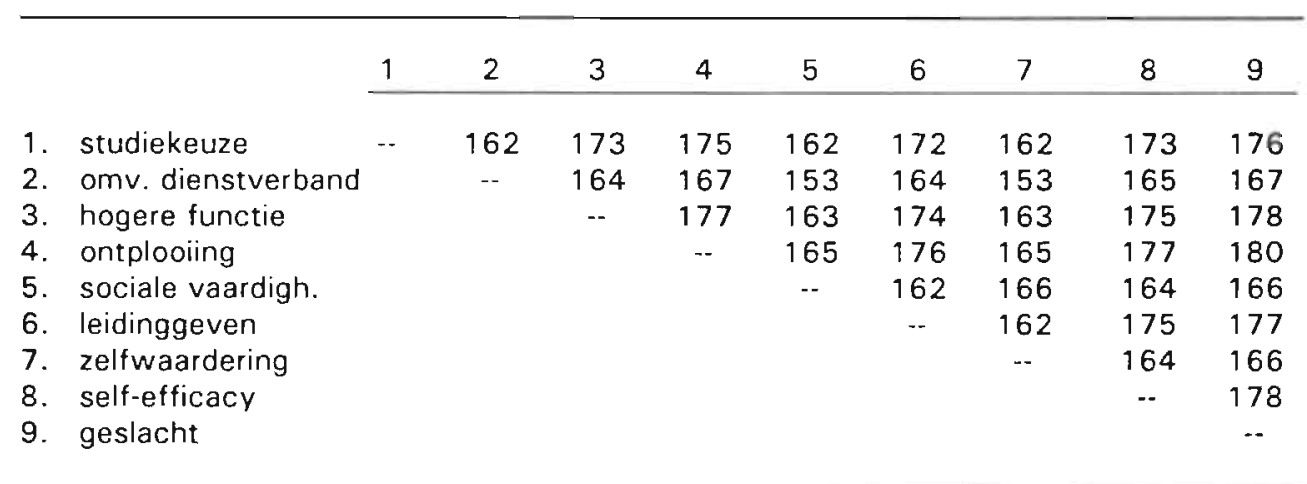


Tabel 3: Aantallen waarop de correlatiematrix in tabel 6.14 is gebaseerd

\begin{tabular}{|c|c|c|c|c|c|c|c|c|c|c|c|}
\hline & 1 & 2 & 3 & 4 & 5 & 6 & 7 & 8 & 9 & 10 & 11 \\
\hline 1. coping gedrag & .. & 31 & 32 & 30 & 22 & 27 & 30 & 34 & 34 & 32 & 34 \\
\hline 2. neg. ervaringen & & - & 31 & 29 & 22 & 26 & 29 & 33 & 33 & 31 & 33 \\
\hline 3. verrassingen & & & -. & 32 & 25 & 29 & 31 & 35 & 35 & 31 & 33 \\
\hline 4. sociale steun & & & & $\ldots$ & 23 & 29 & 30 & 33 & 33 & 31 & 33 \\
\hline 5. introductie & & & & & .. & 21 & 22 & 25 & 25 & 24 & 25 \\
\hline 6. feedback & & & & & & -- & 27 & 30 & 30 & 28 & 30 \\
\hline 7. rolverandering & & & & & & & .. & 33 & 33 & 31 & 33 \\
\hline 8. periode werkzaam & & & & & & & & $-\cdot$ & 37 & 35 & 37 \\
\hline 9. uitdaging & & & & & & & & & -. & 35 & 37 \\
\hline 10. functievoorkeur & & & & & & & & & & -- & 35 \\
\hline 11. geslacht & & & & & & & & & & & -- \\
\hline$l^{*} \mathrm{p} \leq .05, * * \mathrm{p} \leq .01$, & $* *$ & 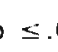 & & & & & & & & & \\
\hline
\end{tabular}

Tabel 4: Aantallen waarop de correlatiematrix in tabel 7.8 is gebaseerd

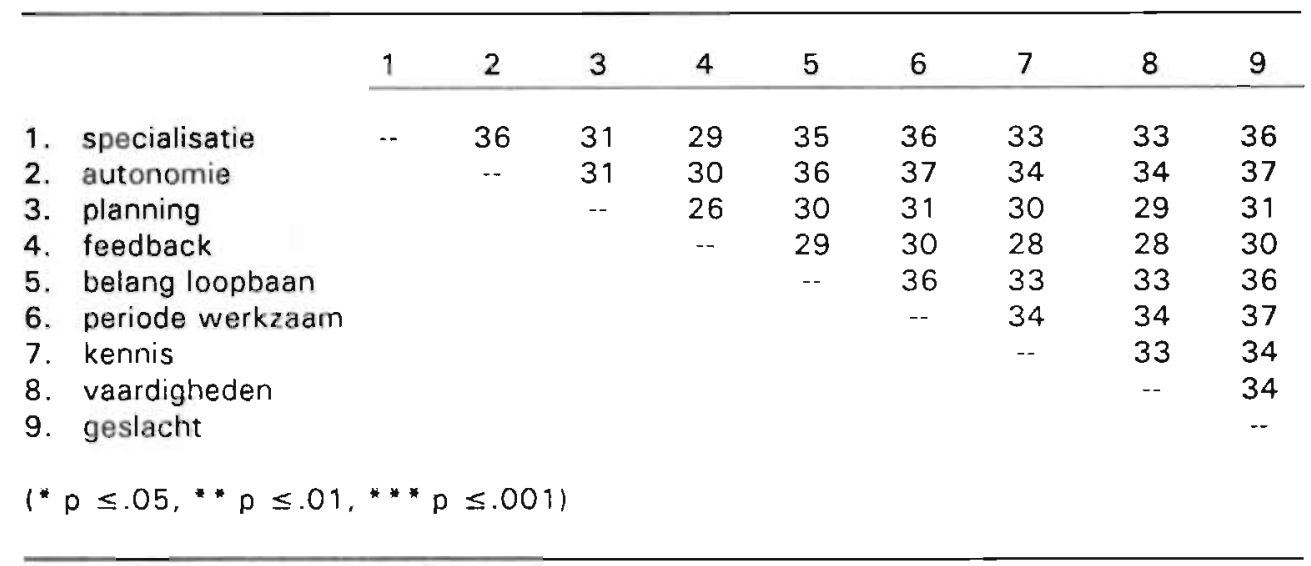




\section{Curriculum vitae}

Marie-Louise Schreurs werd geboren op 4 mei 1956 in Beegden. In 1974 behaalde zij haar Atheneum-B diploma aan het st. Ursula Lyceum te Roermond. In dat jaar startte zij met de studie psychologie te Nijmegen. Tijdens de doctoraalfase van de studie werkte zij gedurende enkele jaren als student-assistente bij de vakgroep Arbeids- en organisatiepsychologie ten behoeve van het praktikum Algemene Beroepsvaardigheden. In februari 1983 behaalde zij haar doctoraaldiploma met als hoofdrichting klinische psychologie en als uitbreiding psychologie van arbeid en organisatie.

In 1983 en 1984 was zij als wetenschappelijk medewerker verbonden aan de vakgroep Arbeids- en organisatiepsychologie.

Eind 1984 trad zij in dienst bij de Faculteit der Gezondheidswetenschappen van de Rijksuniversiteit Limburg, (RL). Als medewerker van het Skillslab werkte zij aan de ontwikkeling van trainingen op het gebied van studie- en beroepsvaardigheden.

Van 1985 tot 1988 was zij voorzitter van de Vrouwenemancipatiecommissie van de RL.

Vanaf 1989 is zij als universitair docent verbonden aan de vakgroep Onderwijsontwikkeling en Onderwijsresearch, met als belangrijkste aandachtsgebied de coördinatie en ontwikkeling van het vaardigheidsonderwijs. Het onderzoeksproject naar het overgangsproces van de opleiding naar de arbeidsmarkt is in dat jaar gestart.

Zij is bestuurslid van de sectie Training en Opleiding van het Nederlands Instituut van Psychologen (NIP). Verder is zij geregistreerd als gedragswetenschappelijk opgeleide trainer bij het NIP. 
Carrière-ontwikkeling:

de overgang van opleiding naar arbeidsmarkt

Marie-Louise Schreurs

In dit proefschrift is het overgangsproces van de opleiding naar de arbeidsmarkt onderzocht. Dit proces vormt een cruciale fase in de carrière-ontwikkeling. waarvas het belang meestal niet wordt onderkend.

In een longitudinaal onderzoek bij studenten en 'afgestudeerden van de Faculteit der Gezondheidswetenschappen van de Rijksuniversiteit Limburg is nagegaan, welke factoren van invloed zijn op een succesvolle overgang van de opleiding naar de arbeidsmarkt. In totaal zijn vier deel-onderzoeken verricht. Het overgangsproces is opgesplitst in vier opeenvolgende, fases: de voorbereiding, de fase van baă verwerven, de eerste werkervaringen en de fase van het ervaren van succes in het werk. Daarnaast wordt specifiek aandacht geschonken aan de rol van de opleiding in de overgang van opleiding naar arbeidsmarkt.

Uit het onderzoek komt naar voren dat dofelgerichtheid en prestatiegerichtheid met name van belang zijn in de voorberelfingstase. In de fase van baan verwerven zijn de motivatie en vertrouweh in eigen kwaliteiten essentieel. Omgevingsfactoren blijken cruciaal in de fase vari de eerste werkervaringen, zoals de introduktieperiode en het krijgen van yoede bedback en ondersteuning. Bij het ervaren van succes blijken de eigen capa sitejten essemlipel.

Verschillen tussen mannen en vrouwen komen in de opu vifvolgende fases naar voren. Het lijkt erop dat de vrouwen die deel uitmaken van deze stujle, een geschikte werkstijı hebben ontwikkeld, maar geneigd zijn het afstuderen enige tijd uit te stellen. In de fase van baan verwerven blijkt dat vrouwelvgh studenten vaker van plan zijh in deeltijd te werken en een lager zelfvertrouwèr hebben met betrekking tot het bereiken van de gewenste baan. In de tasé var de eerste werkervaringen rapporteren vrouwen naar verhouding vaker negalieve ervaringen; mannen noemen meer positieve ervaringen. Het lijkt alsof de overstap naar de arbeidsmarkt voor vrouwen minder vanzelfsprekend is dent voor mannen.

Marie-Louise Schreurs is als universitair docent verbonden aan de vakgroep Onderwijsontwikkeling en onderwijsresearch van de Rijksuniversiteit Limburg. 